\title{
A BICICLETA NAS VIAGENS COTIDIANAS DO MUNICÍPIO DE SÃO PAULO
}

EXEMPLAR REVISADO E ALTERADO EM RELAÇÃO À VERSÃO ORIGINAL, SOB RESPONSABILIDADE DO AUTOR E ANUÊNCIA DO ORIENTADOR.

O original se encontra disponível na sede do programa

São Paulo 22 de MAIO de 2014

MARIA ERMELINA BROSCH MALATESTA

SÃO PAULO

2014

UNIVERSIDADE DE SÃO PAULO

FACULDADE DE ARQUITETURA E URBANISMO 


\section{A BICICLETA NAS VIAGENS COTIDIANAS DO MUNICÍPIO DE SÃO PAULO}

Tese apresentada à Faculdade de Arquitetura e Urbanismo da Universidade de São Paulo para obtenção do título de Doutor

Área de Concentração: Planejamento Urbano e Regional

Orientador: Prof ${ }^{a}$. Dr ${ }^{\mathrm{a}}$. Klara Kaiser Mori

SÃO PAULO

2013

Autorizo a reprodução e divulgação total ou parcial deste trabalho por qualquer meio convencional ou eletrônico, com a finalidade de estudo e pesquisa, desde que citada a fonte. 


\section{FOLHA DE APROVAÇÃO}

Malatesta, Maria Ermelina Brosch. A Bicicleta nas viagens cotidianas do Município de São Paulo.

Tese de doutorado apresentada à Faculdade de Arquitetura e Urbanismo da Universidade de São Paulo para obtenção do título de Doutor.

Área de Concentração: Planejamento Urbano e Regional

Orientador: Prof ${ }^{\mathrm{a}}$. Dr ${ }^{\mathrm{a}}$ Klara Kaiser Mori

Aprovada em

Banca Examinadora:

Prof $^{\circ} \mathrm{Dr}^{\circ}$

Instituição Assinatura

Prof $^{\circ} \mathrm{Dr}^{\circ}$

Instituição Assinatura

Prof $^{\circ} \mathrm{Dr}^{\circ}$ Instituição Assinatura

$\operatorname{Prof}^{\circ} \mathrm{Dr}^{\circ}$ Instituição Assinatura

Prof $^{\circ} \mathrm{Dr}^{\circ}$

Instituição Assinatura 
Aos paulistanos que não utilizam automóveis em seus deslocamentos cotidianos. 


\section{AGRADECIMENTOS}

Quero agradecer primeiramente à minha orientadora Prof ${ }^{a} \mathrm{Dr}^{a}$ Klara Kaiser por ter acreditado no meu projeto de pesquisa e me aceito como orientanda. Pacientemente me conduziu e reconduziu várias vezes para o foco do trabalho.

Meus agradecimentos se estendem ao Prof ${ }^{\circ} \operatorname{Dr}$ Csaba Deák, que da banca do mestrado, foi quem inicialmente me aconselhou a fazer o doutorado e, durante esta etapa, pelas disciplinas cursadas, ampliou meus horizontes de conhecimento e reflexão sobre tema de minha pesquisa.

Agradeço também à $\operatorname{Prof}^{a}$ Dr $^{a}$ Silvana Zioni, amiga e incentivadora deste trabalho, através do estímulo resultante das nossas conversas, além das preciosas sugestões e indicações bibliográficas .

Não posso deixar de agradecer ao Engenheiro e Sociólogo Dr. Eduardo de Alcântara Vasconcellos, pela boa vontade em colaborar através de seus valiosos dados gentilmente cedidos e que complementaram pesquisas e bibliografia.

Incluo também nos meus agradecimentos os cicloativistas André Pasqualini, Arturo Alcorta, Miguel Roberson, Thiago Benícchio, Wilian Cruz pelas informações e autorização de uso das mesmas neste trabalho.

Meus agradecimentos incluem a CET - Companhia de Engenharia de Tráfego de São Paulo, empresa onde trabalhei por 35 anos e na qual desenvolvi e acumulei de todo conhecimento e experiência profissional na área de Trânsito $e$ Transporte, particularmente em Transporte Não Motorizado. Deixo registrada a minha gratidão e respeito ao corpo técnico com o qual convivi nestes anos todos por vários motivos: pela confiança, pelos desafios diários de levar em frente sonhos de melhorar a vida da cidade, pelo apoio recebido e pela calorosa amizade. De meus superiores o estímulo e a confiança. Junto a estes agradecimentos destaco em especial duas colegas que particularmente me 
ajudaram com a confecção de gráficos e imagens utilizadas neste trabalho: Glaucia Guimarães Pereira e Raquel Lourenço Novis.

Concluo meus agradecimentos registrando meu carinho ao meu filho e melhor amigo Pedro Malatesta Procópio de Araujo, que além de ter me ajudado a traduzir o abstract, foi a pessoa que mais me incentivou a prosseguir na minha tardia fase vida acadêmica, ao me convencer que meus escritos e estudos poderiam contribuir para melhorar a vida das pessoas. 


\section{RESUMO}

O fenômeno do recente crescimento do uso da bicicleta no Município de São Paulo, cidade não propriamente amigável à sua utilização, merece uma reflexão cuidadosa, baseada na análise detalhada dos motivos que realmente induziram esta situação. É importante que a avaliação destes fatos não induza a crer que sejam seus únicos e principais motivos o atual momento de consciência sobre a necessidade de preservação do meio ambiente e a valorização de políticas que envolvam o conceito de independência de utilização de recursos naturais.

No caso paulistano, a bicicleta tem sido uma saída espontânea encontrada por um setor específico da população, como tentativa de contornar a crônica má qualidade presente na mobilidade cotidiana da cidade, decorrência direta da deficiência dos serviços de transporte público existentes.

Pode-se afirmar que a constatação do aumento de uso da bicicleta em São Paulo tem sensibilizado o poder público e a sociedade, induzindo à realização de ações para seu estímulo e consolidação. Assim estão em alta como políticas públicas de transporte sustentando sua viabilidade, experiências consolidadas e bem sucedidas de muitas metrópoles no mundo, onde já se afirmou como uma boa opção de mobilidade.

Entretanto esta visão poderia se tornar equivocada e comprometer o atendimento ao que é realmente necessário para uma metrópole como São Paulo, se não for precedida ou acoplada à reestruturação de todo o sistema de transportes públicos paulistanos, de forma a promover o salto de qualidade e de eficiência exigidos. Neste processo o papel da mobilidade cicloviária é muito importante e poderá ser consolidado como elemento agregador desde que respeitadas e bem exploradas suas características.

Palavras- chave: Bicicleta; Infaestrutura Cicloviária; Transporte Não Motorizado; Políticas Públicas de Transporte Cicloviário; Planejamento Cicloviário; Legislação Cicloviária do Brasil e do Município de São Paulo. 


\section{ABSTRACT}

The phenomenon of the recent growth on the bicycle usage in the city of São Paulo, which actually is not friendly to its use, deserves a thorough reflection, based on the detailed analysis of the reasons which induced such situation. It is important that the evaluation of these facts do not lead us to believe that the only and main reasons are the current scenario of the consciousness on the environment preservation and appreciation of policies which involve the concept of independence of natural resources usage.

As for São Paulo case, the bicycle has been a spontaneous solution found by a specific population sector, as an attempt to get around the chronic low quality existing in the city's daily mobility, direct outcome of the deficiency in the current public transport services. This deficiency is the result of successive and misguided policies of mobility.

It is possible to claim that the increase in the bicycle use in São Paulo has sensitized the public power and the society inducing to the completion of actions in order to stimulate and consolidate it. Therefore these actions are now the spotlight among the public policies of transport, supporting its viability from consolidated and successful experiences in many metropolis of the world, where the bicycle use has already been identified as a good mobility option.

However this view could become misguided, compromising the commitment to what is really necessary to a city like Sao Paulo, if it is not preceded or coupled to the restructuring of the whole Sao Paulo public transport system, in order to trigger the required quality and efficiency improvement. In this proccess the role of the bicycle mobility is very important and may be consolidated as the gathering element, taking into consideration that its characteristics are respected and well explored.

\section{Key-words:}

Bicycle; Cycling infraestructure; Non Motorized Tranport; Public Policy for Cycling; Bicycle Planning; Brazil and São Paulo City Bicycle Legislation 


\section{SUMÁRIO}

\section{CAPÍTULO 1. INTRODUÇÃO}

1.1. Considerações iniciais e apresentação do trabalho 15

1.2. A bicicleta e o espaço urbano paulistano 20

1.3. Contextualização do processo de produção das viagens de bicicleta em São Paulo no universo das viagens cotidianas

1.4. Objeto, objetivo e hipótese

\section{CAPÍTULO 2. CARACTERIZAÇÃO DAS VIAGENS DE BICICLETA NA REGIÃO} METROPOLITANA DE SÃO PAULO

2. Caracterização das viagens de bicicleta na Região Metropolitana de São Paulo

2.1. A representatividade das viagens de bicicleta na mobilidade da Região Metropolitana de São Paulo

2.2. A distribuiçãa das viagens de bicicleta entre os municípios que compõem

a Região Metropolitana de São Paulo

2.3. Dados complementares sobre as viagens de bicicleta da Região Metropolitana de São Paulo

\section{CAPÍTULO 3. A BICICLETA NO MUNICÍPIO DE SÃO PAULO: O VEÍCULO, O USUÁRIO}

\section{E SEU CONTEXTO URBANO}

3. A bicicleta no município de São Paulo: o veículo, o usuário e seu contexto Urbano

3.1.A Bicicleta: o veículo e seu processo de apropriação do espaço público paulistano

3.2. As viagens de bicicleta no Município de São Paulo

3.2.1. Representatividade

3.2.2. Integração da bicicleta a outros modos de transporte 
3.2.4. Caracterização das viagens externas às zonas de origem 54

3.2.5. Extensão das viagens de bicicleta 57

3.2.6. Duração das viagens de bicicleta 59

3.2.7. Motivos das viagens de bicicleta 59

3.2.8. Razões da opção do uso da bicicleta 61

3.2.9. A bicicleta de carga e o bicifrete 62

3.3. Os usuários da bicicleta - perfil sócio econômico 64

3.3.1. Gênero do ciclista cotidiano 64

3.3.2. Faixa etária do ciclista cotidiano 65

3.3.3. Faixa de renda do usuário da bicicleta 65

3.4. A vulnerabilidade do ciclista e sua representatividade nos acidentes de $\begin{array}{ll}\text { Trânsito } & 67\end{array}$

3.4.1. Veículos envolvidos nos acidentes com ciclistas 69

3.4.2. Faixa etária dos ciclistas vítimas de acidentes fatais $\quad 70$

3.4.3. Gênero das vítimas de acidentes fatais $\quad 71$

CAPÍTULO 4. LEGISLAÇÃO CICLOVIÁRIA, PROGRAMAS CICLOVIÁRIOS MUNICIPAIS E A PARTICIPAÇÃO DA SOCIEDADE

4. Legislação cicloviária, programas cicloviários municipais e a participação da sociedade $\quad 73$

4.1.Legislação

4.1.1. Uma visão geral da legislação 75

4.1.2. Lei Federal 9.503/97: CTB- Código de Trânsito Brasileiro 77

4.1.3. Lei Federal 12.587/12 - Lei Nacional da Mobilidade Urbana 79

4.1.4. Legislação Estadual $\quad 79$

4.1.5. Legislação Municipal $\quad 80$

4.1.5.1. Lei Municipal 10.907/90 - Ciclovias em novas avenidas 81

4.1.5.2. Lei Municipal 13.430/02 - Plano Diretor 81

4.1.5.3. Lei Municipal 14.266/07 - Sistema Cicloviário de São Paulo 82

4.1.5.4.Lei Municipal 15.649 / 12 - Vagas para bicicletas em pólos geradores 83 
4.2. Histórico dos Planos e Projetos Cicloviários na PMSP: desde os primeiros em 1980 até os dias atuais

4.2.1. Diretrizes do governo federal e a crise do petróleo

4.2.2. Anos 90: políticas ambientais e o reconhecimento da bicicleta no CTB

4.2.3. A primeira década de 2000 e a efetivação da política do transporte por Bicicleta no Município de São Paulo

4.2.4. A década atual e a coordenação do programa cicloviário pela Secretaria Municipal de Transportes

4.2.5.Tendências futuras da política cicloviária

4.3. Cicloativismo e cicloativistas: formadores de opinião e indutores de políticas e negócios

4.3.1. As origens do movimento cicloativista no Brasil e em São Paulo

4.3.2. Massa crítica / Bicicletada e o cicloativismo contemporâneo

4.3.3. O cicloativismo mercadológico como indutor de negócios, empresas

e parcerias poder público e iniciativa privada

4.3.4. A Ascobike e o bicicletário de Mauá: um caso de cicloativismo

Espontâneo

4.3.5. O cicloativismo e seu reflexo nas políticas cicloviárias paulistanas

\section{CAPÍTULO 5. AS INFRAESTRUTURAS CICLOVIÁRIAS EXISTENTES NO MUNICÍPIO DE SÃO PAULO}

5. As infraestruturas cicloviárias existentes no município de São Paulo

5.1. Situação atual da infraestrutura cicloviária do Município de São Paulo (referência março 2013)

5.2. Ciclovia da Adutora Rio Claro ou Parque da Integração Zilda Arns:

registro de intervenção de má qualidade

5.3. Bicicletários e a integração modal aos sistemas de transporte

5.4. Bicicletas públicas: bikesharing ou bicicletas compartilhadas

5.4.1. Bicicletas do Metrô

5.4.2. Sistema Bikesampa 
5.5. Ciclofaixas de lazer - uma invenção paulistana

CAPÍTULO 6 . INFRAESTRUTURA E PROGRAMAS CICLOVIÁRIOS PREVISTOS PARA 0 MUNICÍPIO DE SÃO PAULO

6. Infraestrutura e programas cicloviários previstos para o município de São Paulo

6.1. Infraestrutura de circulação cicloviária proposta

6.2. Programa de bicicletas públicas integradas à rede de corredores de Ônibus

6.3. Curso Pedalar com Segurança

CAPÍTULO 7 - CONCLUSÕES

CAPÍTULO 8 - PÓSFACIO

\section{ANEXO I - LEGISLAÇÃO CICLOVIÁRIA}

1. Legislação Federal

2. Legislação Estadual

3. Legislação Municipal

\section{ANEXO II - CICLOATIVISMO}

1. ONG Vádebike

2. ONG Bicicreteiro

3. ONG Bikeanjo

4. ONG Ciclocidade

5. Site Escola de Bicicleta

6. Rede social Facebook 


\section{ANEXO III - DETALHES DA INFRAESTRUTURA CICLOVIÁRIA EXISTENTE}

1. Parque Zilda Arns

2. Tabela de vagas dos bicicletários

3. Programas de integração modal com a rede metroferroviária

\section{REFERÊNCIAS BIBLIOGRAFICAS}

Livros, relatórios e documentos técnicos

Mídia impressa e eletrônica

Internet: sites, blogs e redes sociais 
CAPÍTULO 1

INTRODUÇÃO 


\section{INTRODUÇÃO}

\subsection{Considerações iniciais e apresentação do trabalho}

O Município de São Paulo, não é propriamente uma cidade estimulante e amigável ao uso da bicicleta como forma de transporte diário: seu sistema viário intensamente ocupado e priorizado para o tráfego motorizado é assentado em relevo topograficamente acidentado, com clima instável e de grande amplitude térmica. Além disso, por fatores culturais, a bicicleta nunca foi uma forma de deslocamento representativa na cidade: antes do processo de intensificação do uso diário do automóvel, a mobilidade paulistana era calcada, sobretudo, por alternativas de transporte coletivo: linhas de bondes posteriormente cedendo lugar aos ônibus, e este processo todo aliado ao transporte a pé.

Entretanto, na recente década, tem sido constatada a intensificação do número de viagens utilitárias de bicicleta, ao ponto deste tipo de transporte passar a ser incluído, desde 1997, na Pesquisa de Origem e Destino do Metrô da Região Metropolitana de São Paulo, a única pesquisa de transporte atualmente disponível, que passou a ser realizada a cada dez anos, desde 1967. Mesmo representando um porcentual muito pequeno da matriz modal metropolitana e municipal $(0,8 \%$ e $0,6 \%$ respectivamente), este porcentual praticamente triplicou (aumento de 187\%) na Região Metropolitana de São Paulo e duplicou (pouco mais de 100\%) no Município de São Paulo entre 1998 e 2007.

Uma análise mais detalhada deste fenômeno, certamente tem por trás de si uma forte motivação decorrente da própria situação da estruturação, ou melhor dizendo, desestruturação da mobilidade paulistana, decorrente da crônica e generalizada situação de desequilíbrio entre a oferta de infraestrutura de transporte e a demanda cotidiana por viagens.

Esta situação, resultado de sistemáticas políticas públicas elitizadas com enfoque ao deslocamento motorizado individual, minimizou a importância do transporte coletivo na estruturação da mobilidade cotidiana paulistana e postergou, sucessivamente, a construção de uma rede de transportes públicos 
compatível ao processo de metropolização do município. Colaborou assim para criação de um cenário que prima pela perda de qualidade de vida da população que se vê presa, 27 dias por ano, em congestionamentos de trânsito: “ Em 2009, o recorde de índice de congestionamento em São Paulo - $294 \mathrm{~km}$ de lentidão - foi quebrado duas vezes no mesmo dia. Ao longo da última década, $118 \mathrm{~km}$ de vias congestionadas têm sido a média diária da cidade nos horários de pico. Entre os anos 2000 e 2008, a velocidade média do trânsito nos horários de pico da manhã e da tarde na cidade de São Paulo foi de 19,30 km/h." 1 Complementando estas informações, dados do IPEA apontaram que o tempo médio de deslocamento casa-trabalho no município de São Paulo foi de 42 minutos em $2009^{2}$.

Assim, o usuário do transporte público sempre está em busca de saída para as péssimas condições de serviço ofertadas por metrô, trens e ônibus superlotados, estes últimos com itinerários e articulações desorganizados, e altas tarifas. Por sua vez o usuário do automóvel tenta se livrar dos crônicos congestionamentos cada vez mais extensos e duradouros que já extrapolam os $300 \mathrm{Km}$ de extensão: "A cidade de São Paulo bateu ontem seu recorde histórico de congestionamento - com $300 \mathrm{~km}$ de filas rastreados pela CET (Companhia de Engenharia de Tráfego)...quase $35 \%$ de todas as vias monitoradas pela companhia ficaram travadas" 3 .

Uma alternativa muito buscada, a bicicleta, mesmo com desvantagens representadas pela fragilidade, insegurança e desconforto, tem compensações sob o enfoque econômico, ambiental e saúde, fundamentais para quem não aceita os sacrifícios impostos pelo uso diário do transporte público ou do automóvel.

Muitos optam pela bicicleta por não terem condições de possuir um veículo individual motorizado, ainda idealizado por muitos como o melhor modo para viajar. Mas neste processo de busca de alternativas, vislumbram na bicicleta uma forma de economizar tempo e dinheiro e acabam descobrindo,

\footnotetext{
${ }^{1}$ Rolnik e Klintowikz - Mobilidade na cidade de São Paulo / Dossiê São Paulo Hoje - 2011

2 IPEA (Pereira e Shwanen) - "Tempo de deslocamento casa-trabalho no Brasil (1992-2009): diferenças entre Regiões Metropolitanas, Níveis de Renda e Sexo" - 2013

${ }^{3}$ Folha de São Paulo: "São Paulo tem o maior trânsito da história" - Caderno Cotidiano - 27/07/13
} 
posteriormente, os benefícios trazidos à saúde pela prática da atividade física e o prazer em pedalar.

Da mesma forma, para a parcela que migra do transporte individual motorizado, a bicicleta oferece, além da redução do tempo de viagem e da economia de custos, um modo de transporte vinculado à liberdade: o condutor é liberado da obrigatoriedade de atendimento às legislações de trânsito, incluindo-se aí a necessidade de habilitação, não paga multas de trânsito e tão pouco taxas e impostos vinculados ao direito de circular (à bicicleta incide somente o imposto relativo à sua produção). Também eles descobrem o prazer proporcionado pelo desfrute do ambiente urbano, impossibilitado pelo isolamento imposto pelo automóvel.

Por outro lado, o fenômeno do crescimento dos deslocamentos paulistanos por bicicleta ocorre concomitantemente à sensibilização da consciência mundial para a causa do meio ambiente e da sustentabilidade nas grandes cidades. Esta ideologia elege a bicicleta como o modo de transporte individual mais limpo e econômico e, portanto o mais adequado para elas. Como consequência exerce grande influência para o desenvolvimento de políticas públicas voltadas para transformações urbanas necessárias à inserção da circulação ciclística nas redes de fluxos urbanos, de forma a consolidá-la como veículo cotidiano.

Neste cenário, o caso paulistano de registro do crescimento da mobilidade ciclística não deve se encaixar, conveniente e equivocadamente, como única e melhor alternativa às necessárias de urgentes ações para a reestruturação de rede dos sistemas de transporte de massa. Ele deve sim servir de alerta para a situação de extrema precariedade dos serviços de transporte público e para a necessidade de urgência na implementação de políticas que definitivamente revertam esta situação.

Assim cabe apontar ao poder público e à sociedade que, sem haver solução para os atuais problemas estruturais das redes de transporte, dotar a cidade de infraestrutura cicloviária como única saída e alternativa, é certamente querer comprometer o verdadeira papel da bicicleta como transporte na matriz da mobilidade cotidiana do município. 
A partir destas considerações desenvolveu-se a presente tese, calcada em pesquisas e reflexões sobre a significância do Transporte Cicloviário na realidade das viagens cotidianas paulistanas, considerando também o contexto da Região Metropolitana. Nela ainda se inclui o enfoque histórico do assunto como política e opinião pública no processo de inserção da viagem de bicicleta na realidade urbana atual e futura da cidade.

Tendo em vista a contemporaneidade do tema, que certamente implica na necessidade de continuidade do processo de pesquisa, reflexão e análise, estabeleceu-se como data limite para a exposição de fatos neste trabalho o primeiro semestre do ano de 2013.

O trabalho é desenvolvido em 6 (seis) capítulos a saber:

Capítulo 1 - Tece considerações sobre o papel da viagem de bicicleta na Matriz das Viagens Paulistanas refletindo sobre as atuais condições e os fatores que motivaram a busca da bicicleta como modo de transporte cotidiano. Também justifica a viagem de bicicleta como objeto deste trabalho.

Capítulo 2 - Expõe e analisa a representatividade das viagens de bicicleta na mobilidade da Região Metropolitana de São Paulo e detalha suas características.

Capítulo 3 - Apresenta a significância da viagem de bicicleta no Município de São Paulo, seu processo de apropriação do espaço público e o perfil destas viagens.

Capítulo 4 - Detalha o aparato legal e institucional sobre o qual se desenvolvem as ações políticas voltadas à viabilização e ao estímulo ao uso da bicicleta no cotidiano da mobilidade do município, inserido no universo da legislação federal, estadual e municipal. Aborda a ação política da opinião pública e da sociedade civil através do cicloativismo, assim como as iniciativas do capital privado pelo potencial mercadológico representado pela imagem simpática, moderna e benéfica da bicicleta.

Capítulo 5 - Aborda a atual situação da infraestrutura cicloviária no Município de São Paulo em seu repertório de sistemas onde ocorre a circulação, estacionamento, integração modal e compartilhamento de bicicletas. Expõe o papel desta infraestrutura como ação resultante das iniciativas do poder público 
municipal e metropolitano, além das ações políticas concomitantes vinculadas à fiscalização e educação de trânsito que acompanham a inserção da bicicleta no universo dos usuários do sistema viário urbano.

Capítulo 6- Expõe os programas de dotação de infraestrutura cicloviária para a cidade previstos para os próximos anos pela Prefeitura de São Paulo.

Capítulo 7 - Apresenta as conclusões sobre a significância do transporte cicloviário na mobilidade paulistana a partir dos dados apresentados e analisados, complementados com as ações necessárias para garantir ao transporte cicloviário seu legítimo papel na matriz dos deslocamentos cotidianos do Município de São Paulo.

Capítulo 8 - Constituído por um pósfacio elaborado após a defesa com considerações complementares derivadas das colocações realizadas pelos membros da banca.

Finalmente cabe ressaltar que a contemporaneidade do tema escolhido para este trabalho não permitiu uma ampla disponibilidade de referências bibliográficas em relação a títulos acadêmicos ou de literatura técnica especializada com abordagem especifica sobre o registro ou a gestão do cotidiano do transporte cicloviário em São Paulo. Entretanto esta deficiência foi suprida pela experiência profissional de três décadas trabalhados na CET Companhia de Engenharia de Tráfego de São Paulo, com atuação focada na área de Transporte Não Motorizado: a Pé e Bicicleta . Esta experiência possibilitou acumular conhecimento, material técnico e vivência pessoal, através de fatos, testemunhos e opiniões que certamente foram válidos para embasar o desenvolvimento da presente tese. 


\subsection{A bicicleta e o espaço urbano paulistano}

Malucos, atletas, excêntricos, pobres, exibicionistas, idealistas, ecochatos, talibikers ${ }^{4}$, empecilhos, indisciplinados. Muitas são as qualificações atribuídas aos que insistem em ocupar diariamente o concorrido espaço urbano das ruas paulistanas pedalando. Espremidos pelo tráfego motorizado ou intrusos nas calçadas, parece que nas ruas de São Paulo não há lugar para quem queira conduzir uma bicicleta. Apesar de ser definida como veículo pela legislação federal - Código de Trânsito Brasileiro - a bicicleta continua sendo entendida pela maioria como brinquedo, equipamento esportivo e de lazer. Assim muitos acreditam que seu lugar não é nas ruas, mas sim em parques, beira de praia ou pistas de competição.

Entretanto a bicicleta, concebida desde a época de Leonardo da Vinci e aperfeiçoada com as características atuais, concomitantemente ao surgimento do automóvel, foi consagrada como forma usual de transporte em muitas cidades europeias desde que a sua fabricação se popularizou. Atualmente está presente na matriz modal de viagens em cidades no mundo todo com um porcentual significativo, como é o caso emblemático de Amsterdã com praticamente $40 \%{ }^{5}$ de suas viagens diárias realizadas por bicicleta.

Mas São Paulo não é Amsterdã e nem foi colonizada por holandeses. Assim as viagens paulistanas, que antigamente eram feitas a pé e principalmente por transporte público, migraram em grande parte para o automóvel. Hoje em dia, estas três modalidades praticamente dividem entre si a maioria dos deslocamentos diários. Todavia nos últimos dez anos tem se presenciado um aumento considerável das viagens de bicicleta, atingindo índices de quase 200\% de acréscimo entre 1997 e 2007, segundo a última Pesquisa de Origem e Destino do Metrô (2007).

Mesmo representando uma pequena parcela do total das viagens realizadas diariamente na cidade, como já mencionado anteriormente, não deixa de retratar um fenômeno que merece olhar atento para tentar descobrir e

\footnotetext{
"Gancia, Barbara - "A burca do talibiker!" Crônica - Revista da Folha de SP - 22 a 28/08/2010

${ }^{5}$ Informação fornecida pela Embaixada Holandesa de Ciclismo durante visita em SP - maio 2013
} 
entender suas causas e sua influência na matriz geral das viagens paulistanas. 0 maior motivo para isto é o seu significado como uma espontânea reação geral à má qualidade do deslocamento cotidiano da cidade gerada pela falta de investimento na estruturação de uma rede de transporte público compatível à demanda como metrópole.

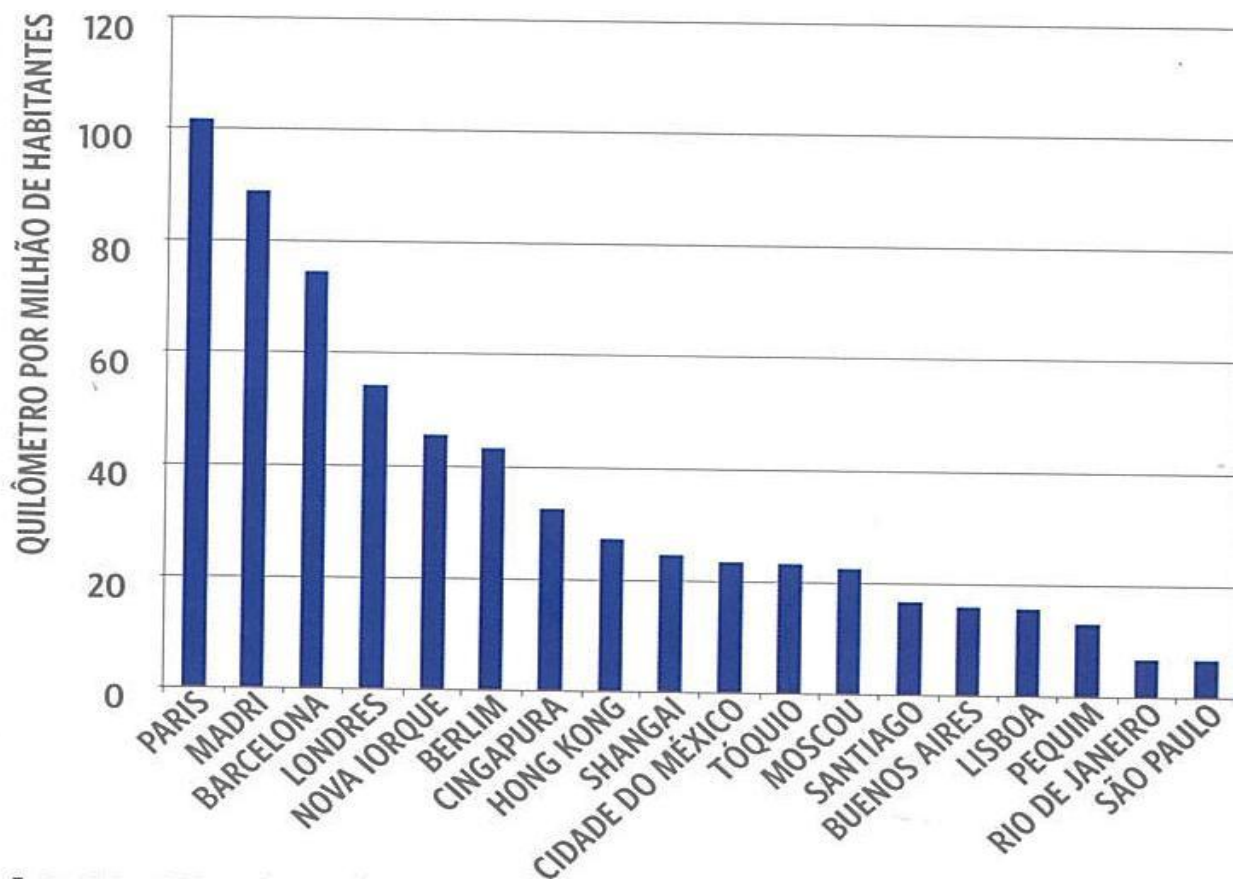

Gráfico 1- Índice de cobertura de redes de metrô selecionadas, Município de São Paulo $2010^{6}$ - Km por milhão de habitantes

Fonte: Metrô database. In: metrobits.org

o Gráfico 1 comprova o quão pouco São Paulo é atendida por rede estrutural de transporte, comparada a outras metrópoles como Paris, Londres, Nova lorque e Berlim. Nestas cidades, as políticas praticadas para estimular o uso da bicicleta como meio de transporte, consideram sua utilização a partir de suas reais possibilidades, respeitando a escala da bicicleta na estruturação da sua mobilidade, sem idealizar e impor a bicicleta como solução única para todos os tipos de deslocamentos.

Outro aspecto que merece destaque são os movimentos espontâneos da sociedade em favor da bicicleta, conhecidos como movimentos cicloativistas. Embora exercidos por uma minoria, tem o poder de articulação e mobilização

\footnotetext{
${ }^{6}$ Prefeitura do Município de São Paulo / Secretaria Municipal do Desenvolvimento Urbano “SP 2040: a cidade que queremos". São Paulo: SMDU, 2012
} 
da opinião pública suficientes para atrair a atenção da mídia e da sociedade, e assim deflagrar a necessária pressão ao poder público para a priorização de políticas cicloviárias que contemplem o atendimento às suas reivindicações. Além de sua capacidade de articulação e facilidade de acesso à informações e aos polos de decisão, a principal arma destes movimentos é o seu íntimo vínculo a própria imagem rebelde e simpática da bicicleta agindo sob a égide da sustentabilidade representando, na composição do ideário do comportamento moderno, o resgate de um tipo de vida simples, honesto, saudável, preocupado com o coletivo, em contraposição aos padrões contemporâneos de comportamento urbano, que tendem ao egocentrismo, a monotonia, isolamento e ao consumismo.

Brinquedo, prática de esportes e principalmente modo de deslocamento cotidiano, o uso da bicicleta agrega dois estratos sociais bastante distintos. Um deles, majoritário, é constituído pela população pertencente às camadas de baixa renda (de 1 a 3 salários mínimos) e baixa escolaridade (até segundo grau incompleto). 0 outro grupo é formado por representantes da elite social situado entre as classes média e média alta, muitos exercendo algum tipo de atividade ligada ao terceiro setor ou ao setor de formação de opinião.

Nestas duas tribos distintas da sociedade, o motivo deflagrador do uso da bicicleta é sempre o mesmo: melhorar a qualidade de vida através da redução do tempo gasto com os deslocamentos diários. Mas o que diferencia a opção pela bicicleta nestes dois casos, é o tipo de transporte do qual estão migrando: enquanto que as camadas de baixa renda fogem da má qualidade dos serviços oferecidos pelos atuais sistemas transporte público, caríssimos, lentos e super lotados, a elite busca alternativa aos crônicos congestionamentos de trânsito enfrentados no interior de seus automóveis. 


\subsection{Contextualização do processo de produção das viagens de bicicleta em São Paulo no universo das viagens cotidianas}

0 processo de produção e reprodução brasileira e seus entraves se refletem sobre o espaço urbano na precariedade das infraestruturas de transporte e habitação e na informalidade das atividades econômicas e descontinuidades políticas.

No caso de São Paulo, decorrem destas condições gerais da reprodução social, as políticas públicas que conduzem à situação de carência crônica das infraestruturas urbanas, dentre as quais a de transporte público. Concomitantemente ocorre o direcionamento dos recursos públicos para os remendos da rede viária, na tentativa vã de se evitar seu sufocamento sob o volume crescente do transporte motorizado individual.

Cabe, no entanto apontar, inicialmente, como esta sociedade de elite trabalha suas formas políticas, e como se sustenta em relação a elas, conforme descrito por Deák e Schiffer (2007):

"A sociedade de elite desenvolve suas formas políticas particulares também. Assim, se a democracia é a forma política própria da sociedade burguesa, construída sobre a idéia de um bem-comum (Commonwwealth) e da concreta igualdade dos cidadãos perante a lei, na sociedade de elite ela se torna uma farsa porque o super-privilegiamento da elite contradiz qualquer noção de bemcomum, e a igualdade perante a lei simplesmente não existe" - ou em outra passagem do mesmo texto:

"A elite constantemente nega qualquer noção de interesse público, igualdade perante a lei, e vários outros princípios básicos da democracia. A elite faz (uma quantidade ilimitada de inconseqüentemente ambiciosas e ridiculamente detalhadas) leis somente para desrespeitá-las, e assim reafirma sua autoridade em ambos os movimentos: ela pode fazer a lei e ela pode infringi-la no momento seguinte; e essa dinâmica é socialmente aceita como normal."7

\footnotetext{
${ }^{7}$ Deák, Csaba; Schiffer, Suely “A Metrópole de uma sociedade de elite" - tradução Nuno Fonseca - 2007 ; Capítulo introdutório sobre São Paulo em SEGBERS, Klaus et alii (2007) The making of global city-regioins Johns Hopkins, Baltimore (no prelo) / site FAUUSP
} 
No que diz respeito ao tema deste trabalho, os entraves interpostos ao desenvolvimento econômico se manifestam nas formas em que o espaço urbano é ajustado às necessidades da produção e às demandas da população que nele vive. Nesse sentido, os sistemas de transporte urbano representam um importante papel, uma vez que não existe nenhuma atividade urbana que prescinda de deslocamentos das pessoas. Todos viajam, seja em busca de seu trabalho, de seu aprendizado, lazer ou cultura, seja para cuidar da saúde, da vida pessoal, afetiva, ou outro motivo qualquer.

Em São Paulo como já mencionado e de resto voz corrente, o transporte urbano coletivo, demandado por enormes contingentes de pessoas, é de grande precariedade e submete ao seu usuário redução dos seus índices de mobilidade pelo expressivo aumento do tempo gasto nos deslocamentos, de forma a comprometer a qualidade de vida urbana e dificultar o acesso às oportunidades. Esta situação tem levado mais pessoas a buscar saídas individuais para solucionar seus problemas de mobilidade. Em particular, entre a população de baixa renda, está se tornando mais presente, com o passar do tempo, o apelo às soluções não motorizadas, a saber, as viagens a pé e de bicicleta, conforme pode ser constatado pelos dados da OD 2007 expostos na Tabela 1.

\begin{tabular}{|l|c|c|c|c|c|c|}
\hline \multirow{2}{*}{ Modo Principal } & \multicolumn{7}{|c|}{ Salários Mínimos } \\
\cline { 2 - 7 } & Até 4 & De 5 a 8 & De 9 a 15 & $\mathbf{1 5}$ a 30 & $>30$ & Total \\
\hline Coletivo & 0,68 & 0,81 & 0,72 & 0,52 & 0,33 & 0,71 \\
\hline Individual & 0,24 & 0,59 & 1,14 & 1,78 & 2,30 & 0,58 \\
\hline Total Motorizada & 0,92 & 1,40 & 1,86 & 2,30 & 2,63 & 1,29 \\
\hline A pé + Bicicleta & 0,78 & 0,62 & 0,45 & 0,37 & 0,25 & 0,67 \\
\hline População & 9.668 .878 & 5.925 .220 & 2.670 .583 & 1.070 .632 & 199.307 & 19.534 .620 \\
\hline \% População & $49 \%$ & $30 \%$ & $14 \%$ & $5 \%$ & $1 \%$ & $100 \%$ \\
\hline
\end{tabular}

Tabela 1- Mobilidade: produção de viagens (per capita)

Segundo modo principal e faixa de renda (SM) / Mobilidade de viagens por faixa de renda $\left.{ }^{*}\right)$ Incl.Outros = bicicleta, caminhão etc.

Fonte: Pesquisa OD 2007 - apud Deák $2002^{8}$ elaborado com a OD 87 - atualizado para a OD 97 por Glaucia G. Pereira

\footnotetext{
${ }^{8}$ Deák, Csaba: Elementos de Uma Política de Transportes para São Paulo - Espaço e Debates (2002)
} 
Já o Gráfico 2 e Tabela 2 apontam, respectivamente, o tempo médio gasto nas viagens na Região Metropolitana de São Paulo por faixa de renda familiar e por modo de transporte das viagens motivo trabalho.
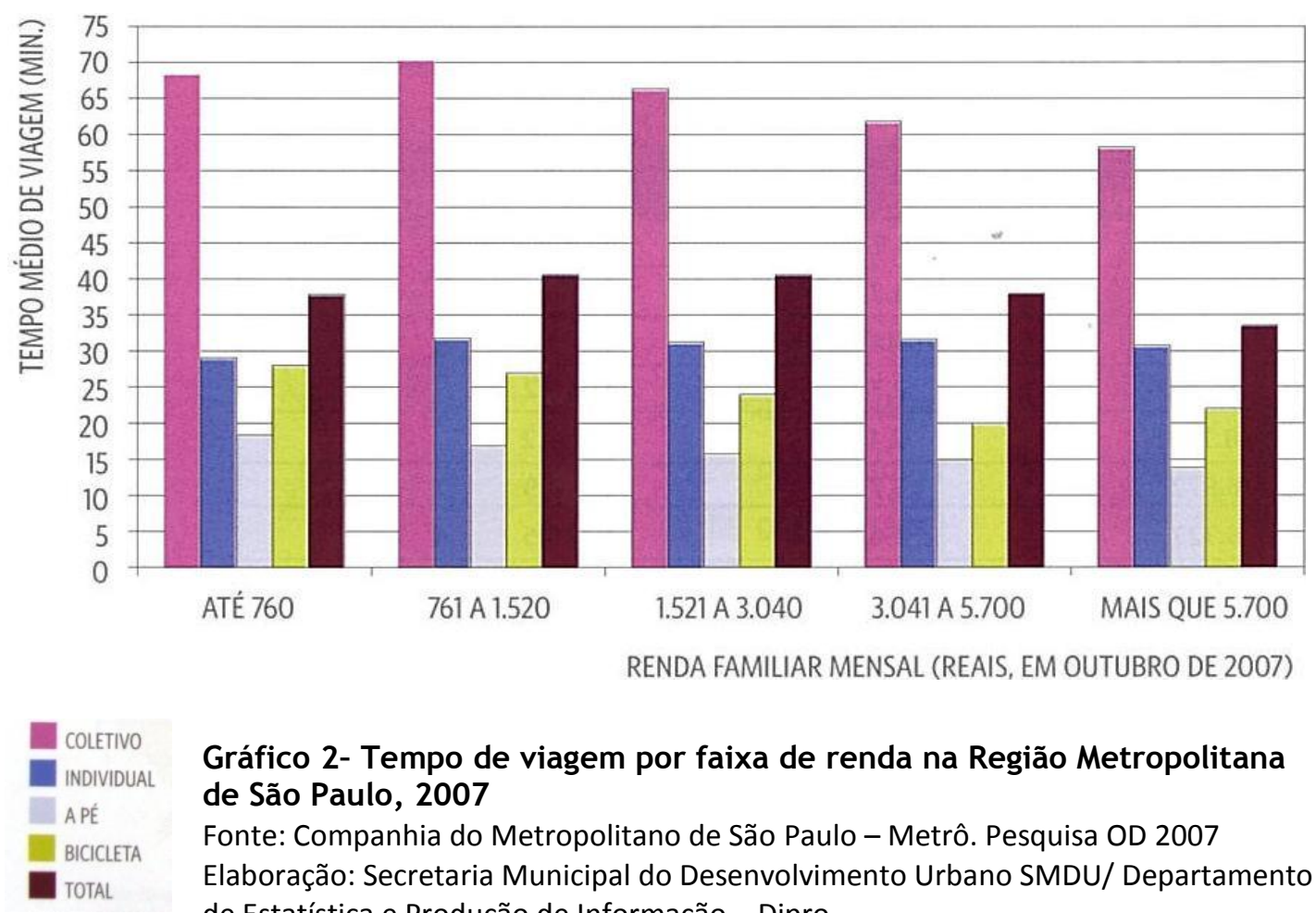

Gráfico 2- Tempo de viagem por faixa de renda na Região Metropolitana de São Paulo, 2007

Fonte: Companhia do Metropolitano de São Paulo - Metrô. Pesquisa OD 2007

Elaboração: Secretaria Municipal do Desenvolvimento Urbano SMDU/ Departamento de Estatística e Produção de Informação - Dipro

Nestes casos ficam constatados o maior tempo consumido pelas viagens por transporte coletivo e transporte não motorizado (a pé e por bicicleta) nas faixas de renda de até três salários mínimos ( até $R \$ 1520,00$ ), assim como os maiores consumos de tempo de viagem para os deslocamentos que envolvem os modos de transporte coletivo, sempre superiores à uma hora por viagem.

Por outro lado ao considerarmos a viagem de bicicleta em outras realidades urbanas veremos, como apontado por Vasconcellos, que a viagem de bicicleta aparece como o substituto da viagem a pé, e o seu uso enquanto modo de transporte apresenta à reboque, algumas características coincidentes com a realidade paulistana: "As pessoas que usam regularmente a bicicleta nos países em desenvolvimento pertencem aos estratos de renda mais baixa, uma vez que a bicicleta é o veículo mais barato na escala. $O$ uso da bicicleta tem limitações 
biológicas e implica em cuidados em relação à segurança, dificultando sua utilização pelos idosos e crianças muito pequenas"”. (Vasconcellos - 2000)

\begin{tabular}{|l|l|l|}
\hline MODO PRINCIPAL & $\begin{array}{l}\text { TEMPO MÉDIO DE } \\
\text { VIAGENS (MIN) }\end{array}$ & VIAGENS \\
\hline ÔNIBUS & 68 & 2.792 .474 \\
\hline TRANSPORTE FRETADO & 58 & 224.641 \\
\hline TRANSPORTE ESCOLAR & 26 & 3.571 \\
\hline AUTOMÓVEL & 37 & 2.824 .021 \\
\hline TÁXI & 41 & 17.794 \\
\hline METRÔ & 87 & 788.621 \\
\hline TREM & 93 & 327.097 \\
\hline MOTO & 29 & 295.752 \\
\hline BICICLETA & 27 & 109.206 \\
\hline A PÉ & 16 & 1.860 .736 \\
\hline OUTROS & 54 & 49.842 \\
\hline & & \\
\hline TOTAL & 49 & 9.293 .753 \\
\hline
\end{tabular}

Tabela 2- Tempo médio das viagens por modo - Região Metropolitana de São Paulo, $2007^{10}$ Fonte: Companhia do Metropolitano de São Paulo - Metrô. Pesquisa OD 2007

Elaboração: Secretaria Municipal do Desenvolvimento Urbano SMDU/ Departamento de Estatística e Produção de Informação - Dipro

Os percentuais da participação da bicicleta na composição das viagens em e São Paulo são bem reduzidos em relação a outras cidades da América do Sul, conforme apresentado no Gráfico 3.

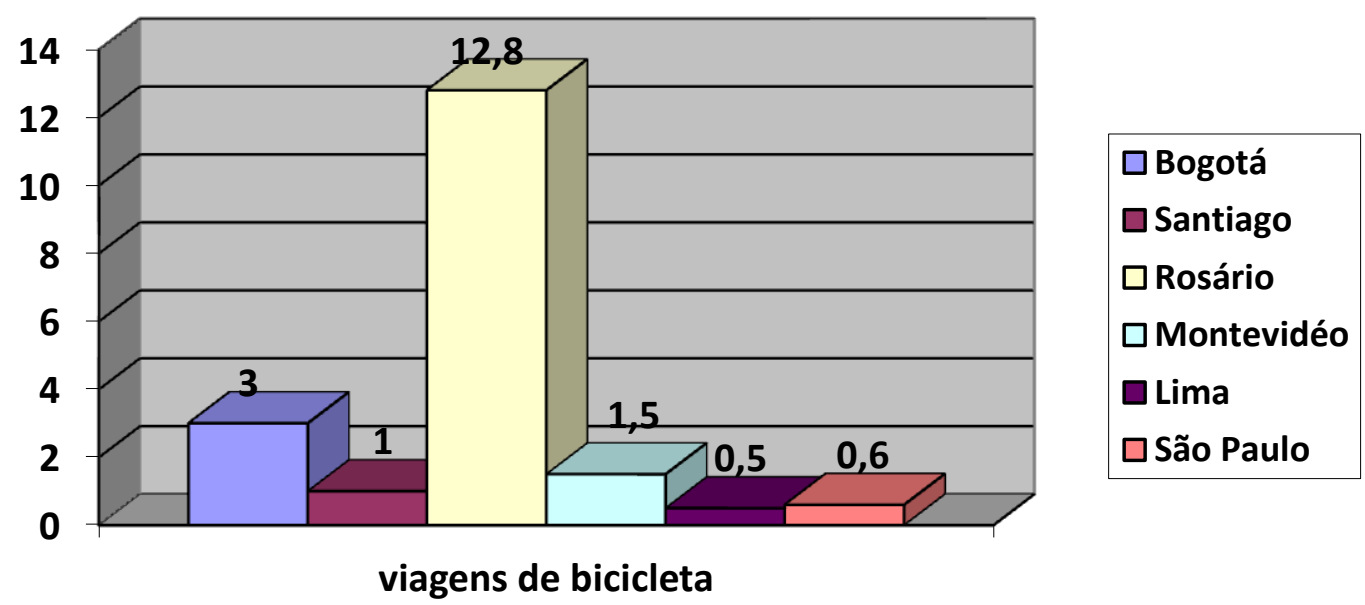

Gráfico 3- Viagens de bicicleta em relação ao total das viagens diárias, cidades de países da América do Sul(\%)

\footnotetext{
${ }^{9}$ Vasconcellos, Eduardo Alcântara "Transporte urbano nos países em desenvolvimento: reflexões e propostas" - Annablume / São Paulo. 2000

${ }^{10}$ Prefeitura do Município de São Paulo / Secretaria Municipal do Desenvolvimento Urbano "SP 2040: a cidade que queremos". São Paulo: SMDU, 2012
} 
Fontes: OD 2011 Alcadía Mayor de Bogotá, 2012, informe de indicadores - Encuesta de Movilidad de Bogotá 2011

OD 2001 Gobierno de Chile, Sectra, 2001, Encuesta origen-destino de viajes, resumen ejecutivo

OD 2008 Municipalidade de Rosario, 2008, Movilidad em El área metropolitana de Rosario

OD 2009 Intendencia de Montevideo, 2010, Hacia um sistema de movilidade accesible, democrático y eficiente, 2010-2020,

OD 2004 Conde, J. Romero, 2007, “La integración Del Servicio de Taxis Coletivos en el Sistema de Transporte Público urbano Del Área Metropolitana de Lima y Callao, Congresso Claptu, 2007

Mesmo inferior em relação à outras realidades urbanas como Rosário, Bogotá e Montevidéo, a recente intensificação do uso cotidiano da bicicleta em São Paulo expõe o processo de expansão descontrolada da cidade para periferias cada vez mais deficientes de infraestrutura urbana e de transportes, e destituídas de condições de vida e de trabalho, conforme afirmado por Deák e Schiffer (2007): "Com relação à organização espacial, que provê o suporte físico para a produção, tanto nacionalmente quanto nas aglomerações urbanas, temos uma infraestrutura cronicamente precária e irregularmente distribuída, e uma fragmentação mais do que uma homogeneização do espaço. Isso explica em muito a organização espacial em São Paulo"12

\footnotetext{
${ }^{11}$ Vasconcellos, Eduardo Alcântara - Dados de Observatorio Urbano de Movilidad Urbana de CAF / Banco de Desarollo de América Latina

${ }^{12}$ Deák, Csaba e Schiffer Sueli: “A Metrópole de Uma Sociedade de Elite" tradução de Nuno Fonseca - 2007, site FAUUSP
} 


\subsection{Objeto, objetivo e hipótese da pesquisa}

Considerando o pouco registro histórico do papel da bicicleta como modo de transporte, o atual fenômeno do crescimento do número de viagens ciclísticas no cotidiano paulistano carece de uma interpretação que leve em conta as dificuldades topográficas, climáticas e o ambiente urbano desfavorável. Este fenômeno terá que ser visto contra o pano de fundo do momento histórico, do quadro econômico e das circunstâncias sócio culturais em que ele se desenvolve.

Partindo deste princípio pode se definir como objetivo do trabalho, a busca e o reconhecimento dos motivos que resultaram neste fenômeno, elegendo como foco desta investigação a verdadeira representatividade da viagem cotidiana de bicicleta na mobilidade do universo pesquisado, no caso, o município de São Paulo.

Cabe destacar como cenário principal desta pesquisa, a situação de queda de qualidade de vida decorrente o aumento do tempo gasto nos deslocamentos diários, que consome atualmente cerca de uma hora e meia da vida útil das pessoas $^{13}$, decorrência direta das desastrosas políticas públicas de mobilidade praticadas sistematicamente pelos últimos governos. Ao atingir todas as camadas da população, acabam por levar à busca por soluções individualizadas para enfrentar as necessidades de locomoção. Assim, enquanto a população usuária do transporte público coletivo formada majoritariamente pelas camadas de menor faixa de renda apela aos modos não motorizados a pé e por bicicleta, os setores sociais economicamente privilegiados, que optaram inicialmente ao uso do transporte motorizado individual, ao se tornarem prisioneiros dos intermináveis congestionamentos de trânsito, também são atraídos pelos modais não motorizados, em especial pela bicicleta.

Esta última escolha também agrega como motivação, outro importante componente a ser destacado na definição do cenário da nossa pesquisa: a ideologia e consciência ambientalista e da contracultura iniciada nos Estados Unidos e Europa. Ela tem como principal mote a busca pela sustentabilidade e

\footnotetext{
${ }^{13}$ IBOPE Inteligência e Rede Nossa São Paulo - Tempo médio gasto no trânsito para realizar todos os deslocamentos diários/2011; São Paulo, 2012
} 
pela qualidade de vida através da simplicidade de ações e proximidade entre as pessoas no cotidiano urbano.

Sob este enfoque, a mobilidade ambientalmente correta seria a calcada nos modais de transporte não motorizados, No caso em questão, nos bem sucedidos hábitos e programas cicloviários originados em várias cidades européias e americanas. Assim, a recente intensificação do número de viagens de bicicleta no município de São Paulo, sob a ótica do poder público e da sociedade organizada, corre o risco de ser encarada como uma possibilidade para solucionar o crônico problema do deslocamento diário da população. Teria também como vantagem oferecer a chance de resgate de valiosos espaços públicos perdidos para o transporte motorizado individual.

Entretanto novamente convergindo o foco para a problemática da mobilidade paulistana já caracterizada neste documento, se faz necessário alertar para o risco de ser criado um paradoxo. Este paradoxo seria representado pela “queima de etapas" no planejamento e consolidação de políticas públicas de transporte, em especial do transporte cicloviário, se este for eleito como solução alternativa única a todos os tipos de viagens cotidianas, inclusive as que só são possíveis de serem atendidas através dos meios de transporte estruturais, de grande capacidade.

Esta constatação permite admitir, como hipótese deste trabalho, que a intensificação da utilização da bicicleta como veículo para o transporte cotidiano no município de São Paulo nos últimos anos, mais do que uma ação de raiz ambientalista, é uma fuga improvisada à precariedade dos serviços de transportes públicos disponíveis e a queda na qualidade da mobilidade urbana de forma geral.

A partir da definição desta hipótese, se torna mais do que necessário apontar a verdadeira função da viagem de bicicleta no deslocamento cotidiano paulistano de forma que o atual prestígio do transporte cicloviário não comprometa a esperada consolidação do que o município realmente necessita: um sistema efetivo, amplo e decente de mobilidade baseado nas redes de transporte público coletivo complementadas por sólidas redes de Transporte Não Motorizado a Pé e por Bicicleta, com investimentos maciços na infraestrutura que consolidem todas estas redes. 
Portanto criar estímulos à intensificação dos deslocamentos de bicicleta na cidade sem que haja investimentos sólidos na consolidação do transporte público coletivo como o modo principal, é constituir uma cortina de fumaça para ocultar a continuidade de políticas de preservação da precariedade das infraestruturas urbanas e dos sistemas de serviços públicos. Isto fará com que a cidade se aproxime aceleradamente de uma nova situação de impasse e conseqüentemente de novos níveis de queda na qualidade de vida urbana de sua população.

Assim a sobreposição destes cenários induz aos seguintes questionamentos:

a) sobre o real papel da viagem de bicicleta na matriz modal paulistana e, da validade de viabilizá-la como política de transporte sem antes suprir as deficiências da rede de transporte público coletivo atual;

b) sobre o significado do abrigo do transporte cicloviário no ideário ambientalista, considerando as características da realidade urbana paulistana, que bem define a bicicleta, seu espaço e seu usuário, tanto sob o enfoque físico como cultural. 


\section{CAPÍTULO 2}

\section{CARACTERIZAÇÃO DAS VIAGENS DE BICICLETA NA REGIÃO METROPOLITANA DE SÃO PAULO}




\section{A CARACTERIZAÇÃO DAS VIAGENS DE BICICLETA NA REGIÃO METROPOLITANA DE SÃO PAULO}

Neste capítulo será abordada a utilização da bicicleta na Região Metropolitana de São Paulo, um conglomerado formado por 39 municípios, onde se observa uma situação de conurbação entre o município São Paulo e os municípios desta região a ele limítrofes, onde se observa uma situação de indefinição de fronteiras e se consolida a formação de uma imensa mancha urbana. A intensa troca de atividades sociais e econômicas nela existentes gera numerosos deslocamentos diários por todos os modos de transporte, dentre eles os feitos por bicicleta, tendo como motivo principal a ida e volta ao trabalho, seguido pela educação.

Constata-se também que muito embora a média das viagens diárias de bicicleta nos municípios que compõem a Região Metropolitana pontue dois décimos a mais em relação ao município de São Paulo (0,8\% e 0,6\% respectivamente), elas estão abaixo dos padrões médios das cidades brasileiras de mesmo porte.

Cabe ainda acrescentar que as informações aqui expostas se apoiam principalmente nos dados da Pesquisa de Origem e Destino realizada pelo Metrô em 2007, reunidos em relatório técnico: “O Uso de Bicicletas na Região Metropolitana de São Paulo" e nos dados da ANTP sobre Mobilidade Urbana de 2007 e 2011.

\subsection{A representatividade das viagens de bicicleta na mobilidade da Região Metropolitana de São Paulo}

O aumento do uso da bicicleta nas viagens cotidianas do município de São Paulo e da sua Região Metropolitana é um fenômeno notado ao longo das últimas décadas, ao ponto de merecer registro exclusivo nas pesquisas de transporte realizadas pelo Metrô a cada dez anos a partir de 1977.

O relatório “O Uso de Bicicletas na Região Metropolitana de São Paulo" elaborado pelo Metrô, contem dados desta pesquisa e aponta em relação às 
viagens de bicicleta "tendência de crescimento, acompanhando a tendência mundial. Entre 1997 e 2007, na RMSP, o número de viagens exclusivamente de bicicleta quase dobrou, saltando de $162 \mathrm{mil}$ viagens/dia para $304 \mathrm{mil}$ viagens/dia...se considerarmos todas as viagens que envolvem algum trecho de bicicleta, chegaremos a $310 \mathrm{mil}$ deslocamentos (cerca de 6 mil viagens são realizadas por bicicletas, combinadas a outro modo: trem, metrô, ônibus ou automóvel)"14.

A Tabela 3 expõe série histórica das viagens da Região Metropolitana de São Paulo, a partir de 1977, quando passam a ser registradas as viagens diárias de bicicleta. É possível perceber o progressivo percentual de crescimento deste tipo de viagem no total das viagens realizadas, que adquire maior intensidade no decênio entre 1997 e 2007, quando se verifica acréscimo de três décimos porcentuais, o que corresponde a praticamente $200 \%$ a mais de viagens diárias. Além disso, se relacionarmos o número de viagens de bicicleta na região metropolitana pode ser constatado que elas triplicaram se compararmos 1987 e 2007 e dobraram entre 1997 e 2007.

\begin{tabular}{|l|c|c|c|c|c|c|c|c|c|c|}
\hline & \multicolumn{2}{|c|}{1967} & \multicolumn{2}{c|}{1977} & \multicolumn{2}{r|}{1987} & \multicolumn{2}{c|}{1997} & \multicolumn{2}{c|}{2007} \\
\hline Volumes & $(X 1.000)$ & $\%$ & $(X 1.000)$ & $\%$ & $(X 1.000)$ & $\%$ & $(X 1.000)$ & $\%$ & $(X 1.000)$ & $\%$ \\
\hline MODOS & & & & & & & & & & \\
\hline COLETIVO & 4.894 & 68,1 & 9.580 & 45,0 & 10.455 & 35,6 & 10.473 & 33,3 & 13.913 & 36,5 \\
\hline INDIVIDUAL & 2.293 & 31,9 & 5.683 & 26,7 & 8.187 & 27,8 & 9.985 & 31,8 & 11.254 & 29,5 \\
\hline BICICLETA & $*$ & $*$ & 71 & 0,3 & 108 & 0,4 & 162 & 0,5 & 304 & 0,8 \\
\hline A PÉ & $*$ & $*$ & 5.970 & 28,0 & 10.650 & 36,2 & 10.812 & 34,4 & 12.623 & 33,1 \\
\hline TOTAL & 7.187 & 100,0 & 21.304 & 100 & 29.400 & 100 & 31.432 & 100 & 38.094 & 100 \\
\hline
\end{tabular}

*Viagens não pesquisadas em 1967

Tabela 3 - Viagens por Modo de Tranporte - Região Metropolitana de São Paulo, 2007 Fonte: Companhia do Metropolitano de São Paulo - Metrô. Pesquisas OD/1967/1977/1987 e 2007 apud PMSP ${ }^{15}$

\footnotetext{
${ }^{14}$ Companhia do Metropolitano de SP - Metrô - "O Uso de Bicicletas na Região Metropolitana de São Paulo" site do Metrô

${ }^{15}$ Prefeitura do Município de São Paulo - "São Paulo 2040 - A cidade que queremos"
} 
A seguir no Mapa 1 é exibida a concentração do número de viagens de bicicleta por mil habitantes considerando a divisão por macrorregiões. Ele aponta maior densidade de viagens de bicicleta na região Leste na região metropolitana assim como à Noroeste e Oeste de regiões internas ao Município de São Paulo. O segundo nível na escala de densidade de viagens está a Oeste e Sudoeste da região metropolitana e forma uma espécie de cinturão incorporado pelos setores Sul, Centro-Sul e Nordeste do município paulistano. Finalmente o terceiro nível abrange duas manchas situadas nas regiões Noroeste da região metropolitana e do município de São Paulo e região Sudoeste do município de São Paulo.

Entretanto uma aferição mais apurada da intensidade de uso da bicicleta exposta neste mapa necessita de um refinamento em sua interpretação. 0 motivo é a aparência uniformizada das faixas de densidade nas áreas de macrorregiões definidas pela Pesquisa OD e não nas de ocupação urbana onde certamente ocorre a maioria das viagens ciclísticas.

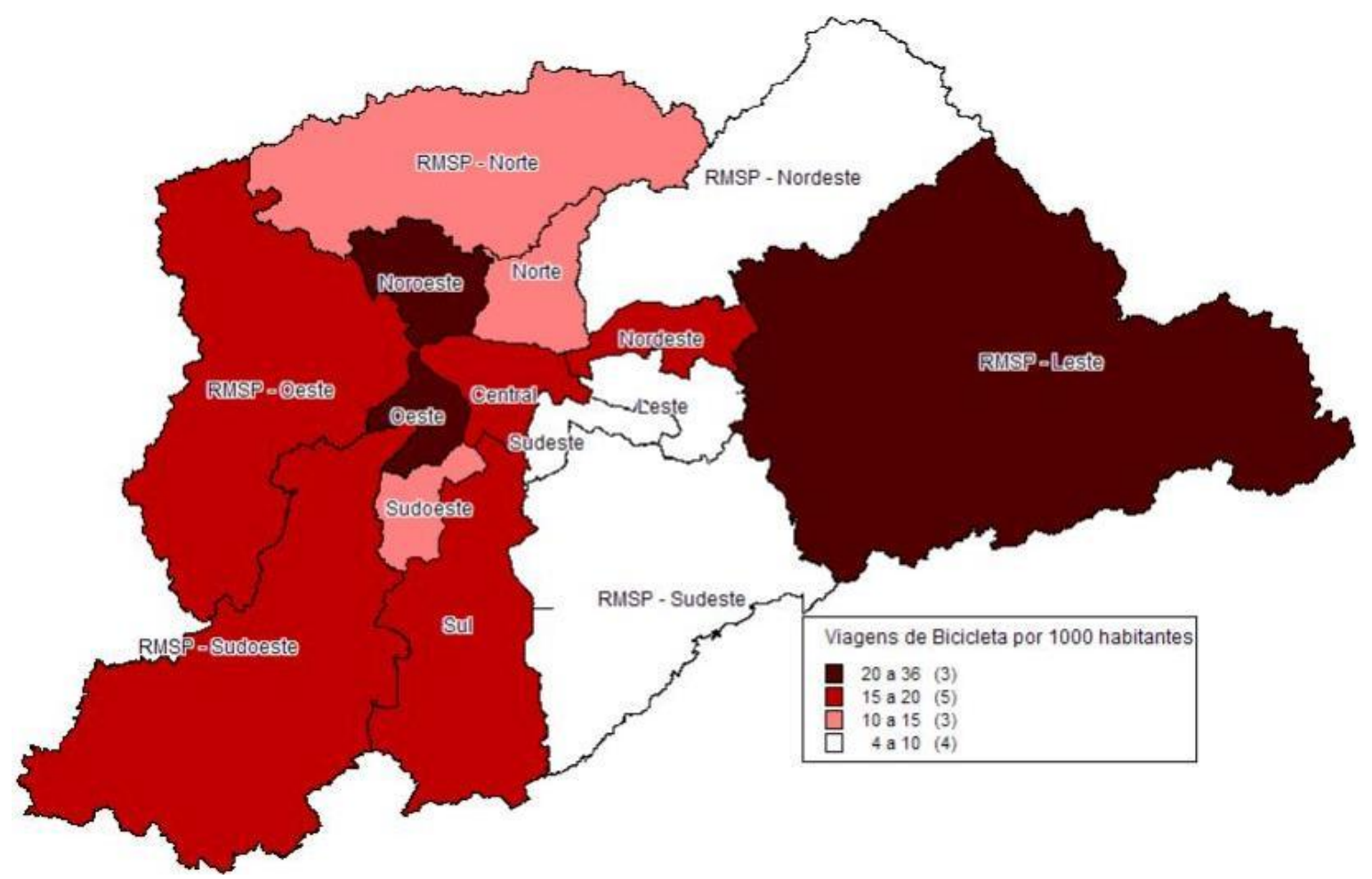

Mapa 1 - Densidade de viagens de bicicleta por 1000 habitantes nas macrorregiões da Região Metropolitana de São Paulo

Fonte: Pesquisa de Origem e Destino do Metrô - 2007 mapa elaborado por Glaucia G. Pereira 
Para tanto foi elaborado o Mapa 2 que sobrepõe a localização das faixas de densidade de viagens ciclísticas na região metropolitana expostas no Mapa 1 às manchas da ocupação urbana exibida por foto, de forma a permitir uma observação com maior propriedade dos locais onde ocorrem as maiores densidades de viagens ciclísticas, tanto nas áreas da região metropolitana como no município.

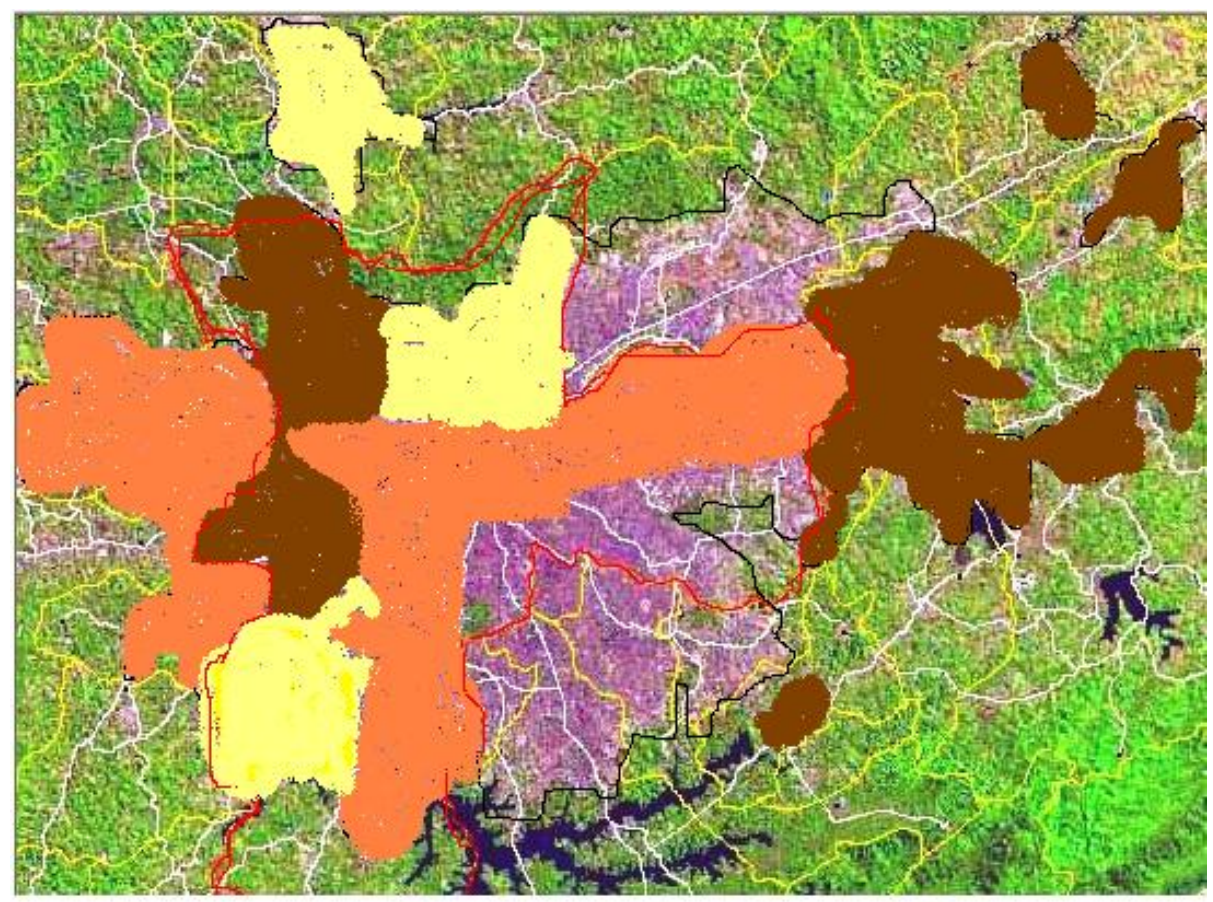

Viagens de bicicleta por 1000 habitantes na RMSP (considerando a mancha urbana)
$\square 20$ a 25
$\square 15$ a 20
10 a 15
0 a 19

Limite da mancha urbana da RMSP

Limite do Município de SP

Mapa 2 - Densidade de viagens de bicicleta por habitantes na mancha urbana da RMSP Fonte: Pesquisa OD Metrô 2007 / EMPLASA - Foto da mancha urbana da RMSP em 2009

Obs: Mapa elaborado pela autora a partir da sobreposição das informações do Mapa 1 com a foto da EMPLASA

\begin{tabular}{|l|r|r|r|r|}
\cline { 2 - 5 } \multicolumn{1}{c|}{} & \multicolumn{2}{c|}{ Região Metropolitana SP } & \multicolumn{2}{c|}{ Município - SP ${ }^{(1)}$} \\
\hline Modo Principal ${ }^{(2)}$ & Quantidade & Participação & Quantidade & Participação \\
\hline Bicicleta & 304.738 & $0,8 \%$ & 156.482 & $0,6 \%$ \\
\hline Trem & $\mathbf{8 1 5 . 3 2 2}$ & $2,1 \%$ & 626.964 & $2,5 \%$ \\
\hline Metrô & 2.223 .399 & $5,8 \%$ & 2.206 .448 & $\mathbf{8 , 6 \%}$ \\
\hline Ônibus/ Microônibus & 9.057 .977 & $23,7 \%$ & 6.503 .789 & $25,5 \%$ \\
\hline Automóvel & 10.413 .416 & $27,2 \%$ & 7.239 .774 & $28,4 \%$ \\
\hline A pé & 12.669 .737 & $33,1 \%$ & 7.389 .663 & $29,0 \%$ \\
\hline Outros (moto, táxi, escolar, etc) & 2.745 .218 & $7,2 \%$ & 1.402 .356 & $5,5 \%$ \\
\hline Total & 38.229 .808 & $100,0 \%$ & 25.525 .477 & $100,0 \%$ \\
\hline
\end{tabular}

Tabela 4 - Total de viagens diárias na RMSP e no Município de São Paulo

(1) Para viagens no município consideram-se com origem e/ou destino no município.

(2) Modo principal é o modo de maior hierarquia dentre os utilizados na mesma viagem (metrô, trem, ônibus, automóvel, bicicleta, a pé)

Fonte: Pesquisa OD Metrô/2007 elaborada pela CET / GPL / DPJ - 2009 
A representatividade da viagem de bicicleta na matriz modal da região metropolitana assim como no município de São Paulo podem ser constatadas pelos dados contidos na Tabela 4 e Gráfico 4.

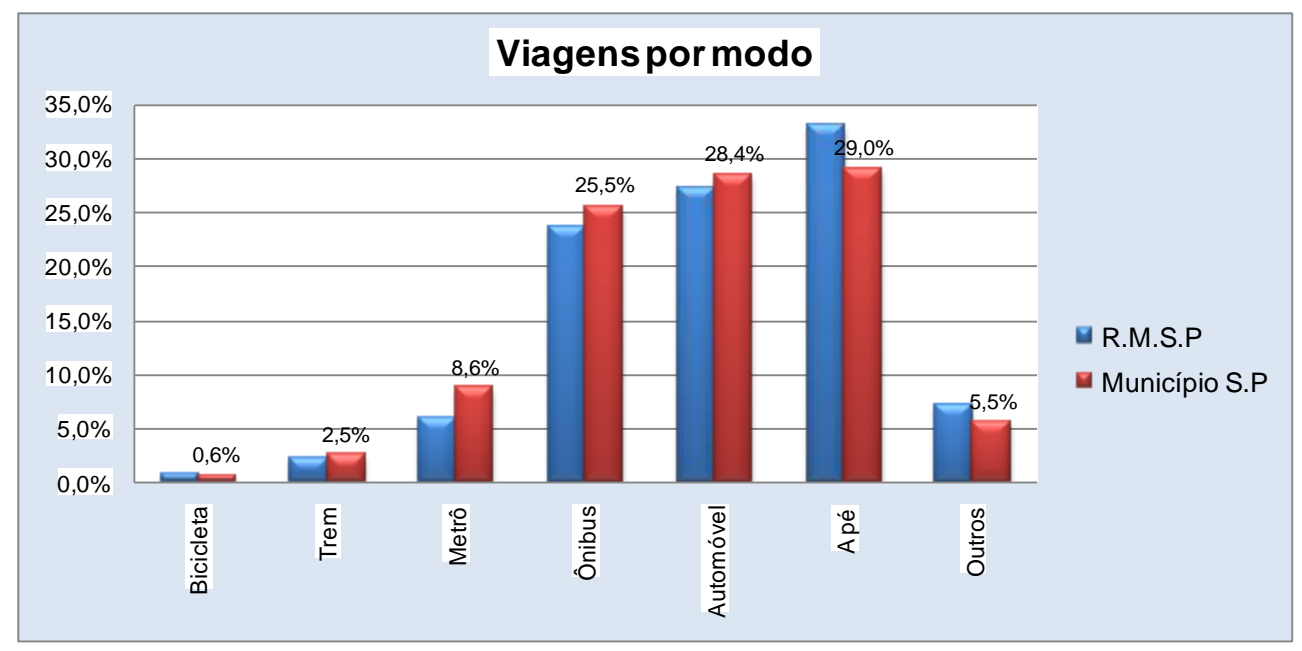

Gráfico 4 - Distribuição das viagens diárias por modo - RMSP e MSP

Fonte: Pesquisa OD Metrô/2007 elaborada pela CET / GPL / DPJ - 2009

Ambos apontam índices inferiores à $1 \%$ do total de viagens diárias, com índices da região metropolitana levemente superiores aos do município de São Paulo: $0,8 \%$ e $0,6 \%$ respectivamente.

Conforme levantamento do Sistema de Informações da Mobilidade Urbana da ANTP em $2007^{16}$ e 2011 respectivamente, estes índices ficam abaixo da média das viagens de bicicleta de cidades brasileiras, conforme exposto nos Gráficos 5 e 6 .

Para seguir os padrões médios de viagens de bicicleta de cidades brasileiras aferidos pela ANTP os municípios da região metropolitana com população entre 500 mil a 1 milhão de habitantes, como Santo André, São Bernardo e Osasco ${ }^{17}$, deveriam ter $2 \%$ dos deslocamentos diários feitos por bicicletas. Já cidades menores entre 60 e 100 mil habitantes, como Arujá, Vargem Grande Paulista e Rio Grande da Serra estes porcentuais deveriam subir para até $10 \%$. Portanto o uso da bicicleta na Região Metropolitana de São Paulo tem índices inferiores aos da média da maioria das cidades brasileiras.

\footnotetext{
${ }^{16}$ ANTP; Associação Nacional dos Transportes Públicos : "Sistema de Informações da Mobilidade Urbana de 2007" - site da ANTP 2013

${ }^{17}$ Dados de população retirados da Pesquisa de Origem e Destino do Metrô de 2007
} 


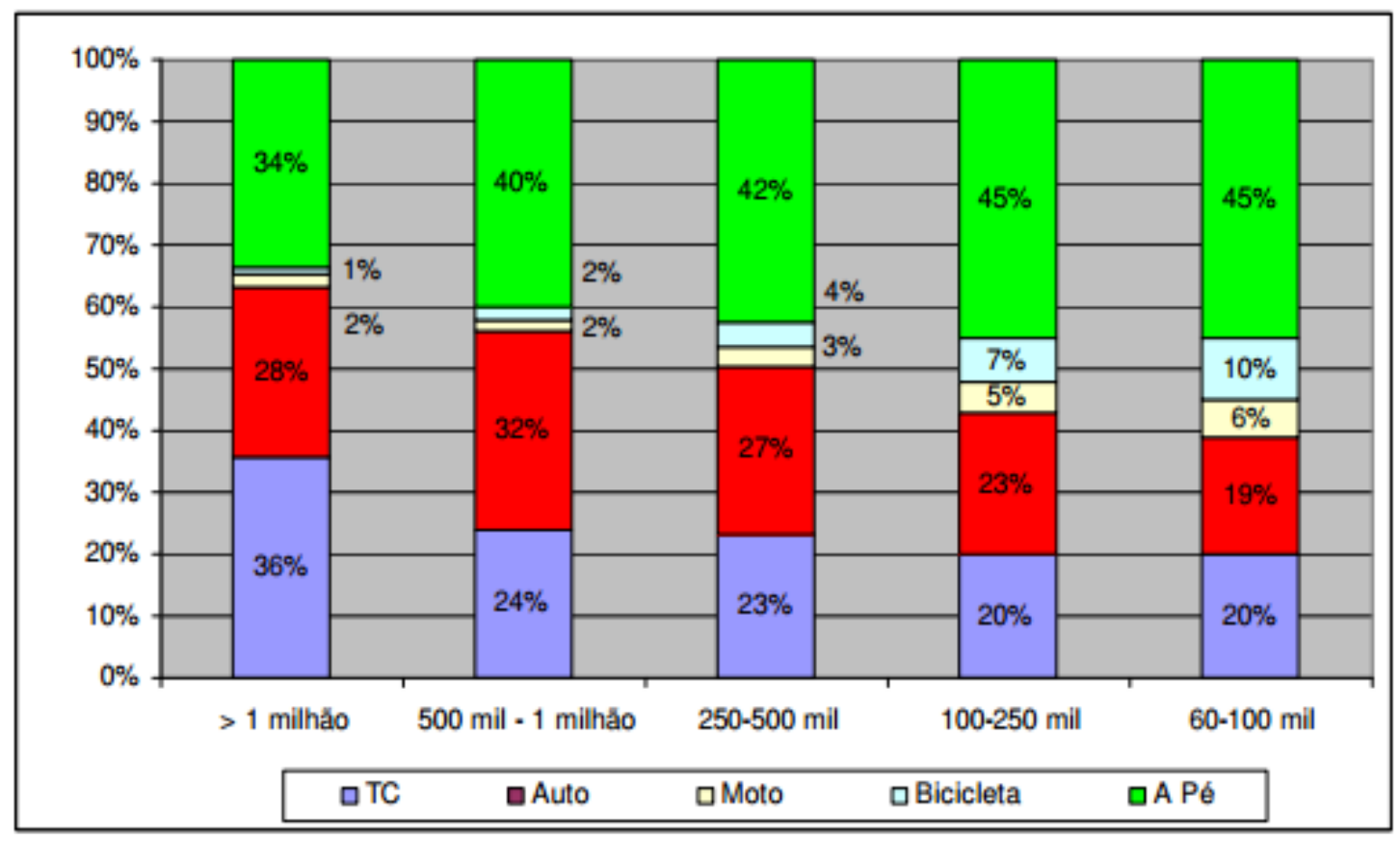

Gráfico 5- Divisão modal por porte de município - 2007

Fonte: site ANTP - Relatório Sistema de Informações da Mobilidade Urbana de 2007

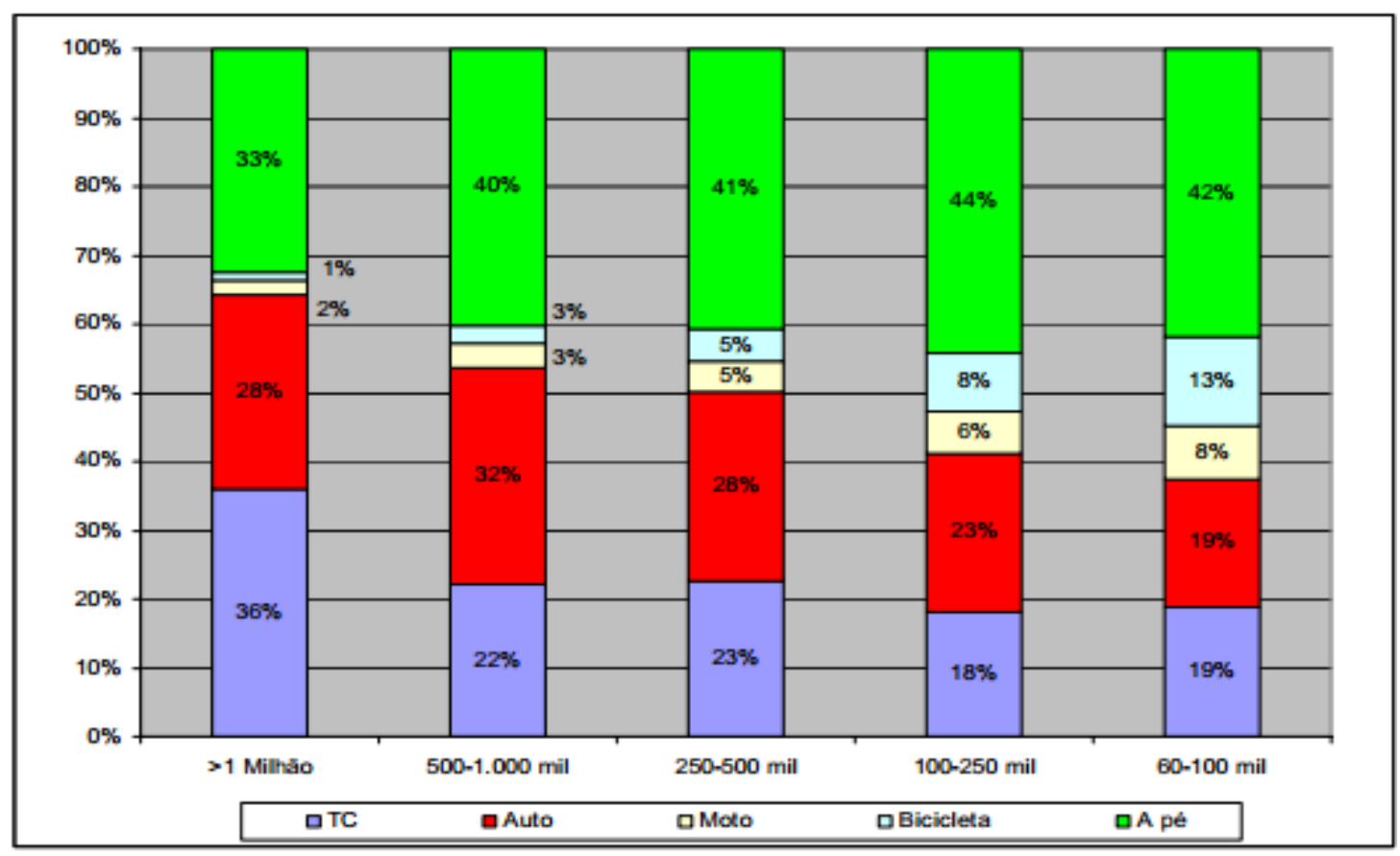

Gráfico 6 - Divisão modal por porte de município - 2011

Fonte: site ANTP - Relatório Sistema de Informações da Mobilidade Urbana de 2011 


\subsection{A distribuição das viagens de bicicleta entre os municípios que compõem A RMSP}

Do total de viagens diárias da Região Metropolitana, 0,8\% são realizadas por bicicleta, sendo que 51,2\% destas viagens está concentrada no município de São Paulo, onde perfaz $0,6 \%$ de todas as viagens diárias do município.

\begin{tabular}{|c|c|c|c|c|c|}
\hline $\begin{array}{l}\text { Município de } \\
\text { Origem }\end{array}$ & Trabalho & $\begin{array}{l}\text { Escola/ } \\
\text { Educação }\end{array}$ & $\begin{array}{l}\text { Recreação/ } \\
\text { Lazer }\end{array}$ & $\underset{*}{\text { Outros }}$ & Total \\
\hline São Paulo & 97.272 & 21.638 & 10.565 & 17.632 & 156.482 \\
\hline Guarulhos & 14.478 & 1.677 & 0 & 6.330 & 22.485 \\
\hline Mogi das Cruzes & 9.740 & 8.493 & 267 & 1.235 & 19.735 \\
\hline S. Bern. Campo & 15.014 & 0 & 0 & 1.098 & 16.112 \\
\hline Santo André & 10.081 & 466 & 0 & 467 & 11.014 \\
\hline Suzano & 7.358 & 2.362 & 0 & 170 & 9.891 \\
\hline Diadema & 4.779 & 0 & 0 & 3.245 & 8.025 \\
\hline Itaquaquecetuba & 7.836 & 0 & 0 & & 7.836 \\
\hline Osasco & 4.566 & 0 & 196 & 2.693 & 7.455 \\
\hline Barueri & 5.032 & 237 & 823 & 0 & 6.091 \\
\hline Arujá & 4.403 & 0 & 0 & 0 & 4.403 \\
\hline Poá & 3.656 & 403 & 0 & 98 & 4.157 \\
\hline Vargem G. Pta. & 3.549 & 0 & 447 & 0 & 3.996 \\
\hline Cotia & 3.715 & 223 & 0 & 0 & 3.938 \\
\hline Ferraz de Vasc. & 3.719 & 0 & 0 & 0 & 3.719 \\
\hline Itapevi & 0 & 0 & 0 & 3.336 & 3.336 \\
\hline Mauá & 1.364 & 0 & 0 & 1.385 & 2.750 \\
\hline S. Caetano Sul & 1.319 & 1.069 & 0 & 136 & 2.525 \\
\hline Guararema & 1.794 & 0 & 0 & 434 & 2.228 \\
\hline Santana Parna. & 2.207 & 0 & 0 & 0 & 2.207 \\
\hline Cajamar & 1.286 & 751 & 0 & 0 & 2.037 \\
\hline Sta. Izabel & 1.641 & 0 & 0 & 323 & 1.964 \\
\hline Embú & 1.578 & 0 & 0 & 182 & 1.761 \\
\hline Embú Guaçú & 962 & 0 & 0 & 521 & 1.483 \\
\hline Itapec. Serra & 962 & 0 & 0 & 0 & 962 \\
\hline Carapicuíba & 957 & 0 & 0 & 0 & 957 \\
\hline Mairiporã & 858 & 0 & 0 & 0 & 858 \\
\hline R. Gde. Serra & 510 & 0 & 0 & 319 & 829 \\
\hline Biritiba Mirim & 624 & 0 & 0 & 179 & 804 \\
\hline S. Lour. Serra & 776 & 0 & 0 & 0 & 776 \\
\hline Ribeirão Pires & 532 & 102 & 0 & 0 & 634 \\
\hline Salesópolis & 578 & 0 & 0 & 0 & 578 \\
\hline Taboão Serra & 300 & 230 & 0 & 0 & 530 \\
\hline Juquitiba & 349 & 0 & 0 & 0 & 349 \\
\hline Jandira & 198 & 0 & 0 & 0 & 198 \\
\hline Pirapora B. J. & 100 & 0 & 0 & 0 & 100 \\
\hline Total RMSP & 214.095 & 37.651 & 12.298 & 39.786 & 304.738 \\
\hline
\end{tabular}

Tabela 5 - Motivo das viagens de bicicleta nos municípios da RMSP

(*) Outros: Compras, Saúde, Procurar emprego e Assuntos Pessoais Fonte: Relatório “O Uso de Bicicletas na Região Metropolitana de São Paulo” Metrô-2007 
A Tabela 5 apresenta por ordem decrescente a relação dos municípios da RMSP com os motivos das viagens de bicicleta de cada um deles.

De forma geral estas viagens tiveram como motivo principal Trabalho (71\%), seguido por Escola/Educação (12\%), e Visitas/Lazer (4\%), significando, portanto que os dois dos motivos que mais demandam viagens pendulares diárias são de caráter utilitário e os motivos restantes se caracterizam por viagens avulsas, de motivos diversos.

O motivo "Outros" agrega Saúde, Compras, Procura por Emprego e Assuntos Pessoais, apontando a bicicleta como opção de veículo de transporte individual para uma parcela da população.

A Tabela 5 também expõe peculiaridades de diversos municípios que compõem a RMSP pela distribuição dos motivos de viagem, o que permite perceber a sua natureza enquanto hábitos e funções. Na grande maioria deles predomina o uso de bicicleta para ida ao trabalho: São Paulo, Guarulhos, São Bernardo, Santo André, Arujá, Itapecerica, Mairiporã.

Em outros como Mogi das Cruzes, São Caetano do Sul e Taboão da Serra, o número de viagens de bicicleta motivo Escola/Educação é muito próximo ao número de viagens motivo Trabalho e pode apontar intensificação de uso do solo para esta finalidade cuja extensão que se encaixa ao uso da bicicleta.

Já em Diadema, Itapevi, Mauá, o motivo Outros ou é dominante no total de viagens ou muito próximo ao principal motivo de viagem da maioria dos municípios que é Trabalho, registrando uso mais generalizado da bicicleta.

Por último o motivo Recreação / Lazer tem sua representatividade puxada por São Paulo onde sua presença é a mais significativa, deixando claro que a bicicleta ainda pode ser utilizada por muitos como um recurso de lazer.

A natureza das atividades predominantes em cada um destes municípios certamente é fator decisivo, mas praticamente em todos eles fica o registro da utilização da bicicleta como transporte em deslocamentos cotidianos. 


\subsection{Dados complementares das viagens de bicicleta da Região Metropolitana}

Outros indicativos são típicos das viagens utilitárias de forma geral, como a faixa horária de início das viagens coincidindo com a faixa de horário dos demais modais, ou seja, período da manhã entre 6 e 9 horas e à tarde entre 18 e 19 horas, com um pequeno entre pico às 13 horas, conforme demonstrado pelo Gráfico 7. Este entre pico pode confirmar a escolha da bicicleta pela pequena distância entre a casa e o trabalho ou escola, com retorno à residência para o almoço ou início / término de período escolar.

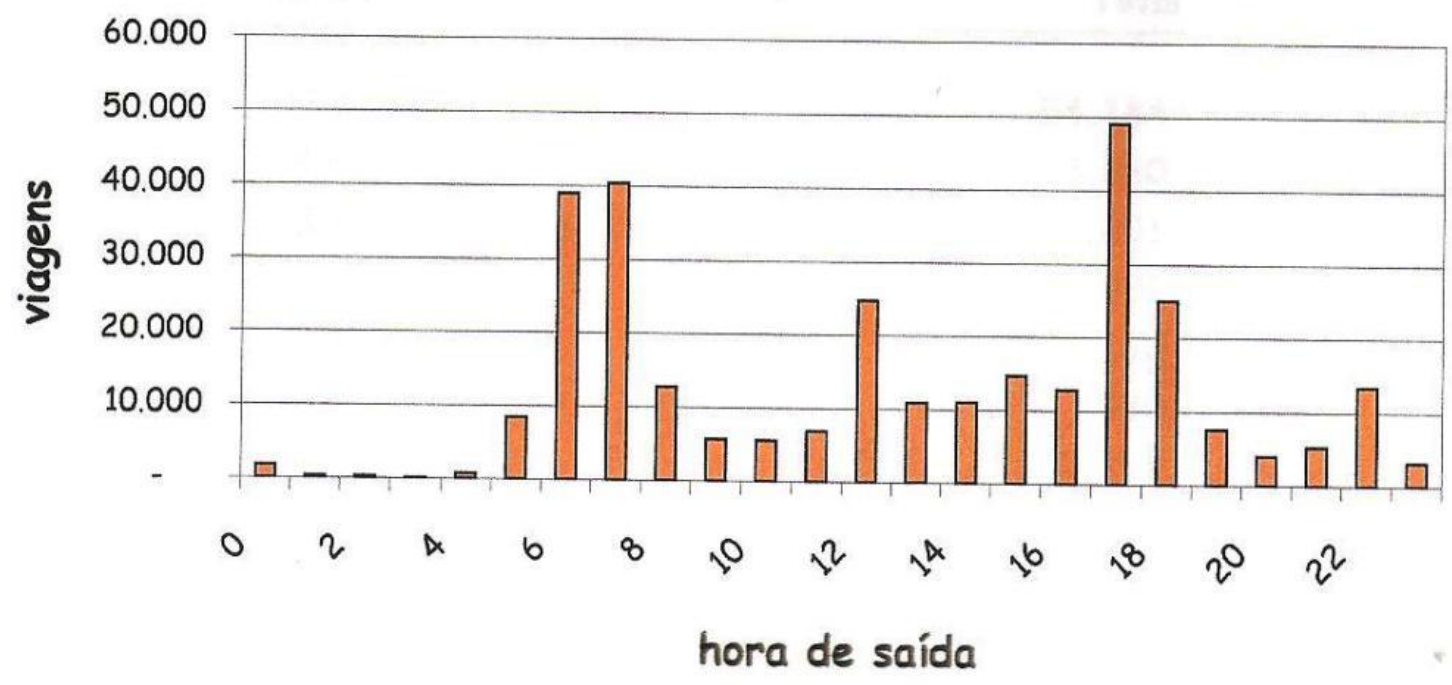

Gráfico 7 - Horários de saída das viagens de bicicleta na RMSP

Fonte: Relatório “O Uso de Bicicletas na Região Metropolitana de São Paulo” Metrô-2007

Mais uma informação relevante relaciona-se à escolha do veículo bicicleta para uso diário, tendo como motivo mais alegado a pequena distância, com quase $60 \%$ das indicações, seguido pelo alto custo do transporte $22 \%$, e por outros problemas relacionados à má qualidade dos serviços do transporte público, como "ponto distante" ( $4 \%$ ), "condução demora a passar" (8\%), "viagem demorada" (2\%), "condução lotada"( $2 \%$ ). Se somados totalizam $16 \%$. As duas outras justificativas alegadas são "atividade física" seguida por "outros motivos". A Tabela 6 e o Gráfico 8 apresentam a classificação das justificativas. 


\begin{tabular}{lrr}
\hline & \multicolumn{2}{c}{ Viagens de Bicicleta } \\
\cline { 2 - 3 } Razão da Escolha & $(\times 1.000)$ & $\%$ \\
\hline & 172 & 56,6 \\
Pequena distância & 67 & 22,0 \\
Condução cara & 4 & 1,3 \\
Ponto / estação distante & 8 & 2,6 \\
Condução demora para passar & 2 & 0,7 \\
Viagem demorada & 2 & 0,7 \\
Condução lotada & 20 & 6,6 \\
Atividade Fisica & 29 & 9,5 \\
Outros motivos & & \\
\hline TOTAL & 304 & 100,0 \\
\hline
\end{tabular}

Tabela 6 - Justificativas da escolha da bicicleta na realização das viagens da RMSP Fonte: Relatório “O Uso de Bicicletas na Região Metropolitana de São Paulo” Metrô-2007

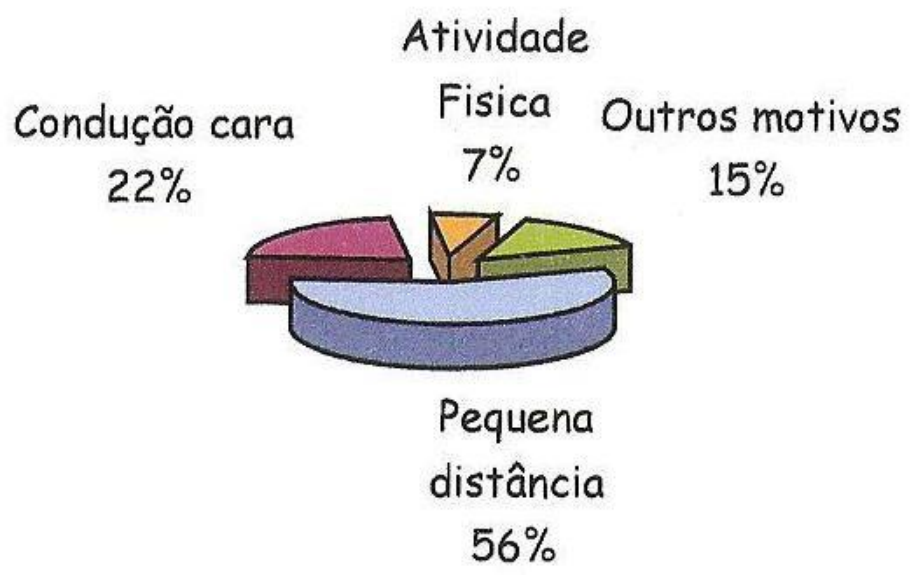

Gráfico 8 - Justificativas da escolha da bicicleta na realização das viagens da RMSP

Fonte: Relatório “O Uso de Bicicletas na Região Metropolitana de São Paulo” Metrô-2007

Outro aspecto interessante diz respeito à faixa etária e o gênero dos usuários diários da bicicleta. O vigor físico e a ousadia exigidos para pedalar no trânsito, ficam evidenciados na Tabela 7, com a grande maioria dos ciclistas composta de homens jovens e adultos de 15 a 49 anos, perfazendo um total dez vezes maior do que o uso por mulheres.

Quanto à utilização feminina da bicicleta, chama atenção a alta do uso de bicicleta por mulheres nas as faixas etárias dos 30 aos 39 anos que supera em $200 \%$ à faixa etária que a precede, compreendida entre os 23 a 29 anos. Este 
fato poder ser explicado pela intensificação de atividades profissionais por mulheres nesta faixa etária.

Sexo

\begin{tabular}{rrrrr}
\hline Faixa Etária (anos) & Masculino & Feminino & Total \\
\hline 4 a 6 & 6.341 & 1.816 & 8.157 \\
7 a 10 & 2.304 & 896 & 3.200 \\
11 a 14 & 6.548 & 2.410 & 8.958 \\
15 a 17 & 22.352 & 1.771 & 24.123 \\
18 a 22 & 35.250 & 2.618 & 37.869 \\
23 a 29 & 58.372 & 3.270 & 61.642 \\
30 a 39 & 77.399 & 11.678 & 89.077 \\
40 a 49 & 45.125 & 1.816 & 46.940 \\
50 a 59 & 14.182 & 1.549 & 15.731 \\
60 ou mais & 8.131 & - & 8.131 \\
\hline Total & 276.003 (91\%) & $27.825(9 \%)$ & 303.828 \\
\hline
\end{tabular}

Tabela 7 - Distribuição dos usuários cotidianos de bicicleta por faixa etária e sexo Fonte: Relatório “O Uso de Bicicletas na Região Metropolitana de São Paulo” Metrô-2007

O uso da bicicleta como veículo cotidiano exige, além de infraestrutura viária de circulação, locais para estacionamento e guarda. Assim a previsão de paraciclos, "Paraciclo: Dispositivo que permite apoiar e fixar a bicicleta estacionada. Pode ser implantado na via ou logradouro público (desde que não atrapalhe a circulação do ciclista)" e bicicletários "Bicicletário: Local fechado dotado de zeladoria e destinado ao estacionamento de bicicletas"18 consolida a viabilidade da bicicleta como transporte cotidiano.

Conforme exposto pelo Gráfico 9, as pesquisas apontam que a guarda da bicicleta na RMSP ocorre, na grande maioria, em locais privados (61\%) e bicicletários gratuitos (15\%) e pagos (1\%). A existência deles é condição necessária para garantir a integridade do veículo por um longo período de permanência característico da integração modal motivo trabalho. 0 estudo aponta também a insuficiência do número de vagas em bicicletários gratuitos integrados à estações e terminais de transporte público, apesar da recente implantação de bicicletários pela CPTM e Metrô: “... existem algumas iniciativas que favorecem o uso de bicicletas, principalmente nas estações de

\footnotetext{
${ }^{18}$ Site da Companhia de Engenharia de Tráfego do Município de São Paulo - Consultas / Bicicleta / Definições
} 
trem. São quase 4 mil vagas para bicicletas em diversas estações de trem, contra apenas 100 do Metrô. .... Nas estações de trem, mediante cadastro, é possivel utilizar bicicletários gratuitos. A CPTM procura revitalizar, construir e fazer a integração. Hoje a Companhia oferece 3.850 vagas em 12 bicicletários. Destas, 250 estão em Itaim Paulista, outras 250 em Jardim Helena/Vila Mara, 65 em Caieiras e 250 na USP Leste. Há mais 200 em Comendador Ermelino, 90 em Pinheiros, 255 em Jurubatuba, além de 255 em Autódromo, 250 em PrimaveraInterlagos. Grajaú tem 180, Itapevi, 70; e Mauá, 1.700”19.

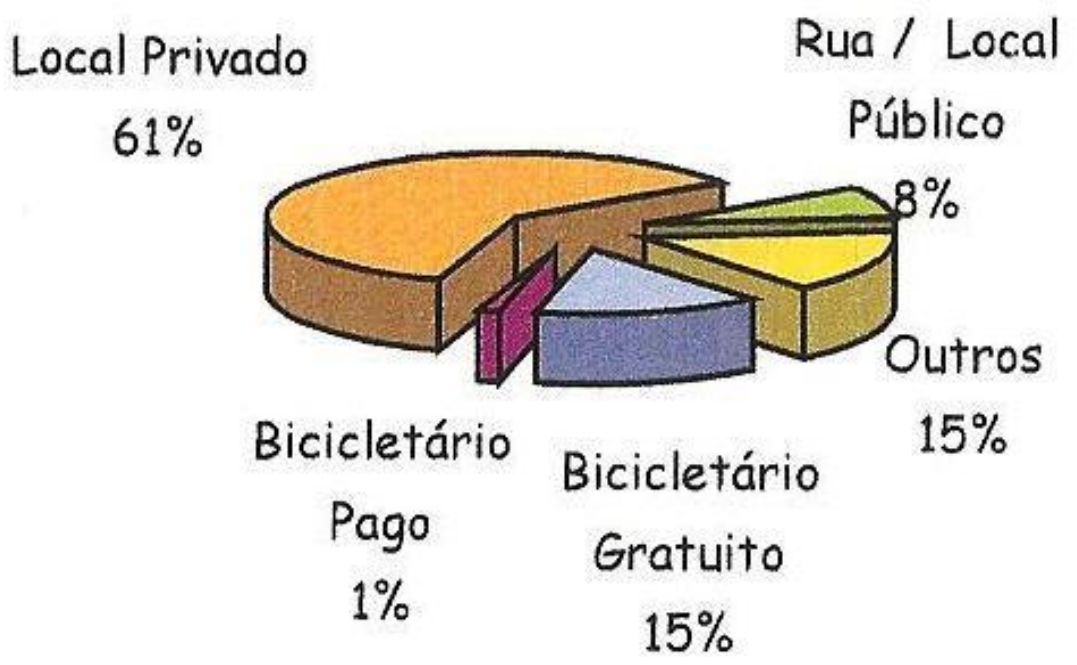

Gráfico9:Opções de locais para a guarda de bicicletas (bicicletários Fonte: Relatório “O Uso de Bicicletas na Região Metropolitana de São Paulo” Metrô-2007

Outra parte desta demanda é representada pelas viagens locais de prestação de serviços, caracterizadas por serem de pouca extensão e o estacionamento de curta duração, que podem estar inseridas no estudo pela utilização de ruas ou de locais públicos $(8 \%)$.

\footnotetext{
${ }^{19}$ Jornal “O Estado de São Paulo", edição de 26/07/2008 - “CPTM amplia bicicletários em estações de trem de SP"
} 
CAPÍTULO 3

\section{A BICICLETA NO MUNICÍPIO DE SÃO PAULO: O VEÍCULO E SEU CONTEXTO URBANO}




\section{A BICICLETA NO MUNICÍPIO DE SÃO PAULO: O VEÍCULO E SEU CONTEXTO URBANO}

Este capítulo inicia propriamente a exposição e análise de informações que subsidiarão o desenvolvimento desta tese e suas conclusões. São tabelas e dados baseados na última pesquisa de Origem e Destino realizada pelo Metrô em 2007, muitos dos quais detalhados para estudos internos por técnicos da CET / SP, além de do relatório "Dados e Estatísticas de Trânsito da CET" de 2012.

As características típicas das viagens de bicicleta, do seu usuário e de suas condições de vulnerabilidade refletem a difícil vivência do dia a dia encontrada por quem busca na locomoção cicloviária uma forma de se deslocar no município. Elas apontam claramente a localização das regiões com os maiores problemas de mobilidade e definem o tipo de usuário que tem maior resistência em aceitar os baixos padrões oferecidos pelos atuais sistemas de transporte públicos e optam pelo uso da bicicleta. Eles acreditam que mesmo sem contar com uma condição mínima de qualidade exigida pelas características do veículo, encontram alguma vantagem na sua utilização.

Neste capítulo também fica registrada a presença cada vez mais comum da bicicleta de entregas e de carga como alternativa de agilização de prestação de serviços.

Deve ser esclarecido que o relato das informações aqui registradas pretende explicar os atuais padrões da mobilidade cicloviária e as possibilidades de mudança que possam ocorrer com a intensificação da inserção da bicicleta na realização dos deslocamentos cotidianos do município. Pautou grande parte deste relato o acúmulo de material possibilitado pela vivência profissional de muitos anos dedicados ao assunto na administração municipal. ${ }^{20}$.

\footnotetext{
${ }^{20}$ Também não posso deixar de registrar que acredito profundamente no Transporte Não Motorizado - a Pé e por Bicicleta como opções reais e definitivas de transporte para o Município de São Paulo, desde que recebam adequado tratamento como ações de política urbana e dividam com todos os modos motorizados seus verdadeiros e definitivos espaços na cidade.
} 


\subsection{A Bicicleta: o veículo e seu processo de apropriação do espaço público paulistano.}

A infraestrutura viária paulistana caracteriza-se por ser priorizada para o automóvel e assim não facilita a vida de quem se desloca sem motor na cidade. Assim pedestres e ciclistas, sistematicamente preteridos no cotidiano da mobilidade paulistana, reagem a este ambiente urbano exercendo diariamente sua sobrevivência através da criação e prática de regras próprias de circulação, na grande maioria das vezes não coincidentes com o que é definido e imposto pela legislação de trânsito vigente.

Complementando o cenário, destaca-se o desordenado crescimento da cidade sem maiores preocupações com o planejamento da mobilidade e o controle do uso dos espaços públicos a ela destinados, relegando sempre ao segundo plano as ações demandadas dos modos de transporte que não o automóvel. A estrutura deste modelo de deslocamento, altamente suportado no transporte motorizado individual, sacrifica a qualidade da vida urbana da população ao torná-la prisioneira de infindáveis congestionamentos de trânsito e vítima da má qualidade dos serviços de transportes públicos coletivos, insuficientes e caros. Também neste caso uma parte dos paulistanos usuários destes sistemas busca nos modos de transporte não motorizados uma saída para suas dificuldades, atitude esta primeiramente constatada na intensificação das viagens a pé e mais recentemente nas viagens de bicicleta.

Este processo ocorre concomitantemente às ideologias ambientalistas deflagradas no primeiro mundo, que buscam alternativas sustentáveis para as atividades cotidianas, e por este caminho, elegem a bicicleta como modo de transporte. Seus adeptos pertencem à elite que sempre apoiou seus deslocamentos diários no transporte motorizado individual. Articulados e bem informados, ao se depararem com o ambiente hostil que a cidade oferece para quem pedala, pressionam o poder público para preparar rapidamente uma cidade apropriada para suas bikes. 
Desta forma o processo de apropriação da cidade por bicicleta é realizado por cidadãos pertencentes a dois segmentos distintos da sociedade: um deles, majoritário, é constituído pela população diretamente afetada pela má qualidade do transporte público, que vê na bicicleta uma saída para melhorar sua vida economizando tempo de viagem e custo da tarifa; o outro sem representatividade numérica suficiente para ser detectado pelas atuais pesquisas de transporte, mas com articulação e poder suficientes para exercer influência na modelagem das políticas públicas, pertence às camadas de elite.

Esta dicotomia se reflete na forma ambígua com que o veículo bicicleta é contemplado nas políticas públicas, como será constatado ao longo não só deste capítulo como também do trabalho. 


\subsection{As viagens por bicicleta no Município de São Paulo}

As características das viagens por bicicleta em São Paulo seguem as mesmas tendência verificadas na Região Metropolitana, em decorrência da polarização representada pela centralização das atividades econômicas no município paulistano e da situação de conurbação verificada entre os municípios que the fazem limite .

A seguir serão apresentadas algumas informações e características das viagens de bicicleta e de seu usuário.

\subsubsection{Representatividade:}

Conforme dito anteriormente, a significância das viagens diárias de bicicleta na Matriz Modal do Município de São Paulo ainda não pontua, correspondendo a 0,6\% do total de viagens diárias (Gráfico 10) de acordo com a Pesquisa de Origem e Destino do Metrô de 2007.

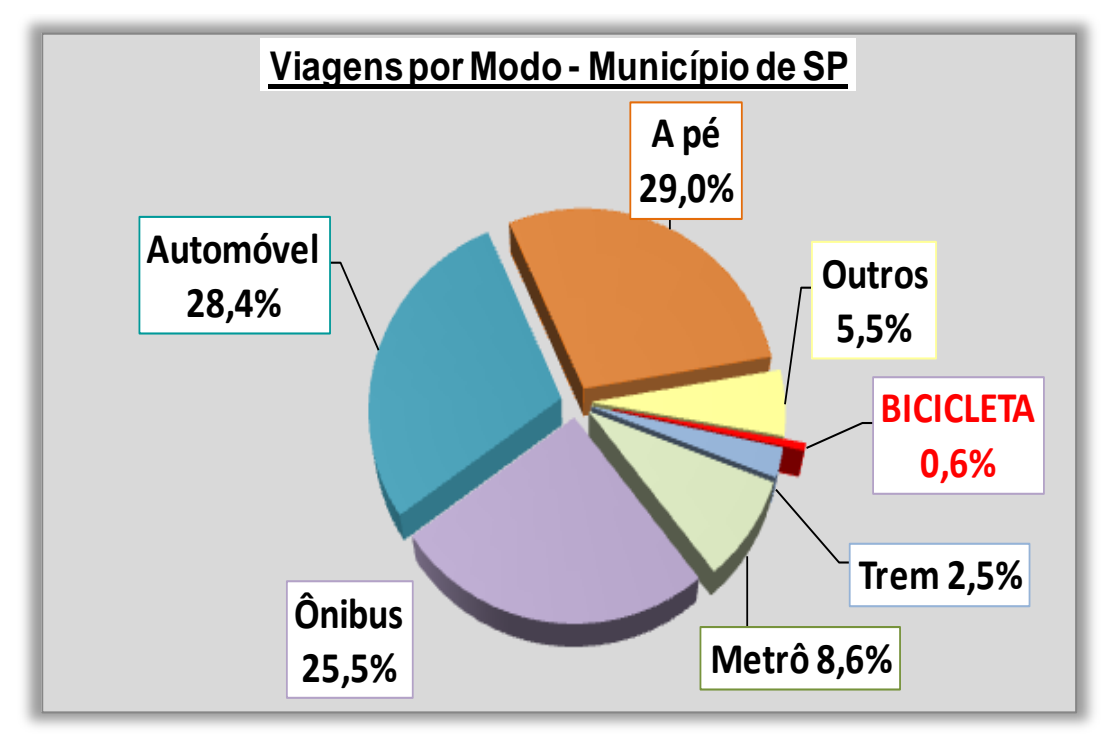

Gráfico 10- Divisão modal das viagens realizadas no Município de São Paulo - 2007 Fonte: Pesquisa de Origem e Destino do Metrô - 2007 / Elaborada pela CET- GPL/DPJ 2009

Entretanto o porcentual de viagens ciclísticas registrado pela pesquisa anterior, de 1997, correspondia a 0,3 \%do total e significou acréscimo de quase $200 \%$ ao passar de 56.398 para 156.482 viagens diárias. Também foi um dos modos de 
transporte que mais registrou subida na última década, com $183 \%$ de viagens a mais.

Outro aspecto interessante é a constatação de que a divisão modal entre os modos mais significativos (autos, a pé e transporte coletivo) permaneceu com a mesma distribuição equitativa da década precedente, conforme pode ser constatado na Tabela 2. Infelizmente o pequeno porcentual das viagens realizadas por bicicleta não permite supor ainda qual foi modo de transporte que perdeu viagens para a bicicleta. Entretanto verificando a localização geográfica da maioria das viagens de bicicletas no município, pode se relacionar esta concentração às áreas com maior deficiência de transporte público estrutural, situadas majoritariamente nas franjas da cidade.

\subsubsection{Integração da bicicleta a outros modos de transporte:}

Em 1997 ainda não haviam sido implantadas ações de integração da bicicleta com outros modos de transporte. O primeiro bicicletário vinculado a uma estação de metrô em São Paulo passou a funcionar a partir de 2006 na Estação Guilhermina Esperança da Linha Vermelha.

\begin{tabular}{|c|c|c|}
\hline Total de viagens & OD 1997 & OD 2007 \\
\hline Só Bicicleta & 56.398 & 156.482 \\
\hline Bicicleta com Metrô & - & 2.559 \\
\hline Bicicleta com Trem & 75 & 772 \\
\hline Total bicicleta & 56.473 & 159.813 \\
\hline $\begin{array}{r}\text { Total de todos os } \\
\text { modos }\end{array}$ & 21.166 .766 & 25.525 .477 \\
\hline
\end{tabular}

Tabela 8 - Registro do acréscimo das viagens realizadas por bicicleta no Município de São Paulo em 1997 e 2007 - modal único e integrado a outros modais

Fonte: Pesquisa de Origem e Destino do Metrô - 2007 / Tabulação elaborada pela CET / GPL/DPJ - 2009 
Na sequiência, o Metrô instalou sistema de bicicletas de aluguel através de parceria com a iniciativa privada, em algumas de suas estações das linhas Azul, Vermelha, Verde, com vagas também para bicicletas particulares. Apesar de estar atualmente com bicicletários desativados, esta integração foi captada pelos resultados dos dados da pesquisa (Tabela 8).

A utilização dos bicicletários das estações da CPTM, que no Município de São Paulo foram implantados após 2007 para atender aos usuários que deixavam suas bicicletas amarradas em portões e grades nas proximidades das estações, não sensibilizou a última pesaquisa OD do Metrô. Entretanto atualmente há pesquisas da CPTM $^{21}$ apontando de $80 \%$ a $100 \%$ de utilização diária para as vagas dos bicicletários das estações de Itaim Paulista e Jardim Helena (cada um com aproximadamente 250 vagas), enquanto o bicicletário da Estação Pinheiros tem ocupação em torno de $8 \%$.

\subsubsection{Localização e Densidade:}

O mapeamento do número de viagens de bicicleta por zona de origem, considerando a divisão das zonas adotadas pela Pesquisa OD de 2007, situa a maioria das viagens de bicicleta nas franjas da cidade, em regiões com características sócio - econômicas muito semelhantes. Duas delas ao Nordeste e Leste do município, apresentam topografia extremamente plana e traçado viário regular tornando-as, portanto favoráveis ao uso da bicicleta. A outra, situada ao Sul, diverge deste perfil, por ser montanhosa e de traçado viário irregular, não atrativo ao uso da bicicleta. Portanto este registro certamente reforça a indicação da grave situação de deficiência dos serviços de transporte público coletivo na região que o produz.

Estas afirmações podem ser constatadas pela visualização do Mapa 3, elaborado pela $\mathrm{CET}^{22}$, que apresenta faixas de quantidades de viagens de bicicleta por zona de origem pela Pesquisa de Origem e Destino. Este mapa dá destaque a áreas situadas na bacia do Rio Tietê e outras regiões da cidade.

\footnotetext{
${ }^{21}$ Site Cidadão SP - “Usuários dos bicicletários da CPTM aprovam o serviço" 05/07/2012

${ }^{22}$ Companhia de Engenharia de Tráfego - "Viagens de Bicicleta no Município de São Paulo - Dados Obtidos da Pesquisa de Origem e Destino - 2007" - GPL / DPJ, 2009
} 


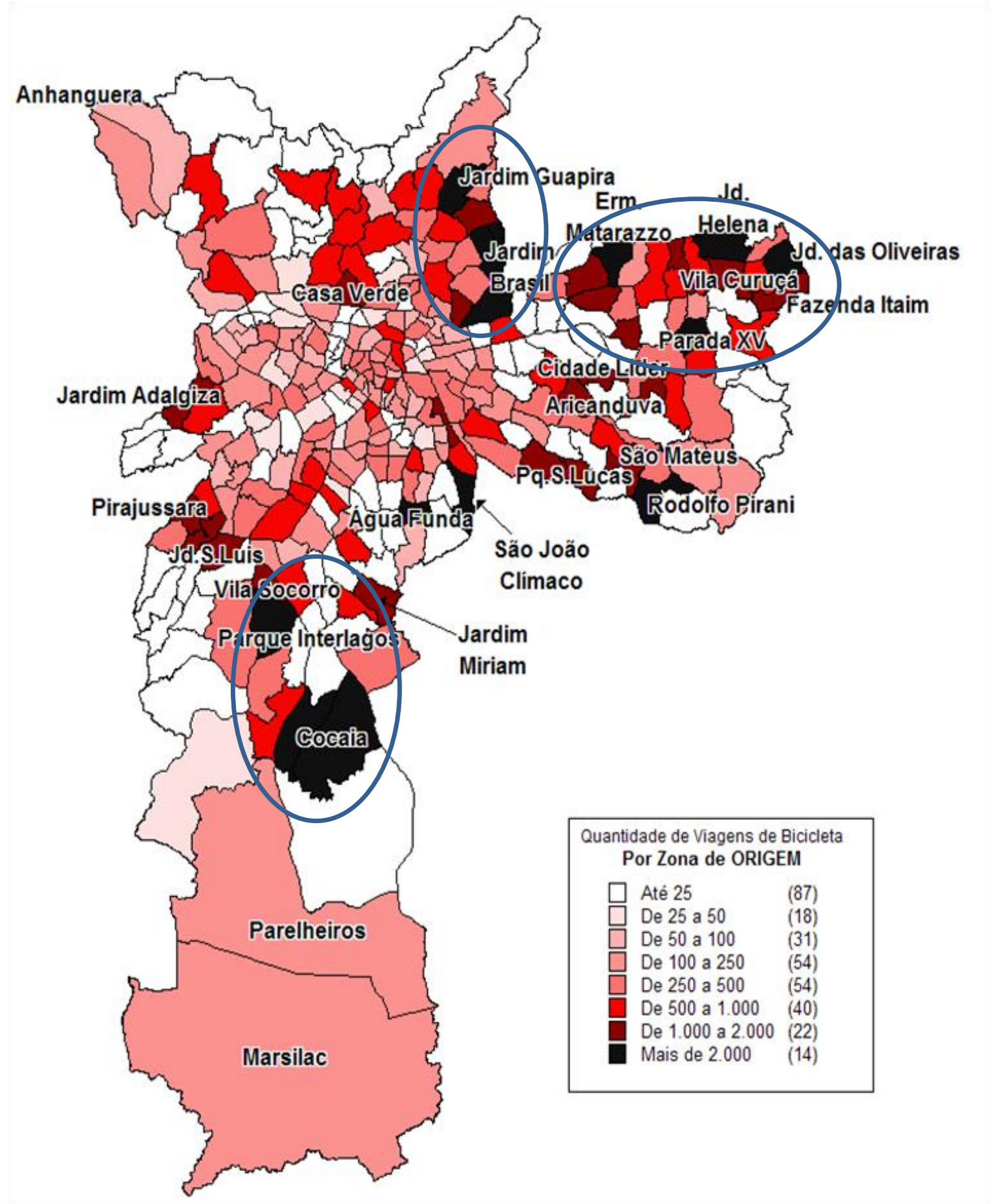

Mapa 3- Áreas onde ocorrem o maior número de viagens de bicicleta por Zona de Origem no Município de São Paulo

Fonte: Pesquisa de Origem e Destino do Metrô - 2007 / Mapa elaborado pela CET/ GPL/DPJ - 2009

Complementando e elucidando as informações contidas no Mapa 3 e no sentido de consolidar a interpretação e a confirmação das informações segue o Mapa 3.1 com as faixas de quantidades de viagens internas feitas por bicicleta nesta mesma divisão interna de área: 


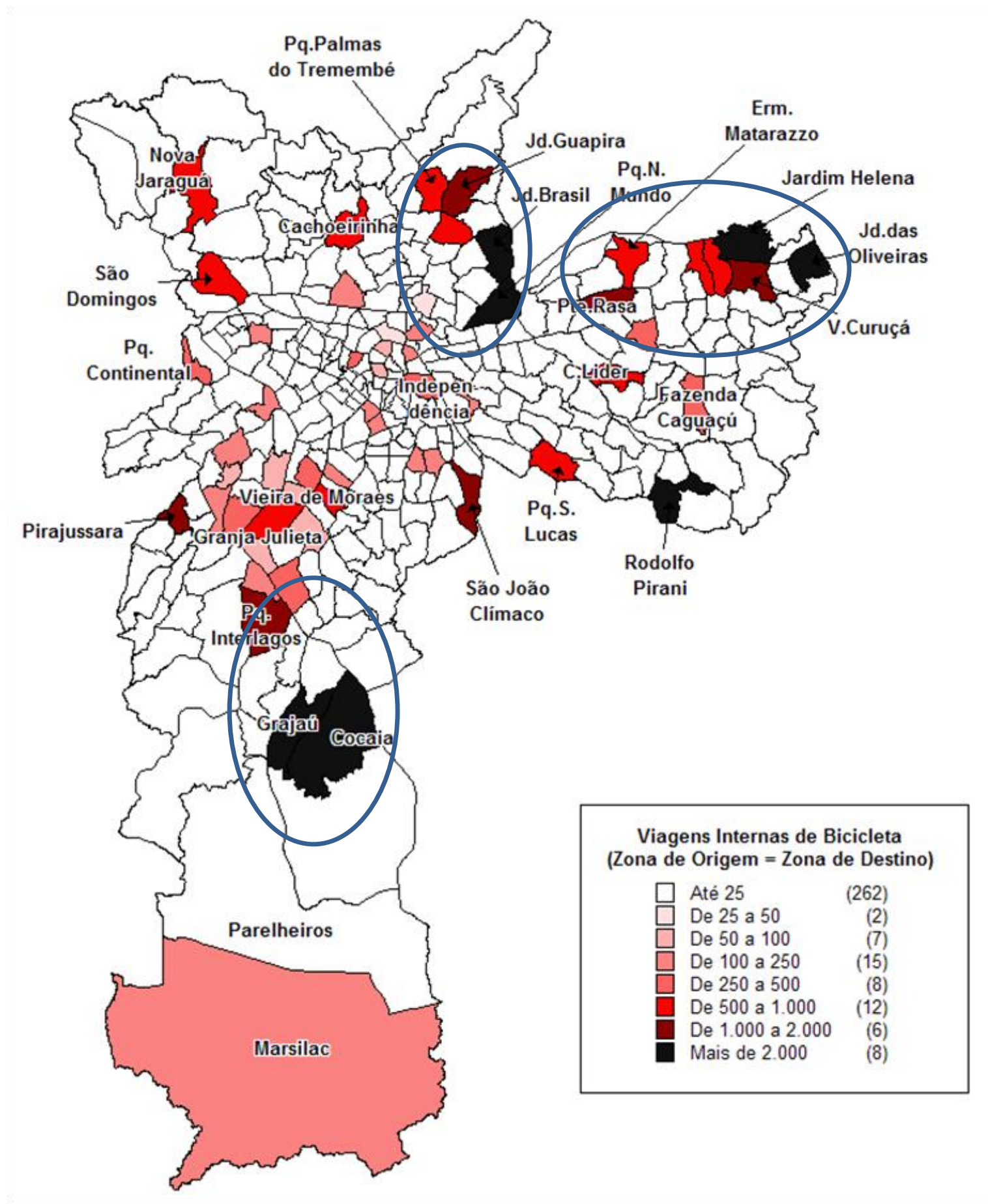

Mapa 4.1- Áreas onde ocorrem o maior número de viagens internas de bicicleta por Zona de Origem = Zona de Destino no Município de São Paulo

Fonte: Pesquisa de Origem e Destino do Metrô - 2007 / Mapa elaborado pela CET/ GPL/DPJ - 2009

Nestes dois mapas fica claro o destaque de três mesmas áreas do município com maior registro de viagens feitas por bicicletas.

Uma delas, área situada a Nordeste, trata-se de região-dormitório, onde a população moradora dos bairros Jardim Brasil e Jardim Guapira trabalha nas indústrias do município vizinho, Guarulhos, e realiza também internamente 
suas atividades cotidianas de bicicleta, inclusive para frete e carreto. A pouca distância entre destinos certamente é fator definidor da escolha do veículo. Por outro lado, cabe destacar a inexistência de integração ao transporte estrutural nesta região como trem ou metrô: a estação mais próxima, Tucuruvi da Linha Azul do Metrô, situa-se a uma distância superior ao padrão da viagem ciclística ( de 3 a $5 \mathrm{Km}$ ) e até o momento não possui bicicletário.

A outra região situada a Leste compreende os bairros de Ermelino Matarazzo, São Miguel, Jardim Helena e Itaim Paulista, que também são bairros-dormitório, mas com centralidades de comércio e serviços locais mais intensificados.

Estes bairros são servidos pela Linha Safira da CPTM, cujos bicicletários de uso gratuito com mais de duzentas vagas cada um, lotam nas primeiras horas da manhã ${ }^{23}$, e produzem oferta informal extra deste tipo de serviço, com cobrança de tarifa, no interior de edificações próximas às estações. Nesta região, ao contrário do que acontece na maior parte da cidade, é muito comum observar mulheres, inclusive senhoras, utilizando bicicleta para suas atividades cotidianas de levar filhos à escola ou fazer compras. Também existe troca de viagens com o município vizinho Guarulhos em decorrência da continuidade da mancha urbana e as atividades a ela relacionadas.

Finalmente, a terceira destas regiões, situada a Sul compreende os bairros de Grajaú e Cocaia, apresenta topografia extremamente acidentada e malha viária limitada, irregular, densamente ocupada pelo tráfego motorizado, com linhas de ônibus integradas ao Terminal SPTrans Grajaú e à Estação Grajaú da Linha Turquesa da CPTM. Como único acesso às regiões mais longínquas situadas ao extremo Sul da cidade, o serviço de ônibus conta com a Av. Belmira Marin. Por falta de alternativa é nesta via que se concentra também o maior número de viagens de bicicleta, em situações extremas de desconforto e risco, e explicadas, obviamente, pela limitada condição de mobilidade oferecida pelos sistemas de transporte coletivo que operam na região.

Em todas elas, a densidade de viagens de bicicleta geradas é a mesma, situandose na faixa entre 2 a 5 mil viagens de bicicleta por dia; em algumas áreas superando 5 mil o número de viagens diárias.

${ }^{23}$ Site Cidadão SP - “Usuários dos bicicletários da CPTM aprovam o serviço” 05/07/2012 


\subsubsection{Caracterização das viagens externas às zonas de origem}

Os mapas a seguir também elaborados pela $\mathrm{CET}^{24}$ apresentam o número de viagens de bicicleta que extrapolam suas zonas de origem situadas no município de São Paulo, e que representam $66 \%$ do total de viagens de bicicleta do município, muitas das quais situadas em zonas não destacadas no Mapa 3.

De forma geral o registro das trocas de viagens entre bairros diferentes da cidade, na maioria delas ocorre entre áreas vizinhas e algumas vezes em extensões de viagem que extrapolam o padrão médio da escala do deslocamento ciclístico que é de 3 a $5 \mathrm{Km}$.

Os mapas a seguir, repetidamente apontam a busca de solução paliativa através do uso da bicicleta para a má qualidade dos serviços de transporte público de forma geral, fica constatado principalmente o não atendimento da demanda de deslocamento perimetral entre bairros vizinhos ou próximos, muitas vezes não servidos pela atual rede de ônibus.

O Mapa 4 aponta regiões de maior concentração de troca de viagens de bicicleta entre zonas diferentes (mais de 500 viagens / dia) , algumas em municípios vizinhos da região metropolitana. Nota-se que esta situação ocorre somente nas duas regiões paulistanas onde que mais se utiliza a bicicleta já apresentadas no Mapa 3 e 3.1, que são região Nordeste e Leste.

No restante dos mapas, a troca de viagens ocorre entre bairros próximos, destacando-se a demanda radial entre bairros da região Sudeste e a área de influência da Av. Paulista e outra entre a região Nordeste e bairros de Santana e Casa Verde.

O Mapa 5 com a próxima faixa decrescente de viagens de bicicleta em zonas diferentes, repete a característica de troca entre bairros vizinhos, porém destaca outras regiões da cidade de menor intensidade de uso diário deste veículo. Também nesta faixa de viagens foram registrados alguns deslocamentos cuja escala supera o padrão característico da viagem de bicicleta, apontando uma conexão metropolitana entre municípios de Osasco de Barueri à região Sudeste do município (Ipiranga e Sacomã).

\footnotetext{
${ }^{24}$ Companhia de Engenharia de Tráfego - "Viagens de Bicicleta no Município de São Paulo - Dados Obtidos da Pesquisa de Origem e Destino - 2007" - GPL / DPJ, 2009
} 


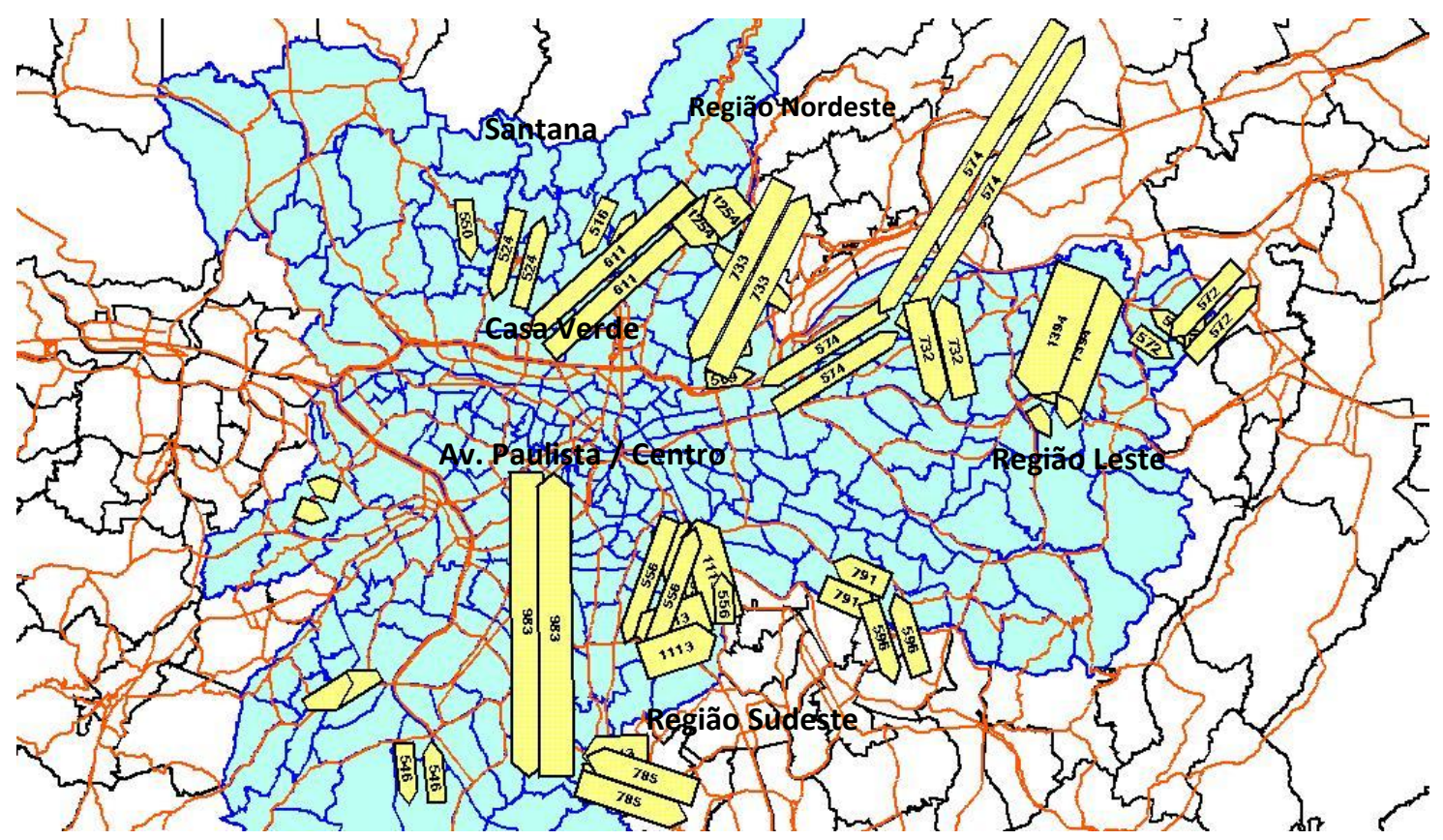

Mapa 5 - Deslocamentos com mais de 500 viagens externas / dia de bicicleta - Zonas de Origem diferentes das Zonas de Destino

Fonte: Pesquisa de Origem e Destino do Metrô - 2007 / Mapa elaborado pela CET/ GPL/DPJ - 2009

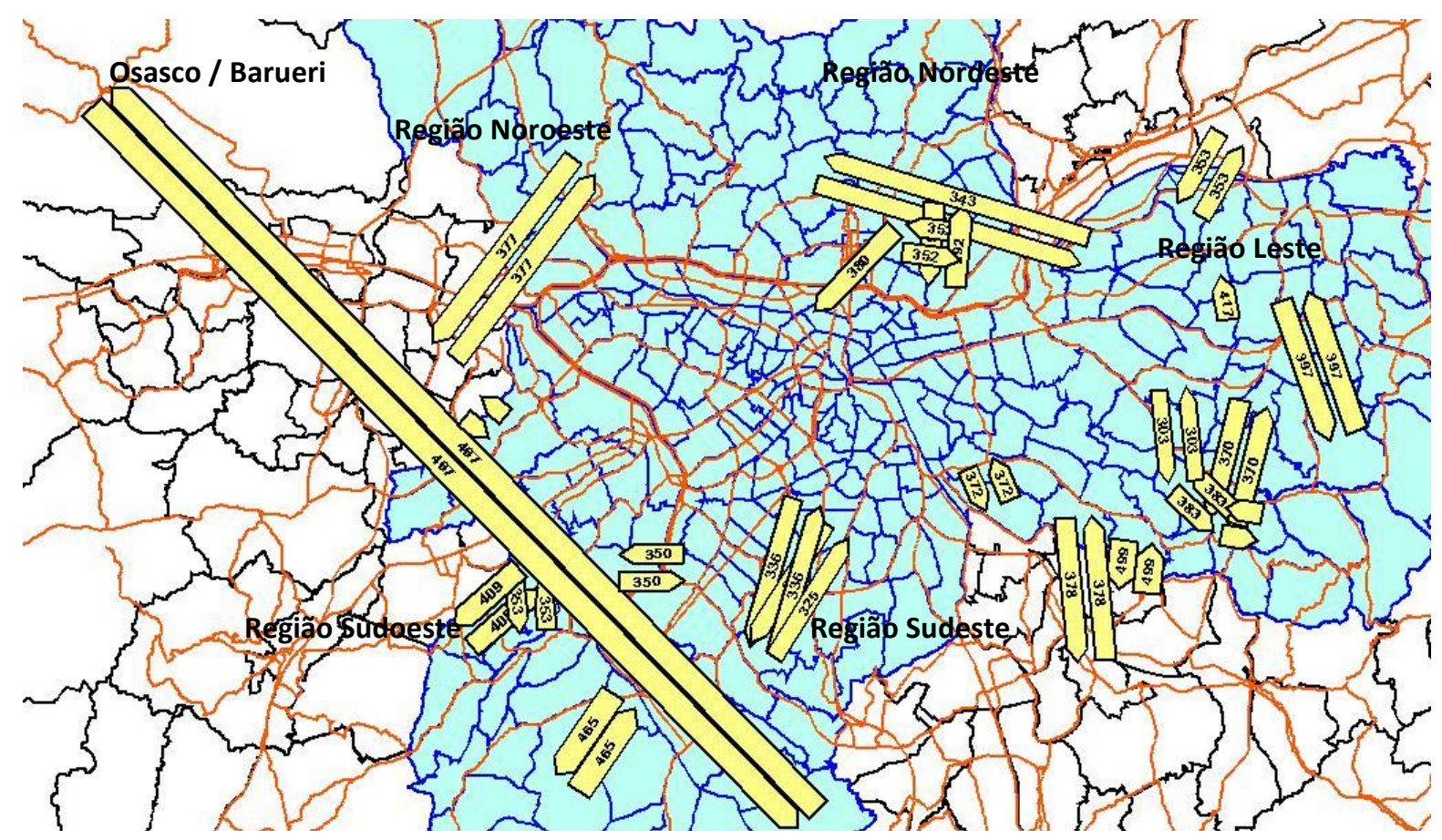

Mapa 6 - Deslocamentos com 300 a 500 viagens externas / dia de bicicleta - Zonas de Origem diferentes das Zonas de Destino

Fonte: Pesquisa de Origem e Destino do Metrô - 2007 / Mapa elaborado pela CET/ GPL/DPJ - 2009

Extensão: Escala aproximada: $2 \mathrm{Km}$ 


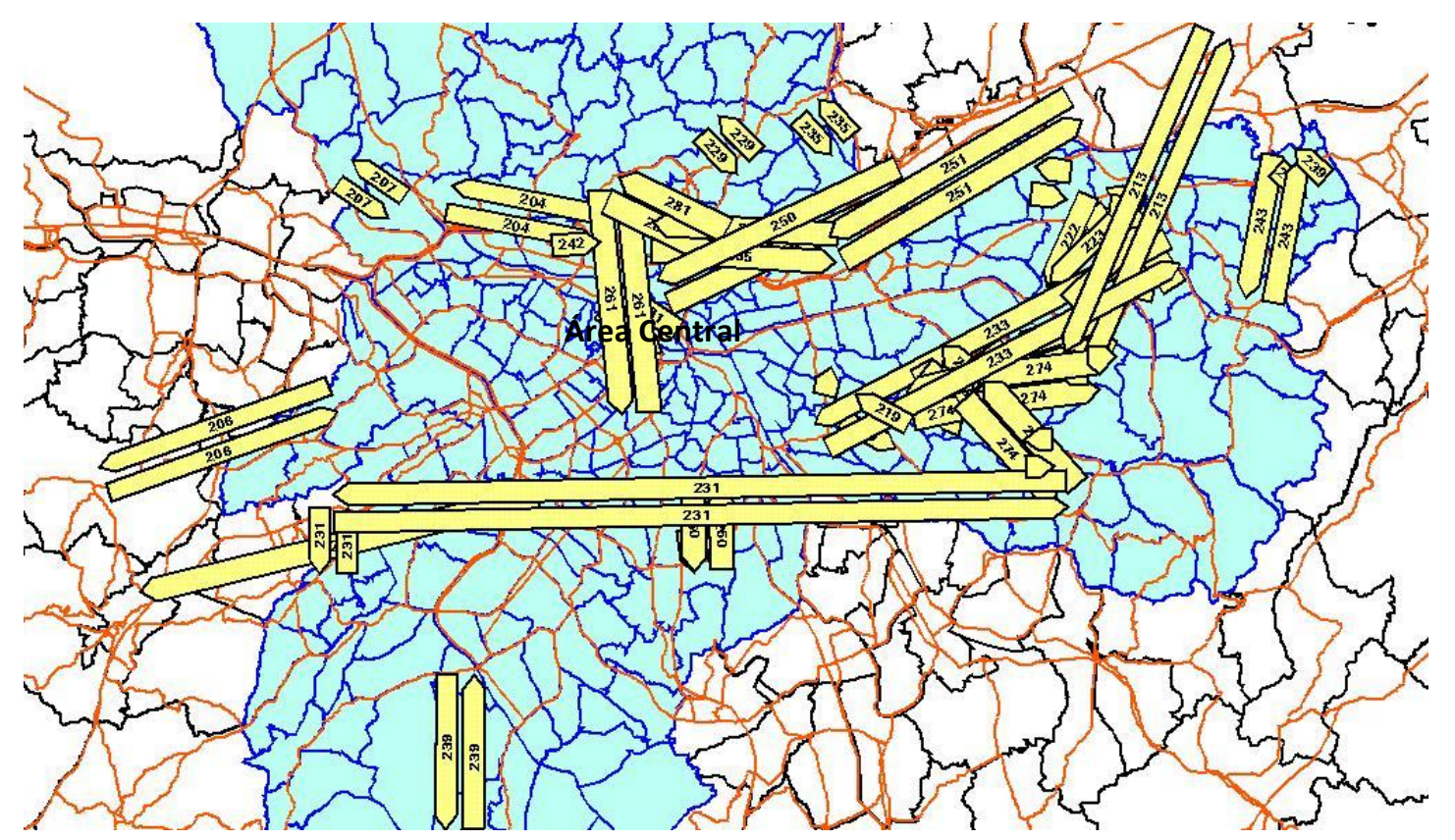

Mapa 7 - Deslocamentos com 200 a 300 viagens externas / dia de bicicleta - Zonas de Origem diferentes das Zonas de Destino

Fonte: Pesquisa de Origem e Destino do Metrô - 2007 / Mapa elaborado pela CET/ GPL/DPJ - 2009

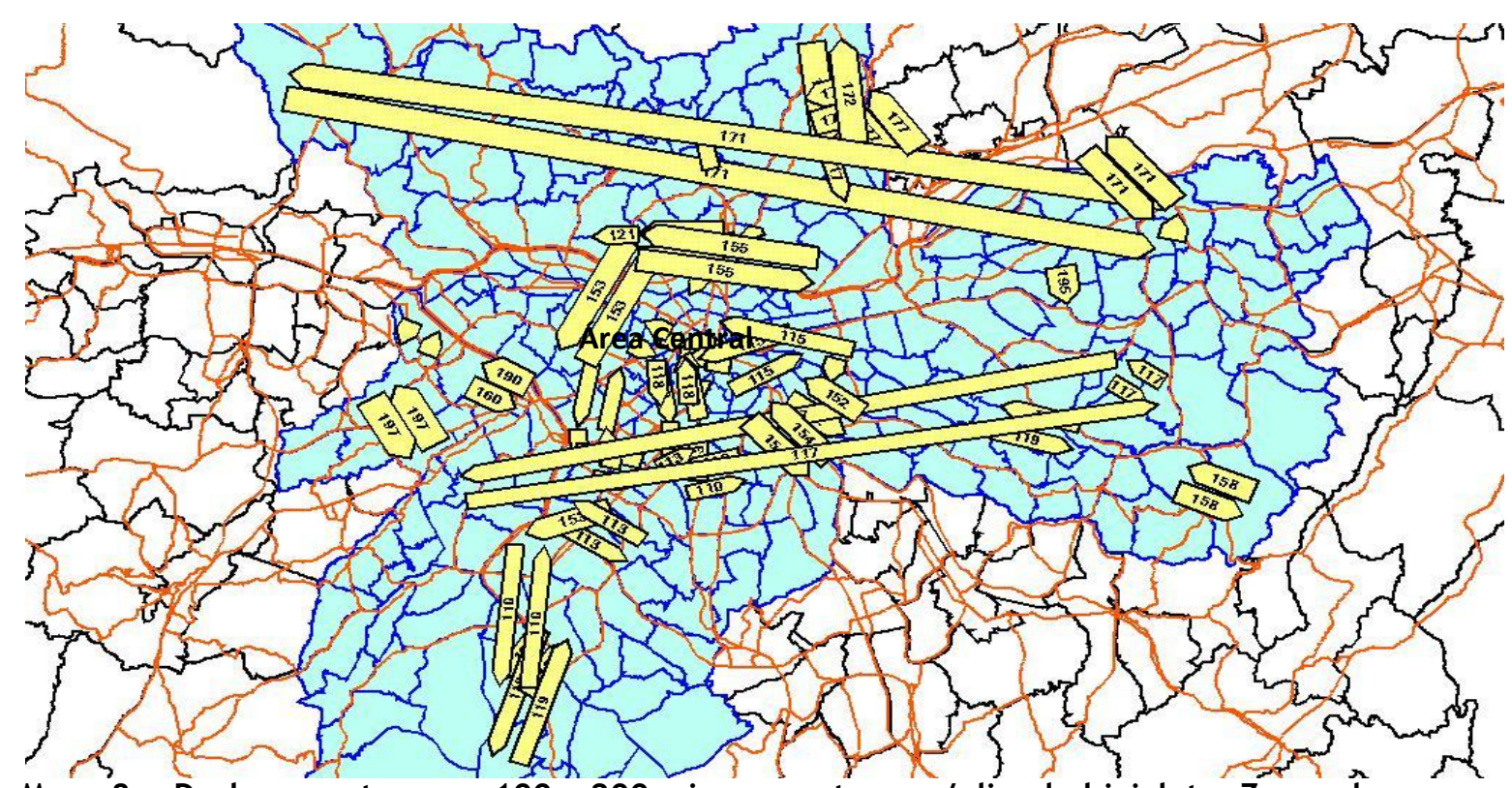

Mapa 8 - Deslocamentos com 100 a 200 viagens externas / dia de bicicleta-Zonas de Origem diferentes das Zonas de Destino

Fonte: Pesquisa de Origem e Destino do Metrô - 2007 / Mapa elaborado pela CET/ GPL/DPJ - 2009

Extensão: Escala aproximada: $2 \mathrm{Km}$

Por outro lado, mais uma vez reforçando a constatação de fuga da má qualidade do transporte, nota-se que o registro do uso cotidiano da bicicleta nas áreas da 
cidade mais bem servidas pelos sistemas de transporte. Estão em sua maioria situada nos bairros imediatos à Área Central ocorrendo nas faixas inferiores a 200 viagens/dia (Mapas 6 e 7).

Nestas áreas as viagens de bicicleta se caracterizam por longos percursos perimetrais Leste-Oeste em bairros vizinhos à Área Central, além da ligação dos bairros da periferia aos bairros centrais onde se concentra a maior oferta de empregos.

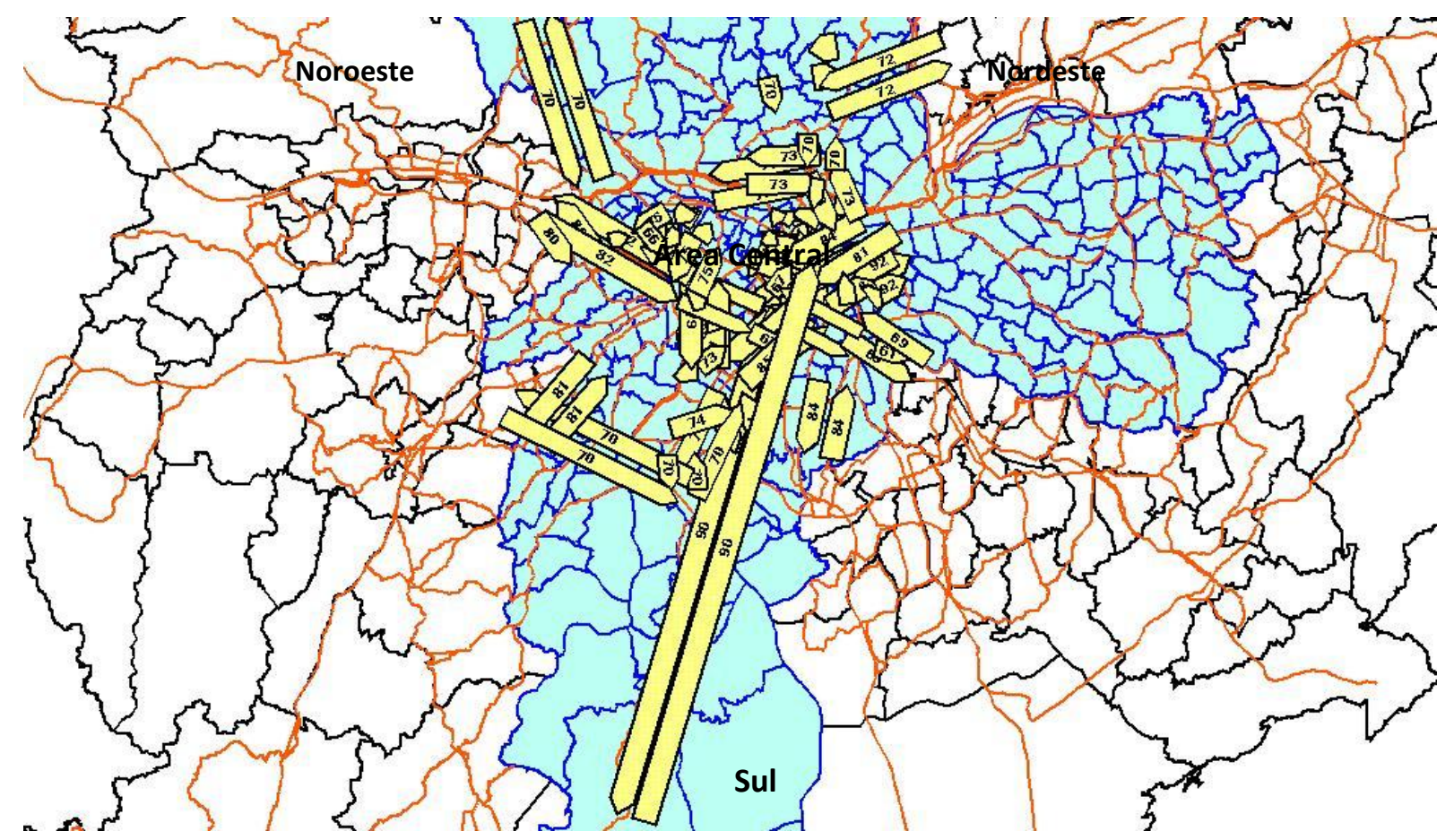

Mapa 9 Deslocamentos com 50 a 100 viagens externas / dia de bicicleta - Zonas de Origem diferentes das Zonas de Destino

De 50 a 100 viagens por dia

Fonte: Pesquisa de Origem e Destino do Metrô - 2007 / Mapa elaborado pela CET/ GPL/DPJ - 2009

Finalmente o Mapa 8, registra os itinerários com o menor número de viagens ciclísticas diárias, expõe grande concentração de pequenas viagens apontadas ao centro do município e bairros centrais e três grandes deslocamentos nos vetores Sul, Noroeste e Nordeste.

\subsubsection{Extensão das viagens de bicicleta:}

Em relação à extensão das viagens, conforme nos mostra os Gráfico 11 e 12, a maioria delas (81\%) está na faixa entre 1 e 6 Km (89 \%), dentro das 
características padrão para viagens ciclísticas, onde a distância pode dispensar o uso do transporte público mas é desestimulante para ser percorrida a pé.

A comparação da tabela mencionada com os mapas apresentados no item anterior (3.2.4.), leva a concluir que a maioria das viagens com destino fora da zona de origem concentra-se no padrão de distância de até $5 \mathrm{Km}$, e indicação para as viagens com integração modal por bicicletários os porcentuais relacionados às distâncias maiores.

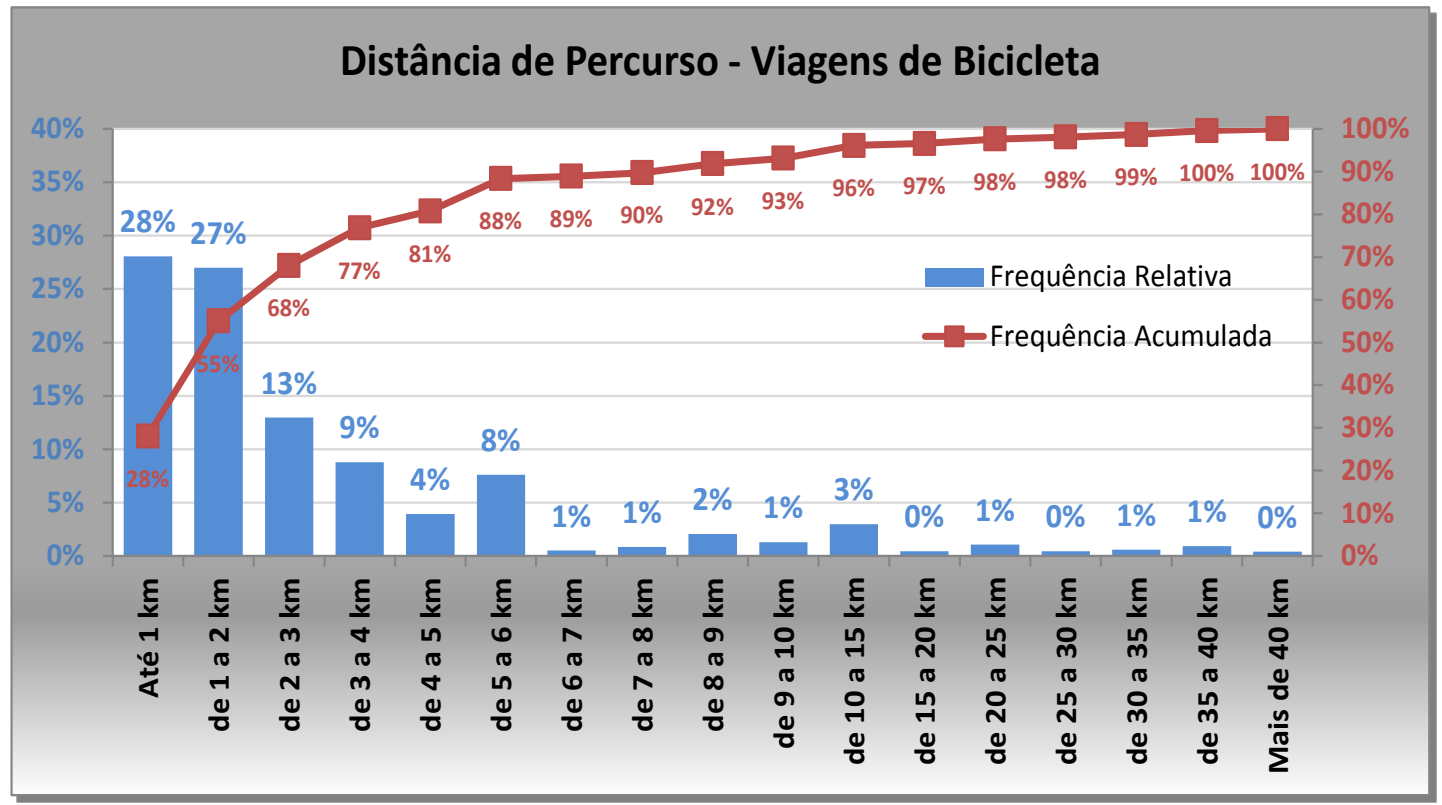

Gráfico 11- Distância de percurso das viagens de bicicleta no município São Paulo Fonte: Pesquisa de Origem e Destino do Metrô - 2007 Gráfico elaborado por Gláucia G. Pereira

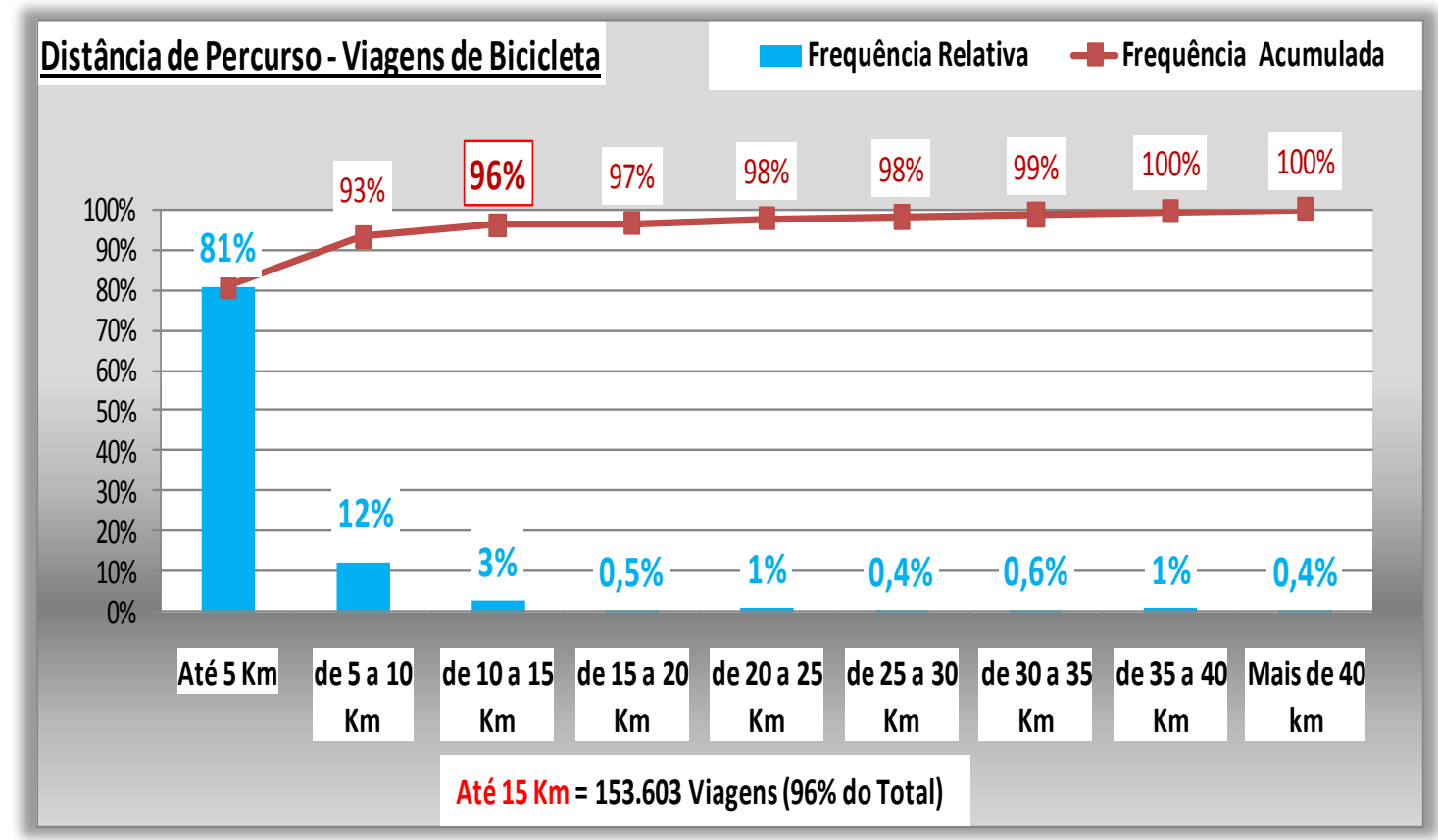

Gráfico 12 - Distância de percurso das viagens de bicicleta no município São Paulo faixas concentradas

Fonte: Pesquisa de Origem e Destino do Metrô - 2007 / Companhia de Engenharia de Tráfego - GPL/ DPJ - 2009 


\subsubsection{Duração das viagens de bicicleta:}

A duração das viagens de bicicleta exposta no Gráfico 13 é reflexo da extensão delas resultando, portanto, em sua maioria na faixa dos 30 minutos, já que a velocidade média da bicicleta é 15 a $20 \mathrm{Km} / \mathrm{h}$.

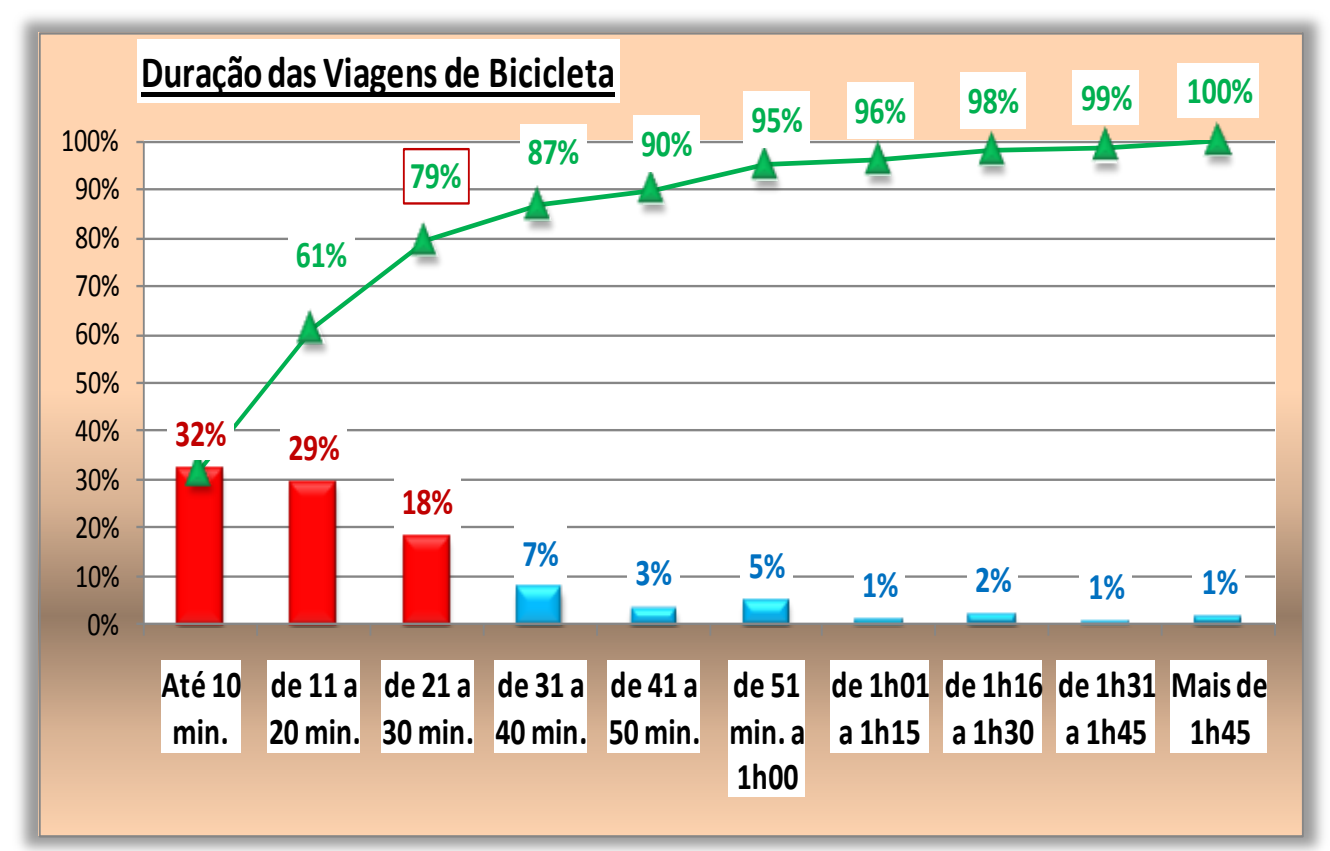

Gráfico 13 - Duração das viagens de bicicleta no Município de São Paulo

Fonte: Pesquisa de Origem e Destino do Metrô - 2007 / Companhia de Engenharia de Tráfego / GPL 2009

Este dado reforça a constatação dos padrões de extensão da maioria destas viagens mostrado nos gráficos anteriores, 11 e 12, valendo a pena ressaltar que o gasto de cerca de meia hora do tempo diário do deslocamento, certamente é muito inferior ao tempo que seria despendido pelo uso dos sistemas de transporte disponíveis nestas regiões, considerando nesta conclusão, o tempo de espera também.

\subsubsection{Motivos da viagem de bicicleta:}

Os motivos das viagens por bicicleta mostrados no Gráfico 14 e Tabela 9 são em sua maioria utilitários e neste segmento, o motivo principal é Trabalho com a maior parte realizada pelo prestador de serviços, seguido pelo trabalhador da indústria e o trabalhador do comércio. Outros motivos utilitários que aparecem são sempre vinculados à atividades realizadas geralmente em locais próximos à residência como Assuntos Pessoais e Compras. 
O motivo Educação aparece em segundo lugar, apontando para o potencial do transporte por bicicleta de estudantes e o que isto significa quanto à ações de educação de trânsito e segurança do ciclista, principalmente o da faixa etária menor, pois não há especificação de restrição de idade para o uso da bicicleta.

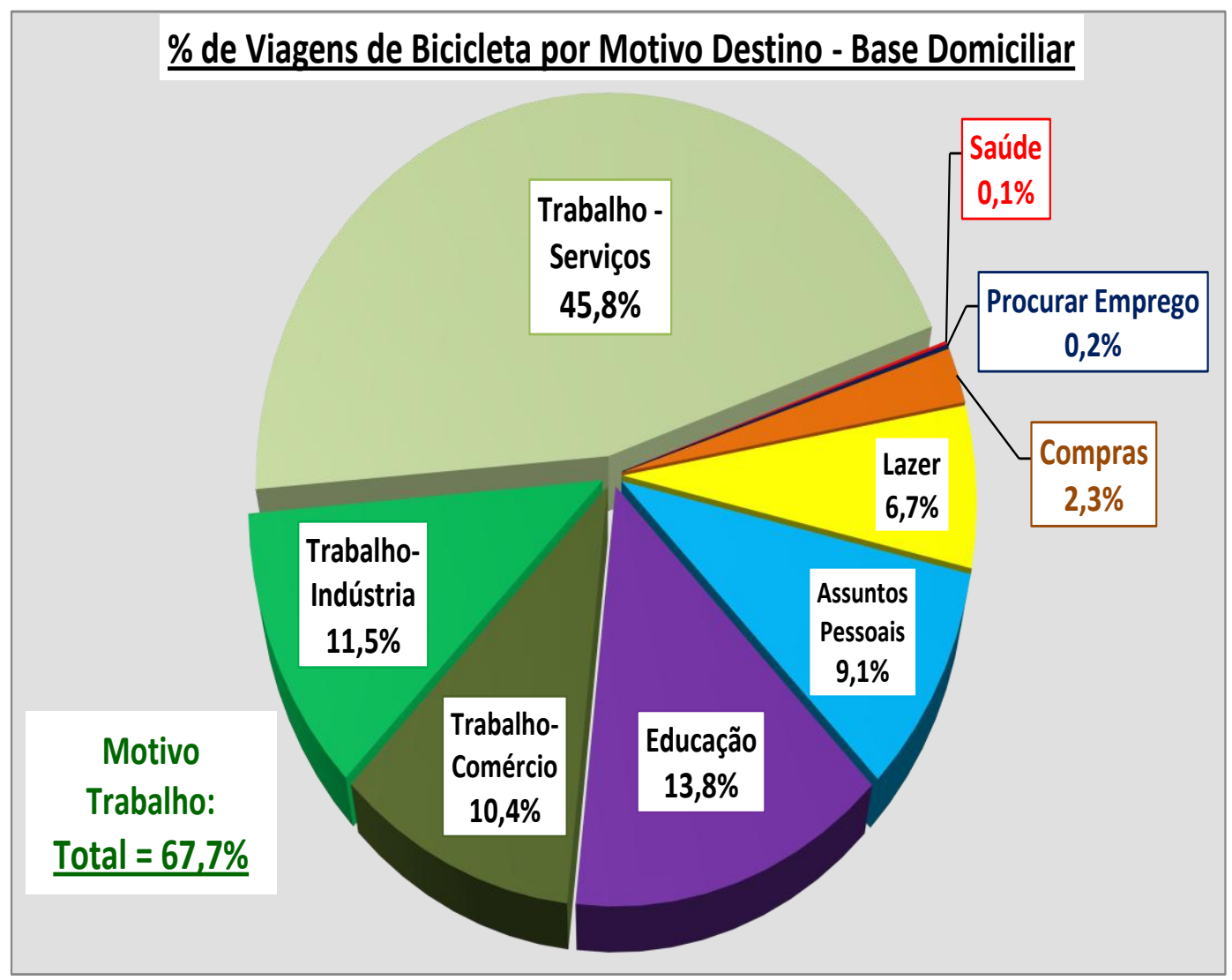

Gráfico 14 - Motivo das viagens de bicicleta no Município de São Paulo

Fonte: Pesquisa de Origem e Destino do Metrô - 2007 / Companhia de Engenharia de Tráfego / GPL 2013

A Tabela 9 que apresenta os motivos das viagens relacionados aos distritos onde ocorrem confirmam o motivo Trabalho como principal seguido pelo motivo Educação. Cabe lembrar que à exceção dos bairros do Itaim-Bibi, Ipiranga e Casa Verde, a maioria dos bairros listados nesta planilha estão situado nas regiões de periferia da cidade. 


\begin{tabular}{|c|c|c|c|c|c|}
\hline $\begin{array}{l}\text { Distrito } \\
\text { Origem }\end{array}$ & Trabalho & $\begin{array}{r}\text { Escola/ } \\
\text { Educação }\end{array}$ & $\begin{array}{c}\text { Lazer/ } \\
\text { Recreação }\end{array}$ & $\begin{array}{r}\text { Outros } \\
\text { (Saúde/Assuntos } \\
\text { Pessoais) }\end{array}$ & Total \\
\hline Grajaú & 3.910 & 0 & 0 & 5.541 & 9.451 \\
\hline Vila Maria & 7.562 & 196 & 504 & 504 & 8.767 \\
\hline Jd. Helena & 6.123 & 0 & 1.370 & 694 & 8.187 \\
\hline Jaçanã & 3.020 & 3.926 & 0 & 172 & 7.118 \\
\hline Vila Medeiros & 3.227 & 1.838 & 0 & 920 & 6.035 \\
\hline Tremembé & 3.594 & 1.249 & 0 & 172 & 5.015 \\
\hline Itaim Paulista & 2.011 & 0 & 2.945 & 0 & 4.956 \\
\hline Campo Limpo & 1.599 & 2.444 & 0 & 445 & 4.488 \\
\hline Sacomã & 2.771 & 1.108 & 0 & 0 & 3.879 \\
\hline Socorro & 2.215 & 117 & 233 & 755 & 3.320 \\
\hline São Mateus & 2.530 & 763 & 0 & 0 & 3.292 \\
\hline Cursino & 1.758 & 1.108 & 0 & 375 & 3.242 \\
\hline Ipiranga & 2.124 & 824 & 92 & 46 & 3.086 \\
\hline $\begin{array}{l}\text { Cidade } \\
\text { Ademar }\end{array}$ & 2.870 & 0 & 0 & 0 & 2.870 \\
\hline Itaquera & 2.576 & 0 & 0 & 290 & 2.867 \\
\hline Itaim Bibi & 1.886 & 382 & 237 & 56 & 2.561 \\
\hline $\begin{array}{l}\text { Erm. } \\
\text { Matarazzo }\end{array}$ & 2.302 & 0 & 0 & 0 & 2.302 \\
\hline Casa Verde & 1.735 & 194 & 241 & 40 & 2.211 \\
\hline São Rafael & 2.182 & 0 & 0 & 0 & 2.182 \\
\hline Sapopemba & 1.588 & 582 & 0 & 0 & 2.170 \\
\hline S. Miguel Pta. & 1.694 & 0 & 0 & 340 & 2.034 \\
\hline
\end{tabular}

Tabela 9 - Motivo das viagens para distritos que produzem mais de 2000 viagens/dia Fonte: Relatório “O Uso de Bicicletas na Região Metropolitana de São Paulo” Metrô-2007

\subsubsection{Razões da opção ao uso da bicicleta:}

O Gráfico 15 expõe as justificativas alegadas pelos usuários da bicicleta paulistanos em deslocamentos diários.

De acordo com os dados apresentados neste gráfico, o principal motivo apontado é a proximidade do destino em relação à residência, característica esta já constatada anteriormente pelos Gráficos 9 e 10 , confirmando assim que a bicicleta é o recurso utilizado por quem busca uma forma mais eficiente de transporte para os pequenos deslocamentos.

A segunda justificativa está relacionada ao custo do transporte confirmando que seu peso para o usuário ainda é considerável, mesmo com a introdução de políticas inclusivas de tarifa como o Bilhete Único, adotado no município desde 2004. Cabe ressaltar que no município de São Paulo se reproduz, na mesma escala de prioridade, os motivos alegados na RMSP (Tabela 5 e Gráfico 8), 
destacando o fato do bilhete Único não ser ainda extensivo ao transporte metropolitano sobre pneus. A integração com os modos de transporte sobre trilhos (metrô e trem), apesar de haver integração, apresenta incidência de tarifa extra de $R \$ 1,65$ sobre os $R \$ 3,00$ já pagos anteriormente.

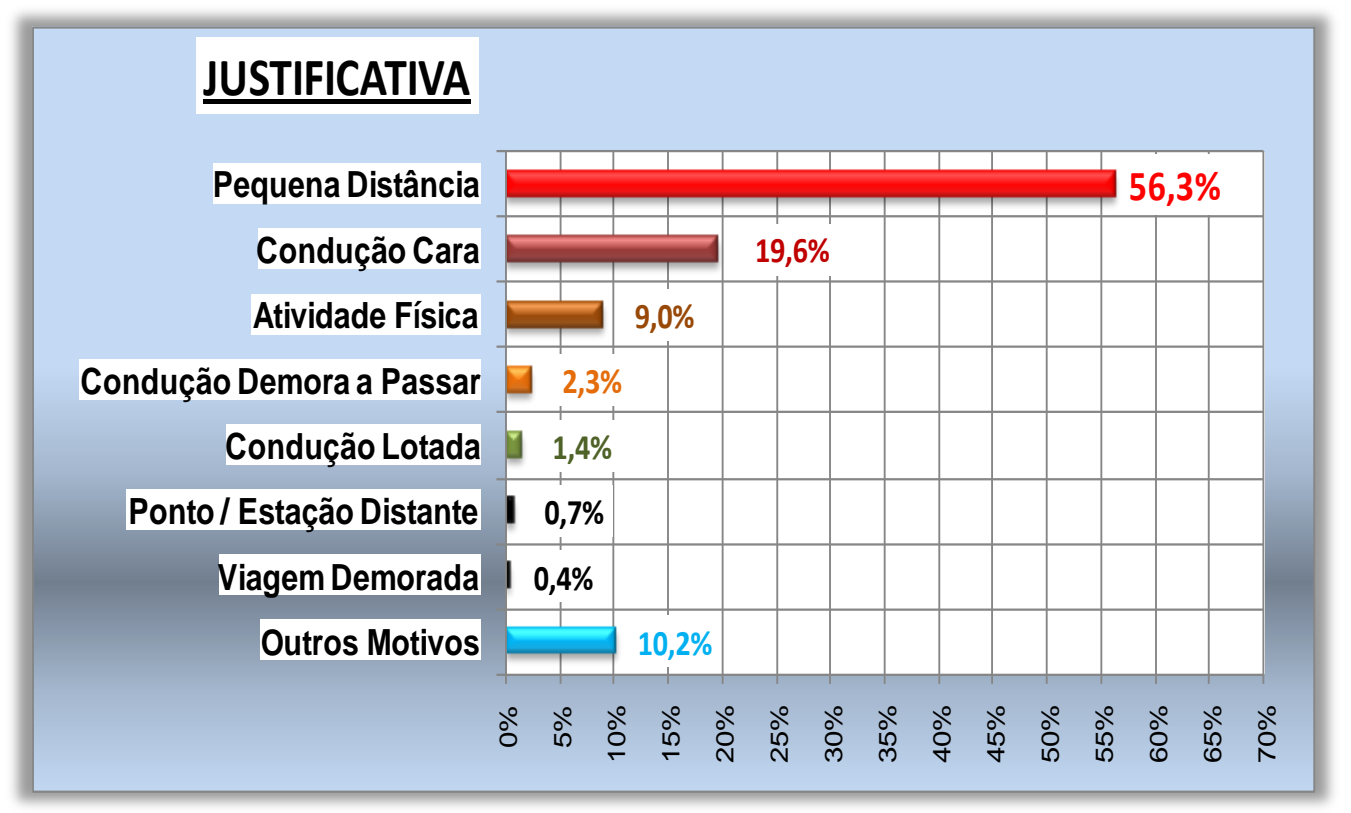

Gráfico 15 - Justificativas de uso da bicicleta nas viagens diárias no município de São Paulo

Fonte: Pesquisa de Origem e Destino do Metrô - 2007 / Companhia de Engenharia de Tráfego / GPL 200

Convém relacionar os dados desta tabela aos apresentados pela Tabela 7, que destacou a quase total maioria das viagens de bicicleta no Município de São Paulo realizadas com pouca integração aos sistemas de transporte. Certamente também conta, como já mencionado anteriormente, a não existência de facilidades de integração representadas pelos bicicletários da CPTM ainda em pequeno número na ocasião da realização da pesquisa.

\subsubsection{A bicicleta de carga e o bicifrete}

Apesar da falta de dados específicos sobre o uso da bicicleta de carga para entrega observa-se cada vez mais sua utilização em algumas regiões do município de São Paulo, principalmente na Área Central e seu calçadão ${ }^{25}$ para entrega de documentos, água e alimentos. Em outras regiões próximas ao Centro como o Bom Retiro e Bras é comum o uso de bicicletas cargueiras para

\footnotetext{
${ }^{25}$ É permitido a bicicleta circular no calçadão porque o Código de Trânsito Brasileiro só proíbe a entrada de veículos motorizados, salvo os de emergência e os permitidos em horários pré definidos - Nota da autora.
} 
transporte de mercadorias de pequeno porte como aviamentos utilizado pelas várias confecções de vestuário ali situadas. Também é usual observar o uso da bicicleta para entrega de padarias, açougues e lanchonetes em pontos diversos da cidade e algumas empresas de supermercados tem até frota própria.
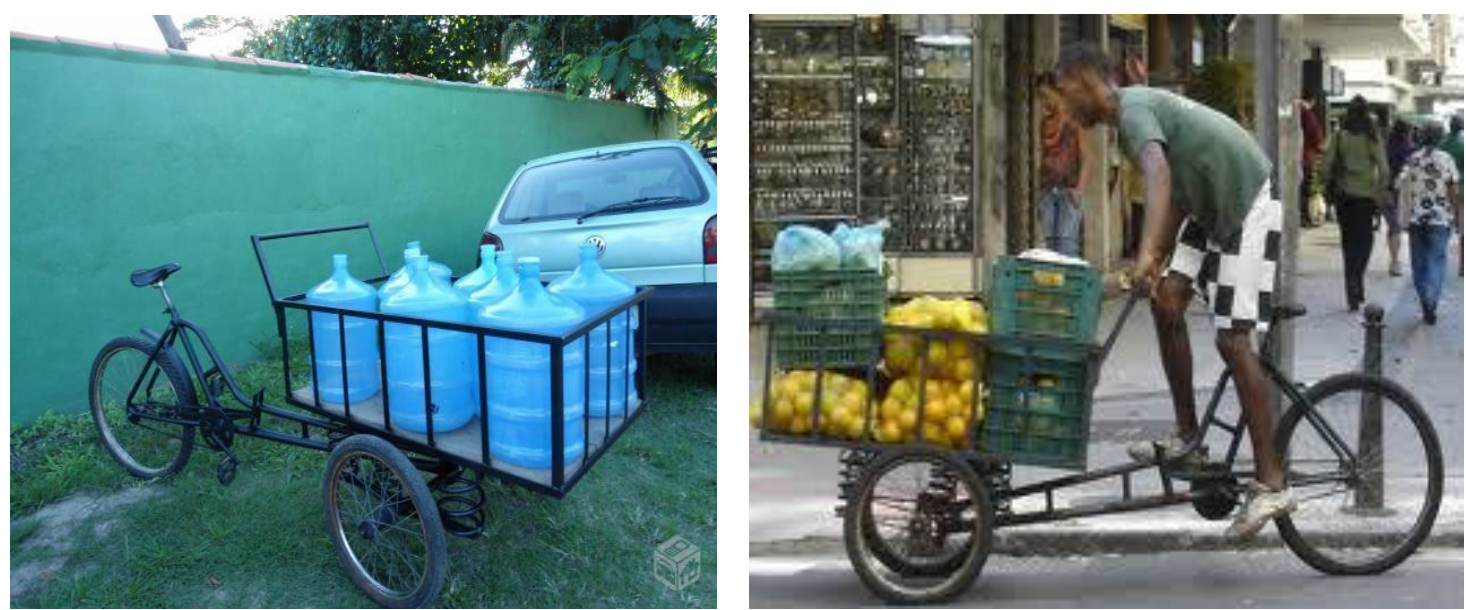

Foto 1 e Foto 2 Bicicletas para entrega de água e mercadorias comuns na Área Central de SP Fotos: Arquivo Blog Curiocidade - Estadão
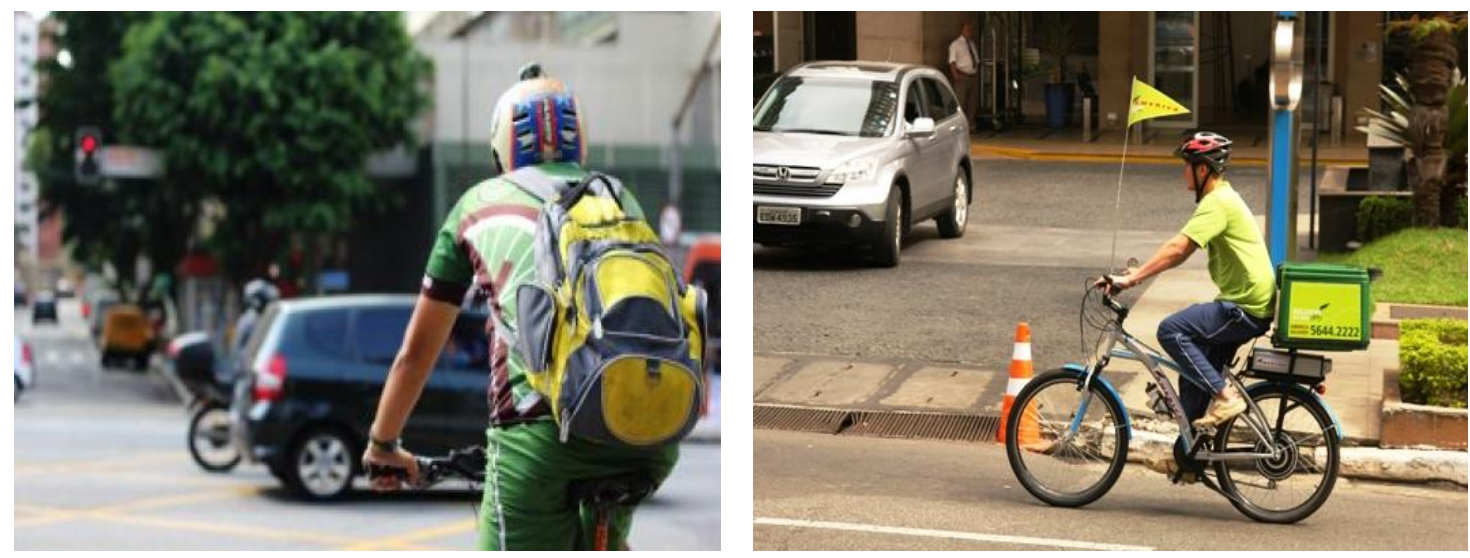

Foto 3 e Foto 4 Bicicletas para entrega de documentos e lanches Fotos: Arquivo Blog Curiocidade - Estadão 


\subsection{Os usuários de bicicleta - perfil sócio econômico:}

O desafio representado pelo grau de dificuldade do uso diário da bicicleta no sistema viário do Município de São Paulo acaba por definir o perfil do usuário cotidiano da bicicleta. Resumidamente: ele é jovem, do sexo masculino, faixa de renda baixa e utiliza a bicicleta para o deslocamento casa-trabalho-casa, majoritariamente como modal único e em menor número, integrado com outro modo de transporte.

\subsubsection{Gênero do ciclista cotidiano:}

A alta representatividade do sexo masculino (90\%) nas viagens de bicicleta, conforme mostrado no Gráfico 16, é reflexo direto das características físicas e psicológicas requeridas para seu uso, que exigem vigor físico, resistência à pressão psicológica, e maior aceitação a situações de risco, já que São Paulo não dispõe até o momento de uma rede cicloviária adequada. Entretanto, mesmo neste cenário tem sido observada, ultimamente, a cada vez maior presença feminina jovem utilizando diariamente bicicleta.

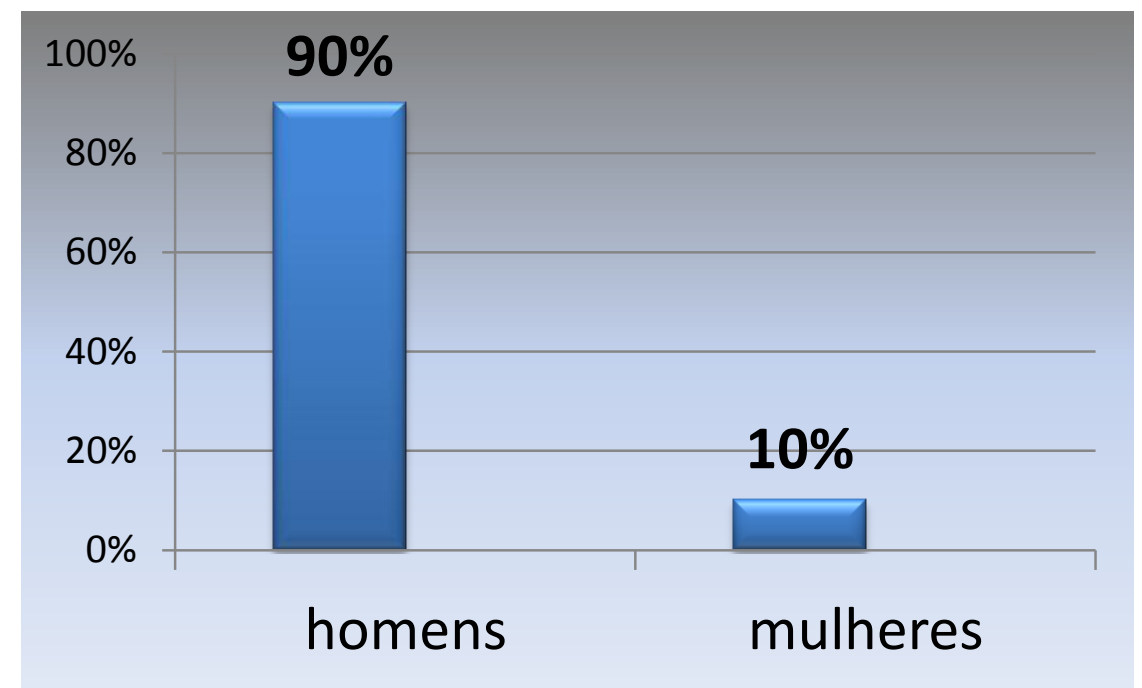

Gráfico 16 - Usuário diário da bicicleta por gênero

Fonte: Pesquisa de Origem e Destino do Metrô - 2007 / CET / GPL/ DPJ - 2009 


\subsubsection{Faixa etária do ciclista cotidiano:}

O Gráfico 17 permite consolidar o perfil etário do usuário diário da bicicleta, apontando uma alta a partir dos 16 anos, quando o estilo de vida passa a exigir maior autonomia nos deslocamentos. Permanece num patamar uniforme até os 30 anos. A partir daí ocorre um fenômeno interessante de queda de usuários ciclistas na faixa dos 31 aos 35 anos para uma subida ainda maior na faixa dos 36 aos 40 anos.

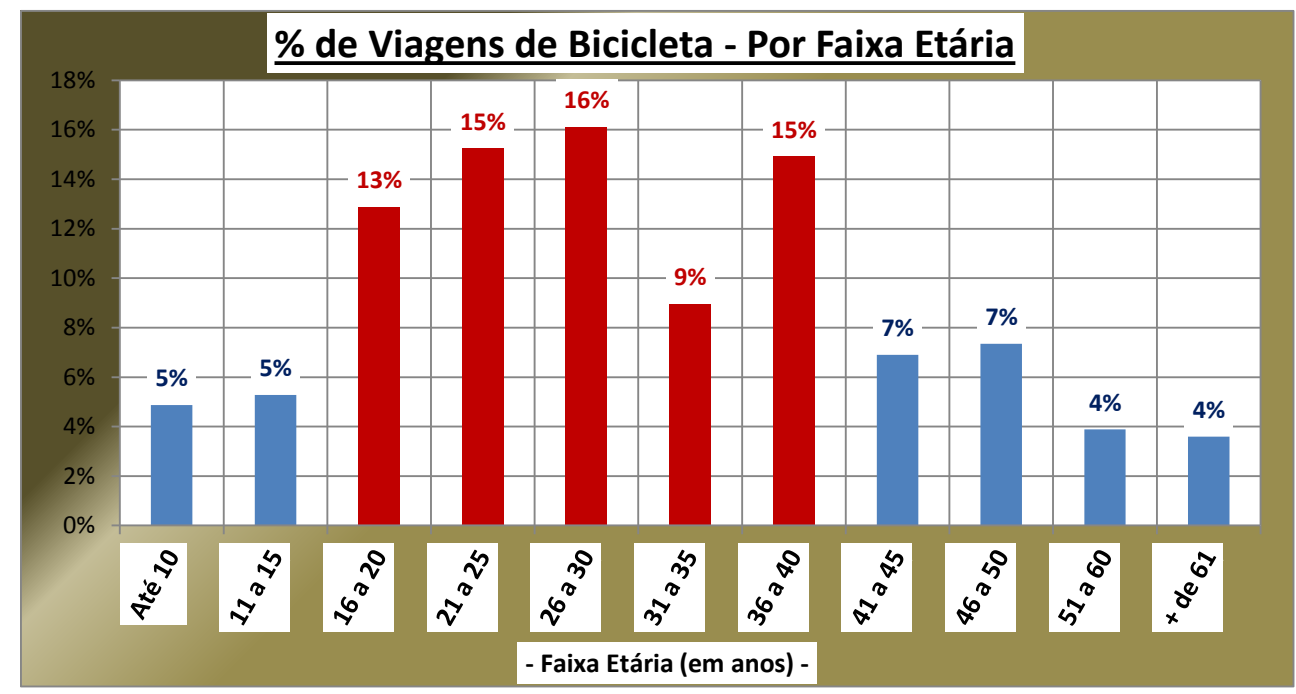

Gráfico 17 - Faixa etária dos usuários de bicicleta no Município de São Paulo Fonte: Pesquisa de Origem e Destino do Metrô - 2007 / CET/ GPL/DPJ - 2013

A causa provável pode ser atribuída a situações de maior afirmação econômica da população que thes permite buscar outra forma de deslocamento. A partir dos 36 anos uma motivação vinculada a aspectos de saúde e recomendação médica de atividade física. A partir dos 40 anos é constatada uma queda que se acentua após os 50 anos, onde as limitações das condições físicas desencorajam o uso da bicicleta.

\subsubsection{Faixa de renda do usuário da bicicleta:}

A faixa de renda salarial mensal dos usuários, exibida pelo Gráfico 18 , concentra a maioria no seguimento de um a três salários mínimos, justificando o segundo motivo alegado para uso da bicicleta que é de ordem econômica (Gráfico 15).

Esta característica possibilitava rotular à bicicleta a denominação de "transporte de pobre" pois é realmente uma forma de transporte buscada para 
contornar custos, já que a bicicleta é um veículo que não exige capital elevado para aquisição e o custo de manutenção é baixíssimo. Da mesma forma não exige investimento no processo da habilitação e não paga taxas ou licenciamento. Caso contornados os investimentos exigidos da população de baixa renda para o uso do transporte motorizado individual, certamente boa parte desta população migraria para ele.

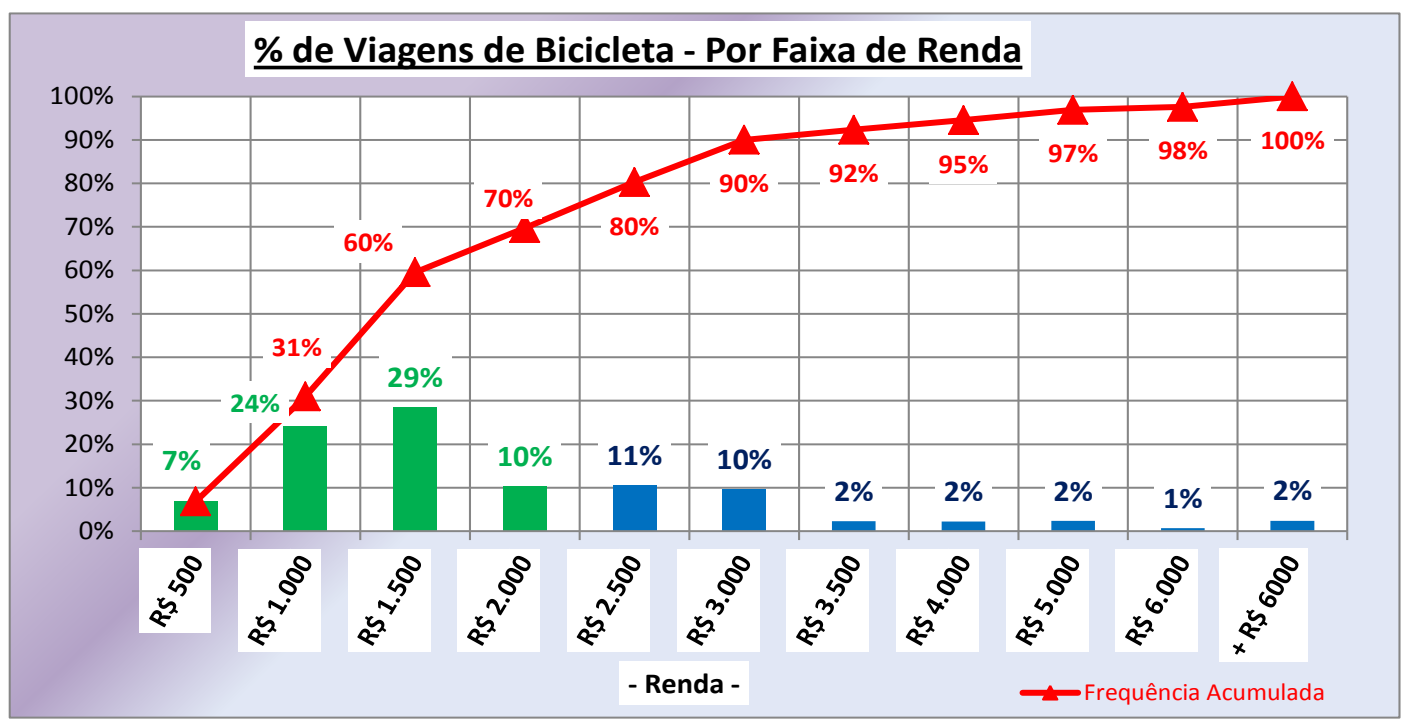

Gráfico 18 - Faixa de renda mensal dos usuários de bicicleta no Município de São Paulo Fonte: Pesquisa de Origem e Destino do Metrô - 2007 / CET/ GPL / DPJ - 2009

Um aspecto apontado também por este gráfico e que merece atenção é um pequeno acréscimo do porcentual de uso da bicicleta na faixa de renda acima dos dez salários mínimos (na ocasião da pesquisa $+\mathrm{R} \$ 6$ mil). Certamente a concentração de todos os níveis de renda acima desta faixa numa só contribui para esta subida, mas vale a pena registrar que se situa nesta faixa de renda os jovens (de faixa etária, personalidade e formação cultural) usuários de bicicleta, pertencentes às classes sociais estimulados pela possibilidade de se livrarem dos congestionamentos de trânsito, além de abraçarem a praticidade, a modernidade e praticarem $o$ bem aceito pensamento ambientalista representados pelo uso da bicicleta.

Apesar disso, cabe ressaltar que a justificativa da consciência ambientalista não consta do registro dos motivos mais alegados para o uso da bicicleta (Gráfico 15), o que caracteriza o grau da importância desta justificativa na opção por este tipo de viagem. 


\subsection{A vulnerabilidade do ciclista e sua representatividade nos acidentes de trânsito}

Como todo modo não motorizado, a vulnerabilidade do usuário da bicicleta frente aos acidentes de trânsito é uma das suas características mais marcantes. Isto pode ser constatado pela proporção inversa entre a representatividade da viagem de bicicleta na matriz dos modos de transporte paulistanos e a presença dos acidentes com bicicletas no total dos índices de acidentalidade do município: enquanto a viagem por bicicleta representa $0,6 \%$ do total de viagens diárias na matriz modal da cidade em 2007, os acidentes com vítima envolvendo ciclistas correspondem 2,7\% do total ocorrido em 2011, ou seja, um índice quatro vezes maior, conforme pode ser constatado no Gráfico 19 . Cabe ressaltar que os acidentes fatais com bicicletas em 2007 eram bem mais numerosos em relação à 2011 (respectivamente 83 em 2007 e 49 em 2011).

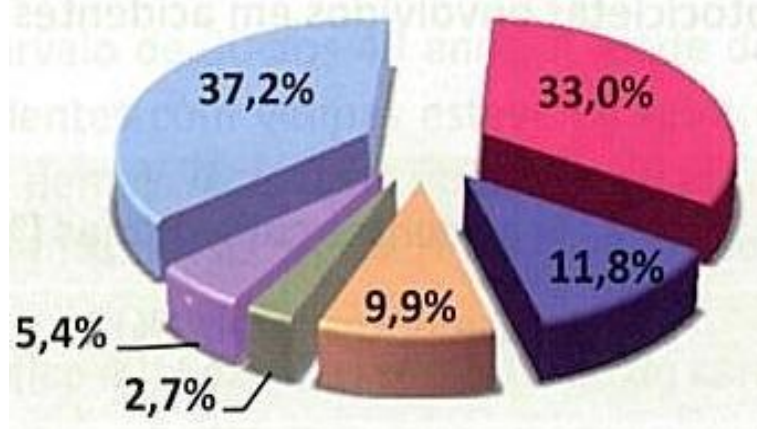

Total: 1901
Automóvel: $\quad 708$

Motocicleta: 627

回 Ônibus: 225

Caminhão: 187

回 Bicicleta: 52

国 Outros e S/I: $\quad 102$

Gráfico 19: Distribuição dos acidentes fatais por tipo de usuário da via Fonte: CET / GST - $2012^{26}$

Este aspecto evidencia a pesada desigualdade na disputa do espaço viário entre bicicleta e os modos motorizados, delineando um ambiente extremamente hostil para o ciclista. Colabora também para este cenário a falha no processo de formação do motorista que não é preparado para conviver com os usuários vulneráveis do sistema viário, sejam eles ciclistas ou pedestres.

${ }^{26}$ Fatos e Estatísticas de Trânsito em São Paulo - 2012 
Entretanto tem sido observado que o número de acidentes fatais envolvendo ciclistas vem diminuindo ao longo do tempo, inversamente à tendência do que vem ocorrendo com o número de viagens de bicicleta. Esta redução chega a quase pela metade entre 2005 (93 mortos ou 0,64 mortes a cada mil viagens) e 2010 (49 mortes ou 0,31 mortes a cada mil viagens), ${ }^{27}$ resultado este que se repete em 2011 . O Gráfico 20 apresenta a sequência histórica do número de mortes a partir de 2005.

Neste período ficam evidenciadas duas ocorrências simultâneas que certamente podem ter contribuído para a redução e a manutenção do número de fatalidades envolvendo bicicletas: uma delas é o próprio aumento do número de viagens de bicicleta, o que faz aumentar a visibilidade do ciclista no trânsito geral da cidade; e a outra, o início de políticas públicas municipais voltadas para a divulgação da bicicleta como veículo e sua utilização na via, mesmo com o apelo de lazer, como a Ciclofaixa Operacional de Lazer (conforme será detalhado adiante no item 5.5) . Apesar de tímidas, parecem ter definitivamente dado sua contribuição para a melhor a segurança do usuário ciclista.

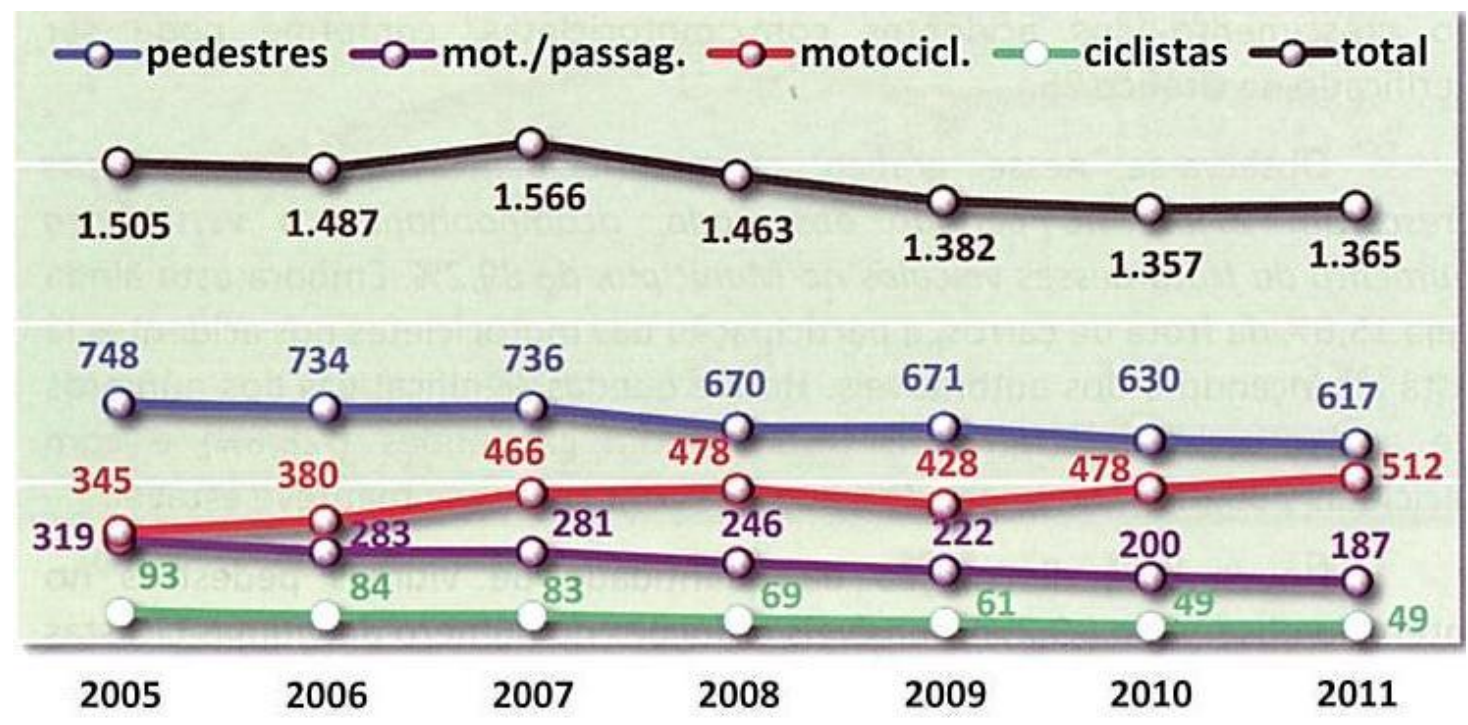

Gráfico 20 - Sequência histórica do número de mortes em acidentes por tipo de veículo Fonte: CET / GST - $2012^{28}$ entre 2005 e 2011 no Município de São Paulo

\footnotetext{
${ }^{27}$ Obs: Tomando como base para ambos os períodos o número de viagens de bicicleta no Município de São Paulo aferido pela Pesquisa de Origem e Destino de 2007 que totalizou 156.482 viagens/dia.

${ }^{28}$ Fatos e Estatísticas de Trânsito em São Paulo - 2012
} 


\subsubsection{Veículos envolvidos nos acidentes com ciclistas:}

A fragilidade característica da bicicleta, as dificuldades de compartilhamento do espaço viário aliadas à pouca existência de infraestrutura cicloviária no município de São Paulo intensifica a característica de vulnerabilidade da bicicleta, facilitando o seu envolvimento em acidentes fatais na batalha diária no disputadíssimo espaço viário da cidade.

Analisando o Gráfico 21 nota-se que o maior número de colisões envolvendo bicicletas ocorreu com automóveis (4,1\%) seguidos pelos ônibus $(3,1 \%)$, caminhões $(0,8 \%)$, motos $(0,5 \%)$ e entre bicicletas $(0,3 \%)$. Ao compararmos a proporcionalidade de participação dos vários tipos de veículos que compõem a frota paulistana com a ocorrência destes acidentes, observa-se um potencial significativo de periculosidade em relação ao ônibus na ocorrência de colisões com bicicleta (3,1\%). Em que pese a participação do ônibus na frota veicular paulistana ser bem inferior à do automóvel (responsável por $4,1 \%$ dos acidentes) esta constatação aponta a necessidade de uma atenção redobrada no processo de formação de seus condutores quanto à observação e uma postura defensiva em relação à presença da bicicleta na via como veículo .

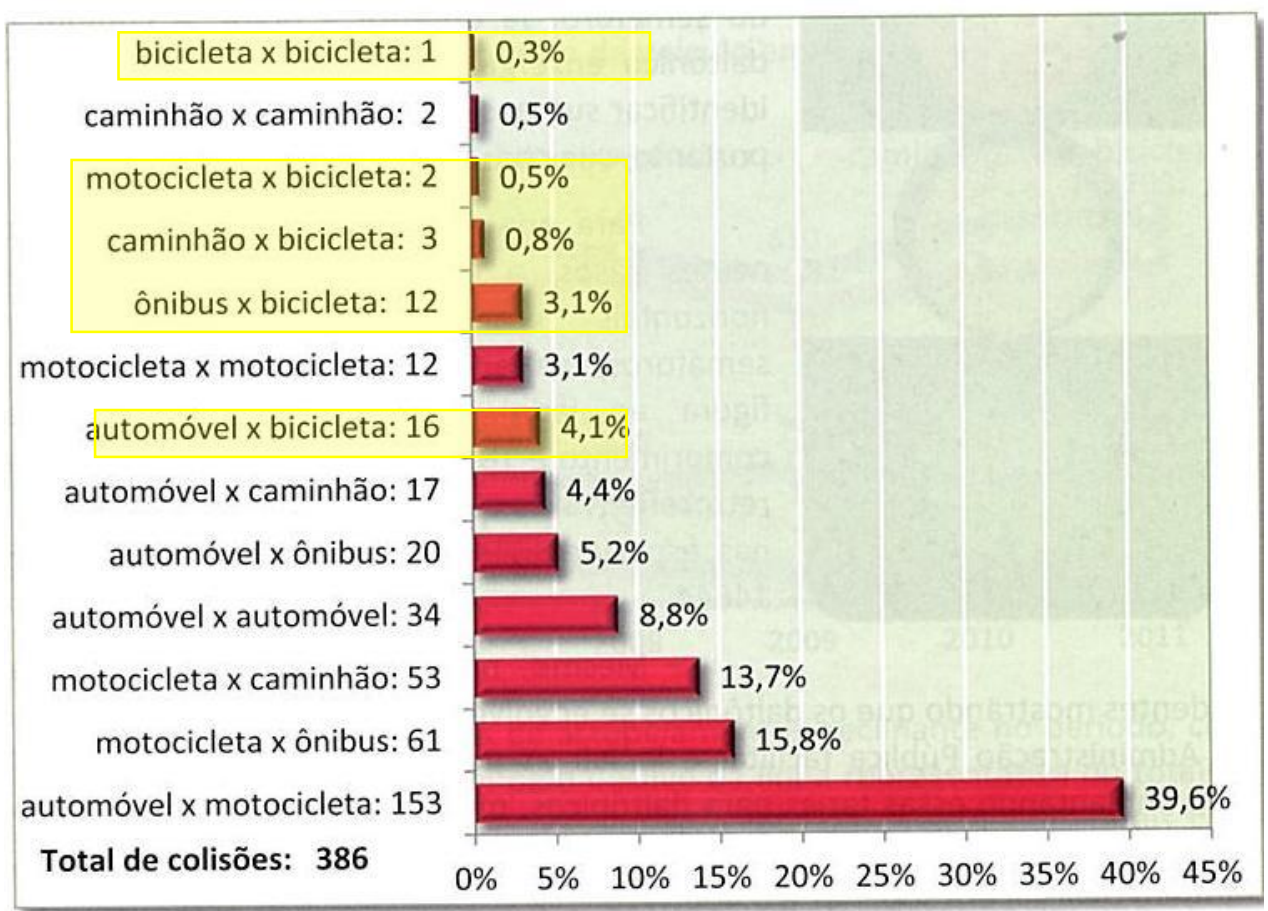

Gráfico 21 - Veículos envolvidos em colisões: 2 veículos/acidente - 2011 Fonte: CET / GST - 2012 ${ }^{29}$

\footnotetext{
${ }^{29}$ Fatos e Estatísticas de Trânsito em São Paulo - 2012
} 


\subsubsection{Faixa etária dos ciclistas vítimas de acidentes fatais:}

A faixa etária das vítimas de acidentes fatais de trânsito com bicicletas coincide, parcialmente, com a faixa etária de seu usuário, conforme exibido no Gráfico 17. Isto pode ser constatado pelo Gráfico 22, cabendo, entretanto, destacar o notável crescimento dos acidentes a partir dos 10 anos de idade, faixa etária esta onde não é muito significativo o uso diário da bicicleta de acordo com os dados mostrados pelo Gráfico 17 . Portanto este fenômeno aponta a maior vulnerabilidade presente nesta faixa etária de usuário sem contar com algum procedimento especial previsto em lei.

Outro segmento etário que se destaca é o situado entre os 30 e os 59 anos, podendo ter como justificativa a queda de desempenho e vigor físicos, naturais do aumento da idade. O fato de haver um crescimento do número de mortes no segmento ainda produtivo economicamente aponta mais uma consequência indesejável do processo pela busca de maior rapidez e flexibilidade da mobilidade cotidiana através da bicicleta, mesmo que isto signifique maior risco de vida.

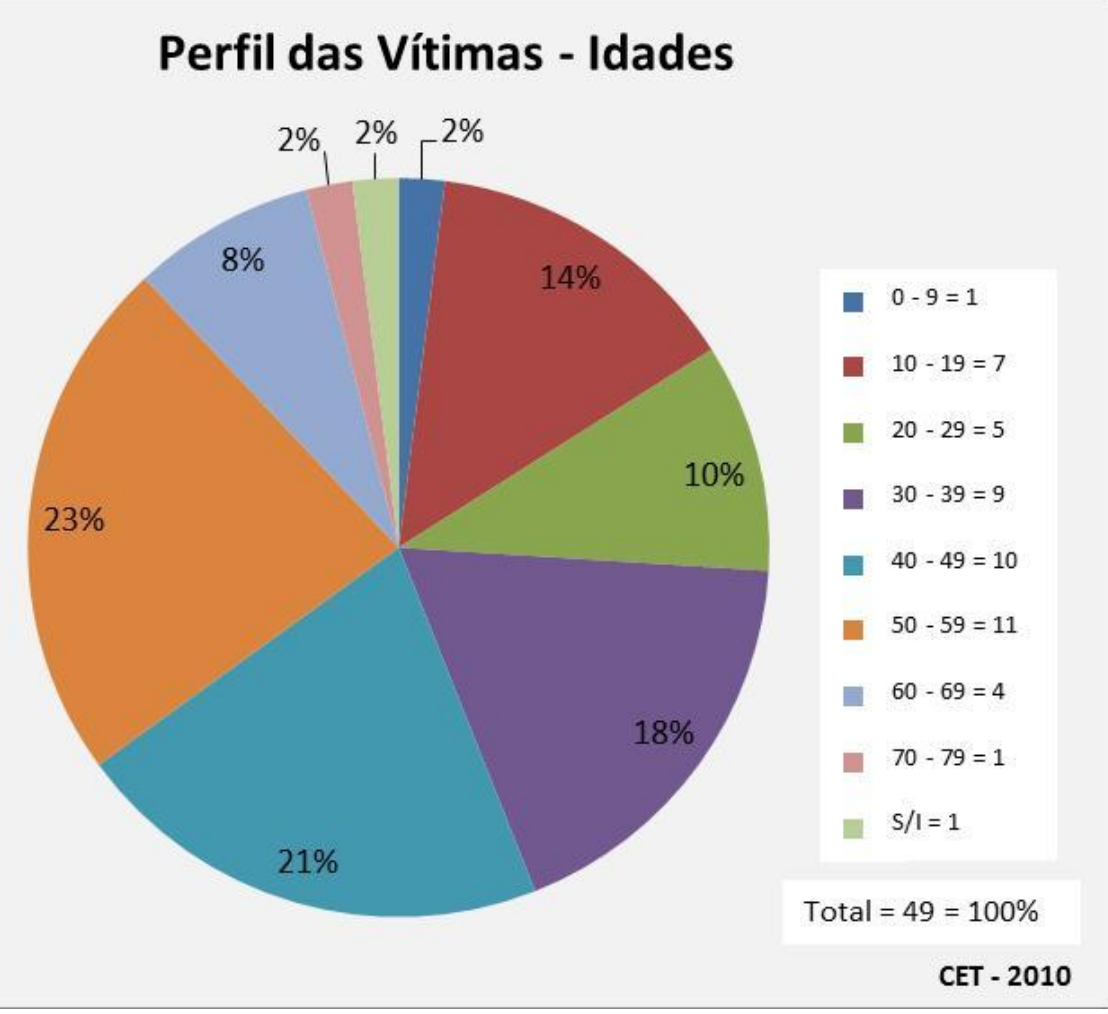

Gráfico 22- Faixa Etária das vítimas de acidentes fatais de bicicleta Fonte: CET / GST / Banco de dados de Acidentes 2010 


\subsubsection{Gênero das vítimas de acidentes fatais:}

A maioria das vítimas dos acidentes fatais de bicicleta acompanha o gênero predominante dos usuários de bicicleta (Gráfico 16) do sexo masculino, como pode ser visto no Gráfico 23. A própria natureza do transporte por bicicleta que soma o esforço físico à situação de risco justifica esta predominância, muito embora seja prevista a possibilidade de aumento no número de vítimas do sexo feminino decorrente do aumento do uso de bicicleta por mulheres que tem sido observado ultimamente em várias regiões da cidade.

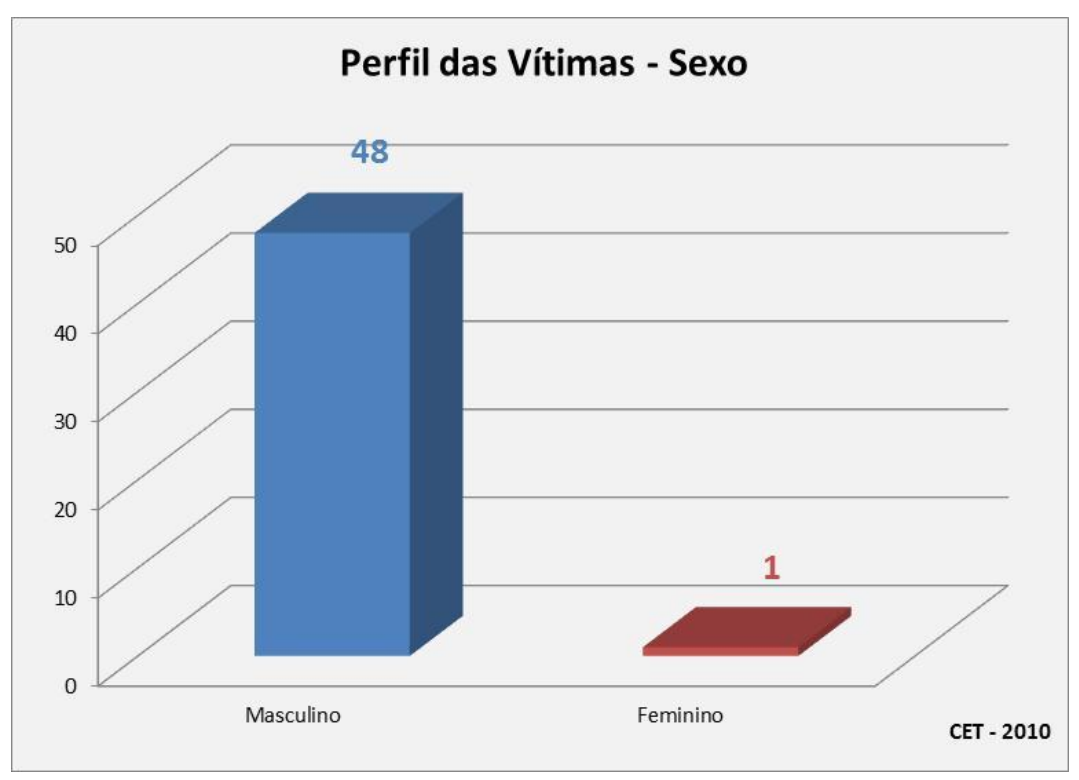

Gráfico 23- Gênero das vítimas fatais de acidentes com bicicleta - 2010 Fonte: CET / GST / Banco de dados de Acidentes - 2010

A apresentação e análise da acidentalidade da viagem de bicicleta no município de São Paulo permite constatar o preço pago pelo segmento da população que utiliza a bicicleta cotidianamente na tentativa de melhorar sua condição de mobilidade no processo de fuga do transporte público ou dos intermináveis congestionamentos de trânsito. Ao mesmo tempo expõe a urgente necessidade de preparar a malha viária e todos os usuários que dela fazem parte para absorverem e conviverem harmoniosamente com a crescente presença da bicicleta na mobilidade cotidiana de São Paulo. 
CAPÍTULO 4

LEGISLAÇÃO CICLOVIÁRIA, PROGRAMAS CICLOVIÁRIOS MUNICIPAIS E A PARTICIPAÇÃO DA SOCIEDADE 


\section{LEGISLAÇÃo CICLOVIÁRIA, PROGRAMAS CICLOVIÁRIOS MUNICIPAIS E A PARTICIPAÇÃO DA SOCIEDADE}

Este capítulo apresenta e analisa a legislação existente e as políticas públicas municipais além das formas de participação da sociedade. Destaca dificuldades da viabilização dessas políticas por serem baseadas em instrumentos legais e institucionais muitas vezes conflitantes e contraditórios quanto a sua realização e sistematização. Também detalha o processo histórico dos planos e programas da prefeitura relativos à mobilidade cicloviária e seu convívio com pressões políticas e sociais de origens diversas, nem sempre representando a legitimidade e o interesse da maioria dos usuários cotidianos da bicicleta.

A partir dos aspectos abordados torna-se possível afirmar que embora a idéia do uso da bicicleta como meio de transporte venha comparecendo nos planos e programas de governo da cidade de São Paulo há mais de 30 anos, somente a partir da última década é que uma política voltada ao setor vem sendo, efetivamente, colocada em prática.

Outro fator que pesa a esta expectativa é representado pelo ideário ambientalista, que deflagra pressão política de setores cicloativistas formadores de opinião e defensores do uso diário da bicicleta, mas voltados aos seus próprios interesses, direcionando investimentos públicos em infraestrutura cicloviária em áreas da cidade nem sempre as mais representativas e carentes de infraestrutura ciclística.

O resultado é o comprometimento da imparcialidade das ações que efetivamente fariam deste veículo uma real alternativa para certos tipos de viagens. A falta de objetividade e o desencontro de diretrizes derivadas de legislações, implantação de infraestrutura e utilização recursos, colaboram por comprometer ações políticas e físicas, direcionado recursos para intervenções muitas vezes equivocadas destinando-as ao desuso e má administração. Exemplos são as ciclovias implantadas junto às vias férreas da Radial Leste e ao longo do Rio Pinheiros, ambas segregadas dos locais de geração de viagens cotidianas, só registram maiores índices de ocupação aos finais de semana. 
Entretanto, apesar de todos estes problemas e contradições, torna-se cada vez mais concreta a presença da bicicleta como pauta constante de políticas públicas de vários municípios brasileiros, dentre eles o paulistano como repertório de transporte cotidiano. 


\subsection{LEGISLAÇÃO}

\subsubsection{Uma visão geral da legislação}

No aparato legal necessário à viabilidade das políticas de institucionalização da bicicleta como veículo para uso cotidiano no município de São Paulo ocorre, há muito, uma dicotomia. Ela é gerada, sobretudo, pelos entraves existentes para sua prática, destacando-se discrepâncias verificadas pela prática de seus mecanismos de aplicação em relação às demais legislações de trânsito e transporte.

A primeira delas refere-se à dificuldade no atendimento a atual legislação nacional de trânsito, o Código de Trânsito Brasileiro, que define comportamentos e penalidades relativos à circulação ciclística no meio viário urbano sem, no entanto, estabelecer procedimentos efetivos para colocá-los em prática. Este cenário se reflete tanto na situação de risco do convívio da bicicleta com o tráfego motorizado de forma geral, como a dificuldade de padronização das ações necessárias à regulação do uso da bicicleta enquanto modo de transporte em âmbito nacional. Isto ocorre devido à adoção de posturas individualizadas nas diversas cidades brasileiras, geradas pelas necessidades de suas realidades urbanas.

Assim desde o final dos anos 90, mais especificamente em 1997, quando passou a vigorar o Código de Trânsito Brasileiro - CTB, como veículo, o condutor da bicicleta foi incluído nas regras de condução veicular, sujeito a direitos e deveres com formatos legais que reproduziram os mesmos moldes adotados para os veículos motorizados. Entretanto, por ser um modo de transporte não motorizado, sua lógica e princípios de circulação exigiriam outra forma de abordagem e, portanto, de regulação. Isto se aplica a várias situações previstas pelo CTB como, por exemplo, à omissão da especificação da idade mínima para circulação na pista ou na calçada, obrigatoriedade ou não de treinamento/habilitação para a circulação na malha viária sem apoio de infraestrutura cicloviária, a inexistência de informações quanto a viabilização a penalização de motoristas que não respeitarem os artigos previstos para a proteção do ciclista, como o Art. 201, que exige a preservação da distância de 
1,50m do ciclista durante a ultrapassagem. Outro aspecto dúbio no Código é o que define o bordo da pista como lugar para a bicicleta circular na via, quando não há infraestrutura própria (Art. 58) como ciclovia ou ciclofaixa, sem especificar, no entanto, o que se entende como tal, se a área junto à sarjeta ou o eixo da faixa de trânsito á direita.

É importante destacar a importância do Código de Trânsito Brasileiro na definição da atribuição da política cicloviária no corpo administrativo municipal da prefeitura de São Paulo, sob responsabilidade do órgão de trânsito municipal, no caso a SMT - Secretaria Municipal de Transportes na figura do seu órgão de trânsito, a Companhia de Engenharia de Tráfego.

No que tange ao âmbito estadual a legislação é restrita e pouco significativa como deflagradora de políticas públicas. Também peca por deixar de instituir diretrizes para formatar uma rede cicloviária metropolitana integrada aos sistemas de transporte sob trilhos.

A legislação municipal que deveria apoiar e estimular o uso diário da bicicleta e mitigar as dificuldades decorrentes da sua inserção segura e responsável na divisão do uso do espaço e do tempo da cidade, foi durante muito tempo tomada por leis e decretos municipais, na maioria das vezes vazios, equivocados e oportunistas, ao mesclarem intenções de uso para esporte e lazer com as reais necessidades de uso cotidiano. Em comum expôs na maioria dos casos, uma total despreocupação em garantia de cumprimento.

Mais recentemente, quando o apelo ambiental e o discurso da sustentabilidade somados à gradativa piora do cenário da mobilidade paulistana ganharam força política, os administradores e urbanistas sensibilizaram-se para o potencial do uso da bicicleta como veículo para viagens utilitárias. Neste caldo político, o poder público paulistano tentou recuperar o tempo perdido e recorrer não só aos mecanismos legais em todas as esferas governamentais, como tentar instituir, através de outros instrumentos políticos, a tardia estruturação da cidade para o transporte por bicicleta. Os resultados de muitas destas ações de cunho imediatista e, como de praxe, sem qualquer tipo de planejamento, se sobrepuseram e se contradisseram resultando, na maioria das vezes, em legislações e programas de governo conflitantes e desarticulados, de difícil aplicação e continuidade. Poderiam até ser válidos como tentativas para 
reverter a inércia das políticas e ações públicas que sufocaram gradativamente a cidade pelas inúteis intervenções voltadas somente à priorizar a fluidez do trânsito, mas de forma nenhuma serviriam de alternativa para transporte público, seja ele sobre trilhos ou pneus.

Entretanto espera-se pela consolidação da lei municipal que estabelece o SICLO e sua aplicabilidade através de decreto regulamentador, que haja uma extrapolação dos atuais mecanismos no corpo da máquina administrativa municipal constituídos pelas exigências contidas pelos licenciamentos ambientais, e atinja as regiões da cidade onde a bicicleta já é, efetivamente, um veículo utilizado no dia a dia. Somente a partir daí poderá e deverá ser explorada a potencialidade do Transporte Cicloviário como modalidade de deslocamento em outras regiões da cidade dentro de suas características.

Finalmente deve ser destacado que toda a legislação aqui mencionada encontrase no ANEXO I ao final deste trabalho.

\subsubsection{Lei Federal 9.503/97: CTB - Código de Trânsito Brasileiro}

Sem dúvida nenhuma, o atual Código de Trânsito Brasileiro representou uma evolução na forma como a bicicleta deve ser vista e entendida, pois ao consolidar seu papel de veículo e, portanto e modo de transporte, amplia e extrapola em muito a sua condição anterior de instrumento para prática esportiva e de lazer.

Assim a evolução trazida por esta revisão na legislação foi o primeiro passo para o estabelecimento de qualquer política cicloviária de transporte em âmbito nacional, (Art. 96, Anexo I e II) com suas regras específicas de utilização da via. Ficaram também estabelecidos na lei os direitos e deveres para os ciclistas e sua posição na hierarquia das prioridades de circulação em relação ao tráfego motorizado. Deu posição à situação de condutor de veículo não motorizado, com outra lógica de circulação, não adequadamente solucionada como será justificado adiante, e também garantiu o respeito em relação ao usuário mais frágil da via, o pedestre.

Entretanto, apesar de toda esta evolução, a atual legislação de trânsito, na forma como foi concebida, apresenta ainda problemas em relação à sua aplicabilidade ao deixar algumas ações sob a responsabilidade do poder- 
municipal, tanto em relação à decisão como sua execução. São os casos da obrigatoriedade do licenciamento para conduzir bicicleta, seu emplacamento e fiscalização. Estas ações poderiam ter recebido soluções baseadas nos procedimentos bem sucedidos dos países onde a bicicleta já faz parte da frota circulante há mais tempo ou ficar sob responsabilidade do órgão de trânsito estadual que já tem a competência.

Há ainda outros pontos importantes a serem questionados na omissão, por exemplo, da faixa etária de permissão para uso urbano da bicicleta, ou deixar o órgão de cada município o cumprimento de ações importantes como a necessidade de preparação e a autorização para a condução da bicicleta na via (Art. 141).

Certamente esta indefinição contribui para que os programas públicos que envolvam alguma ação de controle do tráfego urbano ciclístico sejam de difícil aplicabilidade, induzindo os condutores de veículos, e neles o próprio condutor da bicicleta, a continuarem ignorando a bicicleta como veículo e o ciclista no papel de mais um usuário de sistema viário, sujeito a deveres e beneficiário de direitos.

Até mesmo ciclistas mais conscientes e informados justificam postura de não atendimento à legislação de trânsito como atitude de direção defensiva em função de sua condição de vulnerabilidade no uso da via e o desconhecimento, pelos motoristas, do direito que o ciclista tem de trafegar na via. Por não concordarem com as atitudes que thes são impostas pela legislação, como obediência ao sentido de circulação da via (Art. 58), proibição de trafegar na calçada (Arts. 59 e 68), obediência ao semáforo, alegam necessidades de percepção e apropriação da via específicas e diferenciadas em relação aos condutores dos veículos motorizados. Ao mesmo tempo exigem garantia de direito de uso do espaço viário possibilitada pelo maior rigor na fiscalização dos motoristas em relação ao cumprimento de artigos do CTB que thes garante integridade (Arts. 38 que estabelece prioridade ao ciclista que prossegue em frente e 201 que exige manutenção de 1,50 m de distância do ciclista nas ultrapassagens).

Portanto, assim como ocorre com o Transporte Não Motorizado a Pé, a legislação nacional de trânsito relativa ao Transporte Não Motorizado por Bicicleta, 
necessita de uma urgente revisão para solucionar contradições e dificuldades existentes, para aperfeiçoar e aferir à bicicleta e ao seu condutor, seus reais papéis enquanto componentes da matriz de mobilidade cotidiana da cidade . Para tanto vale a pena buscar soluções baseadas nas experiências consolidadas de outras realidades urbanas onde a bicicleta já se consagrou como modalidade de deslocamento urbano cotidiano.

\subsubsection{Lei Federal 12.587/12 -Lei Nacional da Mobilidade Urbana}

Esta recente legislação reforça o conceito de Transporte Não Motorizado como modalidade e confirma o estabelecido pelo Código de Trânsito Brasileiro quanto à instituição da bicicleta como veículo.

Ao obrigar e priorizar o estímulo a políticas urbanas voltadas aos modos não motorizados nas cidades através da exigência de garantia de verba para a realização de programas e infraestruturas a eles dedicados, busca consolidar a sua importância na matriz geral das viagens cotidianas e como tipologia de infraestrutura de apoio a mobilidade geral das cidades (Art. $6^{\circ}$, Art. $23^{\circ}$ ). Entretanto peca por não especificar ações e diretrizes provenientes do cumprimento do Art. $6^{\circ}$ que direcionem objetivamente a efetivação da presença de redes de Transporte Não Motorizado e sua verdadeira função na mobilidade urbana das cidades brasileiras.

\subsubsection{Legislação Estadual}

A legislação estadual que trata do assunto de infraestrutura cicloviária limita-se à poucas leis como a Lei $n^{\circ} n^{\circ} 10.095$ de 26/11/1998, que tem por objetivo disciplinar a implementação de trânsito de veículos de propulsão humana nas estradas estaduais e nos terrenos marginais às linhas férreas, estabelecendo um Plano Cicloviário do Estado de São Paulo, coordenado pelo Poder Executivo. Para possibilitar esta implementação a lei em questão propõe a construção de ciclovias (vias para bicicletas com separação física do restante do tráfego) ou ciclofaixas (pintura na pista para demarcar circulação exclusiva para ciclos) para promover a circulação intermunicipal. Propõe também que novas rodovias, em construção ou projetadas, sejam contempladas com uma destas tipologias de infraestrutura cicloviária. Em caso da utilização das áreas lindeiras a ferrovias a 
lei estabelece que deverão ser contemplados com infraestrutura cicloviária os trechos urbanos ou conurbados e os trechos rurais somente se proporcionarem acesso a locais de interesse turístico, comercial ou industrial. Esta legislação previa prazo de 180 dias para sua regulamentação, medida esta que não ocorreu até o momento.

Da mesma forma a Lei Estadual 12.286/2006 que institui a política de incentivo ao uso da bicicleta no Estado de São Paulo aborda o incentivo à mobilidade cicloviária de forma genérica e pouco significativa como política pública: "Em 2006, o governo do estado de São Paulo publicou lei de incentivo ao transporte por bicicletas. Porém, o texto era protocolar e não criava de fato nenhuma política pública sobre o tema, apenas registrava intenções de melhoria na área"30.

Cabe registrar que a legislação estadual tem pouca influência nos programas cicloviários municipais, uma vez que ela se restringe em ações genéricas. É interessante notar que, salvo a liberação da entrada de bicicleta nas redes de transporte metropolitano sobre trilhos e a implantação de bicicletários e bicicletas compartilhadas na rede metropolitana de transporte, até o momento não existe qualquer legislação estadual que aborde efetivamente, em nível metropolitano, um programa de infraestrutura cicloviária de circulação integrado aos sistemas de transporte de massa determinando assim diretrizes para o estabelecimento de rede cicloviária metropolitana intermunicipal. Qualquer iniciativa neste sentido atualmente acaba ficando ao sabor do interesse dos governos municipais e da vontade política de integração entre eles.

\subsubsection{Legislação Municipal}

O poder legislativo municipal produziu farto material sobre circulação cicloviária, parte dele de cunho oportunista, propondo a criação de ciclofaixas, ciclovias sem embasamento que pautasse sua justificativa ou condições de viabilização. Portanto foram leis que nunca saíram do papel.

De toda a legislação produzida, merecem destaque quatro leis municipais, por terem tornado minimamente viável a circulação da bicicleta na nossa cidade.

\footnotetext{
${ }^{30}$ Revista Carta Capital - "A bicicleta como meio de transporte é possível?” - 2011/junho
} 
Uma das mais recentes, institui o Sistema Cicloviário do Município de São Paulo SICLO. Apesar de não possuir decreto municipal regulamentador ainda aprovado, tem sido cumprida através dos processos licenciamento ambiental decorrentes das análises de impacto ambiental. Esta documentação é exigida para a implantação de novas intervenções da cidade, não só as voltadas para o transporte motorizado individual como projetos de novas vias, alargamento de vias existentes, como também projetos de corredores de transporte coletivo sobre pneus e os de alta capacidade, além das melhorias viárias definidas pela análise e aprovação de polos geradores e operações urbanas.

\subsubsection{Lei 10.907 / 90 - Lei das Ciclovias em Novas Avenidas}

Esta lei estabelecia a obrigatoriedade da previsão e implantação de ciclovias em novas avenidas e a implantação de ciclofaixas para ciclistas aos sábados e domingos. Embora o cumprimento desta lei não tenha sido observado, ela foi importante ao estabelecer pela primeira vez o conceito da infraestrutura cicloviária como parte da estrutura viária, nascendo junto com o projeto e a construção de uma avenida. Por este motivo foi reeditada posteriormente e até regulamentada através de decreto e atualmente está incluída em um dos artigos da lei que estabelece o SICLO.

Seu cumprimento ocorreu apenas uma vez, gerando uma ciclovia que levava o nada a lugar nenhum, juntamente com a extensão da Av. Brigadeiro Faria Lima, em direção ao bairro Alto de Pinheiros.

\subsubsection{Lei Municipal 13.430 / 02 - Plano Diretor}

O atual Plano Diretor, Lei Municipal 13.430 de 13/09/2002, incluiu na sua classificação viária definida no Art. 110 , inciso II, $\S 2^{\circ}$ : vias coletoras, a categoria ciclovia. Também institui a obrigatoriedade da implantação de ciclovias nos parques lineares, além de incluir nos planos de trânsito e transporte que compõem os Planos Regionais Estratégicos para cada uma das subprefeituras, indicação de corredores destinados a receberem ciclovias. Proíbe, ainda, instalação de rotas de ciclismo nas vias caracterizadas como N1 vias expressas. 
De forma geral as diretrizes propostas pelo Plano Diretor servem de referência para o detalhamento de planos e programas cicloviários desenvolvidos pela prefeitura.

Atualmente o Plano Diretor passa por um processo de revisão que certamente promoverá alterações nas políticas e planos cicloviários dos próximos anos uma vez que em sua preparação está incluída a diretriz de incentivo ao uso da bicicleta em São Paulo.

\subsubsection{Lei 14.266 / 07 - Lei do Sistema Cicloviário de São Paulo}

Esta lei é até o momento a mais completa no que tange à instituição de um programa e uma infraestrutura cicloviária para a cidade, enfocando o aspecto utilitário da bicicleta enquanto veículo para uso cotidiano. Ela exige a instalação de bicicletários nos terminais e estações de transporte público, visando a integração modal, amarrada com as diretrizes do Plano Diretor da cidade no que tange ao atendimento dos Planos Regionais. Ela também se preocupa em resolver aspectos relativos às deficiências na formação e informação do ciclista enquanto condutor de veículo ao instituir a obrigatoriedade de programas educativos de trânsito para ciclistas. Resgata aspectos já apontados em legislações municipais anteriores quanto à previsão de infraestrutura cicloviária de circulação em novas avenidas, remodelações de avenidas existentes, além de corredores e sistemas de transportes. Vinculada ao ideário ambientalista ela prevê o uso da infraestrutura cicloviária de circulação por outras modalidades de transporte não motorizado como patins e skate que não são, até o presente momento, definidos como veículos pelo Código Brasileiro de Trânsito.

Apesar de não estar ainda complementada, no momento de conclusão deste trabalho, por decretos regulamentadores que especifiquem sua aplicabilidade e instituam mecanismos de punição ao seu não cumprimento, esta legislação tem sido atendida através de instrumentos legais de licenciamento ambiental exigidos pela Secretaria Municipal do Verde e Meio Ambiente nos processos de análise de impacto ambiental. Entretanto esta exigência de cumprimento não leva em conta características específicas de qualquer nova intervenção viária, seja ela uma nova avenida, um trecho de túnel ou uma nova ponte. Isto pode gerar a criação de trechos de infraestrutura cicloviária de circulação 
segmentados e não articulados e portanto fadados à ociosidade em caso de atendimento à risca, sem adaptações que levem em conta a demanda e as características da viagem ciclística como, por exemplo, prever uma ciclovia em obra de túnel de longa extensão.

\subsubsection{Lei $n^{\circ} 15.649,5$ de dezembro de 2012 - Vagas para Bicicletas em}

Polos Geradores e Decreto Municipal 53.942 de 28 de maio de 2013

Esta lei prevê a obrigatoriedade da destinação de vagas para veículos de pessoas com deficiência física, motocicletas e bicicletas em quantidade relacionada ao número de vagas exigidas pela LPUOS (Legislação de Parcelamento, Uso e Ocupação do Solo - Lei Municipal 11.228/92). No caso das vagas para bicicletas o número de vagas exigidos atende à seguinte proporcionalidade: Privativo até 100 vagas - 5\%; Privativo mais de 100 vagas - 5\%; Coletivo até 10 vagas - 10\%; Coletivo mais de 10 vagas $10 \%$. 0 decreto regulamenta o cumprimento da lei e não tem encontrado dificuldades de aplicação e atendimento pois tem um forte apelo mercadológico em função do valor de imagem benéfico representado pelo uso da bicicleta. 


\subsubsection{HISTÓRICO DOS PLANOS E PROJETOS CICLOVIÁRIOS DA PMSP: DESDE OS PRIMEIROS EM 1980 ATÉ OS DIAS ATUAIS}

Instituir a bicicleta como um modo de transporte na cidade de São Paulo nunca foi prioridade como política pública ao longo das gestões municipais, uma vez que bicicleta, até recentemente, não havia se firmado como presença constante e crescente nos deslocamentos cotidianos da cidade. Tendo como possíveis justificativas, como já afirmadas anteriormente, fatores culturais aliados às condições topográficas e climáticas e intensa ocupação do espaço viário pelo trânsito motorizado, iniciativas e políticas que consolidassem a presença da bicicleta na matriz modal das viagens paulistanas ao longo do tempo não vingaram. Entretanto esta situação vem sofrendo mudanças deflagradas por motivos já abordados, fazendo com que mais e mais pessoas busquem outros meios de deslocamento que atendam a eficiência e rapidez exigidas pelo cumprimento às suas atividades rotineiras. Um destes modos, a bicicleta, tem se destacado como uma das formas de se deslocar que mais tem ganhado adeptos na cidade. Além da flexibilidade e a economia do veículo em si, outros aspectos, vinculados à atual preocupação em melhorar o trânsito e preservar o meio ambiente passam a vincular na utilização da bicicleta, uma atitude moderna e cidadã, com boa dose de autonomia sem peso no bolso .

\subsubsection{Anos 80 , diretrizes do governo federal e a crise do petróleo}

Políticas de transporte vigentes no início dos anos 80 recebiam algumas diretrizes do governo federal através do GEIPOT - Empresa Brasileira de Planejamento do Transporte, vinculada ao Ministério dos Transportes, uma vez que o país vivia sob uma ditadura militar.

Nesta época, alguns países europeus já investiam massivamente no incentivo ao uso da bicicleta como veículo de transporte cotidiano em substituição ao automóvel, pelos seus aspectos econômicos, sociais e urbanos. Os governos destes países visavam diminuir a dependência de consumo de combustíveis derivados de petróleo, cujo fornecimento foi afetado pelas sucessivas altas no preço do barril decorrente da crise do petróleo, na ocasião em sua $3^{a}$ fase. 
Este fato atingiu em cheio o mundo todo e conseqüentemente o Brasil, afetando seriamente a economia do país, conforme afirma Campos (1980) ${ }^{31}$ :" para agravar ainda mais a situação, os preços médios CIF de importação de petróleo pelo Brasil, que ficaram relativamente estáveis de 1974 até o final de 1978, subiram abruptamente em cerca de US\$14,00 por barril de janeiro de 1979 até março de $1980 . "$

Como parâmetro aos primeiros projetos de ciclovias havia a experiência européia, em especial a alemã, que iniciou a implantação de ciclovias nas cidades já nos anos 20 com o objetivo de promover a separação física entre o tráfego ciclístico e o tráfego motorizado. De fato, a preocupação vem de antes, conforme se lê na nota a seguir: "No século dezenove, as pessoas começaram a exigir ciclovias porque as ruas sem pavimentação ou pavimentadas com pedras grandes eram claramente inapropriadas para andar de bicicleta. As primeiras vias especiais construídas para ciclistas não seguiram diretrizes padronizadas ou especificações do governo. Em Bremem, Hamburgo e Lüneburg estas vias eram inicialmente seções da rua que foram melhoradas para os ciclistas. Nos arredores de Hanover e Magdeburg, as ciclovias eram usadas para o ciclismo recreacional e para fazer excursões. Estas ciclovias foram construídas graças a iniciativas próprias de clubes de ciclismo ou como facilidades providenciadas pelo município. Entre 1926 e 1928, fortes demandas foram feitas para remover os ciclistas das ruas por meio da construção de ciclovias" 32 .

Nas cidades brasileiras, entretanto, os produtos gerados pela orientação do GEIPOT não conseguiram descolar do uso da bicicleta a visão de veículo para esporte e lazer. Especificamente no caso do município de São Paulo, as diretrizes para o desenvolvimento de infraestrutura cicloviária foram atendidas através do desenvolvimento do primeiro projeto piloto de ciclovia (Imagem 1): "O primeiro projeto de ciclovia elaborado pela CET data de dezembro de 1980, e teve como intuito o estabelecimento de ligação entre dois maiores pólos de interesse ciclístico de transporte e lazer que na ocasião eram o Parque do Ibirapuera e a Cidade Universitária. 0 traçado proposto tinha 7,7 Km e

\footnotetext{
${ }^{31}$ Site IPEA-IPLAN - Martins, Marco Antônio Campos, "Impasse - Brasil na Crise do Petróleo" - Brasília, agosto de 1980

${ }^{32}$ Site Transporte Ativo - Briese, Volker - “História das Ciclovias" - tradução: Denir Mendes Miranda - 2005

- consulta realizada em 19/07/2013
} 
utilizava os canteiros centrais e calçadas das avenidas que compunham este trajeto"33 $^{33}$

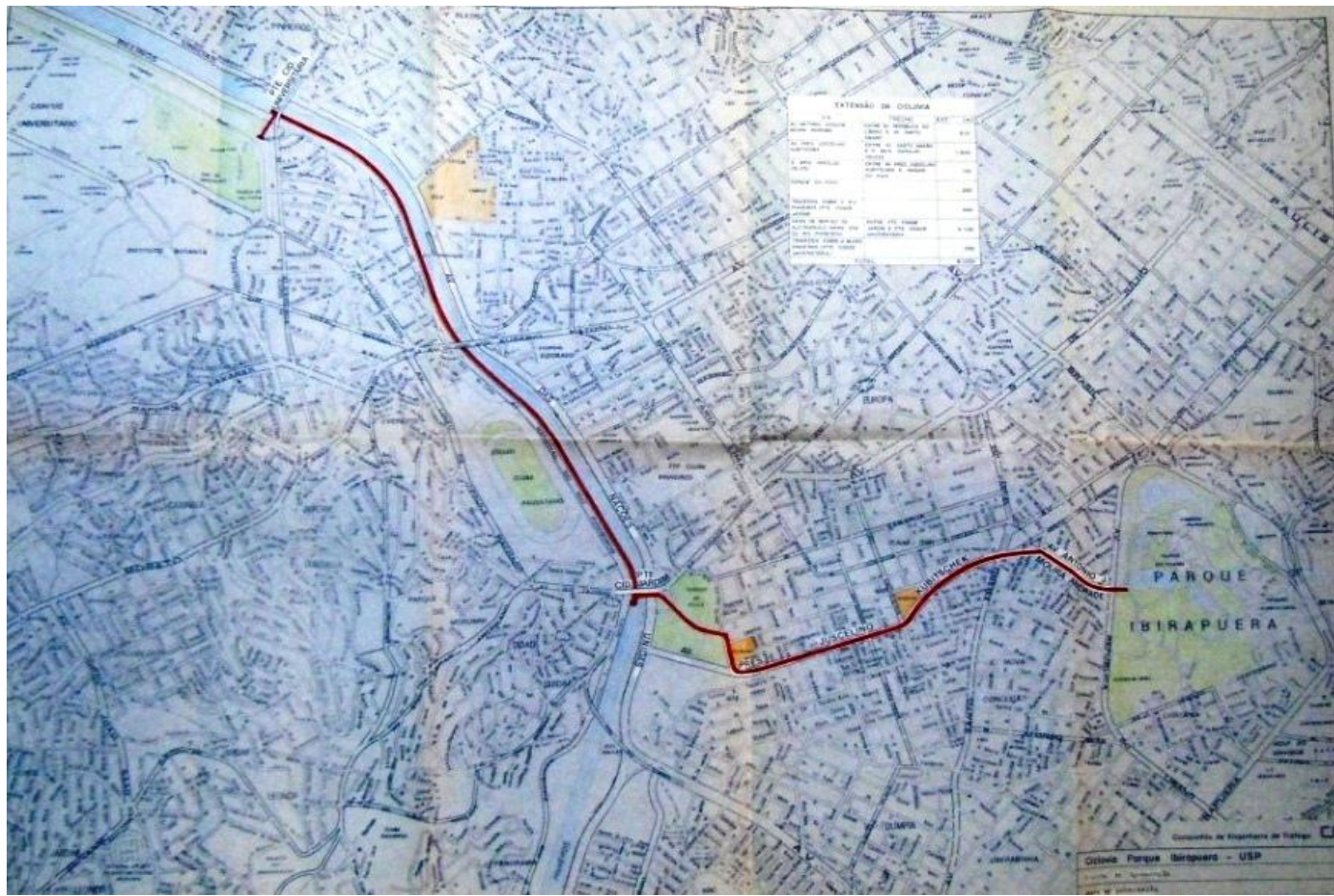

Imagem 1 - Trajeto do Estudo Piloto de Ciclovia Cidade Universitária - Parque do Ibirapuera Fonte: Boletim Técnico no 50 - CET / 2012 - apud Relatório Estudo Piloto de Ciclovia - 1980

$\mathrm{Na}$ mesma ocasião a CET desenvolveu um plano de ciclovias denominado “Sistemas Cicloviários Setoriais" ${ }^{34}$, de 1981, que procurava estabelecer uma rede cicloviária na cidade (Imagens 2 e 3).

Sem saber exatamente como se comportava e se localizava a demanda das viagens de bicicleta no município, uma vez que estas ainda não eram registradas na Pesquisa de Origem e Destino do Metrô, adotou-se como metodologia para a elaboração daquele plano, a seleção de avenidas que apresentassem em seus canteiros centrais, espaço suficiente para acomodar uma pista para circulação de bicicletas.

Havia também o requisito da articulação destes corredores entre si de forma a estruturar uma rede regionalizada, respeitando a escala da viagem de bicicleta e assim adotou-se como metodologia a divisão do município em setores. Muitas destas avenidas (exemplo: Inajar de Souza, Caetano Álvares, Sumaré, Carvalho

\footnotetext{
${ }^{33}$ Companhia de Engenharia de Tráfego SP - Boletim Técnico no 50 -“ A História dos Estudos de Bicicleta na CET"- Malatesta, Maria Ermelina Brosch - 2012

${ }^{34}$ Companhia de Engenharia de Tráfego SP - Boletim Técnico no 50 -“ A História dos Estudos de Bicicleta na CET"- Malatesta, Maria Ermelina Brosch -2012
} 


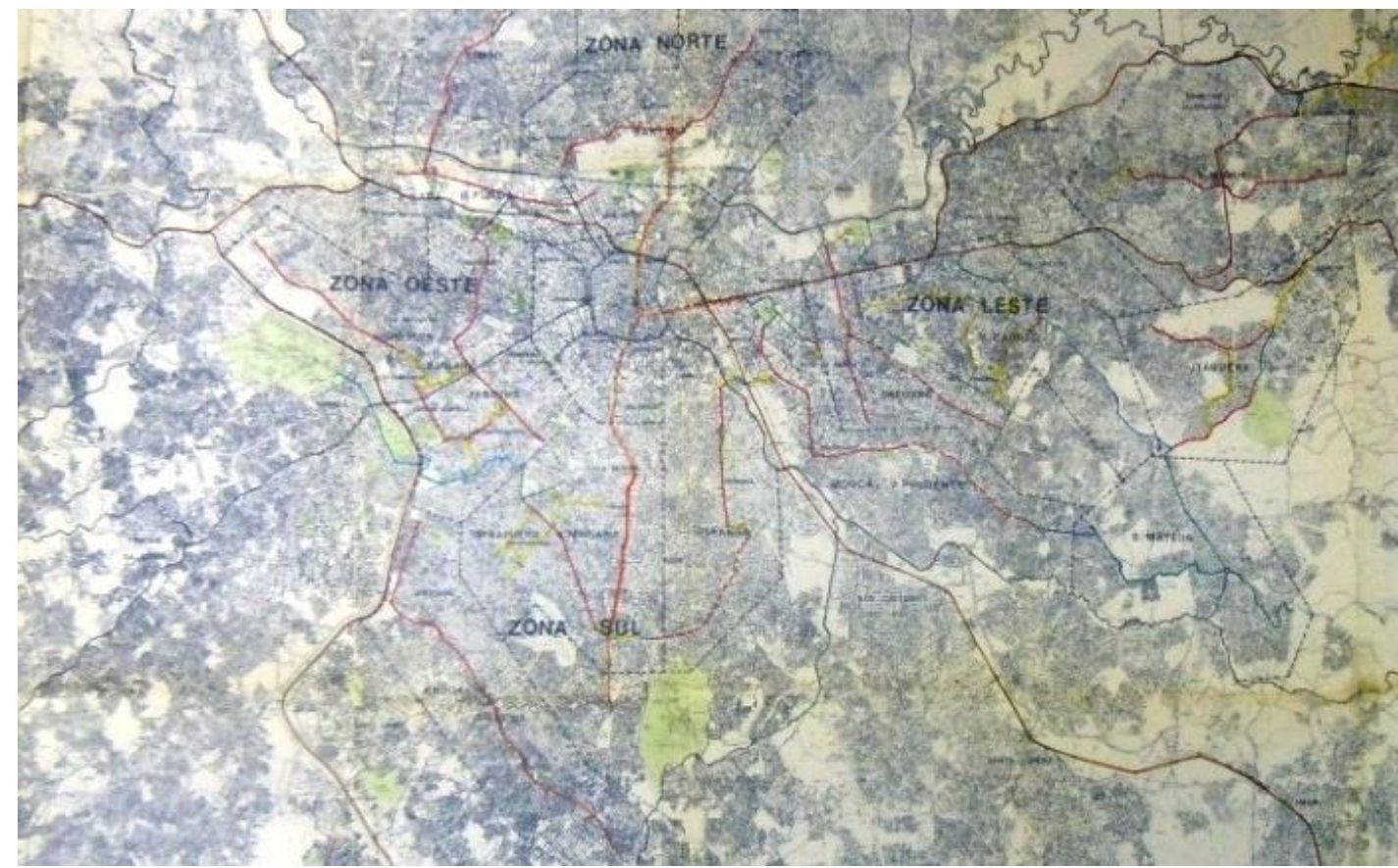

Imagem 2 - Mapa com os corredores que compunham o plano "Sistemas Cicloviários Setoriais"

Fonte: Boletim Técnico no 50 - CET / 2012 - apud Relatório Sistemas Cicloviários Setoriais - CET - 1981

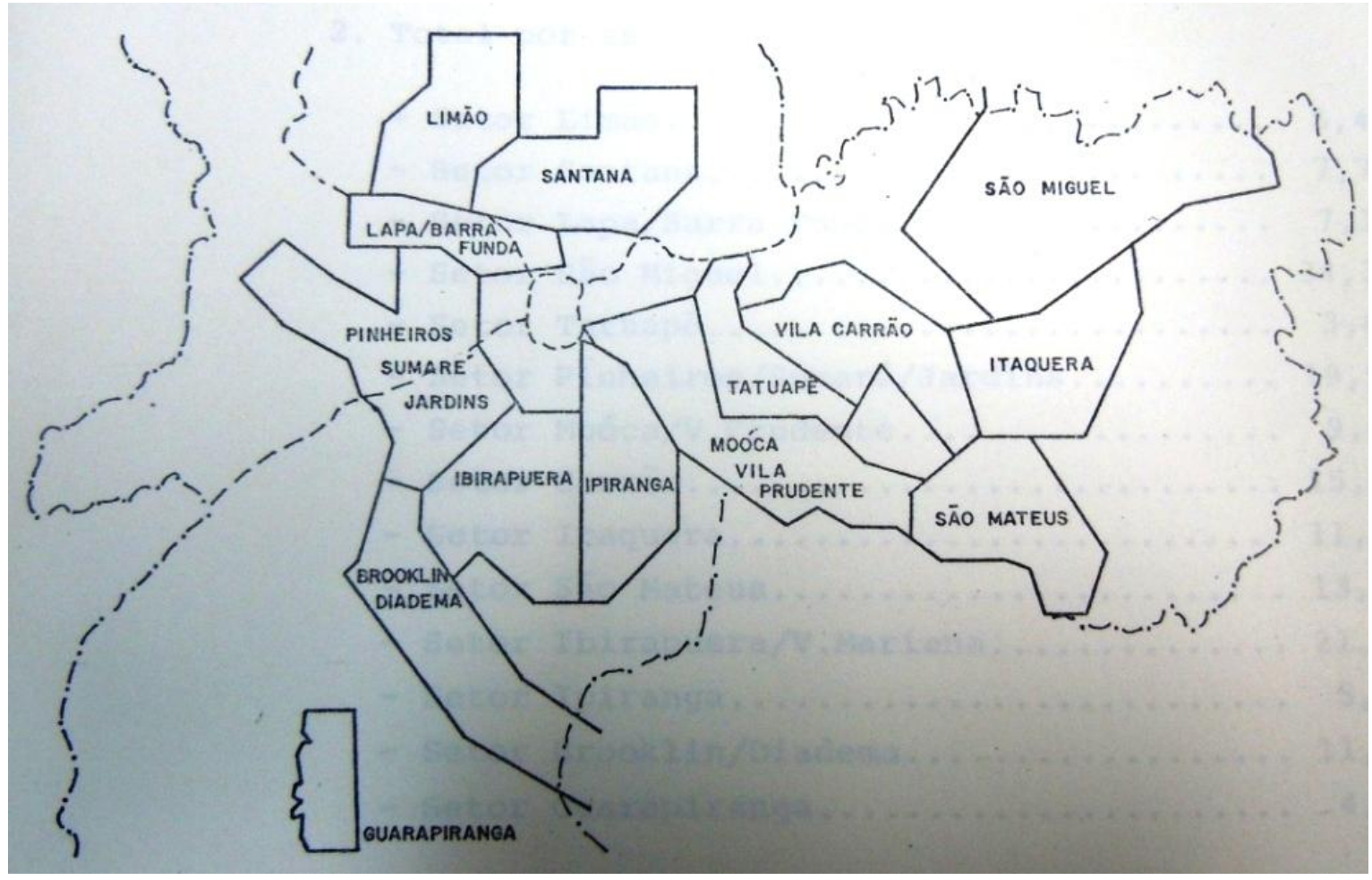

Imagem 3 - Divisão dos Setores que compunham o plano "Sistemas Cicloviários Setoriais" Fonte: Boletim Técnico no 50 - CET / 2012

Pinto) pertenciam ao programa municipal de canalização dos córregos de fundo de vale que se mostravam adequadas por serem planas com amplos canteiros. 
"A cidade foi subdividida em 14 setores definidos a partir do traçado cicloviário proposto para cada um deles e estes sistemas também foram articulados entre si, de forma a estruturar uma rede cicloviária para todo o município que "totalizava aproximadamente $174 \mathrm{~km}$ de extensão, composta por ciclovias, ciclofaixas, vias cicláveis e tráfego compartilhado na calçada. "35

O plano resultante era ambicioso para a época. Entretanto nunca saiu do papel: "A proposta contida neste plano não se efetivou, muito embora várias das intervenções previstas por ele tenham sido realizadas posteriormente, como é o caso das ciclovias previstas para as avenidas Sumaré, implantada no canteiro central da avenida em 1996, Pedroso de Morais, implantada no canteiro central do prolongamento da Av. Brig. Faria Lima em 1995, Inajar de Souza, implantada no canteiro central da avenida em 2007"36.

Portanto algumas das poucas ciclovias existentes em São Paulo já haviam sido previstas desde este plano de 1981.

\subsubsection{Anos 90: políticas ambientais e o reconhecimento da bicicleta no CTB} Já em meados dos anos 90 foi criada a Assessoria de Meio Ambiente na estrutura organizacional da prefeitura de São Paulo, que passou pouco depois para status de secretaria municipal - SVMA, Secretaria Municipal do Verde e Meio Ambiente. Um dos programas de política ambientalista desenvolvidos por esta secretaria, o Projeto Ciclista ${ }^{37}$, tinha como objetivo "estabelecer as ações necessárias à implementação de infraestrutura urbana e educativa para o conforto, segurança e economia do cidadão ciclista"38. Este programa envolvia, entre as ações, a implantação de ciclovias na cidade, principiando pelas áreas de domínio da própria secretaria, os parques municipais. Assim foram criadas ciclovias ${ }^{39} \mathrm{em}$ muitos dos parques da cidade: Parque do Ibirapuera, Parque Anhanguera, Parque do Piqueri, Parque do Carmo e CEMUCAM (Centro Municipal de Campismo).

\footnotetext{
${ }^{35}$ Companhia de Engenharia de Tráfego SP - Boletim Técnico no 50 - " A História dos Estudos de Bicicleta na CET"- Malatesta, Maria Ermelina Brosch -2012

${ }^{36}$ Companhia de Engenharia de Tráfego SP - Boletim Técnico no 50 - “ A História dos Estudos de Bicicleta na CET" -Malatesta, Maria Ermelina Brosch - 2012

${ }^{37}$ Portaria 394 de 23/12/93 - Institui o Projeto Ciclista, atribuindo à SVMA a coordenação do projeto, visando sua implementação

${ }^{38}$ Projeto Ciclista - SVMA - 1994, apud Companhia de Engenharia de Tráfego SP - Boletim Técnico no 50 Malatesta, Maria Ermelina Brosch - 2012

39 Portaria 014/SVMA-G/95 - Autoriza a entrada de bicicletas nos parques municipais administrados pelo Departamento de Parques e Áreas Verdes, observado o regulamento de cada parque.
} 
Outra ação política da prefeitura de São Paulo foi de natureza legal com a aprovação das primeiras leis municipais que instituíram: a) faixas para circulação de bicicletas em algumas vias da cidade aos finais de semana; b) a obrigatoriedade da construção de ciclovias nas novas obras viárias da cidade. Entretanto a aplicação destas duas leis, foi praticamente nula. As faixas para bicicletas aos finais de semana praticamente nunca funcionaram e a obrigatoriedade das novas avenidas terem ciclovia só foi aplicada em uma intervenção viária e de forma inadequada, resultando na implantação de uma ciclovia inútil, conforme explicado no ítem 4.1.4.1.

Houve também um novo plano cicloviário desenvolvido pela CET nesta mesma época, "Plano de Ciclovias para o Município de São Paulo" de maio $1994{ }^{40}$ com o objetivo de incentivar o uso da bicicleta como meio de transporte através da

\begin{tabular}{|c|c|c|c|}
\hline ZONA & NOME & TIPO & EXTENSÃO (Km) \\
\hline Centro & São João (elevado) & operacional & 4,00 \\
\hline Leste & Aricanduva & permanente & 15,00 \\
\hline Leste & Córrego Rio Verde & permanente & 4,00 \\
\hline Leste & Gov. Carvalho Pinto & permanente & 3,40 \\
\hline Leste & Jacu-Pêssego & permanente & 15,00 \\
\hline Leste & Marechal Tito & permanente & 10,00 \\
\hline Noroeste & Edgar Facó & perman/ operac & 5,00 \\
\hline Norte & Braz Leme & permanente & 4,00 \\
\hline Norte & Engo. Caetano Álvares & permanente & 4,00 \\
\hline Norte & Inajar de Souza & permanente & 5,00 \\
\hline Norte & João Paulo I & permanente & 2,00 \\
\hline Norte & Luis Dumont Villares & permanente & 5,00 \\
\hline Sudeste & Luis Inácio de A. Melo & permanente & 6,70 \\
\hline Sudeste & Nazaré & operacional & 2,30 \\
\hline Sul & Luis G. C. Sangirardi & permanente & 1,20 \\
\hline Sudoeste & Brig. Faria Lima & permanente & 1,20 \\
\hline Sudoeste & Ibirapuera - USP & perman/operac. & 7,20 \\
\hline Sudoeste & Jd. Luzitânia & permanente & 1,00 \\
\hline Sudoeste & Sumaré & permanente & 3,50 \\
\hline Sudoeste & $\begin{array}{c}\text { Uberabinha - Ibirapuera (Hélio } \\
\text { Pelegrino) }\end{array}$ & permanente & 5,00 \\
\hline Sul & Robert Kennedy & permanente & 6,00 \\
\hline TotalOperacional & & & 6,3 \\
\hline $\begin{array}{l}\text { TotalPermanente } \\
\text { e Perm/Operac }\end{array}$ & & & 104,2 \\
\hline Total Geral & & & 110,5 \\
\hline
\end{tabular}

Tabela 10 - Plano de Ciclovias de 1994 - QUADRO RESUMO

Fonte: Boletim Técnico no 50 - CET / $2012^{41}$

\footnotetext{
${ }^{40}$ Companhia de Engenharia de Tráfego SP - Boletim Técnico no 50 -“ A História dos Estudos de Bicicleta na CET" - Malatesta, Maria Ermelina Brosch - 2012
} 
construção de ciclovias nas avenidas que proviam acesso aos parques e áreas de lazer da cidade, e assim estender também o hábito do uso de bicicleta para o cotidiano à população que as utilizasse aos finais de semana (Tabela 10).

Este plano demonstra que, da mesma forma como ocorreu na década anterior, a ação política que pretendia consolidar o uso da bicicleta como veículo para transporte cotidiano, não conseguia despregá-la de sua característica de lazer e esporte.

Um dos motivos pode ser atribuído ao fato, tal qual ocorrera na década de 80, de não haver ainda disponibilidade de pesquisas e banco de dados que permitissem aferir, localizar e caracterizar a demanda utilitária das viagens por bicicleta em São Paulo, de forma a instrumentalizar o planejamento e a implantação da infraestrutura de atendimento a esta finalidade. Mais uma constatação de que não havia ainda vontade política para realmente planejar a inserção da bicicleta na matriz modal paulistana.

Encerrando esta década, no final dos anos 90, mais especificamente em 1997, com a nova legislação de trânsito instituída pelo CTB - Código de Trânsito Brasileiro $^{42}$, a bicicleta passa a ser definida e reconhecida como veículo não motorizado, movido à propulsão humana. O estabelecimento dos direitos e deveres do ciclista assim como aos motoristas em relação aos ciclistas, legalizaram-na definitivamente como veículo para o transporte utilitário, não somente para lazer e prática de esporte. Entretanto, neste mesmo código, não constou um aprofundamento necessário a esta nova situação, ao instituir procedimentos algumas vezes polêmicos e de difícil realização, atendimento, controle e regulação, conforme já exposto no item 4.1.4.5.

\subsubsection{Primeira década de 2000 e a efetivação da política do transporte por bicicleta no município de São Paulo}

No estabelecimento do novo Plano Diretor de 2002 e seu detalhamento nas propostas para os sistemas de transportes dos Planos Regionais Estratégicos, ficam incluídas, na maioria das 31 subprefeituras do município de São Paulo,

\footnotetext{
${ }^{41}$ Companhia de Engenharia de Tráfego SP - Boletim Técnico no 50 -“ A História dos Estudos de Bicicleta na CET" - Malatesta, Maria Ermelina Brosch - 2012

${ }^{42}$ Código de Trânsito Brasileiro - Lei Federal no9.503 de 23/09/1997
} 
indicações de vias para implantação de infraestrutura de circulação cicloviária. Cabe lembrar que estas indicações são resultado de encontros e audiências entre o poder público e a sociedade.

Nesta mesma época começam a ser implantados em alguns terminais de ônibus da cidade os primeiros locais reservados exclusivamente ao estacionamento de bicicletas, equipados de paraciclos.

Outro fato digno de nota ocorrido ao longo deste período refere-se ao fenômeno de intensificação relevante do número de viagens utilitárias realizadas por bicicleta, como nunca ocorrera anteriormente. Mesmo representando uma parcela insignificante do total das viagens realizadas no município e na região metropolitana de São Paulo, estes acréscimos atingiram índices próximos a $200 \%$ entre 1997 e 2007 de acordo com a Pesquisa de Origem e Destino do Metrô.

Este fenômeno indica que as deficiências na mobilidade urbana de São Paulo foram de tal monta que nem mesmo as políticas tarifárias unificadas praticadas a partir de 2004 tiveram capacidade de atender a maioria da populaçãoem relação à qualidade necessária aos seus deslocamentos. Assim, à parcela da população que anteriormente recorria ao uso da bicicleta tendo como motivo principal a falta de condições para pagamento da tarifa, são adicionados como usuários cotidianos os que a ela recorrem como forma de melhorar sua qualidade de vida ao tentar reduzir o tempo perdido nos deslocamentos diários.

Atenta a este fenômeno, a Pesquisa de Origem e Destino do Metrô passa a registrar, com maiores detalhes, as viagens realizadas por bicicleta partir de 1997, já tendo sido percebida uma tendência de alta das viagens ciclísticas na realização da pesquisa intermediária (em 2002). Seus resultados justificam a retomada, como política pública de transporte, das diretrizes que determinam o enfoque utilitário da bicicleta para uso cotidiano, passando afirmar-se uma das prioridades da prefeitura de São Paulo e do governo estadual a partir de 2005.

Por ser considerada um veículo verde, de nível zero de emissão de dióxido de carbono, a coordenação das ações que constituiriam a política de estímulo ao uso da bicicleta na prefeitura de São Paulo ficou sob responsabilidade da Secretaria Municipal do Verde e Meio Ambiente apoiada pela Secretaria Municipal de Transportes. 
Também no início de 2005 foi criado o Grupo de Trabalho Bicicleta, o GT Bicicleta, formado por representantes de órgãos municipais, estaduais e membros sociedade. Este grupo produziu um documento constituído de programa de intenções, juntamente com um plano de infraestrutura cicloviária de enfoque utilitário totalizando $104,8 \mathrm{~km}$ de ciclovias (Tabela 11). Foi denominado "Relatório do Grupo de Trabalho Interinstitucional para Estudar o Fomento do Uso da Bicicleta como Meio de Transporte Não Motorizado e Instrumento de Melhoria Ambiental com Indicação de Áreas para Intervenção

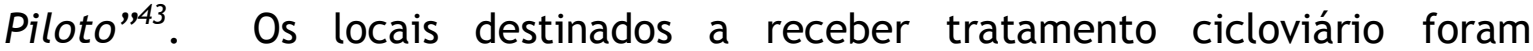
selecionados a partir do cruzamento das informações da Pesquisa Origem e Destino do Metro (atualização de 2002) e dos corredores viários indicados para receberem ciclovias constantes nos Planos Regionais Estratégicos de 2002.

$\mathrm{Na}$ sequência, o grupo formado para elaborar este estudo, foi consolidado através de portaria municipal como grupo executivo intersecretarial responsável pela coordenação das políticas cicloviárias municipais denominado Grupo ProCiclista ${ }^{44}$, cuja coordenação ficou sob responsabilidade da Secretaria Municipal do Verde e Meio Ambiente.

\begin{tabular}{|l|c|c|c|c|}
\hline \multicolumn{1}{|c|}{ Região } & Ciclovia & Ciclofaixa & Tráfego compartilhado & Total \\
\hline Norte & 17,3 & -- & -- & 17,3 \\
\hline Leste & 27,6 & 1,00 & 15,8 & 44,4 \\
\hline Oeste & 8,5 & -- & 1,40 & 9,9 \\
\hline Sul & 18,7 & 0,40 & 14,1 & 33,2 \\
\hline Total & 72,1 & 1,40 & 31,3 & 104,8 \\
\hline
\end{tabular}

Tabela 11: Total Geral de intervenções previstas no relatório do Grupo de Trabalho Interinstitucional - Julho 2005

Fonte: CET - Boletim Técnico nº 50 - 2012

Entretanto a competência técnica desta secretaria no organograma da prefeitura municipal não viabilizava as ações necessárias à implementação da infraestrutura cicloviária planejada pelas políticas municipais, tendo em vista tratar-se de sistema viário e, portanto, sob responsabilidade da SMT, Secretaria Municipal de Transportes.

\footnotetext{
${ }^{43}$ Companhia de Engenharia de Tráfego SP - Boletim Técnico no 50 -"A História dos Estudos de Bicicleta na CET" - Malatesta, Maria Ermelina Brosch - 2012

${ }^{44}$ Portaria Municipal no 1918 - 18 de maio de 2006
} 
Nesta mesma época (2005), em função das pressões exercidas pelas subprefeituras interessadas na implantação das intervenções cicloviárias constantes dos Planos Regionais Estratégicos e por grupos sociais envolvidos em promover o uso da bicicleta nos deslocamentos cotidianos, foi gerado um impasse institucional solucionado no organograma da prefeitura por uma mudança de competências. Esta mudança estabeleceu que a partir de julho de 2009, a Secretaria Municipal de Transportes passaria a responder pelo programa cicloviário do município de São Paulo assim como o Grupo Pró Ciclista ${ }^{45}$.

\subsubsection{A década atual e a coordenação do programa cicloviário pela}

\section{Secretaria Municipal de Transportes}

A primeira ação da nova coordenação foi a reformulação do plano cicloviário anteriormente elaborado pelo Grupo de Trabalho Bicicleta, para readequá-lo aos dados obtidos pela recém divulgada Pesquisa OD de 2007, e com o enfoque de contemplar exclusivamente a utilização da bicicleta como de meio de transporte por motivo trabalho.

A segunda ação, ao final de 2009, foi a criação de uma área técnica dentro da estrutura organizacional da prefeitura paulistana, na Companhia de Engenharia de Tráfego, para se dedicar ao desenvolvimento e execução das ações que incorporariam a política cicloviária municipal, responsabilizando-se pelas intervenções técnicas necessárias à implementação desta política.

A tarefa inicial desta nova área foi detalhar um plano de rede cicloviária para a cidade, totalmente focado no aspecto utilitário da viagem de bicicleta. As áreas de abrangência deste plano constam do Mapa 3, e serão abordadas no ítem 5.2 .

Outras atribuições da área: acompanhamento do desenvolvimento das redes cicloviárias das subprefeituras; projetos e planos oriundos do atendimento à legislação municipal que estabelece obrigatoriedades de infraestrutura cicloviária em novas intervenções viárias; indicação de novas demandas de sinalização cicloviária não previstas no Código de Trânsito Brasileiro e o desenvolvimento da rede cicloviária operacional de lazer, as Ciclofaixas de Lazer. Algumas destas intervenções serão abordadas e detalhadas no Capítulo 5.

\footnotetext{
${ }^{45}$ Decreto Municipal no 50.708 - 2 de julho de 2009
} 


\subsubsection{Tendências Futuras da Política Cicloviária}

Como conseqüência da consolidação de estrutura institucional para concretizar o uso da bicicleta como modo de transporte cotidiano é presumível a permanência da tendência de aumento do número de viagens de bicicleta no município de São Paulo.

Que tipo de viagens serão e onde estarão localizadas irá depender de como serão conduzidas as demais políticas de transporte do município. Em caso de continuidade da atual situação de precariedade do transporte público, certamente as características das viagens e da sua localização deverão reproduzir o quadro atual, com pesquisas de transporte apontando regiões mal servidas como prioritárias na condução da política cicloviária. Entretanto esta prioridade poderá ficar comprometida pelo provável aumento da pressão política oriunda dos movimentos cicloativistas (detalhados no item 4.3.) que certamente continuarão a puxar as ações para a região do Centro Expandido, onde majoritariamente estão situados e onde há maior visibilidade política.

Outro potencial de demanda já existente é caracterizado pela intensificação do bicifrete, ou seja, entrega de mercadorias de pequeno porte (lanches, documentos, medicamentos, serviços gráficos) em pequenas extensões de até 3 Km) tanto em corredores de serviços (avenidas Paulista, Berrini, Faria Lima) como nas vias e calçadões da Área Central, em substituição à moto nos percursos inseridos na escala da viagem de bicicleta. A necessidade de capacitação de seus profissionais certamente exigirá do poder público a criação de treinamento cicloviário específico que abranja legislação de trânsito, condução defensiva, conhecimento e manejo adequado do veículo.

O serviço de bicicletas públicas ou de aluguel, em complementação à viagem de transporte público, apesar de estar em seu início e com interesses mercadológicos inerentes, também apresenta grande potencial de uso, principalmente se integrado aos sistemas de transporte público através do Bilhete Único como deseja a atual administração municipal (assunto a ser detalhado no item 6.2 .

Finalmente cabe destacar o papel da infraestrutura cicloviária voltada ao lazer e educação ciclística desenvolvida pela prefeitura de São Paulo em parceria com a 
iniciativa privada ${ }^{46}$, as Ciclofaixas de Lazer. Onerosas por envolverem uma verdadeira megaoperação para montagem, desmontagem e operacionalização semanal, deverão ser paulatinamente consolidadas por infraestrutura cicloviária definitiva, quando a demanda pela consolidação do uso da bicicleta for tal que possa dispensar esse aparato de visibilidade estratégica e roubar espaço viário do tráfego motorizado. Estas intervenções definitivas poderiam até rever a localização das ciclofaixas de lazer laterais às calçadas das vias onde estão situadas, de forma a melhor se integrarem nas atividades cotidianas da cidade.

\footnotetext{
${ }^{46}$ Companhia de Engenharia de Tráfego SP - Boletim Técnico no 50 - " A História dos Estudos de Bicicleta na CET" - Malatesta, Maria Ermelina Brosch - 2012
} 


\subsection{Cicloativismo e cicloativistas : formadores de opinião e indutores de políticas e negócios}

Já foi mencionado anteriormente que a maioria da população que utiliza diariamente a bicicleta como modo de transporte pertence às camadas da população trabalhadora, masculina, jovem, classes de renda $C$ e $D$, que encontram na bicicleta, uma forma de fugir das más condições dos serviços oferecidos pelo transporte público. Entretanto existe uma parcela da população pertencente a classes $A$ e $B$ e que vê na bicicleta não só uma forma de escapar dos congestionamentos das viagens de automóvel, como também uma forma de engajamento e participação política, proveniente da imagem positiva que a bicicleta ocupa no ideário da modernidade, do não tradicional, do saudável e do alternativo .

O número de viagens diárias geradas por esta parcela da população não é o mais representativo do modo bicicleta ao ponto de não ter sido detectado nas pesquisas de $2007^{47}$, e confirmado pelos dados expostos no Mapa 8 , que situa vetores com menos de 50 viagens/dia nos bairros internos ao Centro Expandido, onde se concentra a maioria desta população. 0 poder de mobilização e pressão de seus representantes, entretanto, tem se mostrado extremamente eficientes na sensibilização da máquina governamental, da mídia, enfim, da opinião pública, para a questão da viabilidade do uso da bicicleta como modo de transporte para o cotidiano paulistano.

$\mathrm{Na}$ grande maioria das vezes este poder de fogo fica direcionado ao atendimento dos próprios interesses, induzindo uma reversão na hierarquização das prioridades políticas, que direcionam ações, recursos e investimentos públicos para as regiões ocupadas por setores minoritários e já privilegiados da sociedade. Assim mais uma vez corre-se o risco de relegar a um plano secundário as necessidades dos setores da população mais prejudicados pelos crônicos problemas de transporte coletivo da cidade, sejam eles ciclistas, pedestres e passageiros, pertencentes a uma silenciosa maioria não organizada. Exemplos de linhas de atuação, pensamento e manifestações de algumas das ONGs de

\footnotetext{
${ }^{47}$ Pesquisa de Origem e Destino do Metrô de 2007 situou as viagens de bicicleta nas regiões de periferia.
} 
cicloativismo assim como troca de idéias de redes sociais encontram-se no ANEXO II ao final deste trabalho.

\subsubsection{A Origem do Movimento Cicloativista no Brasil e em São Paulo}

De acordo com Giselle Xavier ${ }^{48}$, apesar de ser difícil precisar o início do cicloativismo, ele teve suas raízes já nos anos oitenta: "F. José Lobo ou Zé Lobo (2007), presidente da Associação Transporte Ativo (TA), informou que no Rio de Janeiro, já nos anos oitenta, logo após voltarem do exílio na Europa, Alfredo Sirkis e Fernando Gabeira davam os primeiros passos do cicloativismo brasileiro: Eles traziam uma outra cultura de lá e já queriam implantá-la por aqui. Nessa época, em 1984, houve a primeira Bicicletada, pedalada que vinha pela Orla do Flamengo e ia até o Leblon, liderada por ambos. Por alguns anos muito pouco ouvi falar de ciclovias ou cicloativismo até que em 1990 em uma corrida de MTB (Montain Bike) em Teresópolis, fui dar um depoimento a um repórter da Bicisport. Ali pela primeira vez percebi o que era o cicloativismo, o repórter era o Arturo Alcorta ( Foto 2). Naquele dia ele me abriu os olhos para a bicicleta na cidade, que eu já utilizava, mas nunca tinha visto como um veículo! (LOBO, 2007).

Arturo, cicloativista desde o início dos anos oitenta, que coordena a Escola de Bicicleta, foi Bike Repórter da Rádio Eldorado FM, de 1999 a 2001. Ele veiculava informações pela rádio enquanto pedalava, entre as 18 e as 20 horas, diariamente, pelas ruas de São Paulo (GUERRERO, 2004). Sobre essa experiência e o cicloativismo no Brasil, ele manifestou: "Bike Repórter não vejo como cicloativismo, se bem que deu um resultado enorme neste sentido. O que fez sucesso é fato de que além dos boletins sobre o trânsito eu falava sobre a cidade, sobre a vida, pequenas coisas do dia a dia.

Na década de 70, Renata Falzoni utilizava a bicicleta como meio de transporte em São Paulo. Os passeios noturnos aconteceram quando Renata Falzoni escolheu a noite como sendo perfeita para pedalar, pois o número de veículos era reduzido. Em meados de 80 aquelas saídas noturnas não eram mais solitárias, Renata tinha companhia de vários amigos. Em 1989, estes passeios

\footnotetext{
${ }^{48}$ Xavier, Giselle Noceti Amon - "O Cicloativismo no Brasil e a produção da lei da Política Nacional de Mobilidade Urbana: estratégias, instituições e padrões de relação entre atores" - Universidade Federal de Sta. Catarina - Centro de Filosofia, Letras e Ciências Humanas -2007
} 
informais começaram a se expandir, e várias pessoas queriam pedalar nas condições de um Night Biker. Daí nasceu a idéia de criar o Night Biker's Club do Brasil, com o objetivo de fazer os passeios noturnos, ...Desde essa época, toda terça-feira, pontualmente às $21 \mathrm{hs}$, sai um passeio pela cidade de São Paulo."

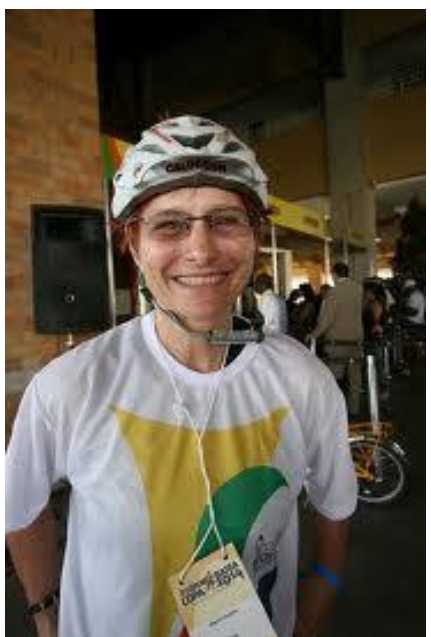

Foto 5 - Renata Falzoni (Sampa Bikers)

Fotos do banco de imagens Google

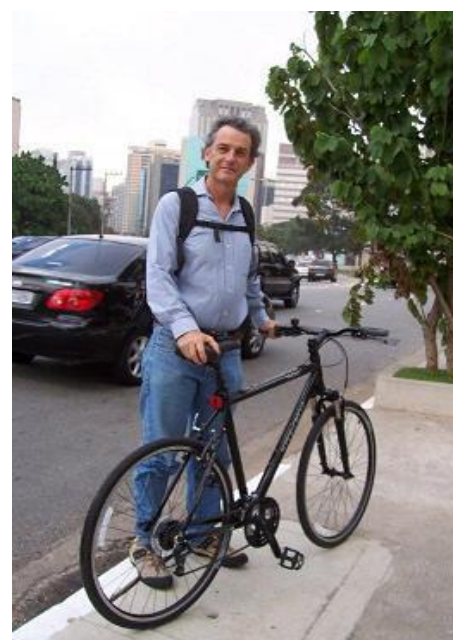

Foto 6 - Arturo Alcorta (Escola de Bicicleta)

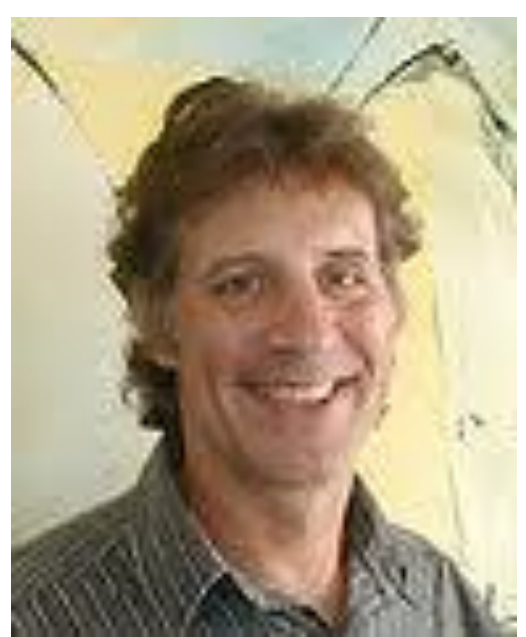

Foto 7 - Bill Presada (Bike Brasil)

O poder de mobilização e a articulação do cicloativismo nos vários canais de mídia é um dos principais mecanismos utilizados para fazer movimentar a inércia da máquina pública induzindo a reversão das políticas relativas à implantação de infraestrutura cicloviária. Pertencente às camadas de elite, os próprios cicloativistas tem consciência de que são minoria em relação à massa da população usuária da bicicleta, mas cientes do poder da organização e articulação da mobilização e conhecedores das dificuldades enfrentadas pelo ciclista cotidiano em São Paulo, formam uma linha de frente na conquista do espaço e dos direitos de todos os usuários de bicicleta independentemente se estes direitos comprometam os dos demais usuários da via.

Outro cicloativista, Bill Presada (Foto 3), da Associação Bike Brasil, assim expôs a história do cicloativismo em capítulo sobre este assunto no Caderno Técnico sobre Transporte Cicloviário da ANTP(2007) $)^{49}$ : “O aparecimento das primeiras bicicletas foi acompanhado da criação quase imediata de diversas associações, clubes e organizações, todos com o intuito de agrupar pessoas e apadrinhar idéias relacionadas àquela nova maravilha. 0 terceiro setor da bicicleta teve

\footnotetext{
49 “Caderno Técnico sobre Transporte Cicloviário" - ANTP - Presada, Bill - "Cicloativismo: A Expansão da Bicicleta" - 2007
} 
seu início, porém, apenas quando os ativistas sentiam necessidade de canais próprios, fora dos espaços governamentais oficiais e que seria melhor que $o$ próprio setor cuidasse de seus interesses, do que deixar isso para os outros." Presada atribui muita importância ao novo Código de Trânsito Brasileiro de 1997, que passa a legitimar a bicicleta como veículo e, portanto, como modo de transporte tanto para a sociedade como para o poder público. Desta forma as reivindicações destas organizações cicloativistas passam a ter amparo legal e, portanto, mais força para obrigar o poder público a assumir a gestão da circulação da bicicleta no planejamento e operação do trânsito nas cidades brasileiras. Presada ${ }^{50}$ relata como primeira grande ação cicloativista desta nova era, a organização de um grupo que em janeiro de 1998 saiu de Parati e pedalou durante 21 dias até Brasília em manifestação de apoio ao novo Código de Trânsito. Houve grande repercussão na mídia e até recepção pelo próprio presidente da república de então, Fernando Henrique Cardoso, no Palácio do Planalto.

Ele também ressaltou em seu artigo cobrança ao cumprimento de outras leis vinculadas ao uso cotidiano da bicicleta como fator de indução não só da transformação física das cidades, mas na promoção de uma revolução na cultura dos seus moradores.

\subsubsection{Massa Crítica / Bicicletada e o cicloativismo contemporâneo}

Atualmente muitas entidades de cicloativismo existentes em São Paulo são oriundas de movimentos iniciados em outros países. Um exemplo disto é a Bicicletada, um movimento que no Brasil e em Portugal foi inspirado na Massa Crítica - Critical Mass.

De acordo com um de seus primeiros membros, o jornalista e cicloativista Thiago Benícchio $^{51}$ (Foto 4) da ONG Ciclocidade, a primeira vez que se utilizou o nome Bicicletada "foi em julho de 2001, durante um protesto antiglobalização chamado para a mesma data de um encontro do G-8." Estes movimentos antiglobalização escolhiam datas específicas denominadas "Dias de Ação

\footnotetext{
50 "Caderno Técnico sobre Transporte Cicloviário" - ANTP - Presada, Bill - "Cicloativismo: A Expansão da Bicicleta" - 2007

${ }^{51}$ Benícchio, Thiago - artigo publicado no livro "Shift Happens! Critical Mass at 20 ": " Critical Mass is Dead. Long Live Critical Mass!" - Full Enjoyment Books, San Francisco, USA, 2012
} 
Global" que coincidiam com a agenda de encontros de entidades que surgiram através da ideologia neo-liberalista. Conforme relata Beníchio no mesmo artigo: "Aquelas pessoas (re)descobriram que resgatar as ruas em formas não tradicionais de protesto também eram boas formas de protestar. Carros de som com líderes partidários ou sindicais bradando discursos muitas vezes ininteligiveis ou massas segurando bandeiras e repetindo palavras de ordem pouco significativas eram substituídas por jogos de futebol na rua, pessoas distribuindo panfletos feitos em casa, black blocks ou mesmo festas de rua e bicicletadas ocupando o espaço público, bloqueavam a engrenagem do sistema $e$ contestavam a ordem do "novo" capitalismo financeiro. , onde ciclistas se juntam para reivindicar seu espaço nas ruas."

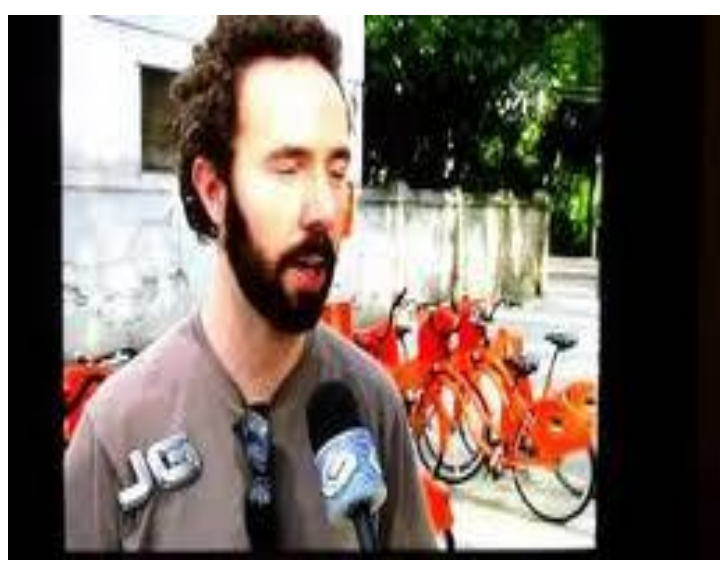

Foto 8 - Thiago Benícchio ONG Ciclocidade Fotos Banco de Imagens Google

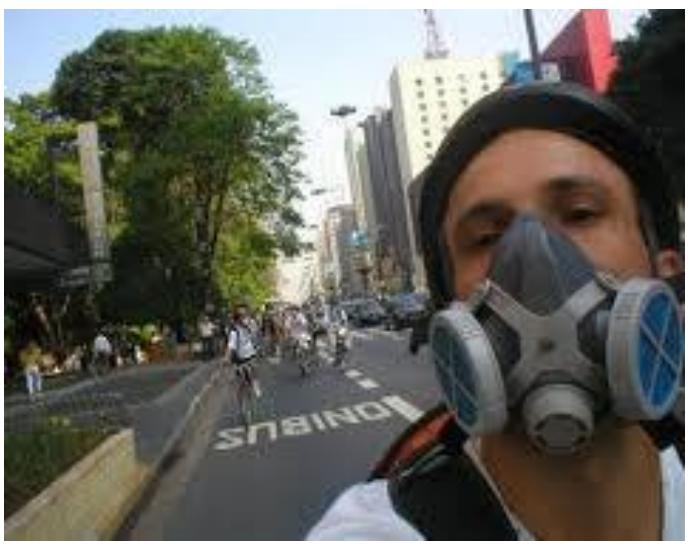

Foto 9 - André Pasqualini Blog Bicicreteiro

Trazida para São Paulo, a primeira bicicletada ocorreu, de acordo com Benicchio, no dia 22 de Setembro de 2004, durante a comemoração do Dia Mundial Sem Carro, sendo repetida nos anos subseqüentes.

Sem a presença de lideranças, seus participantes se comunicam através de redes sociais e páginas específicas para combinar eventos, alguns deles polêmicos, como a Pedalada Pelada na Av. Paulista (Foto 6), importada do World Naked Bike Ride.

Outras formas de protesto organizadas registram o "die in" deitando-se na pista ao lado de suas bicicletas ou deixando uma "ghost bike", uma bicicleta pintada de branco no local onde houve um acidente fatal com ciclista, conforme exibidos nas Fotos 6,7 e 8. 


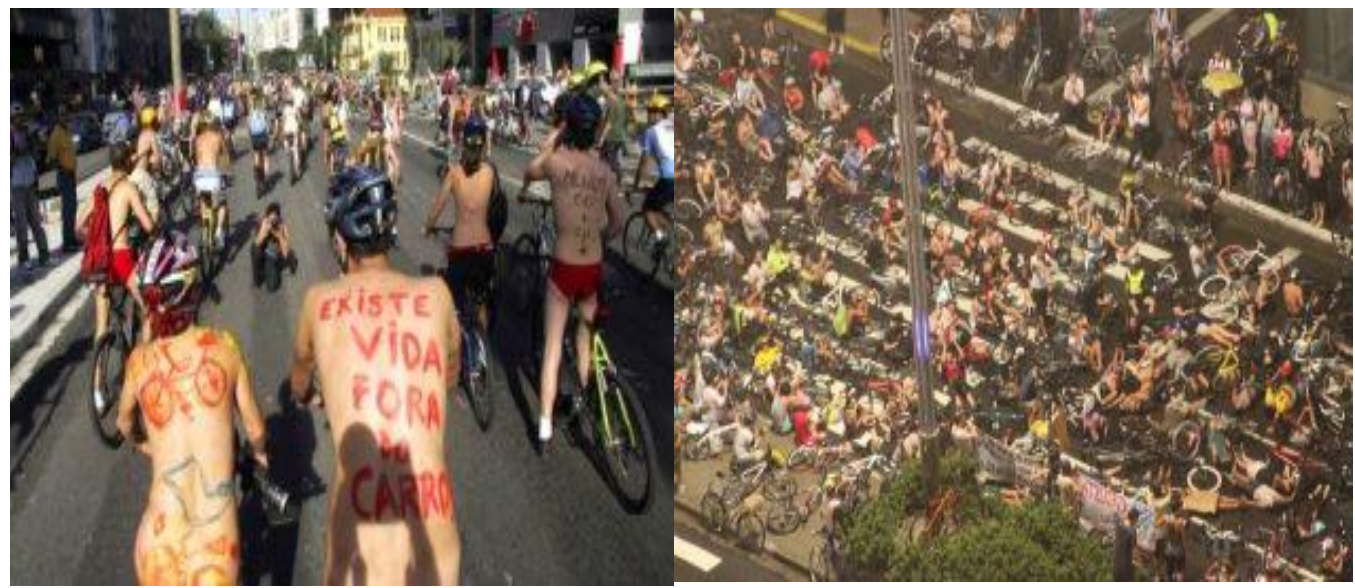

Foto 10 - "Pedalada Pelada"na Av. Paulista Foto 11 - "Die In" na Av. Paulista Fotos: site UOL

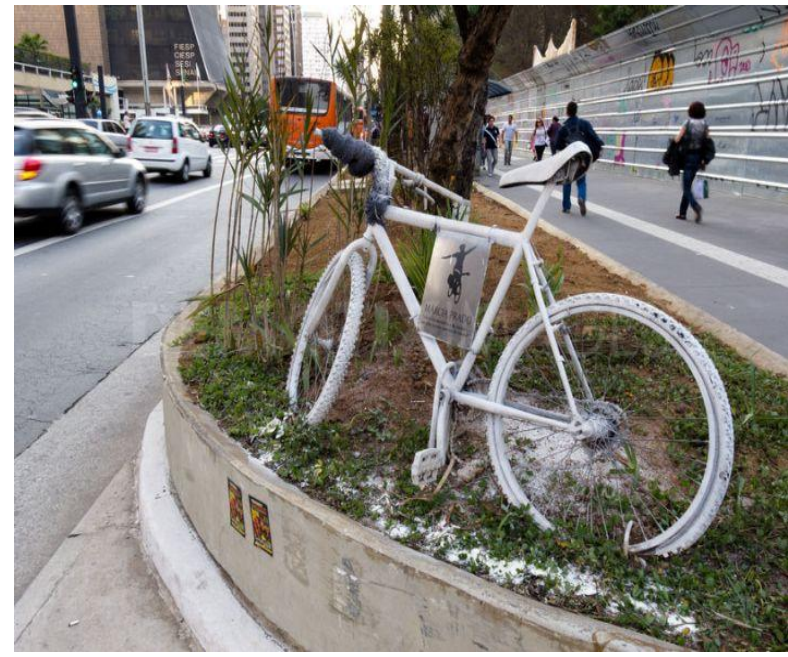

Foto 12 - "Ghost Bike" na Av. Paulista

Foto: site UOL

Além de manifestações os cicloativistas intervém visualmente nas ruas da cidade através da colocação de reproduções não oficiais da sinalização viária, chamando a atenção para os direitos dos ciclistas, reivindicando respeito à presença da bicicleta no trânsito (Figura 1 e Foto 9).

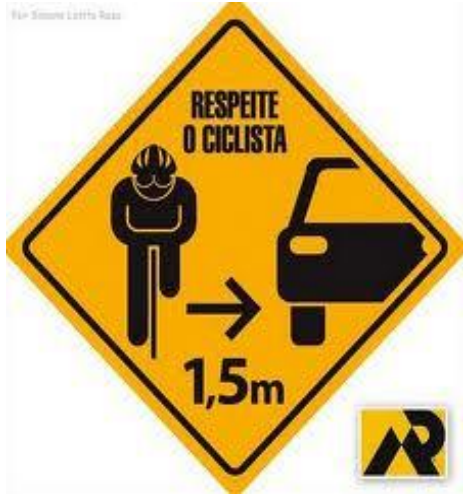

Figura 1 - Adaptação de sinalização viária em do atendimento à lei do CTB Figura e foto: Site pedalada

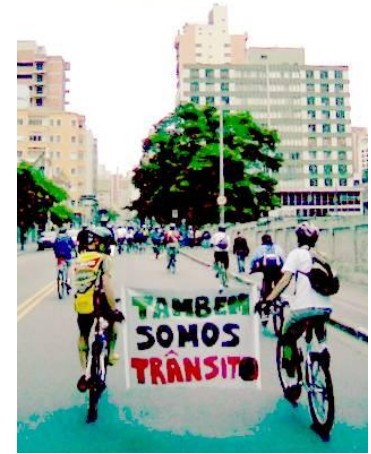

Foto 13 - Manifestação sobre aplicação CTB 
Ainda de acordo com Benícchio ${ }^{52}$, nos encontros entre cicloativistas existe a troca de experiências pessoais, dicas de manutenção mecânica do veículo, de caminhos mais tranqüilos, enfim, informações para tornar mais seguro o uso cotidiano da bicicleta. Estas trocas de experiência foram tão bem sucedidas que acabaram por gerar as oficinas "Mão na Roda" realizadas aos finais de semana em vários locais da cidade.

Outras iniciativas são constituídas por atividades de ciclistas voluntários que ajudam com os consertos mecânicos, ensinam a pedalar, orientam e acompanham pessoas que queiram utilizar a bicicleta no seu dia a dia, informando rotas mais seguras, os Bikeanjos.

Pelo seu poder de pressão e articulação, a administração pública tem procurado a aproximação com o movimento cicloativista no sentido de atender suas reivindicações e contar com eles em parcerias no desenvolvimento das ações voltadas às políticas públicas de transporte cicloviário, aproveitando o conhecimento influência destes grupos.

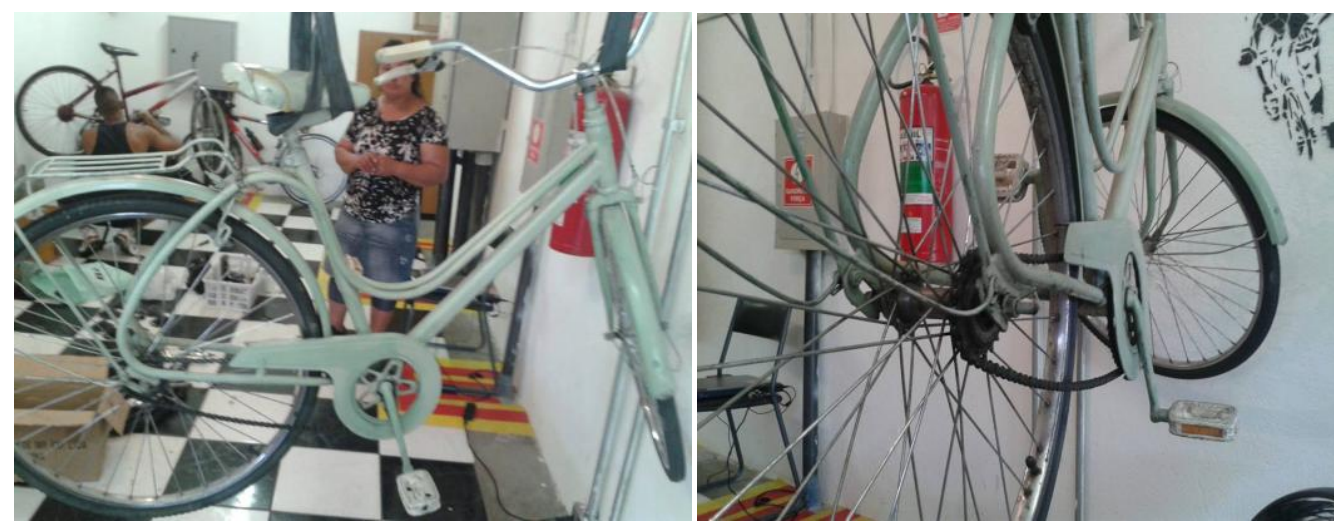

Foto 14 e Foto 15 - Oficina da Mão na Roda ZN

Foto: Roberson Miguel

Um exemplo é o curso para motoristas de ônibus da SPTrans elaborado e ministrado pelo cicloativista André Pasqualini (Foto 5), visando a redução da participação destes veículos em acidentes fatais com ciclistas. Outros grupos de cicloativismo também são convidados para participar de decisões da prefeitura integrando grupos e comissões como o Próciclista.

\footnotetext{
${ }^{52}$ Benícchio, Thiago - artigo publicado no livro "Shift Happens! Critical Mass at 20 ": " Critical Mass is Dead. Long Live Critical Mass!" - Full Enjoyment Books, San Francisco, USA, 2012
} 
Cabe lembrar, como já observado anteriormente, que o poder de pressão política destes grupos tem sido direcionado principalmente aos interesses dos setores que representam.

Não há registro, até o momento, de algum tipo de organização, iniciativa ou ação voltado à defesa e atendimento das necessidades do universo dos usuários cotidianos de bicicleta composto por ciclistas de baixa renda, como por exemplo, uma associação que defenda os interesses dos ciclistas usuários dos bicicletários das estações da CPTM para reivindicar ampliação do número de vagas dos lotados bicicletários. Também faltam "die in" ou "ghost bikes" colocadas nas avenidas de periferias em solidariedade aos ciclistas mortos por lá.

Estes usuários por sua vez, pertencem aos setores sociais mais exigidos pelo sistema produtivo e menos informados de seus direitos e prerrogativas. Vivenciam um estilo de vida onde, infelizmente, não há consciência política, tempo e energia para a prática do ativismo político.

\subsubsection{O cicloativismo mercadológico como elemento indutor de negócios, empresas e parcerias entre o poder público e iniciativa privada}

Outro aspecto importante do cicloativismo vincula-se ao setor de serviços e marketing em função do potencial de negócios gerados "que vê neste movimento canais para concretizar investimentos do setor privado $e$ empresarial voltado à bicicleta e ao transporte ciclístico" (Presada, 2007) ${ }^{53}$. 0 valor agregado decorrente da imagem simpática, moderna e politicamente correta da bicicleta e do seu significado na ideologia ambientalista e da sustentabilidade, é fator decisivo para garantir a aceitação e o consumo de qualquer produto ou serviço a ela associados.

Por este motivo o discurso e a postura cicloativista são largamente utilizados nas ações de marketing e geração de renda por empresas vinculadas a sistemas produtivos cuja natureza é totalmente oposta à causa ambientalista, como é o caso de financeiras, bancos, seguradoras ( se formos lembrar é justamente o que o cicloativismo gerado pelo Movimento Critical Mass rejeitava - ver item 4.3.2). Às bem intencionadas atividades que oferecem de estímulo ao uso da

\footnotetext{
53 “Caderno Técnico sobre Transporte Cicloviário" - ANTP - Presada, Bill - " Cicloativismo: A Expansão da Bicicleta" - 2007
} 
bicicleta como transporte para o dia a dia, estas empresas agregam suas marcas em serviços de compartilhamento de bicicletas, ou patrocínio de atividades ciclísticas de lazer e até mesmo das ONGs de cicloativismo (exemplos: Ciclocidade, Vadebike).

O cicloativismo mercadológico (ou marketing) é uma boa solução encontrada pelas empresas e agências de publicidade para contornar a rigidez da legislação municipal de paisagem urbana ( ou Lei da Cidade Limpa ${ }^{54}$ ) que impõe forte restrição de publicidade visual na cidade com a finalidade de preservar a paisagem urbana.

Dois bons exemplos são os serviços de empréstimo de bicicletas. 0 primeiro dele iniciado em 2008 envolvia algumas estações de metrô (Foto 12), era administrado pela ONG Parada Vital, sob o patrocínio da Porto Seguro Seguradora e consistia no empréstimo de bicicletas gratuitamente na primeira meia hora e cobrança por cartão de crédito nas horas subsequentes.

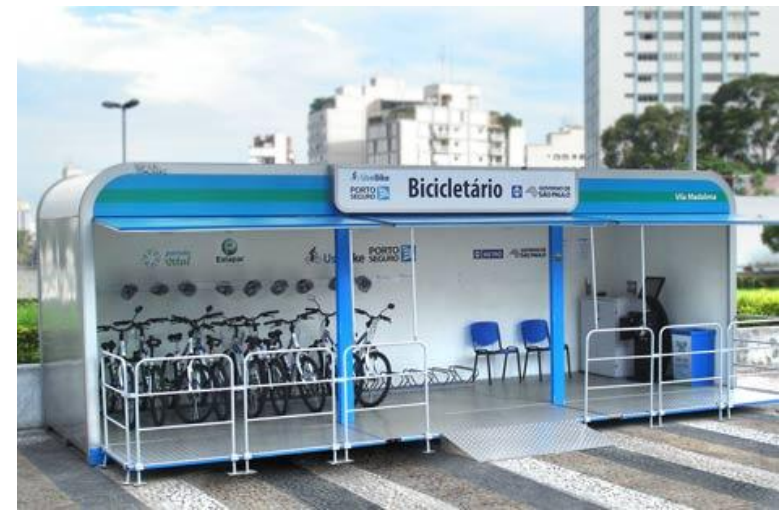

Foto 16: Bicicletário Estação Metrô Vila Madalena em 2008 - atualmente desativado Foto: Banco de imagens Google

Passou posteriormente para o patrocínio da SABESP, que depois de algum tempo também abandonou o projeto obrigando a administração do Metrô a desativá-lo temporariamente em quase todas as estações, com exceção das estações Anhangabaú, Butantã, Guilhermina-Esperança e Palmeiras-Barra Funda: "4 dos 17 bicicletários localizados em estações do metrô de São Paulo estão em funcionamento. O restante está fechado devido a problemas operacionais. De acordo com o Metrô, há pelo menos três meses estão sendo registradas reclamações de usuários em relação à qualidade de atendimento que é realizado desde $2008 " 55$

\footnotetext{
${ }^{54}$ Lei Cidade Limpa(Lei Municipal 14.222/06 em vigor desde 1ㅇ de janeiro de 2007 - ver Anexo I - Legislação Municipal

${ }^{55}$ Folha de SP - "Só 4 de 17 bicicletários ainda funcionam nas estações de metrô" - 15/01/2013
} 
Posteriormente o Metrô viabilizou a reativação deste serviço e até a conclusão deste trabalho não havia entrado em funcionamento em todas as estações. Outro serviço de bicicletas compartilhadas é semelhante ao Vélibe de Paris ${ }^{56}$. Trata-se de uma parceria entre a prefeitura e o Banco Itaú, denominado Bikesampa. No primeiro ano de funcionamento dotou a cidade com 100 pontos de aluguel de bicicletas com dez bicicletas cada um (Foto 13), situados em bairros de classe média e média alta, que rodeiam o Parque do Ibirapuera (Figura 2).

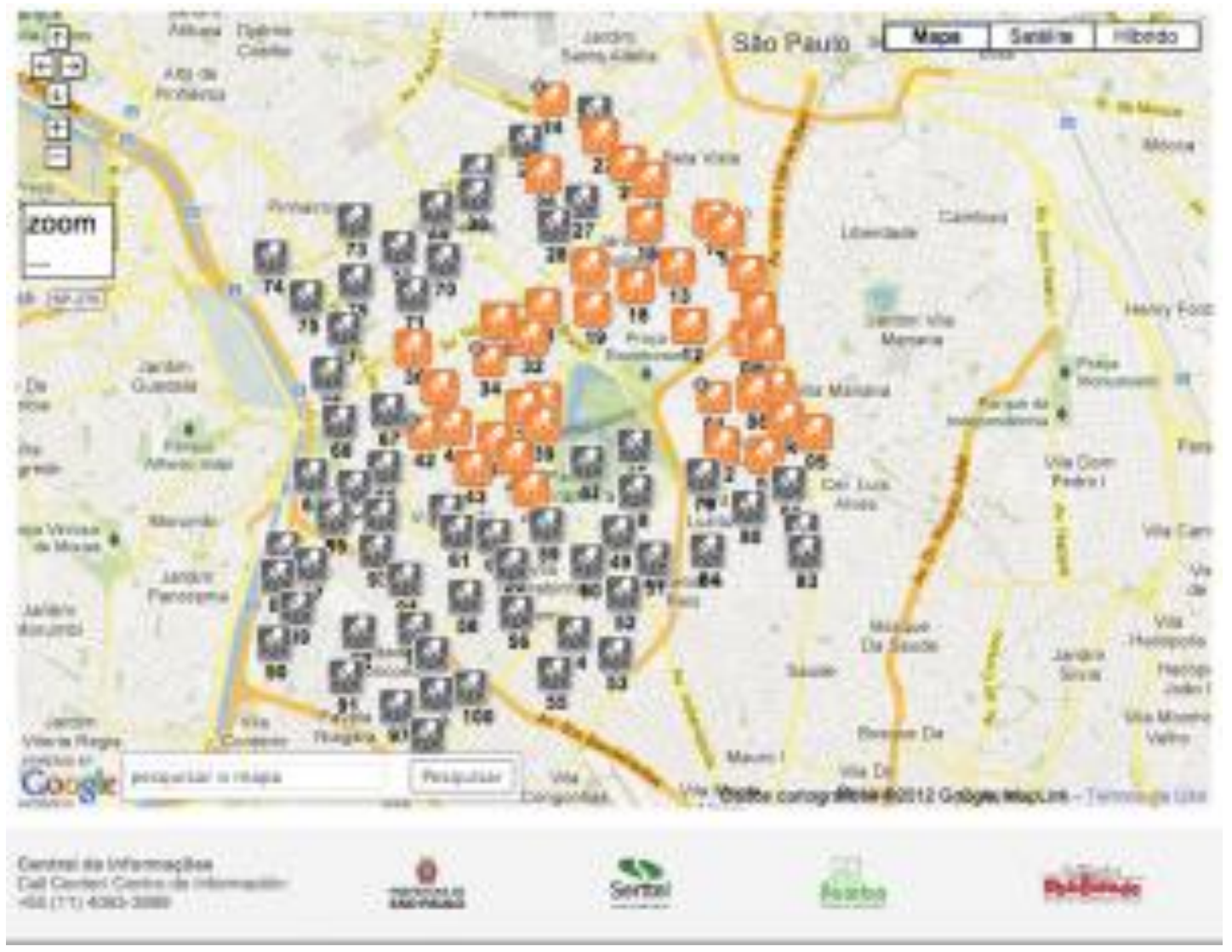

Figura 2 - Região de contorno do Pq. Ibirapuera com as 100 primeiras estações do Bikesampa

Fonte: Site do Bikesampa

Para possibilitar sua utilização, o usuário deveria se cadastrar baixando um aplicativo para smartphone, depositar um valor caução de $\mathrm{R} \$ 10,00$ e ter condições de arcar com a tarifa de R\$ 5,00 a cada meia hora de utilização que excedesse a primeira meia hora gratuita. A intenção da cobrança foi o estímulo à rotatividade do sistema e o seu direcionamento às viagens internas de curta extensão, em especial integradas às redes de transporte coletivo, o que

\footnotetext{
${ }^{56}$ Vélibe foi o primeiro sistema de bicicletas públicas de empréstimo implantado em Paris em 2007 sustentado por publicidade.
} 
justificou a localização dos pontos de empréstimo próximos a corredores de ônibus e linhas de metrô. Atualmente este serviço está sendo expandido para a Área Central e Zona Leste, com previsão de implantação de mais 200 estações até o final de 2013, além de integrar-se aos sistemas de transporte através da utilização do Bilhete Único (ver itens 5.4.2 e 6.2).

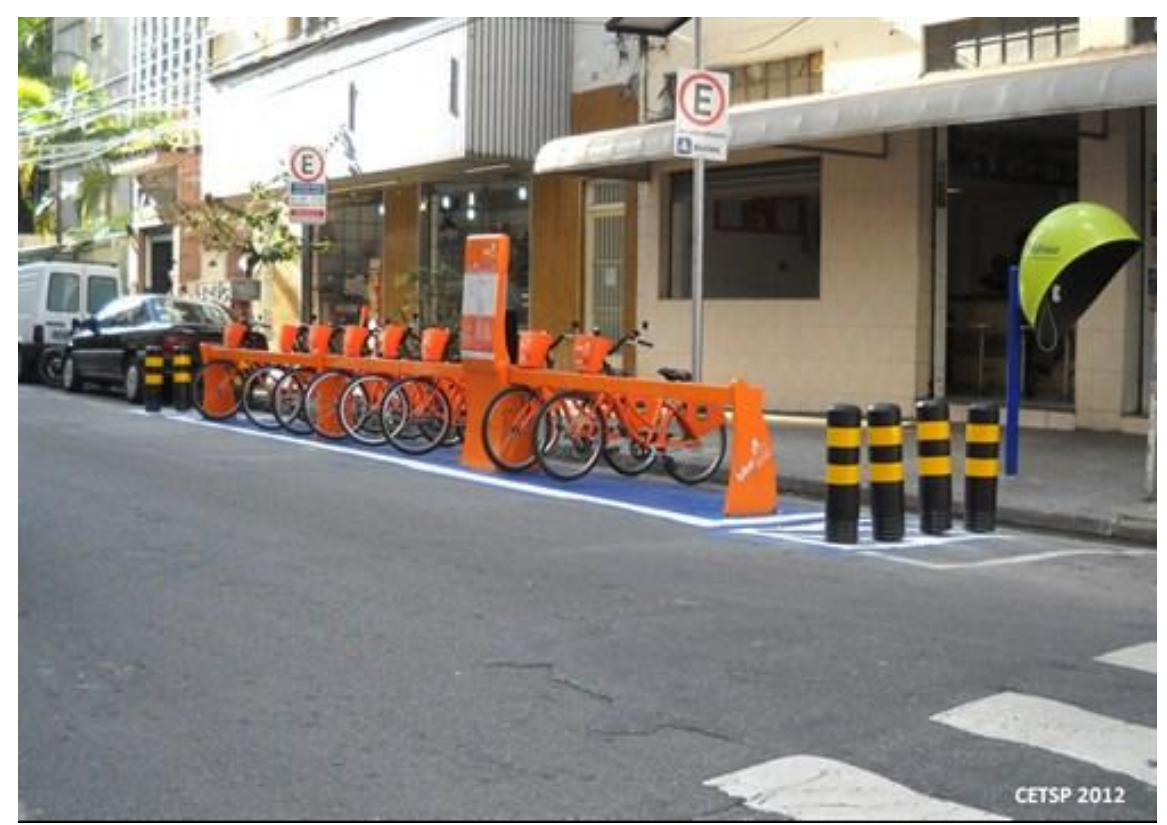

Foto 17 - Exemplo de estação do Bikesampa com 10 bicicletas Foto: Site da CET

Mais um exemplo significativo de marketing vinculado à imagem da bicicleta são as populares Ciclofaixas de Lazer, patrocinadas pela Bradesco Seguros, organizadas e operadas pela Companhia de Engenharia de Tráfego em parceria com a Secretaria Municipal de Esportes.

Com o objetivo de proporcionar lazer seguro e saudável à população pelo uso da bicicleta e ao mesmo tempo trabalhar princípios da educação de trânsito voltada à sua utilização, os atuais $120 \mathrm{Km}$ de ciclofaixas de lazer envolvem, aos domingos e feriados, uma megaoperação de tráfego com 9 horas de duração (das 7 às 16 horas) recrutando recursos materiais e humanos majoritariamente arcados com o patrocínio da Bradesco Seguros, envolvem também verba pública. Atualmente a função de lazer que ela proporciona tornou-a uma das opções de recreação favoritas da população, com frequêencia estimada em 150 mil usuários por domingo ${ }^{57}$ de acordo com o patrocinador.

\footnotetext{
${ }^{57}$ Site Ciclofaixa de Lazer: www.ciclofaixa.com.br
} 


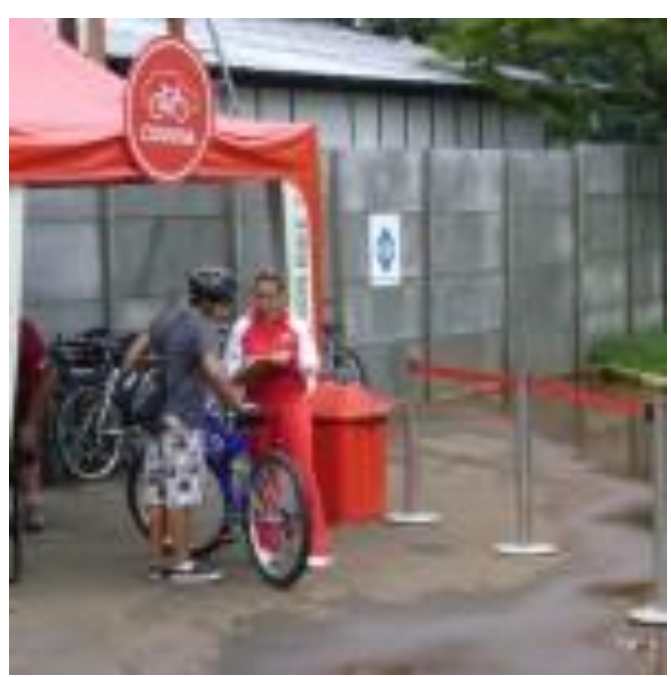

Foto 18 - Tenda de apoio mecânico Fotos: site da Ciclofaixa de Lazer

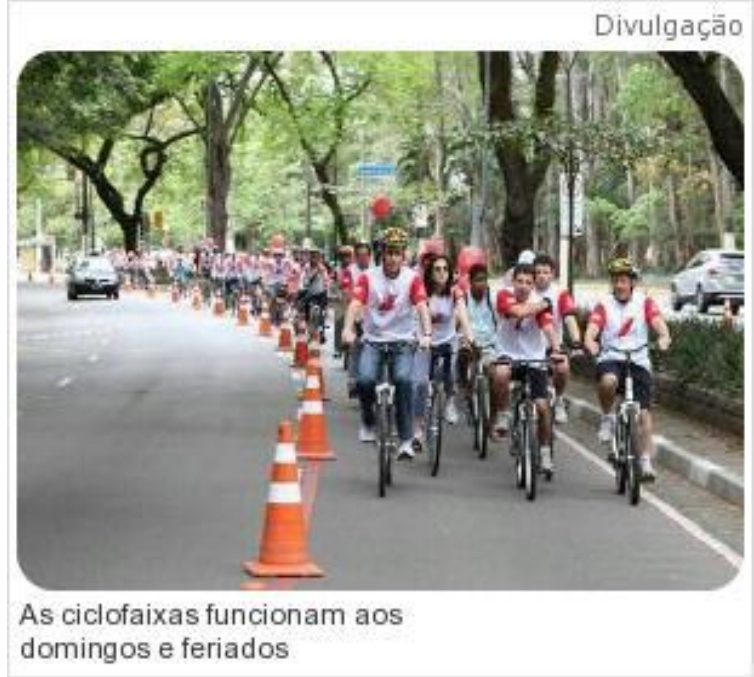

Foto 19 - Trecho da Ciclofaixa de Lazer

Cabe aqui também destacar a forma encontrada pela empresa patrocinadora para contornar a impossibilidade legal de exibir a sua marca na sinalização de trânsito envolvida: sua substituição por um logotipo neutro, criado especialmente para o evento denominado "Conviva" e utilizando as cores da marca da empresa, providencialmente as cores estabelecidas pela legislação de trânsito (CTB) para a sinalização cicloviária (vermelho).

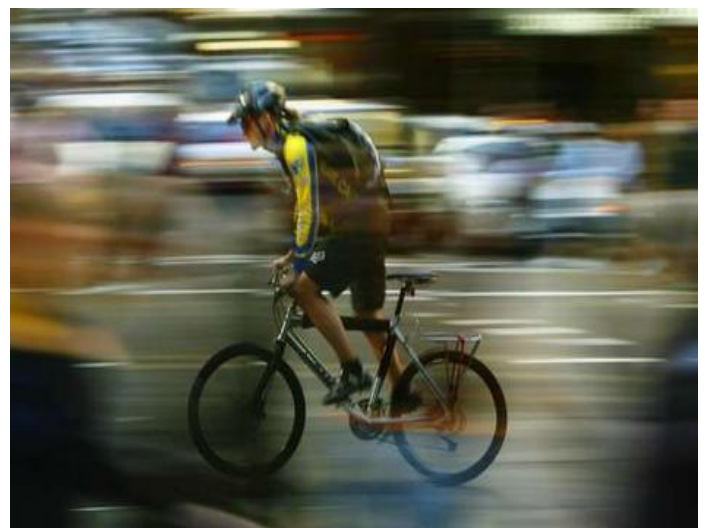

Foto 20 - Entregador da Bike Courier Foto: site Bike courier

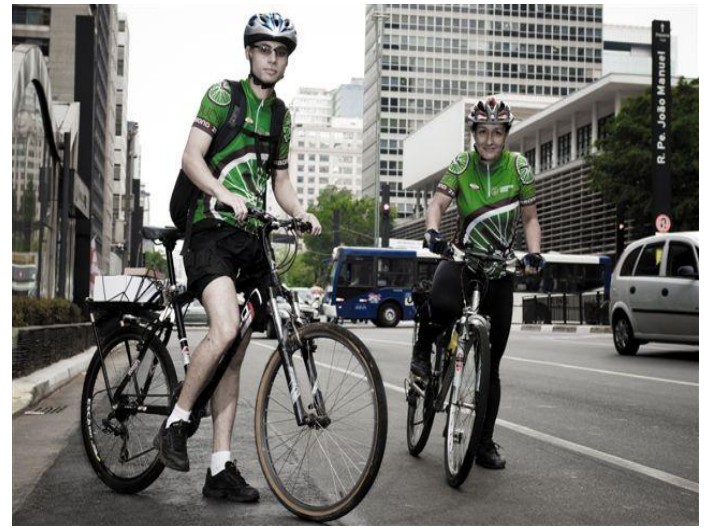

Foto 21 - Entregadores da Carbono Zero Foto: Site da Carbono Zero

Outro produto de mercado do cicloativismo é o constituído por pequenas empresas de prestação de serviços sob a ideologia ambientalista, baseadas no transporte cicloviário.Enquadram-se neste caso as empresas de entrega de 
mercadorias por bicicleta, ou bicifrete, como é o caso da Bikeboys e a Carbono Zero Courrier. 0 apelo ambientalista implica na publicação mensal sobre a quantidade de gases tóxicos que deixaram de ser emitidos na cidade com os quilômetros rodados pelas entregas por bicicleta feitas por elas.

Mais um ramo de negócio oriundo da postura cicloativista é referente ao planejamento e projetos urbanos de mobilidade não motorizada Alguns escritórios de arquitetura e urbanismo e profissionais de desenho urbano oferecem seus préstimos às prefeituras e empresas, para consultoria e desenvolvimento de planos e projetos cicloviários como, por exemplo, a TC Urbes (Figura 3).

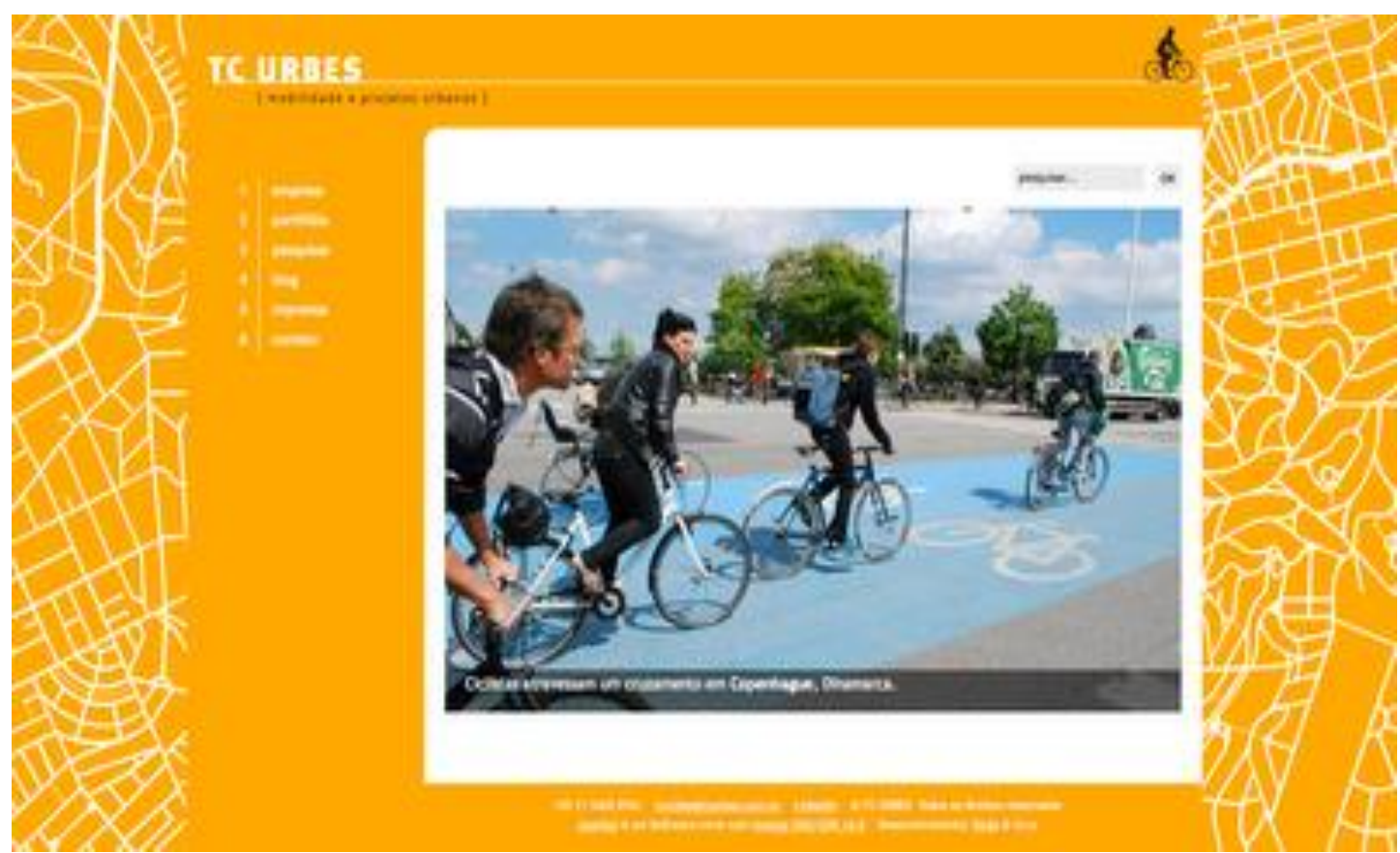

Figura 3 Portfólio do escritório TC Urbes - especialização em projetos cicloviários Fonte: Site TC Urbes

Finalmente, como último exemplo de atividade econômica derivada do cicloativismo, registra-se o serviço de cadastramento e mapeamento de rotas utilizadas por ciclistas nas cidades. 


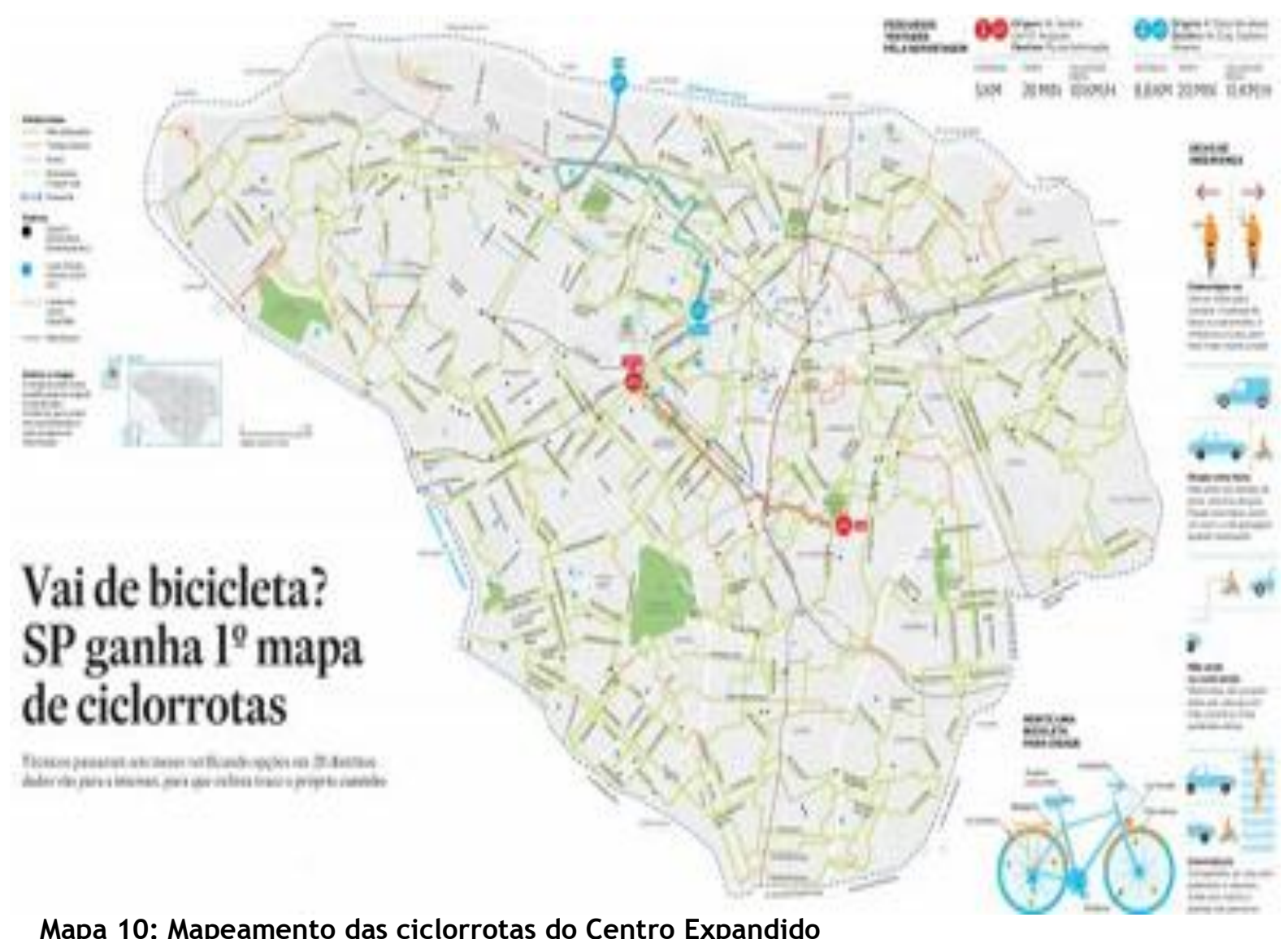

Mapa 10: Mapeamento das ciclorrotas do Centro Expandido

Foto: Jornal o Estado de São Paulo

Em São Paulo esta atividade foi iniciada primeiramente pelo cicloativista Arturo Alcorta em 2003, contratado pela Secretaria Municipal do Verde e Meio Ambiente - SVMA para traçar os primeiros trajetos utilizados por ciclistas nos bairros situados na Bacia do Rio Pinheiros, gerando um folder para distribuição na própria secretaria.

Anos mais tarde, em 2010 vários ciclistas urbanos foram contratados pela Secretaria Municipal de Esportes, Lazer e Recreação através do instituto CEBRAP - Centro Brasileiro de Planejamento - para elaborar mapeamento das rotas utilizadas por ciclistas no dia a dia, denominadas de ciclorrotas. O produto, um mapa (Mapa 9) com as rotas restringiu-se à área interna ao Centro Expandido, deixando fora as regiões onde ocorre o maior número de viagens de bicicleta. Este mapeamento além de ser utilizado pela própria prefeitura para a sinalização destas rotas de bicicleta está disponibilizado para consulta pela população através de site específico. Em meados 2013 o CEBRAP mapeou, a pedido do sistema de bicicletas compartilhadas Bikesampa, o mapeamento das rotas ciclísticas situadas no eixo Leste da cidade para apoiar a circulação dos usuários deste sistema. 
Além dos casos citados há vários outros cicloativistas empresários, proprietários de bicicletarias, cafés e outros pequenos negócios visando como clientes adeptos do transporte cicloviário, muitos dos quais operando somente na web.

\subsubsection{A Ascobike e o bicicletário de Mauá: um caso de cicloativismo espontâneo}

Ao contrário dos demais movimentos cicloativistas trazidos do exterior, a Ascobike foi originada a partir de demanda local e espontânea, gerada por problemas de transporte, também existentes no município de Mauá. Por este motivo, apesar de situada fora dos limites da área de estudo deste trabalho, (Município de São Paulo) foi incluída nele.

A cidade de Mauá, situada na região metropolitana de São Paulo não tem, até o momento, qualquer infraestrutura para circulação de bicicletas. Seu relevo é acidentado e conta um serviço de transporte coletivo por ônibus, que não atende adequadamente às necessidades de deslocamento diário da população, gerando assim, como no caso de São Paulo, uma demanda para uso da bicicleta na integração modal pela estação da CPTM ou resolver problemas particulares pois esta estação está situada na área central.

A Tabela 7 já apontou a cidade de Mauá com um total de quase três mil viagens diárias de bicicleta em 2007, cujos motivos estão praticamente distribuídos entre os motivos "trabalho" e "outros". Este último engloba saúde, assuntos pessoais, compras e procura de emprego.

Desta forma surge a "ASCOBIKE - Associação dos Condutores de Bicicletas - uma organização não governamental, fundada em 2001 pelo ferroviário Adilson Alcantara, funcionário da Companhia de Trens Metropolitanos (CPTM), que nessa época ocupava o cargo de chefe da estação e foi encarregado de encontrar uma solução para 200 bicicletas que ficavam precariamente amarradas todos os dias nas grades da estação do município de Mauá, dificultando a circulação de pedestres e passageiros. A solução encontrada foi organizar os ciclistas, fundar uma associação e construir um local adequado ao estacionamento de bicicletas, onde as pessoas, em sua maioria usuárias do trem, pudessem deixá-las com segurança. Foi solicitada à CPTM a concessão de uma área ociosa, vizinha à estação, localizada sob a passarela de pedestres, para abrigar o bicicletário. 
Assim nasceu a ASCOBIKE, e o acordo para concessão do espaço foi firmado. Desde então, o número de adeptos da bicicleta no município tem aumentado de forma significativa, e recentemente a CPTM reformou o bicicletário com o objetivo de adequar sua capacidade à demanda crescente, mantendo, porém, os padrões operacionais.

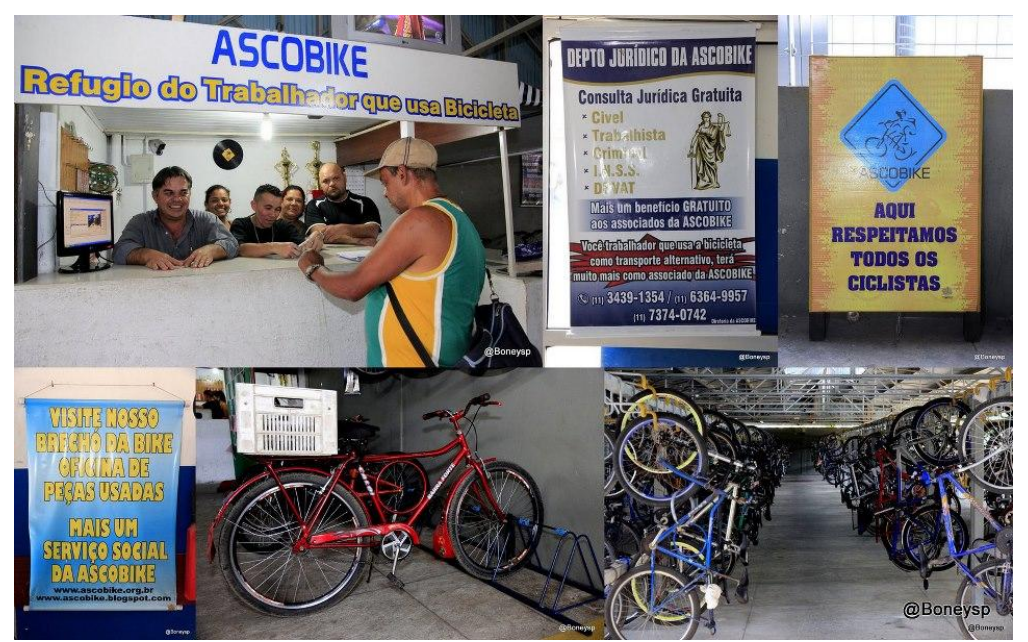

Foto 22 - Registro do cotidiano na Ascobike com os serviços disponíveis aos usuários Foto: Facebook da Ascobike

Além da segurança ao estacionar sua bicicleta, a associação oferece diversos serviços ao usuário: banheiro feminino e masculino, empréstimo e manutenção de bicicletas, café e água, apoio jurídico e serviço de assistência social. 0 bicicletário, que começou com aproximadamente 200 bicicletas, atende hoje cerca de 2.000 usuários diariamente e é o maior bicicletário das Américas. "58 De acordo com informações da própria Ascobike, o bicicletário permanece aberto 24 horas por dia e 365 dias por ano e atende necessidades específicas de seus usuários tais como:

- Vagas especiais para mulheres e idosos (que não tem força física para pendurar bicicletas no sistema de gancho);

- Serviços de manutenção e revisão de bicicletas por um valor menor do que o praticado no mercado, que também capacita jovens da comunidade em situação de risco;

- Café e água gratuitos;

- Material para engraxe de sapatos;

\footnotetext{
${ }^{58}$ Alcântara, Adilson; Hagen, Jonas e outros “Manual de bicicletários modelo ASCOBIKE” - 2009
} 
- 22 bicicletas para empréstimo gratuito no período de reparo da bicicleta do associado;

- Brechó da Bike, para reaproveitamento de peças usadas.

- Passeios ciclísticos com a finalidade de paz e educação no trânsito.

Desta forma a Ascobike, que foi criada para solucionar problema de guarda de bicicletas, acaba se tornando um ponto de referência para seus usuários que encontram serviços, apoio jurídico e social e ponto de encontro e poderia servir de referência para o trabalho do cicloativismo.

\subsubsection{0 cicloativismo e seu reflexo nas políticas cicloviárias paulistanas}

As situações relatadas permitem perceber que o exercício do cicloativismo no município de São Paulo está majoritariamente concentrado no público constituído de jovens e adultos com nível universitário. Divulgam um estilo de vida independente e com qualidade e cobram do poder público a garantia de desfrutar de seus direitos enquanto cidadãos e ciclistas, muito embora muitos estejam menos preocupados com o exercício dos seus deveres. 0 Anexo II deste trabalho concentra material que reproduz o pensamento do movimento cicloativista paulistano e foi recolhido nos sites de cicloativismo e diálogo de redes sociais.

Os cicloativistas buscam também destaque no seu meio, principalmente em grupos sociais da internet, ao se tornarem formadores de opinião, tanto individualmente como em grupo, pelo envolvimento à uma causa simpática, politicamente correta e de grande contemporaneidade. Neste ambiente social, o movimento cicloativista acaba se tornando a mola propulsora responsável pela discussão do uso da bicicleta no município. Apesar de estar em grande parte direcionado para seus próprios interesses, acaba por abranger toda a população inclusive a grande maioria dos usuários de bicicleta que não são cicloativistas e nem participam de nenhuma de suas ações.

Por outro lado, o fato do cicloativismo não ser um movimento genuinamente brasileiro e paulistano, reforça o interessante fato de ser deflagrado em ambiente circunstancial e por motivação político-cultural totalmente diversa dos seus países de origem uma vez que neles inexistem os crônicos problemas de mobilidade cotidiana. Neles a bicicleta personifica uma forma de vida que se 
opõe à selvageria da economia pós-moderna e ao massacre do processo produtivo imposto pelo capitalismo e pela globalização.

Exercidos majoritariamente por setores específicos e privilegiados da sociedade paulistana, sem sombra de dúvidas a ação política do cicloativismo acaba conseguindo intimidar e movimentar a inércia da máquina pública na implementação de ações e programas para viabilizar o uso da bicicleta na agenda do poder público e até em campo territorial que extrapola os limites dos locais visados por este grupo específico.

Como ultima observação, não deve ser esquecido o imenso potencial de negócios intrínseco ao produto mercadológico que busca na imagem moderna e alternativa da bicicleta um "valor agregado" aos seus frutos, criando e acelerando assim a máquina da economia. 
CAPÍTULO 5

\section{AS INFRAESTRUTURAS CICLOVIÁRIAS EXISTENTES NO MUNICÍPIO DE SÃO PAULO}




\section{AS ATUAIS INFRAESTRUTURAS CICLOVIÁRIAS DO MUNICÍPIO DE SÃO PAULO}

A partir de 2005, a gestão municipal que iniciou seu período administrativo tinha como uma de suas diretrizes de mobilidade estimular e consolidar o uso da bicicleta como modo de transporte, certamente motivada por ações e programas que já repercutiam pelo país ${ }^{59}$. Além disso, havia a pressão popular para cumprimento das diretrizes cicloviárias previstas nos planos estratégicos regionais definidos pelo Plano Diretor de 2002.

Assim áreas da prefeitura que já haviam se debruçado anteriormente sobre o assunto retomaram estudos antigos e os atualizaram a partir dos dados da recalibragem da Pesquisa de Origem e Destino do Metrô (Mini-OD) feita em 2002, conforme exposto no item 4.2.3.

Posteriormente a realização da Pesquisa de Origem e Destino do Metrô em 2007 confirmou a tendência do aumento das viagens ciclísticas paulistanas já constatada pela Mini OD de 2002 e justificou a retomada dos estudos para desenvolvimento e implantação de infraestruturas cicloviárias pelo poder público . Apesar de não ser realizada especificamente com a finalidade de aferir a mobilidade por bicicleta, a Pesquisa de Origem e Destino do Metrô possibilitava identificar as macro-regiões da cidade com demanda ciclística e assim fornecer diretrizes para definições territoriais para as políticas cicloviárias ora em curso. Entretanto a necessidade de dar uma resposta política à pressão da sociedade e o pouco conhecimento técnico sobre o assunto resultaram em algumas experiências precipitadas e mal sucedidas como foi o caso da Ciclovia da Estrada da Colônia. Implantada em 2006 foi desativada cinco anos depois em 2011, em decorrência de acidentes veiculares a ela atribuídos ${ }^{60}$ : "Com custo de $R \$ 200$ mil, foi construída ao lado da estrada, separada dos carros apenas por pequenos blocos de concreto. Ligava os bairros de Vargem Grande e Colônia ao centro de Parelheiros e era bastante usada por ciclistas....A Prefeitura alega

\footnotetext{
${ }^{59}$ Criação do GT Bicicleta na ANTP em 2003, criação do Programa Bicicleta Brasil pelo Ministério das Cidades em 2004

${ }^{60}$ O Estado de São Paulo - 29/03/2011 - Prefeitura desativa ciclovia em Parelheiros
} 
que a demolição foi pedida pelo Ministério Público Estadual (MPE), que havia aberto inquérito para investigar acidentes na via."

Este fato e os demais relatados ao longo deste capítulo apontam para a falta de planejamento que caracterizou o início da retomada da política cicloviária municipal, fazendo com que os parcos recursos públicos fossem direcionados para custear infraestruturas cicloviárias nos poucos espaços disponíveis da intensamente ocupada malha viária paulistana, independentemente de sua localização em relação à demanda ciclística, resultando em intervenções tímidas, descontínuas e pouco utilizadas.

Esta característica também compromete a eficácia de algumas recentes infraestruturas cicloviárias implantadas em parceria com a iniciativa privada, os sistemas de bicicletas compartilhadas, que ainda são subutilizados porque a maioria da população se sente desencorajada a pedalar sem haver espaço exclusivo destinado às bicicletas. Os que se atrevem, por sua vez, exigem medidas para tornar possível sua sobrevivência e integridade física através de programas e ações que tropeçam em problemas ainda não bem resolvidos em relação à legislação que institui normas para a convivência da bicicleta e demais usuários da via.

Entretanto mesmo com todos estes aspectos restritivos, não há como negar que a bicicleta entrou definitivamente na agenda das políticas de transporte do município de São Paulo. 


\subsection{Situação atual da infraestrutura cicloviária do Município de São Paulo - Data de referência: março de 2013:}

O Município de São Paulo conta atualmente com uma rede de infraestrutura cicloviária de circulação cotidiana composta por ciclovias, ciclofaixas e ciclorrotas que totalizam 125,3 Km. Somadas a elas operam aos domingos e feriados, das 07:00 às 16:00 horas, mais $120 \mathrm{Km}$ de ciclofaixas de lazer. Possibilitando a integração modal desta rede aos sistemas de transporte público em terminais e estações do Metrô, CPTM, SPTrans e EMTU existem atualmente 61 bicicletários e paraciclos que disponibilizam quase cinco mil vagas de bicicletas.

Nesta extensão das infraestruturas estão contabilizadas ${ }^{61}$ :

- infraestruturas de circulação de caráter definitivo e exclusivas para bicicletas: $64 \mathrm{Km}$ de ciclovias e 3,3 Km de ciclofaixas ;

- infaestruturas de circulação de caráter definitivo e não exclusivas para bicicletas: $58 \mathrm{Km}$ de ciclorrotas;

- infraestruturas de estacionamento para bicicletas compostas por bicicletários e paraciclos nas estações da CPTM, Metrô, EMTU e terminais da SPTrans totalizando 61 pontos com quase 5 mil vagas;

- estações de bicicletas públicas em estações de metrô e em vias da cidade totalizando mais de 150 locais, sendo que em algumas estações de metrô, este serviço se encontra temporariamente desativado por problemas contratuais.

Este total de extensão de infraestrutura de circulação cicloviária ainda é tímido se comparado à extensão da malha viária paulistana, ou seja, 0,7\% dos aproximados $17.000 \mathrm{Km}$ mil quilômetros de vias existentes na cidade (curiosamente coincidente com o porcentual de viagens ciclísticas diárias na matriz modal 0,6\%). Entretanto a maioria da infraestrutura cicloviária de circulação atualmente implantada não está nas áreas de maior demanda de

\footnotetext{
${ }^{61}$ Informações fornecidas pela CET - Companhia de Engenharia de Tráfego / Departamento de Planejamento Cicloviário em agosto de 2013
} 
viagens cotidianas de bicicletas apontadas nos mapas 3 e 3.1, conforme pode ser constatado no Mapa 10.

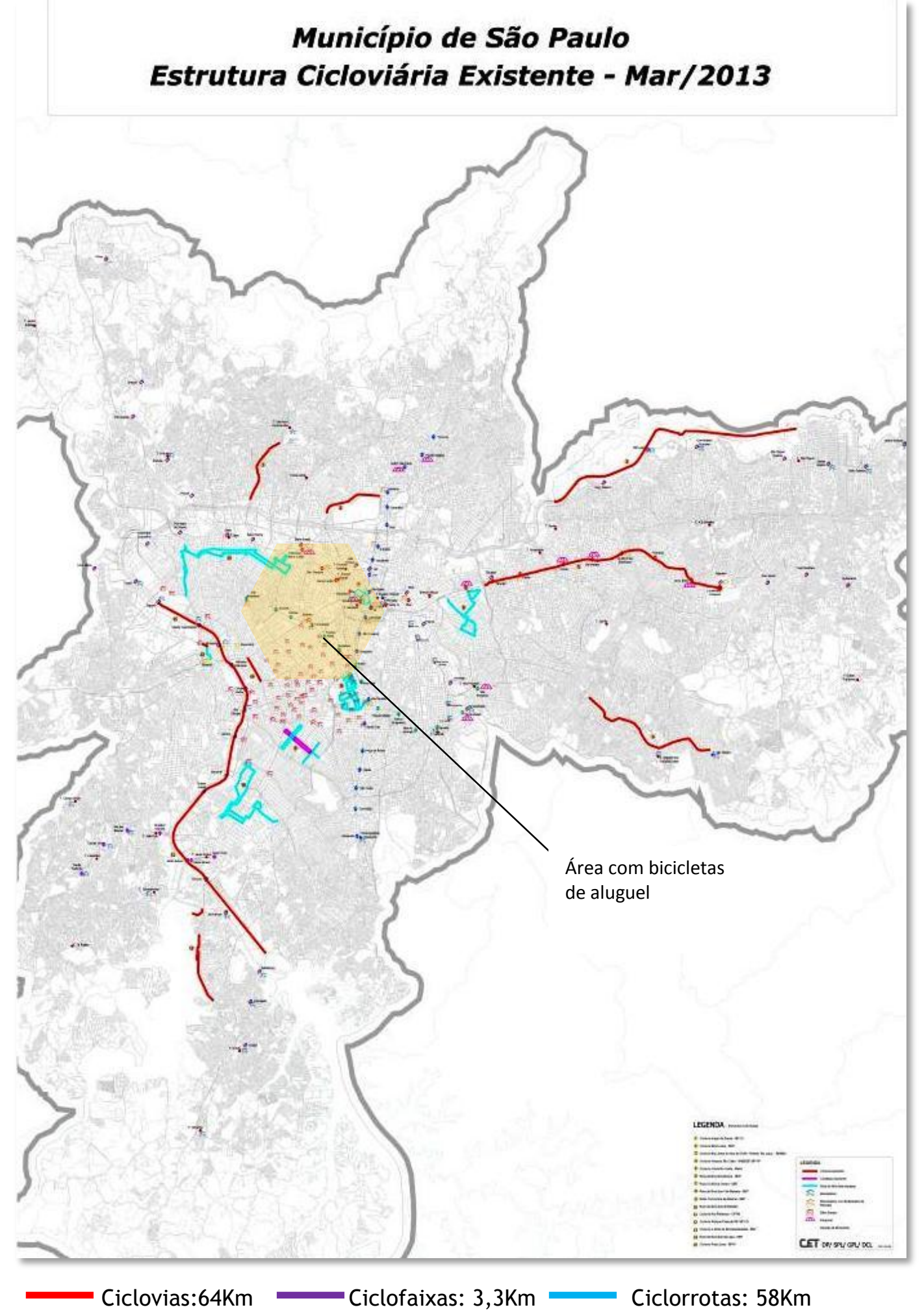

Mapa 11 - Estrutura Cicloviária de Circulação - Março 2013

Fonte: CET - Departamento de Planejamento Cicloviário 
Este fato ocorre porque os percursos ciclísticos implantados tiveram como maior motivação ações políticas apressadas em resposta às pressões da sociedade, aproveitando espaços disponibilizados na cidade, independentemente de como estas infraestruturas cicloviárias poderiam se conectar com a rede viária mais utilizada por ciclistas ou como os usuários poderiam acessá-las.

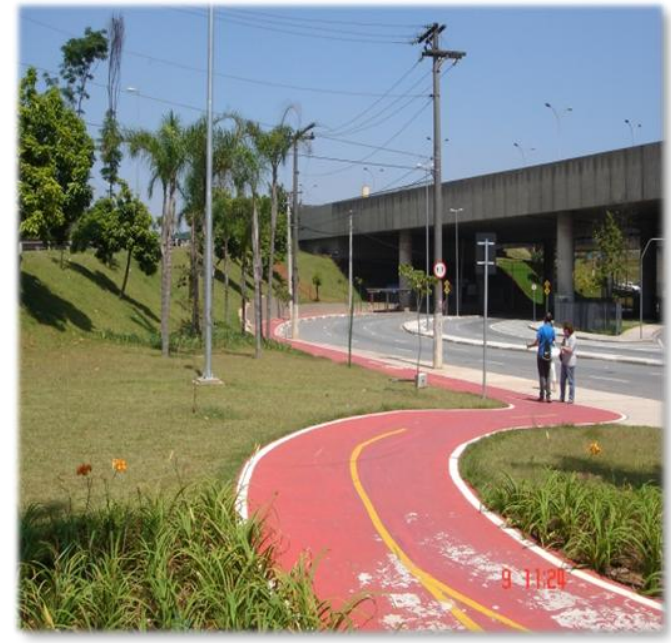

Foto 23 - Ciclovia Caminho Verde (Radial Leste)

Fotos: Arquivo DCL / CET

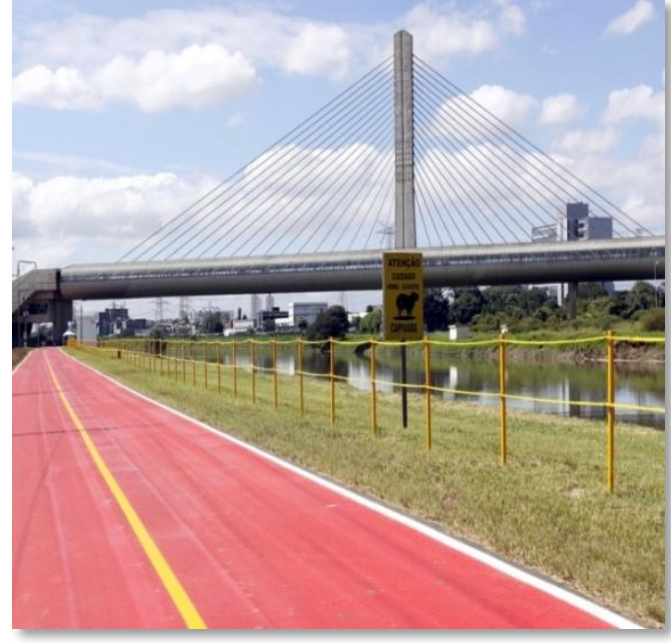

Foto 24 - Ciclovia Rio Pinheiros

Como exemplo pode ser mencionados dois exemplos, um deles constitu' 'ido pela a Ciclovia Caminho Verde, junto ao muro do Metrô, ao longo da Avenida Radial Leste e o outro pela ciclovia do Rio Pinheiros, na margem direita, entre a linha férrea e o leito do rio.

Em ambas as situações a ciclovia corre isolada das atividades lindeiras, com acessibilidade limitada e paralela a eixos de transporte de alta capacidade, com o paradoxo de concorrer com eles ao invés de alimentá-los. Em ambas as ciclovias os percursos apresentam longa extensão: a Ciclovia Caminho Verde tem $12 \mathrm{Km}$ e a Ciclovia do Rio Pinheiros quase $22 \mathrm{Km}$, com sérios problemas de limitação à acessibilidade que dificultam e restringem sua utilização.

Já em outro exemplo, o caso da Ciclovia da Adutora Rio Claro, os problemas resultam numa infraestrutura de circulação com pouca possibilidade de uso por sérios motivos de segurança que serão detalhados no item seguinte.

As demais ciclovias do município até o momento são constituídas por trechos descontínuos, aproveitando oportunidades oferecidas pela disponibilidade de larguras de canteiros centrais como é o caso das avenidas Braz Leme e Faria Lima ou de áreas livres beirando rios e represas: Ciclovia do Parque Tietê junto 
ao Rio Tietê no Parque Ecológico e a Ciclovia Parque do Sol junto à Represa de Guarapiranga. Cabe ressaltar que a ciclovia ao longo da Av. Brigadeiro Faria Lima foi construída em atendimento às determinações da Operação Urbana como Faria Lima.
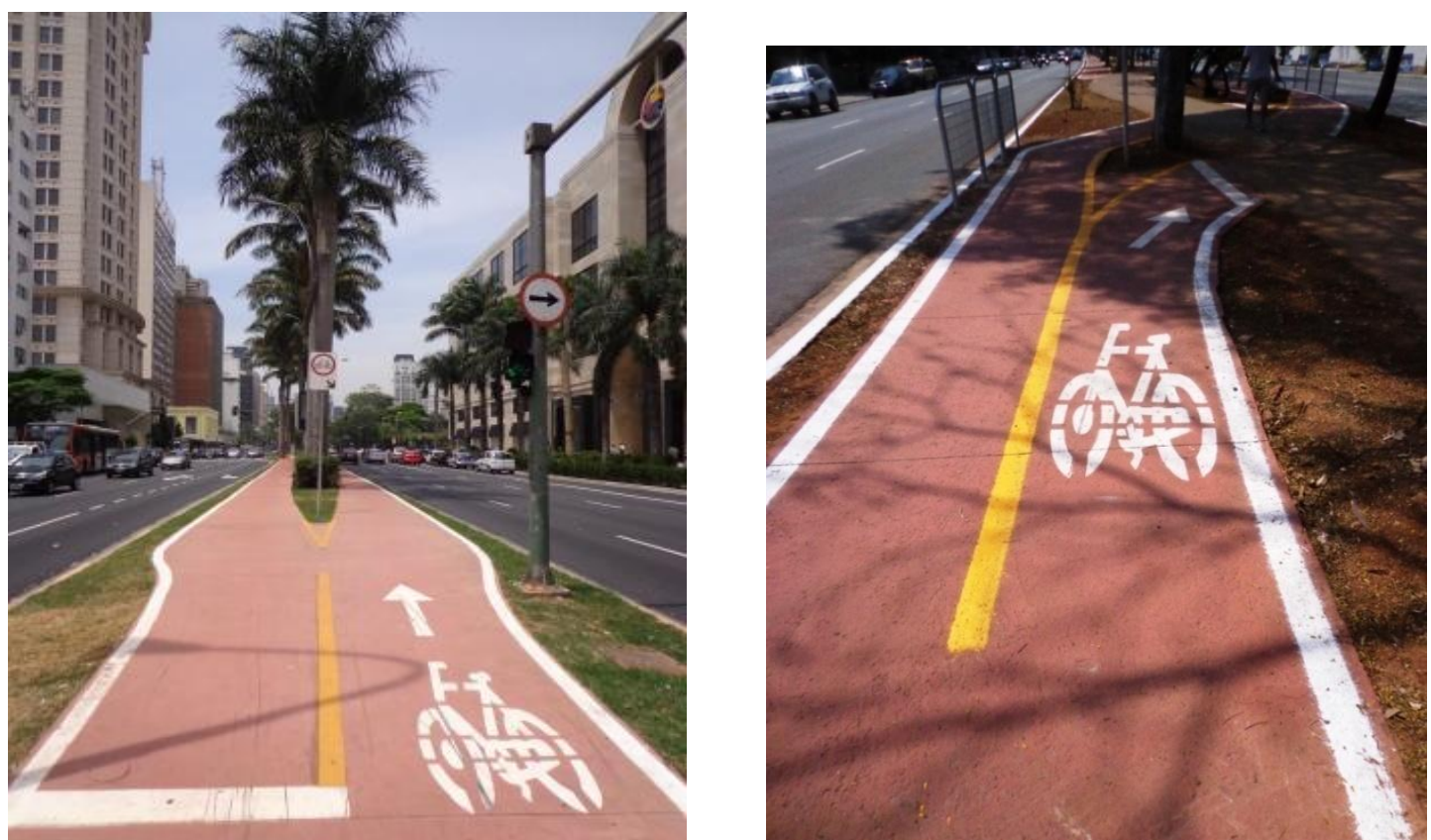

Foto 25 - Ciclovia Faria Lima - operação urbana Foto 26 - Ciclovia Braz Leme -canteiro largo Fotos: Arquivo DCL / CET

Já a pequena rede de ciclofaixas utilitárias com extensão de 3,3 $\mathrm{km}$ abrange duas avenidas em Moema (Rouxinol e Pavão), que interligadas por pequenos trechos de ciclorrotas, apóia viagens internas da área, sem entretanto possibilitar conexão aos sistemas de transporte da região.

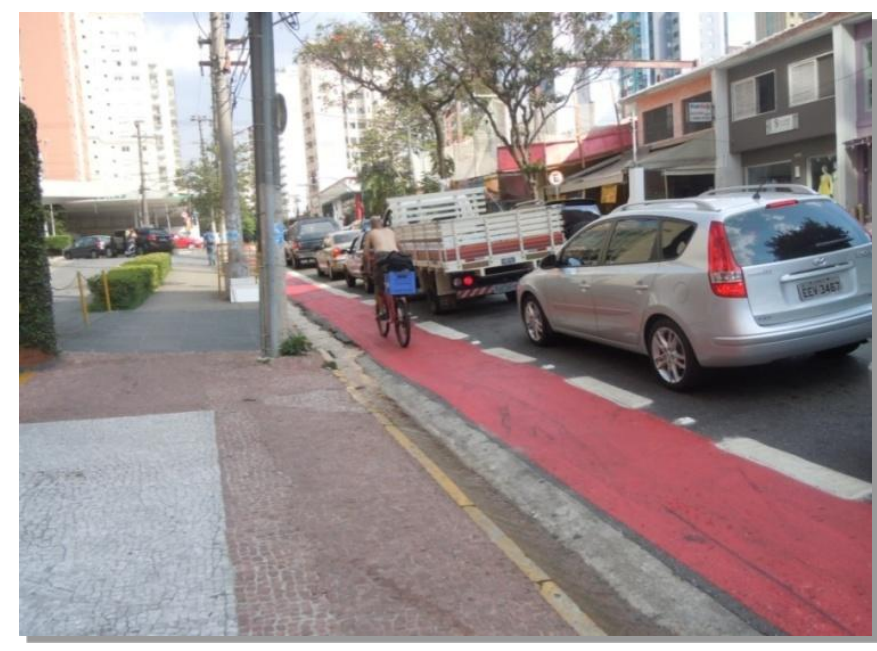

Foto 27 - Ciclofaixa de Moema - Apoio às viagens locais, e bicifrete Foto: Arquivo DCL / CET 
No caso dos $58 \mathrm{~km}$ de ciclorrotas, por se tratarem de infraestrutura cicloviária de circulação onde não há segregação física em relação ao tráfego motorizado, a justificativa das áreas escolhidas para sua implantação foi o atendimento à solicitações políticas e de cicloativistas, servindo também de apoio à circulação de bicicletas dos emergentes sistemas de bicicletas compartilhadas. As ciclorrotas estão atualmente implantadas em vias internas ao Centro Expandido, com menor volume de tráfego. Diferentemente das infraestruturas de circulação com algum nível de segregação em relação ao tráfego motorizado como as ciclovias (segregação física) e ciclofaixas (segregação visual), as ciclorrotas exigem maior desenvoltura e experiência por parte do ciclista e maior controle da velocidade do tráfego motorizado, implicando na redução dos padrões de velocidade anteriormente regulamentados para o viário no qual estão situadas.
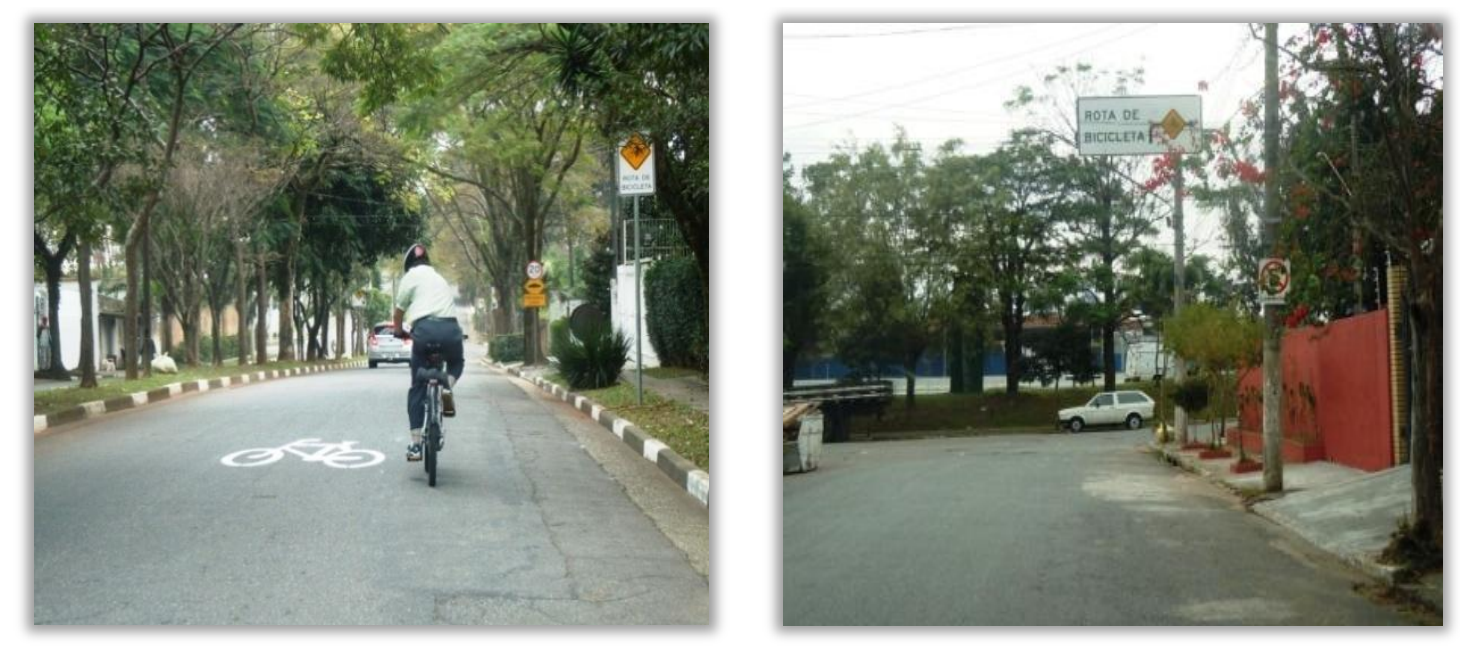

Foto 28 - Exemplos de ciclorrotas - só sinalização, sem segregação espacial para o tráfego Ciclístico

Fotos: Arquivo DCL / CET

Cabe acrescentar que os trajetos onde foram implantadas as ciclorrotas recaem sobre itinerários já consagrados por ciclistas, identificados pelo trabalho elaborado pelo CEBRAP Centro Brasileiro de Planejamento, a partir das informações fornecidas por quem utiliza bicicleta diariamente, mencionado no item 4.3.3. 


\subsection{Ciclovia Adutora Rio Claro ou Ciclovia Parque da Integração Zilda Arns: Um registro de intervenção de má qualidade.}

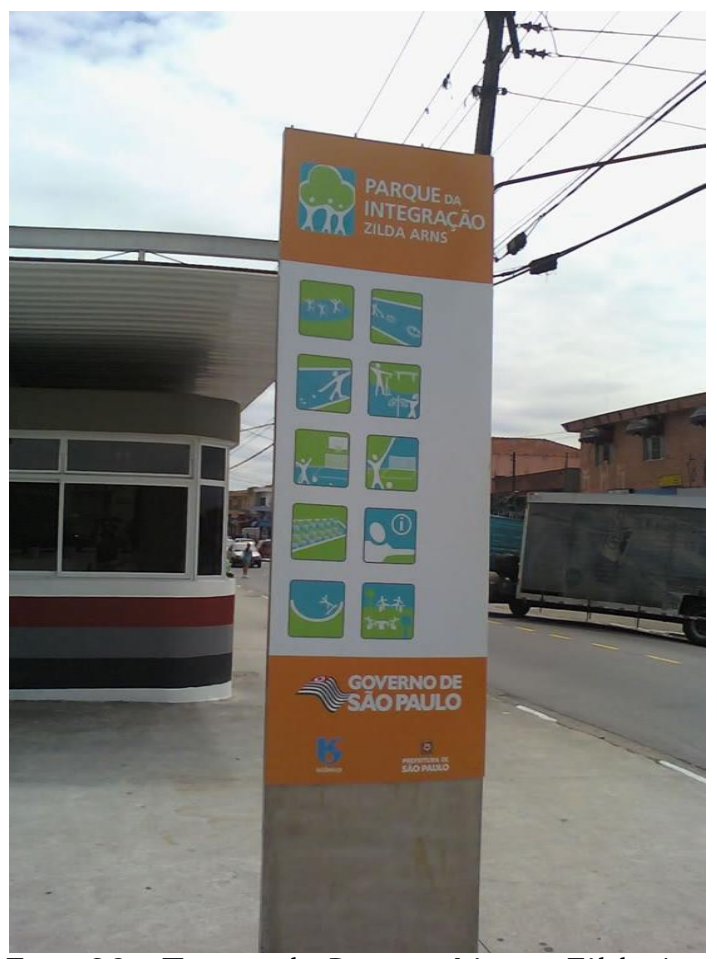

Foto 29 - Totem do Parque Linear Zilda Arns Fonte: foto do site skyscrapercity.com
Situada na região Sudeste do Município de São Paulo, entre os bairros de Vila Prudente e São Mateus se estende uma adutora da Sabesp, denominada Adutora Rio Claro,com $22 \mathrm{Km}$ de extensão. A topografia da área ao longo da adutora possui trechos planos, e outros com grandes desníveis.

A região por ela cortada possui uso do solo residencial de baixa renda com áreas de interesse social. O comércio e os serviços ficam em subcentros dispostos

linearmente ao longo de corredores principais da região como a Av. Sapopemba e Estrada de Vila Ema.

Como toda canalização de grande porte, e por conta de seu afloramento em vários trechos, a faixa da adutora deve permanecer livre de qualquer tipo de edificação. Esta característica somada à falta de zeladoria por parte do órgão responsável por ela, a SABESP, acabou gerando uma convivência conflituosa do equipamento com a população local por gerar um ambiente isolado, perigoso, sujo, com acúmulo de lixo, mato e seus habituais e indesejáveis habitantes e usos (ver Foto 26).

A pressão exercida pela comunidade junto ao poder municipal e junto à SABESP foi respondida com um generoso projeto de recuperação e revitalização urbana, constituído da implantação de um parque linear dotado de pista para ciclistas e para pedestres ao longo do trajeto da adutora, desde a R. Juiz de Fora até a Pça. Felisberto Fernandes, mais conhecida como Largo de São Mateus (ver Foto 27 e Mapa 11). 


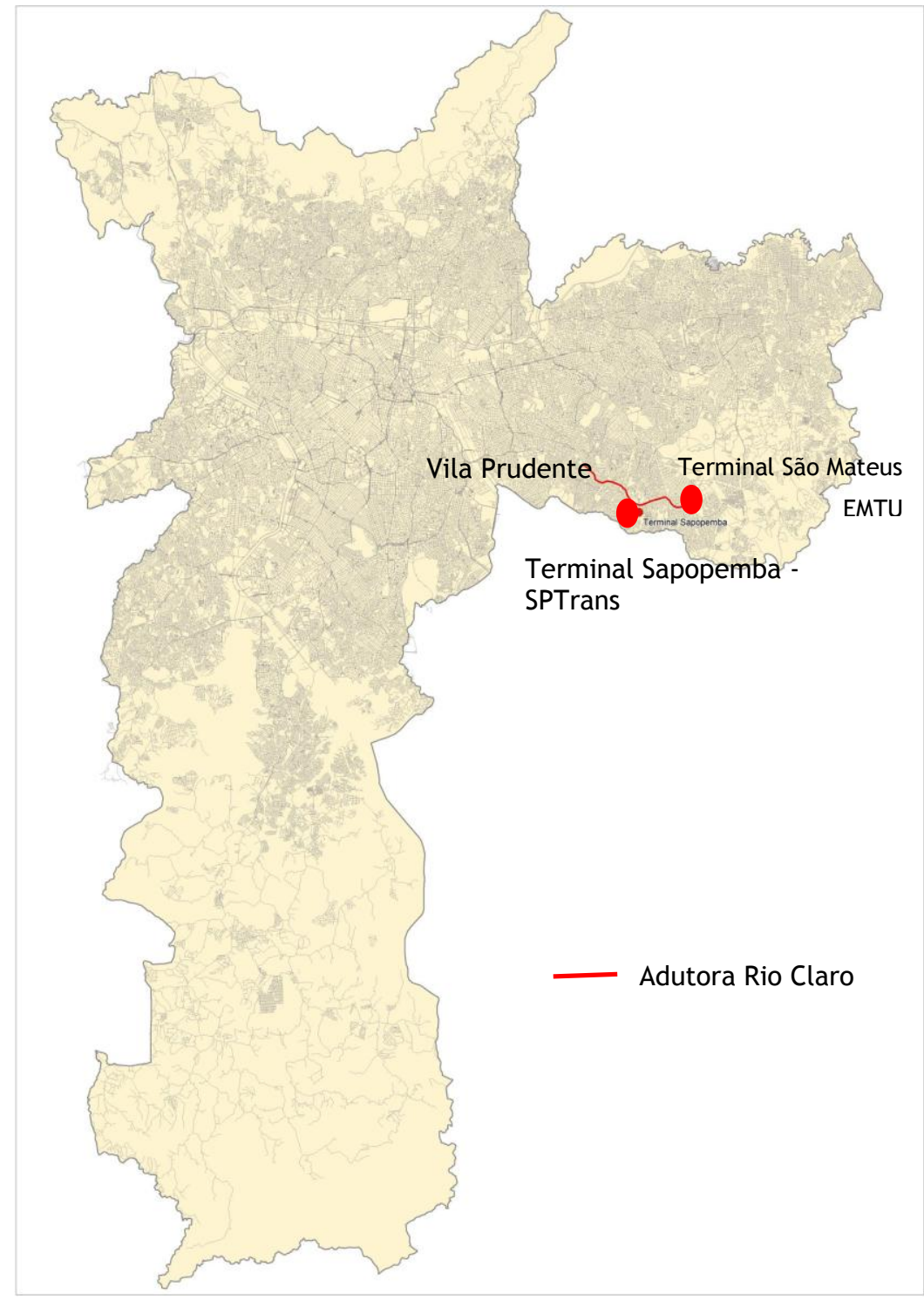

Mapa 12 - Localização geográfica da Adutora Rio Claro Mapa elaborado por Raquel Lourenço Novis

A ambiciosa proposta do parque, com quase $10 \mathrm{Km}$ de extensão e $224 \mathrm{mil} \mathrm{m}^{2}$ de área custou 20 milhões de reais em $2007^{62}$. O terreno no qual foi implantado o parque foi cedido pela empresa sABESP à Prefeitura de São Paulo, que passaria a zelar por ele após a implantação.

O parque foi concebido com toda a infraestrutura de segurança, lazer e esporte, cujo detalhamento encontra-se no ANEXO III.

\footnotetext{
${ }^{62}$ Ciclovias de São Paulo: Parque da Integração Zilda Arns, uma montanha russa de problemas - Revista Bicicleta - Janeiro 2013
} 


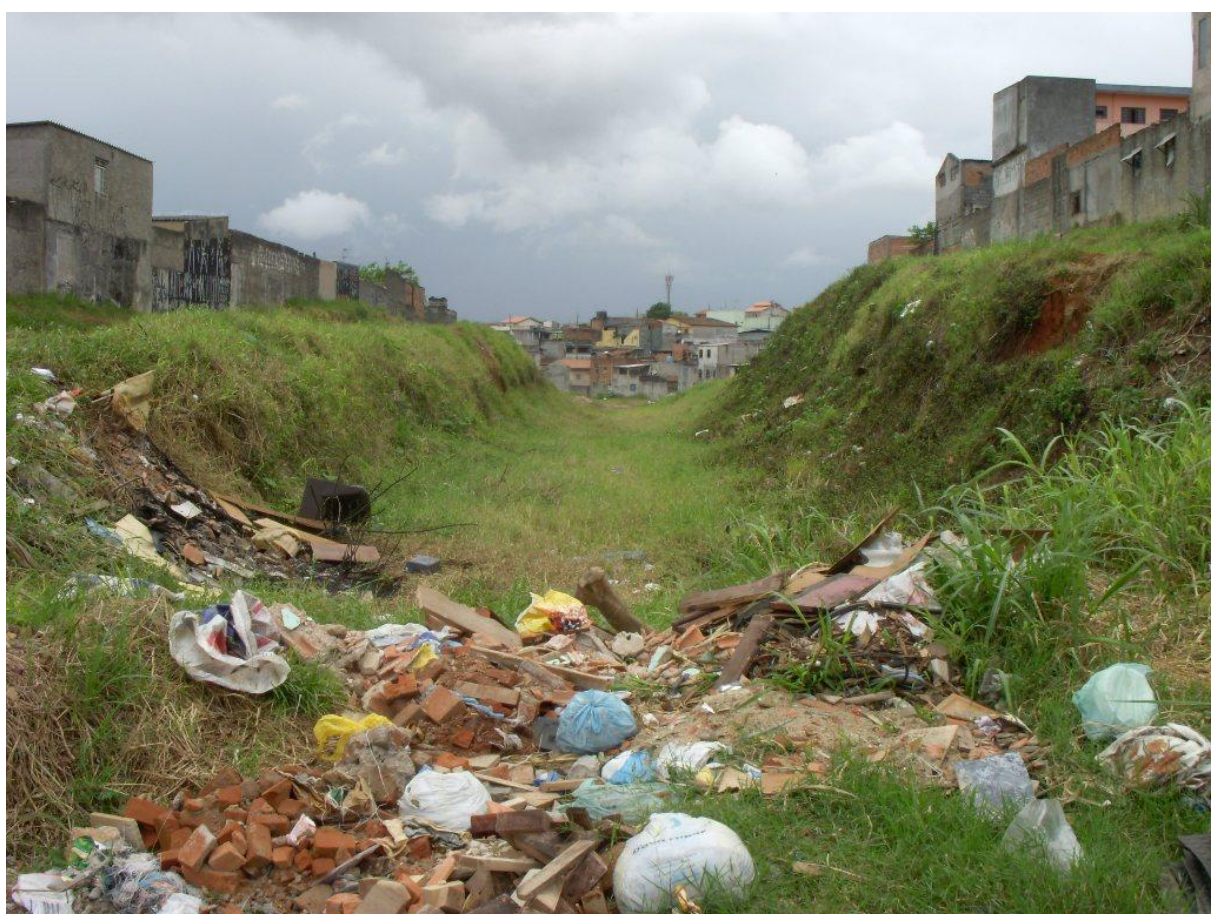

Foto 30 - Trecho da Adutora Rio Claro antes da implantação do parque: sem os cuidados de conservação: com lixo e mato

Foto: Arquivo CET / DCL - 2007

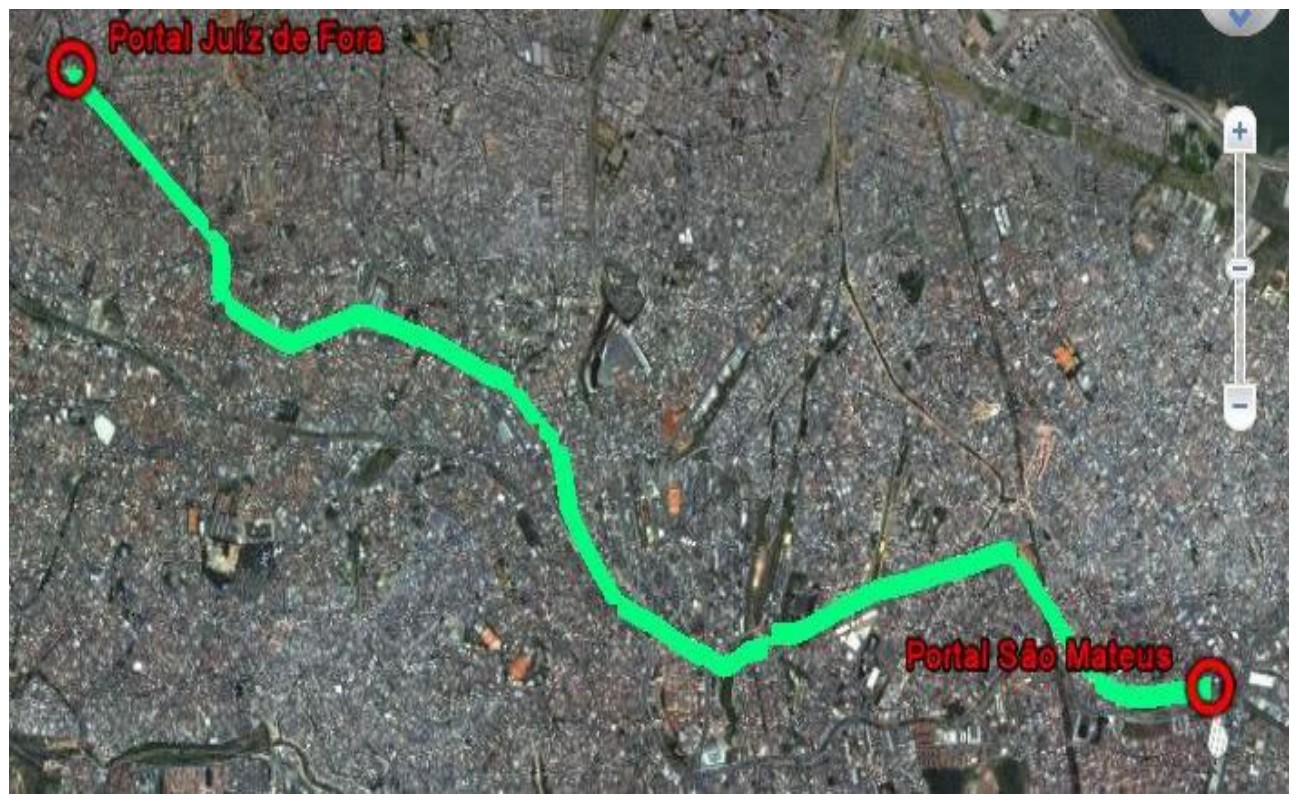

Foto 31 - Trajeto proposto para o parque linear da Sabesp sobre a adutora

Foto: skyscrapercity.com

A elaboração e o detalhamento do projeto do parque foi realizado por convênio da faculdade de arquitetura Escola da Cidade com a SABESP. O diferencial da proposta era a circulação ao longo do trajeto do parque, viabilizada por pistas 
paralelas para pedestres e ciclistas, o que permitiria também que este parque fosse utilizado pela população para o deslocamento diário.

Entretanto a situação da topografia e a inserção da área na malha urbana local estabeleciam dificuldades de difícil transposição com este tipo de proposta. A acidentalidade do terreno impunha declividades abissais (Foto 28) dificultando a circulação a pé e mais ainda a circulação ciclística, desestimulando sua utilização diária.

Outro aspecto problemático que comprometeu a conexão ao longo do parque e a própria segurança dos usuários, foram as freqüentes interrupções da área linear pela malha viária local. Uma boa parte das vias que atravessam o parque, em especial a Av. Sapopemba, apresentava condições de tráfego intenso com presença de muitos ônibus e caminhões. A topografia igualmente não favorecia pois curvas comprometiam a visibilidade nas travessias e exigiam sinalização de trânsito em todas elas, cujos custos não foram previstos pelo projeto da SABESP, ficando portanto, sob responsabilidade da Secretaria Municipal de Transportes.

A falta de planejamento e o descompasso dos cronogramas entre o Governo do Estado e a Prefeitura do Município de São Paulo tiveram como conseqüência vários atrasos na implantação das obras e da sinalização de trânsito, necessária para apoiar travessias de pedestres e ciclistas, deixando seus usuários principalmente crianças, sujeitos ao risco de atropelamentos (Foto 29).

O projeto da ciclovia do Parque da Integração Zilda Arns também não levou em conta a integração com o transporte público uma vez que não foram propostas conexões cicloviárias com o bicicletário existente no Terminal Sapopemba da SPTrans, situado na confluência da Av. Sapopemba com a Av. Arqt ${ }^{\circ}$ Villanova Artigas a poucos metros adiante do local onde ocorre a travessia do parque na avenida, assim como foram ignorados o terminal SPTrans junto ao Lgo. S. Mateus, e além do próprio Terminal São Mateus da EMTU junto à Pça Felisberto Fernandes. 
Foto 32: Ciclovia e pista para pedestres já implantadas confirmam inadequação do local e dificuldade de uso.

Foto: Arquivo CET - 2010
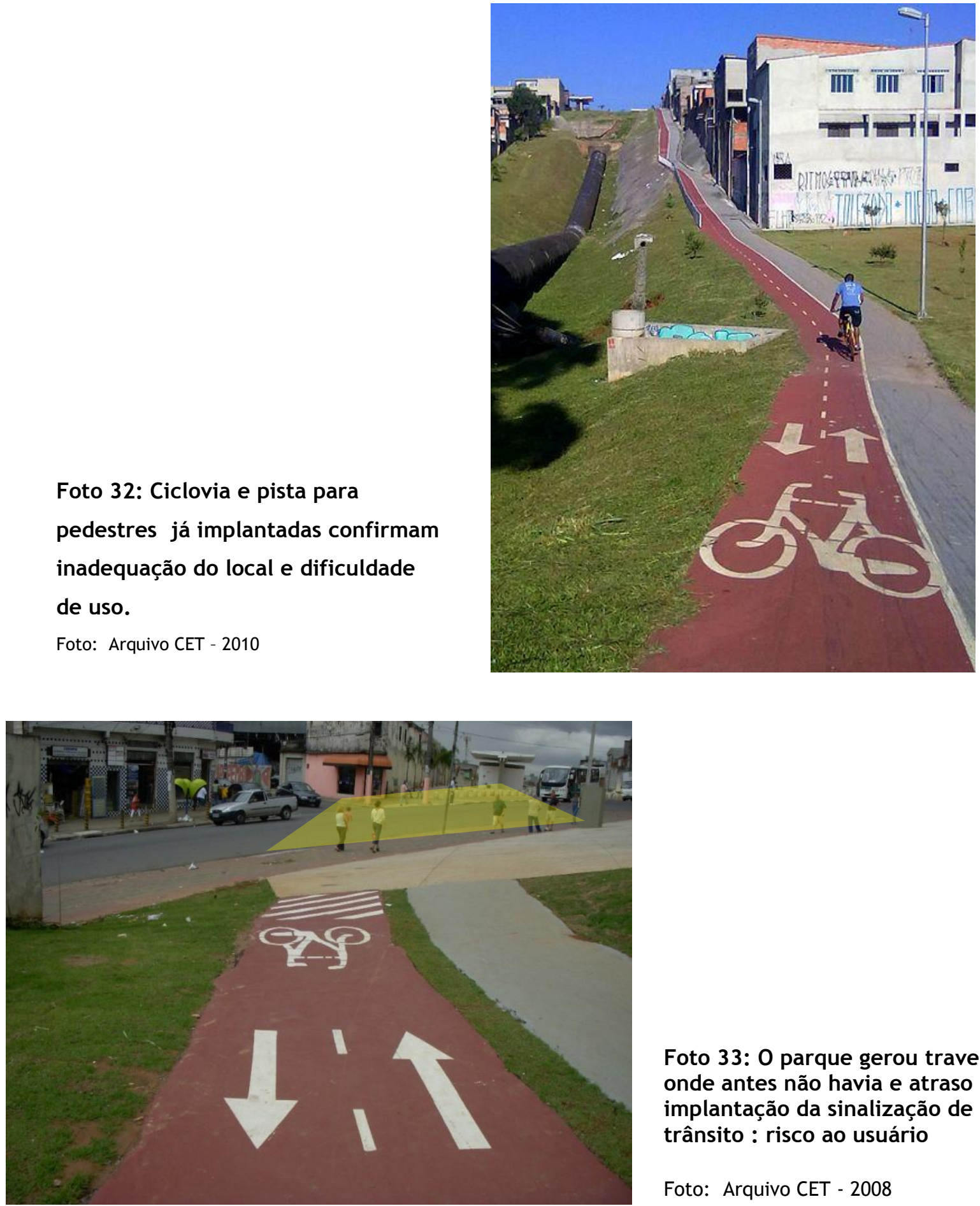

Foto 33: 0 parque gerou travessias onde antes não havia e atraso na implantação da sinalização de trânsito : risco ao usuário

Foto: Arquivo CET - 2008

Outro problema relacionado ao uso cotidiano da ciclovia do parque foi a descontinuidade do percurso na altura da centralidade do Jardim Grimaldi, situado aproximadamente na metade da extensão do parque. Neste local, as pistas para pedestres e ciclistas se encontram interrompidas . 0 prosseguimento do percurso a pé é viabilizado ao longo das calçadas, apesar de 
parcialmente ocupadas pelo mobiliário urbano, ambulantes e pontos terminais de ônibus (Foto 30).

Foto 34Trecho do Jd. Grimaldi, onde a ciclovia e a pista para pedestres desaparecem; Foto: Arquivo CET 2008

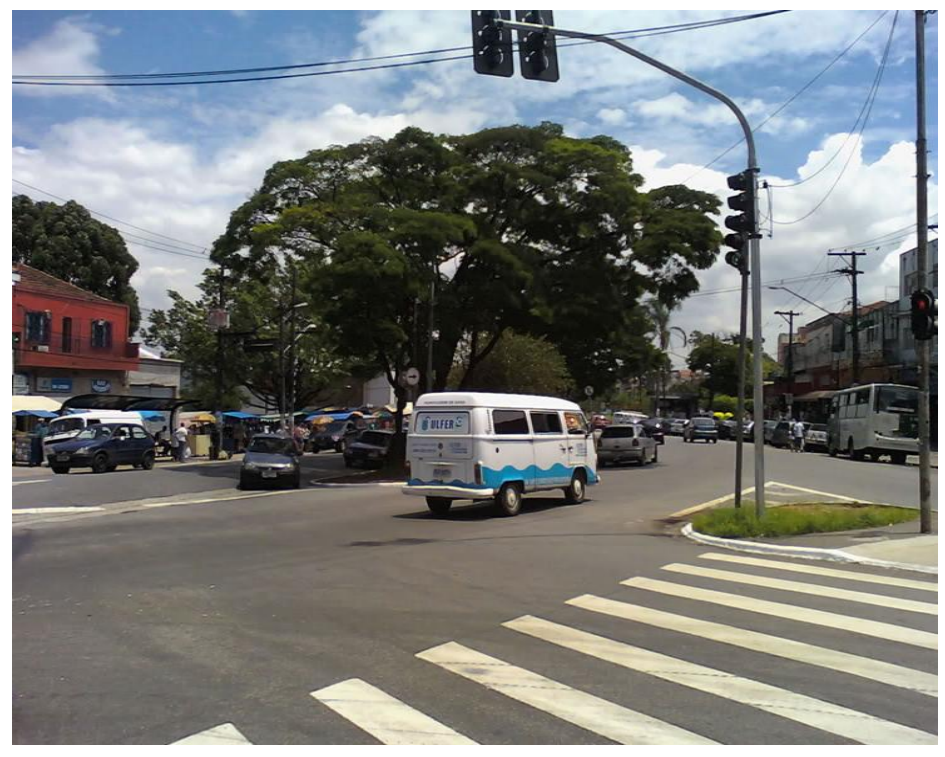

Para o fluxo ciclístico, no entanto, não há alternativa senão disputar o espaço da via, junto ao tráfego motorizado em local potencialmente perigoso pelo volume do tráfego motorizado com muitos ônibus.

Atualmente as condições de conservação deste parque foram descritas em reportagem publicada em uma revista especializada em ciclismo ${ }^{63}$. Nela é denunciado o estado de abandono em que ele se encontra: "descobrimos que boa parte deste projeto está hoje abandonada. Os bicicletários estão em péssimo estado de conservação e mal sinalizados; alguns postos policiais estão abandonados ou nunca funcionaram...

Já a ciclovia é um dos piores problemas, ...É praticamente impossível um ciclista comum fazer todo o trecho pedalando ou trafegá-la sem riscos de sofrer um sério acidente. Há muitos trechos em ladeiras inclinadas onde a bicicleta ultrapassa facilmente os $70 \mathrm{Km} / \mathrm{h}$...Além dos obstáculos como sofás, lixo, entulho e carros estacionados...Certamente um dos maiores problemas que a ciclovia e o Parque Zilda Arns enfrenta é a falta de segurança..Durante a noite é praticamente uma missão suicida pedalar nessa ciclovia, alguns trechos não tem nenhum tipo de iluminação o que encoraja traficantes e criminosos a atuarem

\footnotetext{
${ }^{63}$ Ciclovias de São Paulo: Parque da Integração Zilda Arns, uma montanha russa de problemas - Revista Bicicleta - Janeiro 2013
} 
na região...moradora fala que a falta de policiamento fez com que a ciclovia se tornasse uma rota de fuga de marginais... usam a ciclovia para fugir de moto."

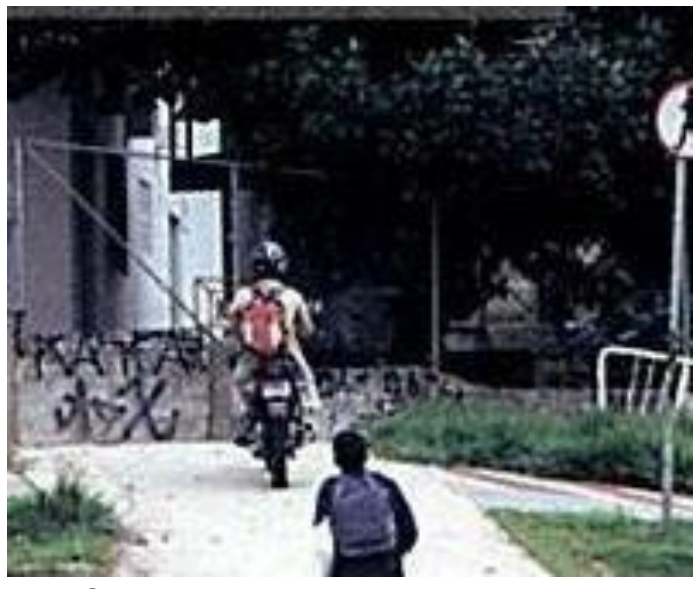

Foto 35 Motos invadindo a ciclofaixa Fotos da Revista Bicicleta - Janeiro 2013

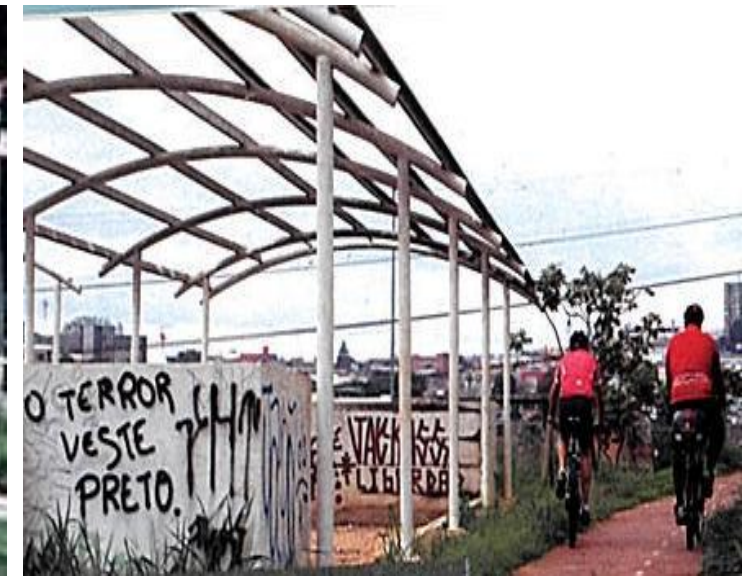

Foto 36 - Edificações abandonadas e pichadas

Questionada a SABESP informou que a responsabilidade do parque instalado sobre a área da sua tubulação é agora de responsabilidade do poder público municipal através da Secretaria do Verde e Meio Ambiente desde 31/10/2012 ${ }^{64}$. Assim o parque construído pela própria SABESP sobre área da adutora, e "presenteado" à prefeitura se encontra atualmente em processo de degradação retomando aos poucos sua situação inicial de geração problemas à região. Entretanto a responsabilidade quanto à solução migraram de uma empresa do governo do estado para a esfera municipal .

Concluindo, o exemplo do Parque Linear Zilda Arns é um caso típico de intervenção voltada à população de baixa renda que não recebeu os cuidados devidos. Apesar de possuir infraestrutura para circulação não motorizada não apresenta condições de oferecer um efetivo suporte às viagens cotidianas da região de São Mateus. Seu projeto não considerou as características topográficas da região assim como a realidade sócio-econômica dos futuros usuários. Não foi precedido de qualquer tipo de plano ou estudo de microacessibilidade que pudesse aferir a demanda de uso ciclístico e explorasse seu potencial de integração aos os sistemas de transportes existentes na área. Trata-se portanto de mais um exemplo de má aplicação de recursos públicos.

\footnotetext{
${ }^{64}$ Ciclovias de São Paulo: Parque da Integração Zilda Arns, uma montanha russa de problemas - Revista Bicicleta - Janeiro 2013
} 


\subsection{Bicicletários e a integração modal aos sistemas de transporte}

A integração modal aos sistemas de transportes existentes em São Paulo é feita atualmente por 61 locais que operam como bicicletários e paraciclos em estações e terminais do Metrô, CPTM e SPTrans. Eles oferecem cerca de 4. 930 vagas para estacionamento de bicicletas. A relação destes bicicletários pode ser visualizada na Tabela 12 Relação de bicicletários e bicicletas de aluguel nas estações e terminais de transporte do Município de São Paulo - Anexo III.

A guarda da bicicleta é um serviço gratuito para os usuários de transporte público de todos os sistemas, tanto sobre trilhos como sobre pneus.

Os bicicletários do Metrô, presentes em 17 estações, incluíam um serviço de bicicletas comunitárias com o objetivo de apoiar viagens de curta distância não se cobrando a primeira meia hora de utilização. Este serviço de guarda conjunta ao empréstimo de bicicletas foi iniciado com a o apoio econômico da iniciativa privada, através da Porto Seguro e o apoio administrativo de uma ONG de cicloativismo, a Parada Vital, encarregada da administração dos locais, recrutando para os postos de trabalho, jovens oriundos de programas sociais. Atualmente este serviço encontra-se temporariamente indisponível por problemas orçamentários, conforme informado pela mídia ${ }^{65}$ : "Segundo o Metrô, o instituto, mantido basicamente por publicidade e apoios insititucionais, passa por dificuldades orçamentárias e não está conseguindo manter o pagamento dos funcionários. De acordo com este mesmo artigo, "o serviço de guarda de bicicletas está disponível somente nas estações Anhangabaú, Palmeiras-Barra Funda, Guilhermina-Esperança e Butantã."

Estes locais foram mantidos por uma decisão do Metrô, pela importância para as regiões que estão e a expressiva movimentação de uso diário.

Todos bicicletários das estações da CPTM, em especial as Estações do Jardim Helena e Itaim Paulista são muito procurados, ficando lotado nas primeiras horas da manhã, de acordo com informações obtidas in loco junto aos funcionários.

\footnotetext{
${ }^{65}$ Folha de São Paulo "Só 4 de 17 bicicletários ainda funcionam nas estações de metrô" 15/01/2013
} 
Eles informaram também que muitos usuários que não conseguem encontrar vagas e acabam deixando suas bicicletas em residências próximas à estação, que passaram a explorar serviços como bicicletários informais. Entretanto cobram uma taxa pequena (cerca de $\mathrm{R} \$ 10,00$ de mensalidade) ${ }^{66}$, ao contrário da guarda nos bicicletários das estações, onde o serviço é gratuito.

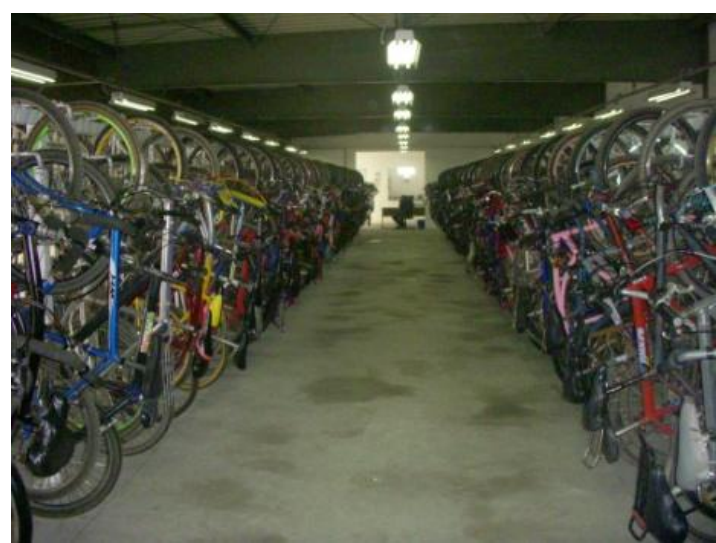

Foto 37 Interior do bicicletário Jd. Helena Fotos: Arquivo DCL / CET

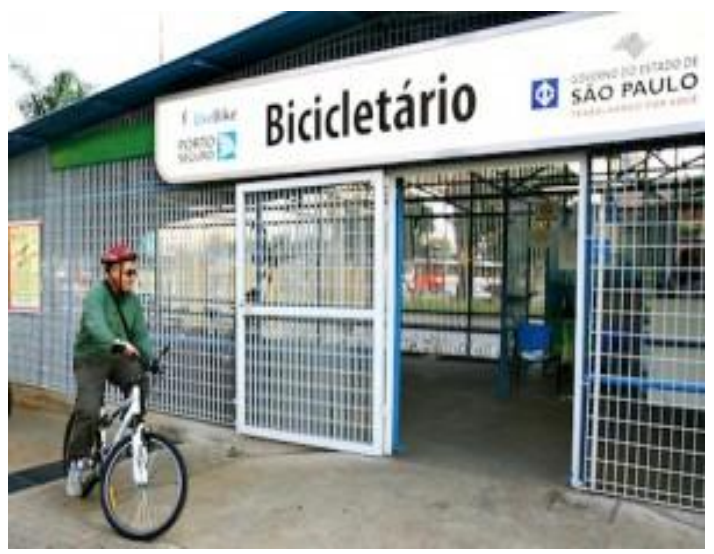

Foto 39 Fachada do bicicletário Metrô Carrão 137 vagas (atualmente fechado)

Fotos: Site do Metrô

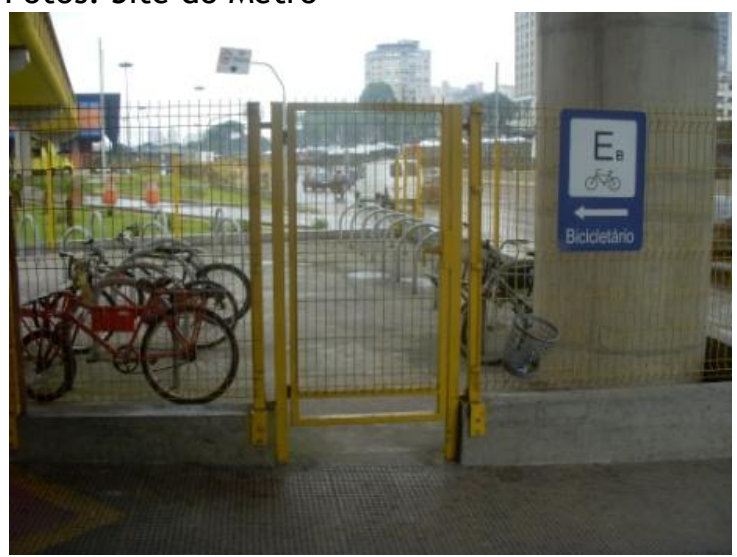

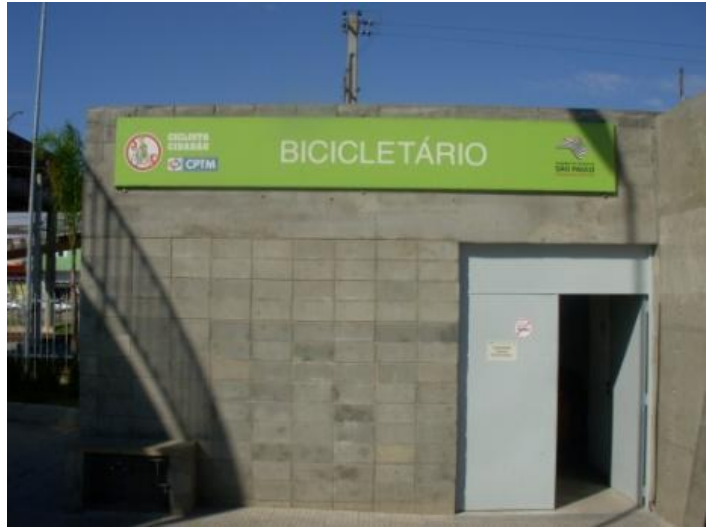

Foto 38 Fachada do bicicletário Jd. Helena

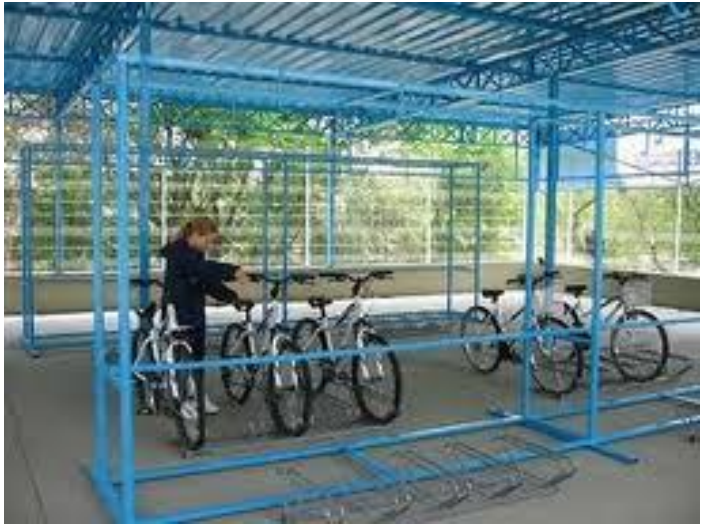

Foto 40 Interior do mesmo bicicletário Com

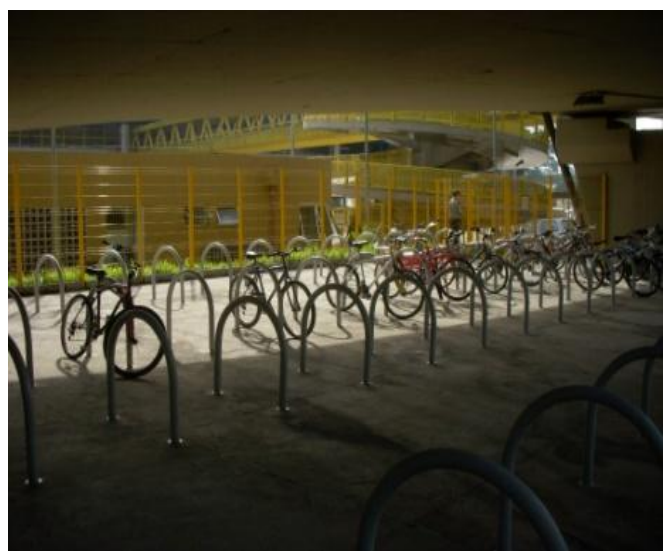

\footnotetext{
${ }^{66}$ Informação obtida no local pela autora em abril de 2013
} 
Foto 41 Fachada do bicicletário da SPTrans Fotos: Arquivo DCL / CET
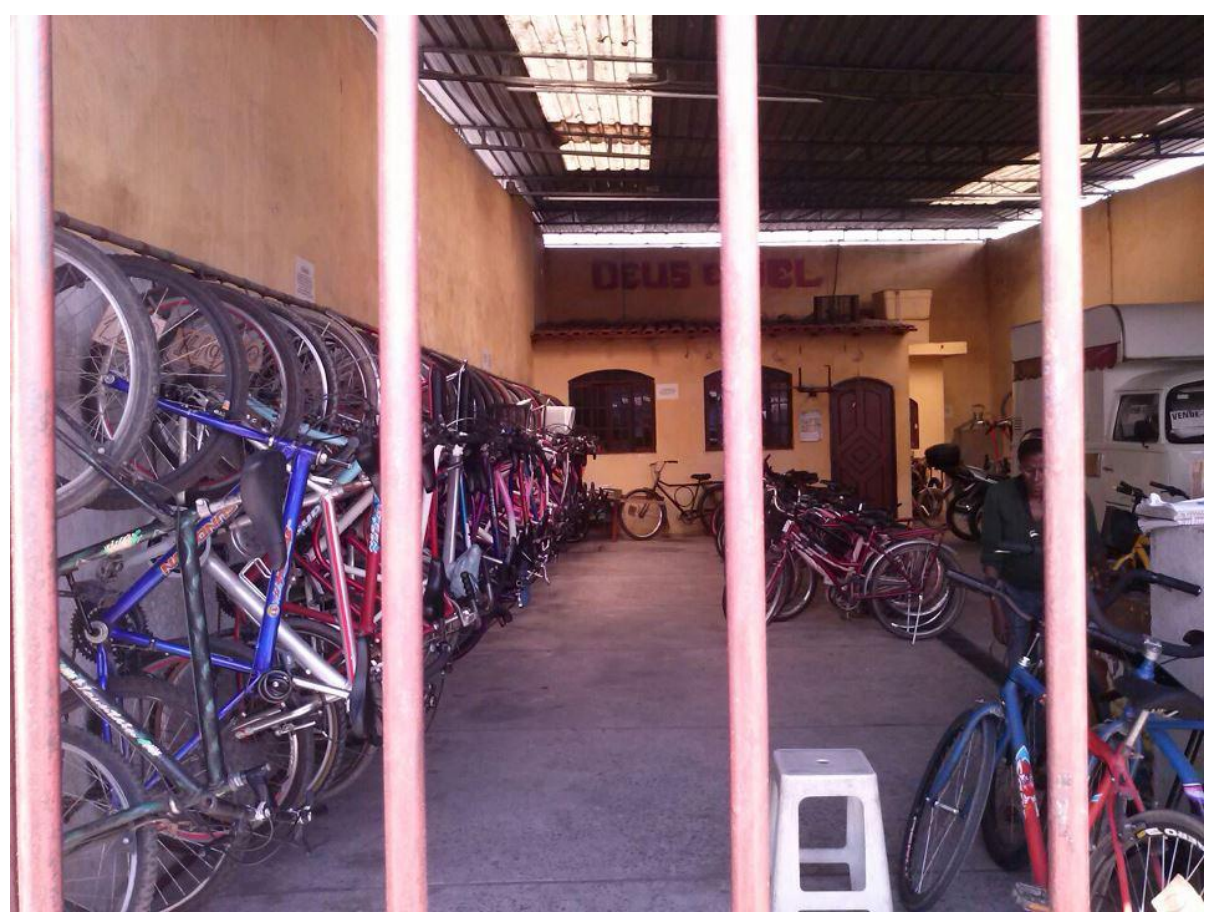

Foto 43 - Bicicletário informal situado próximo ao bicicletário da CPTM de Itaim Paulista Foto: Arquivo da autora

Além destas vagas, é permitido o acesso de bicicletas em vagões específicos da rede do Metrô e da CPTM, em número máximo de quatro bicicletas por vagão diariamente após às 20:30 hs no metrô, sábados após às 14:00 hs, domingos e feriados o dia todo, tanto no metrô como nos trens da CPTM ${ }^{67}$.

Os bicicletários da SPTrans situados em paradas e terminais apesar de também serem gratuitos, tem índices de utilização menores do que os bicicletários do Metrô e da CPTM. Um dos motivos do baixo índice de utilização pode ser atribuído ao sistema de zeladoria destes locais, uma vez que a maioria são semi abertos, sem a presença de funcionários responsáveis pelo controle de entrada e retirada de bicicletas, facilitando o roubo e vandalismo. De acordo com a mídia: 68 "Atualmente, apenas três dos 28 terminais municipais possuem locais para guardar bicicletas. Outros quatro devem receber bicciletários nos próximos meses."

\footnotetext{
${ }^{67}$ Programa Ciclista Cidadão da CPTM - ver folder no Anexo III

68 Jornal Metro - Novos terminais terão bicicletários - 09/04/2013
} 


\subsection{Bicicletas públicas: bike sharing ou bicicletas compartilhadas}

Atualmente o sistema de bicicletas compartilhadas ou bicicletas públicas do município de São Paulo tem, em princípio, os mesmos objetivos dos sistemas operantes em algumas cidades do mundo como Paris, Barcelona ou Montreal. Viabilizado através de parceria com a iniciativa privada ou mantido somente pelas prefeituras, é um sistema que disponibiliza bicicletas dispostas em “módulos de retirada" ou "estações" situadas próximas à estações de metrô, escolas, shoppings, ruas comerciais e outros pontos estratégicos para viabilizar a integração modal ou a interligação através de viagens de bicicleta.

O uso do sistema se dá mediante cadastramento prévio, com a utilização de cartão de crédito. Para estimular a rotatividade que é o principal objetivo do serviço, a primeira meia hora é gratuita, sendo cobrado o tempo que exceda a este período.

O município de São Paulo já conta com pontos de bicicletas comunitárias desde 2008, iniciado em algumas estações do Metrô, já abordado no item 4.3.3.

A partir de maio de 2012 foi introduzido o sistema Bikesampa em módulos com 10 bicicletas instalados no sistema viário, em sua maioria situadas ao longo do meio fio, no alinhamento do estacionamento. Mais recentemente foi inaugurado sistema de bicicletas públicas Ciclosampa.

Os custos do sistema tem sido suportados através de parceria com a iniciativa privada, com os consequentes riscos de indisponibilidade parcial ou término, no caso de desistência do patrocínio, como já ocorrido com este tipo de serviço nas estações do Metrô.

A seguir serão apresentados os serviços de bicicletas comunitárias existentes em São Paulo.

\subsubsection{Bicicletas do Metrô}

As primeiras bicicletas comunitárias foram instaladas junto com os bicicletários que o Metrô implantou em algumas estações das linhas Verde, Vermelha e Azul a partir de 2008. O empréstimo era gratuito na primeira meia hora e nas horas subsequentes cobrava-se a tarifa de R\$ 2,00 a hora, através de débito em cartão 
de crédito. Este sistema, patrocinado inicialmente pela empresa Porto Seguro e depois SABESP, funcionava no interior dos bicicletários e era administrado pela ONG Parada Vital. Esta ONG também se responsabilizava pela zeladoria da guarda de bicicletas particulares gratuitamente. Os funcionários recrutados para trabalhar neste projeto eram oriundos de programas sociais e recebiam treinamento específico para operarem o setor administrativo e de manutenção das bicicleta de aluguel. Atualmente este serviço encontra-se indisponível e os bicicletários fechados, por problemas financeiros da ONG, que alega não conseguir mais patrocínio.

Cabe lembrar que este serviço foi implantado a partir de uma iniciativa do próprio Metrô, como um projeto isolado, não servido ou articulado a qualquer rede cicloviária, a exceção dos bicicletários das estações Corínthians Itaquera, Guilhermina Esperança e Carrão, apoiados pela Ciclovia Caminho Verde, ao longo da Avenida Radial Leste. Em função da exigência de cartão de crédito para o cadastramento ao sistema das bicicletas compartilhadas, seu uso ficou restrito à parcela da população de baixa renda, que utilizada somente o bicicletário para a guarda do veículo.

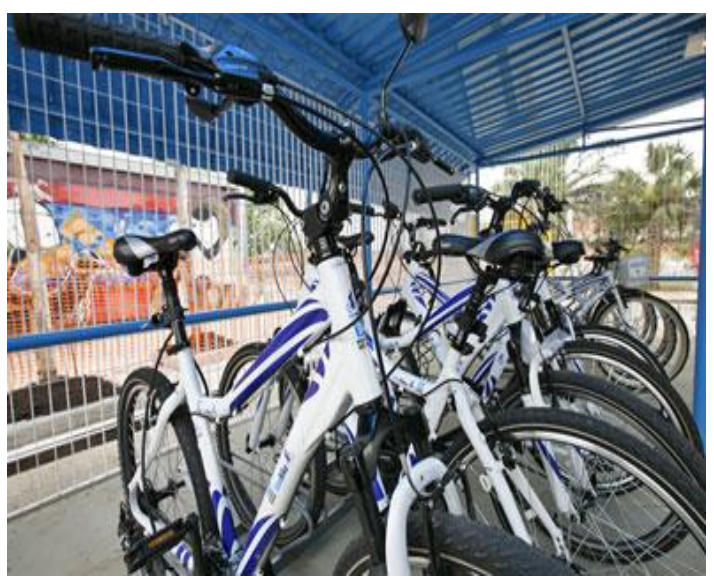

Foto 44 Bicicletas patrocinadas pela Porto Seguro Foto 45 Sistema de controle Fotos dos portais $\mathrm{G} 1$ (Globo) e Terra

\subsubsection{Sistema Bikesampa}

O sistema Bikesampa de bicicletas comunitárias, semelhante aos modelos já utilizados nas cidades européias e americanas, é resultado de uma parceria entre o poder público e a iniciativa privada, no caso o Banco Itaú (ver item 4.3.3). 
Com o objetivo de dotar a cidade de serviço bicicletas para serem utilizadas nos percursos entre o transporte público e o destino final da viagem, este sistema foi iniciado nos bairros de contorno do Parque do Ibirapuera, com previsão de mil bicicletas dispostas em suportes próprios denominados estações, com dez bicicletas cada uma.

Os locais escolhidos para estas estações foram pontos estratégicos com potencial de interesse ciclístico tais como estações de metrô, corredores de ônibus, escolas, faculdades, comércio, equipamentos culturais e parques. Pequenos percursos formam a ligação entre as estações sendo permitidas retiradas e devoluções em qualquer um dos pontos instalados em vias dos bairros, que podem ser visualizados no Mapa 12 .

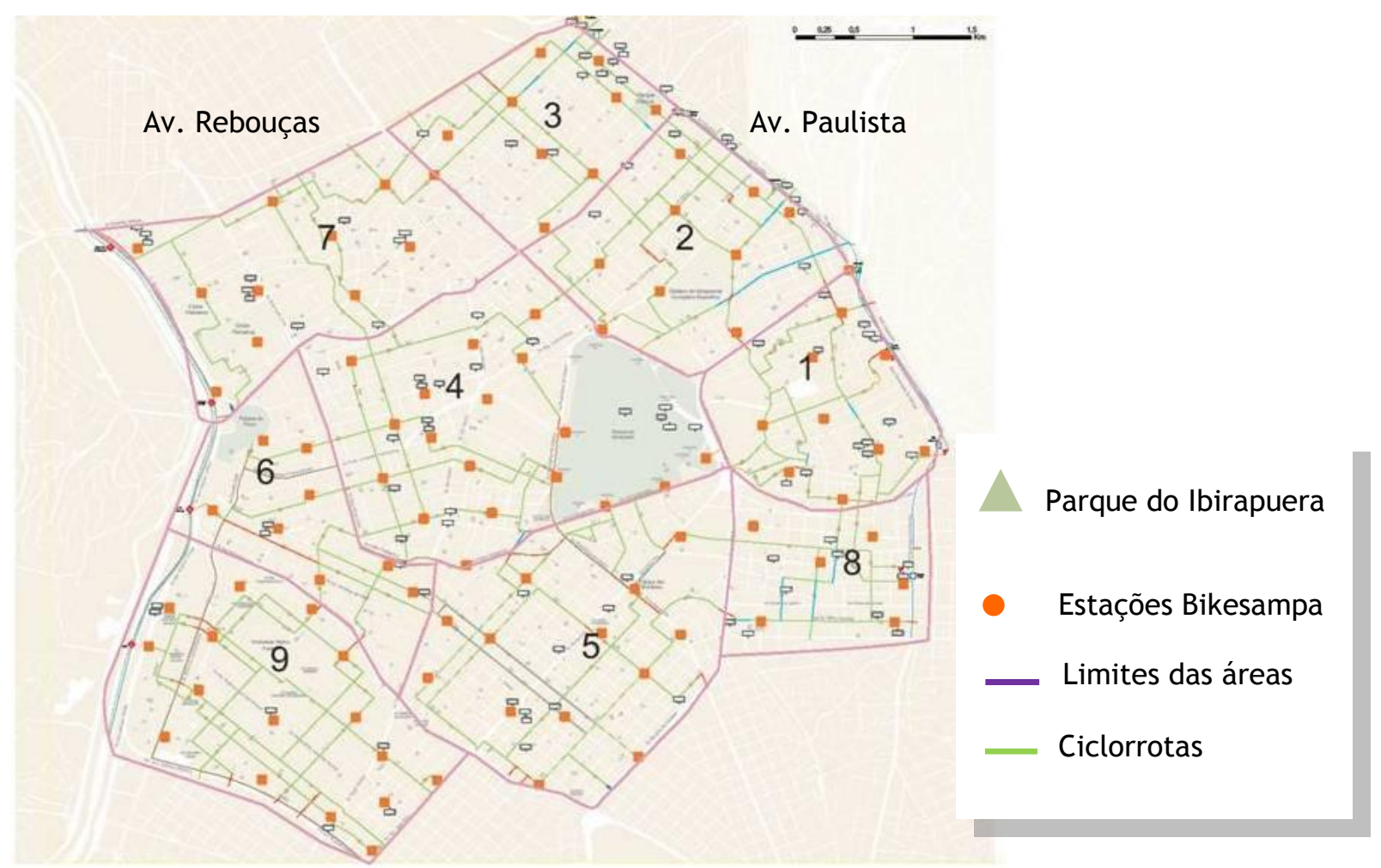

Mapa 13 Nove áreas das 100 primeiras estações do Programa Bikesampa - Total: mil bicicletas

Fonte: Portal Bikesampa / Ciclorrotas CEBRAP

Assim concomitantemente ao atendimento à legislação municipal de paisagem urbana, (Lei da Cidade Limpa), este tipo de infraestrutura cicloviária é resultado de uma estratégia de marketing de sensibilização para a causa ambiental e à sustentabilidade, através da oferta de um tipo de mobilidade ágil e moderna. 
Para utilizar este serviço o usuário precisa ter smartphone (telefone celular com internet), acessar um site específico, informar os dados do cartão de crédito e se cadastrar.

Neste primeiro contato é descontado um depósito de $\mathrm{R} \$ 10,00$ para cobrir eventuais multas quando o uso da bicicleta ultrapassa o período gratuito inicial de trinta minutos.

Entre dois usos de período gratuito é necessário haver um intervalo mínimo de quinze minutos para não haver cobrança e quando o tempo de gratuidade for ultrapassado, é cobrado o valor de $\mathrm{R} \$ 5,00$ a cada trinta minutos a mais de uso. Atualmente este serviço possui mais de 1.200 usuários cadastrados e índices de utilização que variam de acordo com a localização do ponto. Já foram realizadas algumas pesquisas sobre o sistema: Uma avaliação dos usuários do empréstimo de bicicleta feita pela Prefeitura mostra que 70\% das viagens são realizadas em dias úteis e duram até 15 minutos. Além disso, 60\% das bicicletas são utilizadas nos horários de pico. Quase metade dos ciclistas (45\%) também são usuários do transporte público ${ }^{69}$.
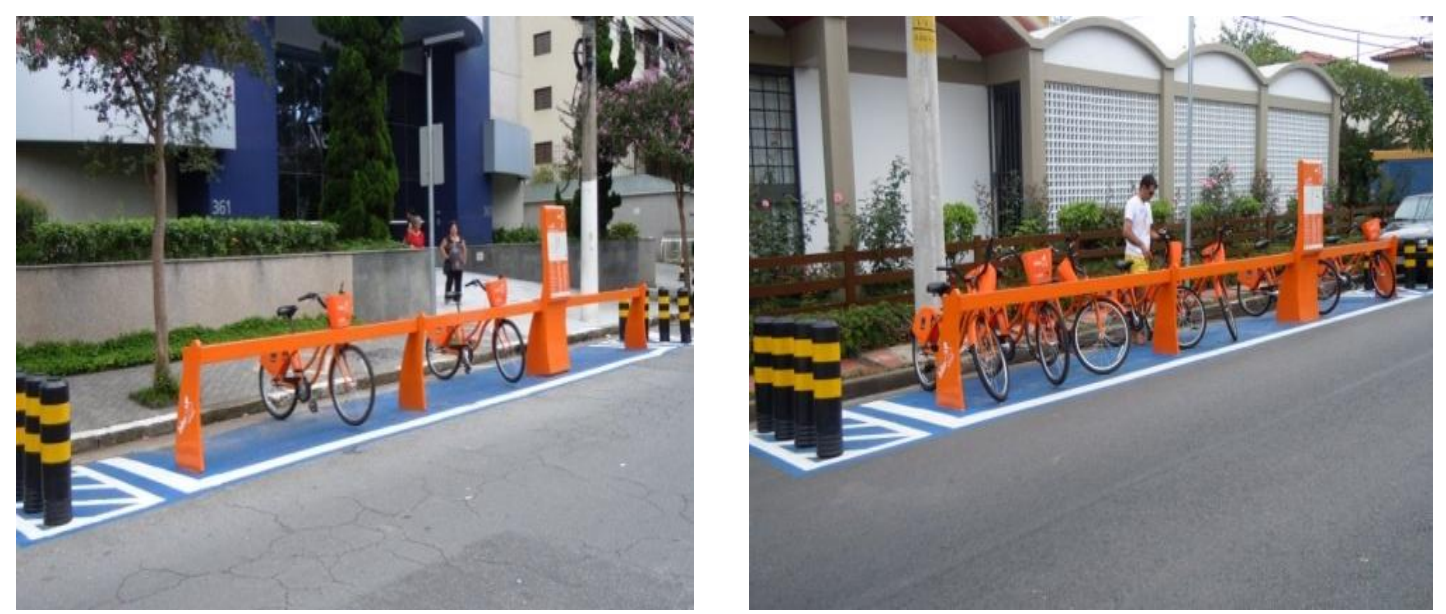

Foto 46 e Foto 47 - Exemplos de estações do Bikesampa em frente a prédios institucionais Fotos: Arquivo DCL / CET

\subsubsection{Sistema Ciclosampa}

Outro sistema de bicicleta pública recém inaugurado, o Ciclosampa iniciou com cinco estações de bicicletas compartilhadas na região da Av. Paulista ${ }^{70 "} A$

\footnotetext{
${ }^{69}$ Folha de SP "SP testa uso do Bilhete Único no empréstimo de bicicletas" - 02/05/2013

${ }^{70}$ Portal IG Economia - "Bradesco copia Itau e lança aluguel de bicicletas em SP - 15/12/2013
} 
empresa lança a partir de amanhã (15) seu patrocínio ao serviço de aluguel de bicicletas Ciclo Sampa, em parceria com a prefeitura de São Paulo. O projeto terá, a princípio, cinco estações e 43 bikes nos arredores da Avenida Paulista, na capital paulista."

Como esta região já conta com as estações do sistema Bikesampa, nada acrescenta de novo como serviço a este tipo de infraestrutura.
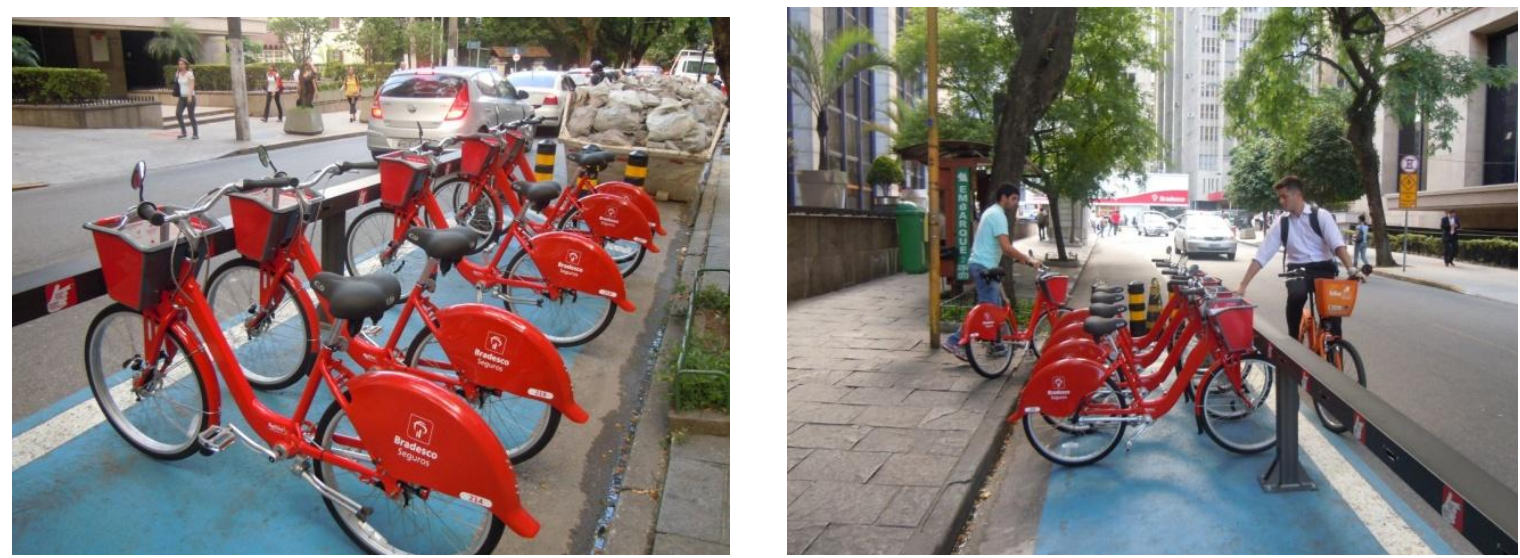

Foto 48 e Foto 49 - Estações do Sistema Ciclosampa de bicicletas públicas.

Fotos: Arquivo DCL / CET 


\subsection{Ciclofaixas de Lazer - uma invenção paulistana}

Apesar de não ser um tipo de infraestrutura cicloviária definitiva para uso cotidiano, é indiscutível a importância das Ciclofaixas de Lazer como mecanismo político para a criação de uma mentalidade ciclística na cidade. Os $120 \mathrm{Km}$ de faixas reservadas nas principais ruas e avenidas para uso exclusivo por ciclistas das 07:00 às $16: 00$ horas aos domingos e feriados, chama a atenção da população para a possibilidade de utilização da bicicleta no dia a dia e cria a cultura ciclística pela oportunidade do exercício de direitos e deveres previstos por lei para todos os usuários da via.

Cabe lembrar que há legislação municipal instituindo ciclofaixas para lazer aos domingos desde o início dos anos noventa através do Decreto Municipal 29.839 de 19 de junho de 1991 que “ INSTITUI FAIXAS EXCLUSIVAS PARA 0 TRAFEGO DE BICICLETAS-CICLOVIAS, E DA OUTRAS PROVIDENCIAS”.

$\mathrm{Na}$ época ainda não havia o apelo ambiental atual e a criação destas ciclofaixas tinha como intuito somente o lazer e a atividade física. Quase vinte anos depois a idéia foi retomada com a ampliação de seus objetivos iniciais, contribuindo para isto a já vigente política municipal de utilização cotidiana da bicicleta como transporte, além do Código de Trânsito Brasileiro de 1997 que assumia a bicicleta na categoria de veículo não motorizado (ver item 4.1.1).

Entretanto o papel da Ciclofaixa de Lazer acabou se tornando muito mais amplo do que o inicialmente previsto: de mecanismo para incentivo ao uso da bicicleta a Ciclofaixa de Lazer passou a ser vista pela população como oportunidade para exploração e desfrute da própria cidade, seus parques e espaços públicos emblemáticos de forma mais livre e aproximada de convivência, fora de seus automóveis e de suas zonas de conforto. A permissão da entrada de bicicletas no metrô e trens da CPTM contribuíram para o facilitar o acesso, uma vez que há estações ao longo dos $120 \mathrm{Km}$ existentes.

Outra função importante da Ciclofaixa de Lazer é instrumentalizar o entendimento legal da bicicleta como veículo, informando aos atuais e futuros usuários os procedimentos previstos pela lei como condutores de no trânsito, lembrando que não há obrigatoriedade de um processo formal de capacitação do condutor da bicicleta, como é exigido para os condutores dos demais veículos. 
Para as crianças, colabora como oportunidade para a prática de educação de trânsito e cidadania de forma geral.

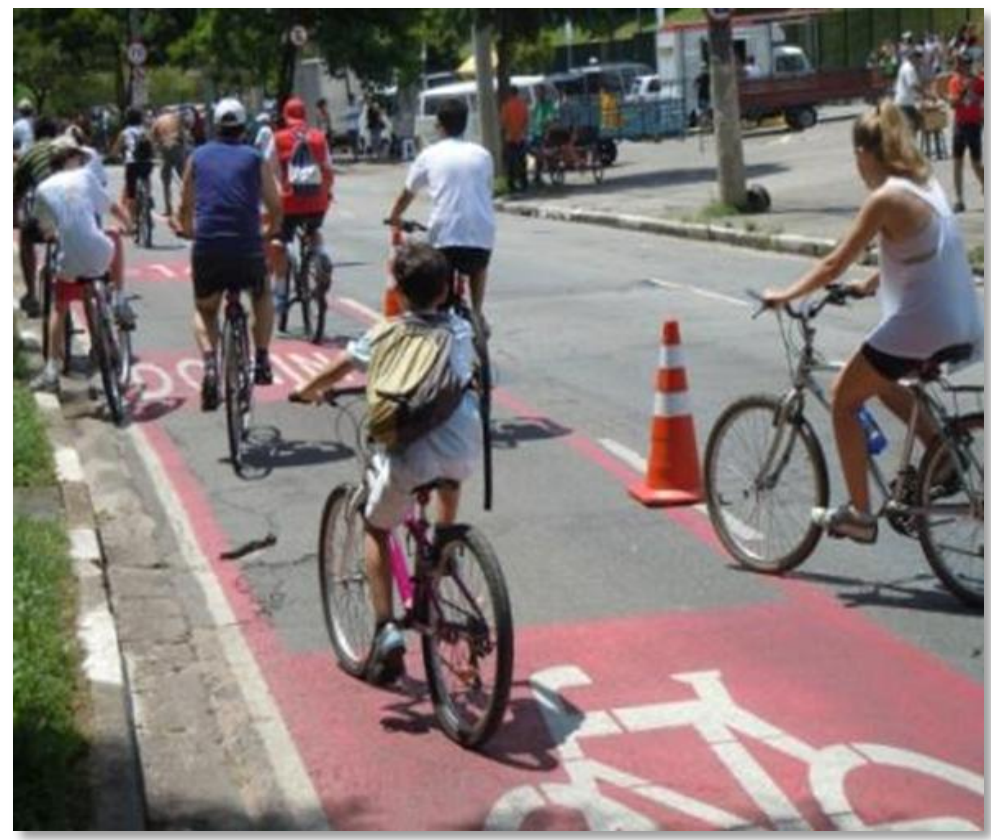

Foto 50 - Ciclofaixa de Lazer em funcionamento - desfrute de Espaços Públicos anteriormente percorrido no interior de veículos Foto: Arquivo DCL / CET - 2009

As Ciclofaixas de Lazer foram desenvolvidas para se adaptarem aos diferentes níveis de exigências de uso do espaço viário e, portanto são transitórias e flexíveis, com possibilidade de alteração de trajeto e posicionamento que atendam à dinâmica da cidade. São montadas e desmontadas nos dias permitidos ao seu funcionamento : domingos e feriados, das 07:00 às 16: horas. Nestes dias, por haver menor nível de atividade econômica na cidade, o espaço viário demandado pela geração de viagens, permite que se destine uma faixa de cada pista das vias que compõem a atual rede de $120 \mathrm{Km}$ de ciclofaixas de lazer, para uso exclusivo por bicicletas.

0 processo de montagem e desmontagem da Ciclofaixa de Lazer requer uma operação complexa somente possibilitada pela parceria financeira e logística da iniciativa privada, por exigir altos investimentos na compra e manutenção dos recursos materiais e operacionais, além do constante recrutamento e treinamento para mão de obra de apoio. Quanto aos recursos públicos, estes também são canalizados no planejamento, sinalização e coordenação da operacionalização da ciclofaixa.Entretanto, apesar dos altos custos, o programa Ciclofaixa de Lazer tem um retorno político e social consideráveis por abranger 
ações vinculadas ao Lazer, ao Esporte e à Educação de Trânsito que tornam os $120 \mathrm{Km}$ freqüentados em média por mais de 150 mil pessoas por domingo ${ }^{71}$, e atraído a atenção de prefeituras outras cidades brasileiras, interessadas em conhecer e aplicar seu modelo de gestão.
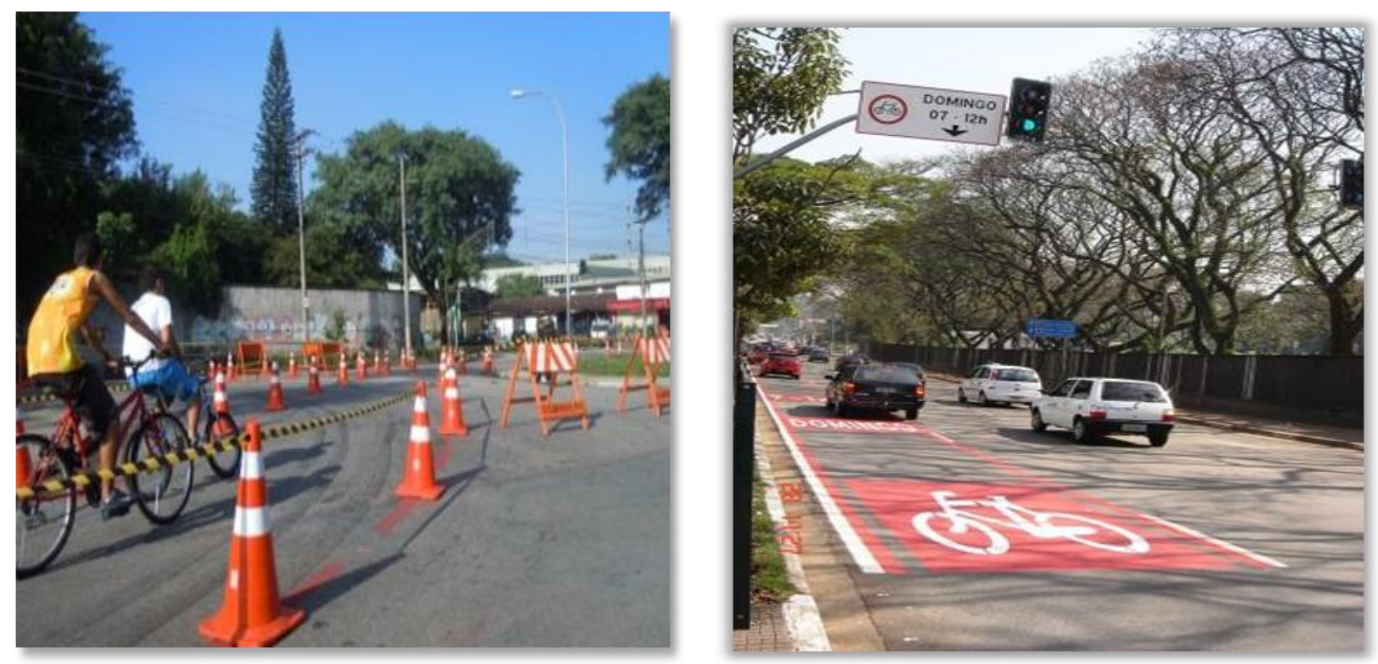

Foto 51 e Foto 52 - Ciclofaixa de lazer montada com material operacional e em dias normais: ocupada pelo fluxo veicular / sinalização vertical e horizontal

regulamenta

Foto: Arquivo DCL / CET - 2009

Os percursos da Ciclofaixas de Lazer estão situados junto a parques e áreas de interesse cultural e turístico da cidade, sendo o primeiro trajeto de $45 \mathrm{Km}$ elaborado com o intuito de ligar cinco parques da cidade: Parque das Bicicletas, Parque do Ibirapuera, Parque do Povo, Parque Villa-Lobos e Parque do Chuvisco, com $45 \mathrm{Km}$.

$\mathrm{O}$ segundo e terceiro trajetos atenderam a parques situado fora das áreas mais centrais, como o Parque da Juventude, na Zona Norte, com 8,5 Km e o Parque Linear Tiquatira, na Zona Leste, com $14 \mathrm{Km}$.

Posteriormente vieram os trajetos de caráter turístico e cultural que ligaram o primeiro trajeto dos parque

à Av. Paulista, Liberdade, Centro Histórico e Luz, perfazendo quase $40 \mathrm{Km}$. Por último a Ciclofaixa de Lazer chegou à região da Represa de Guarapiranga utilizando um trecho da Ciclovia do Rio Pinheiros, com quase $12 \mathrm{Km}$.

\footnotetext{
${ }^{71}$ Estimativa do site Ciclofaixa de Lazer
} 


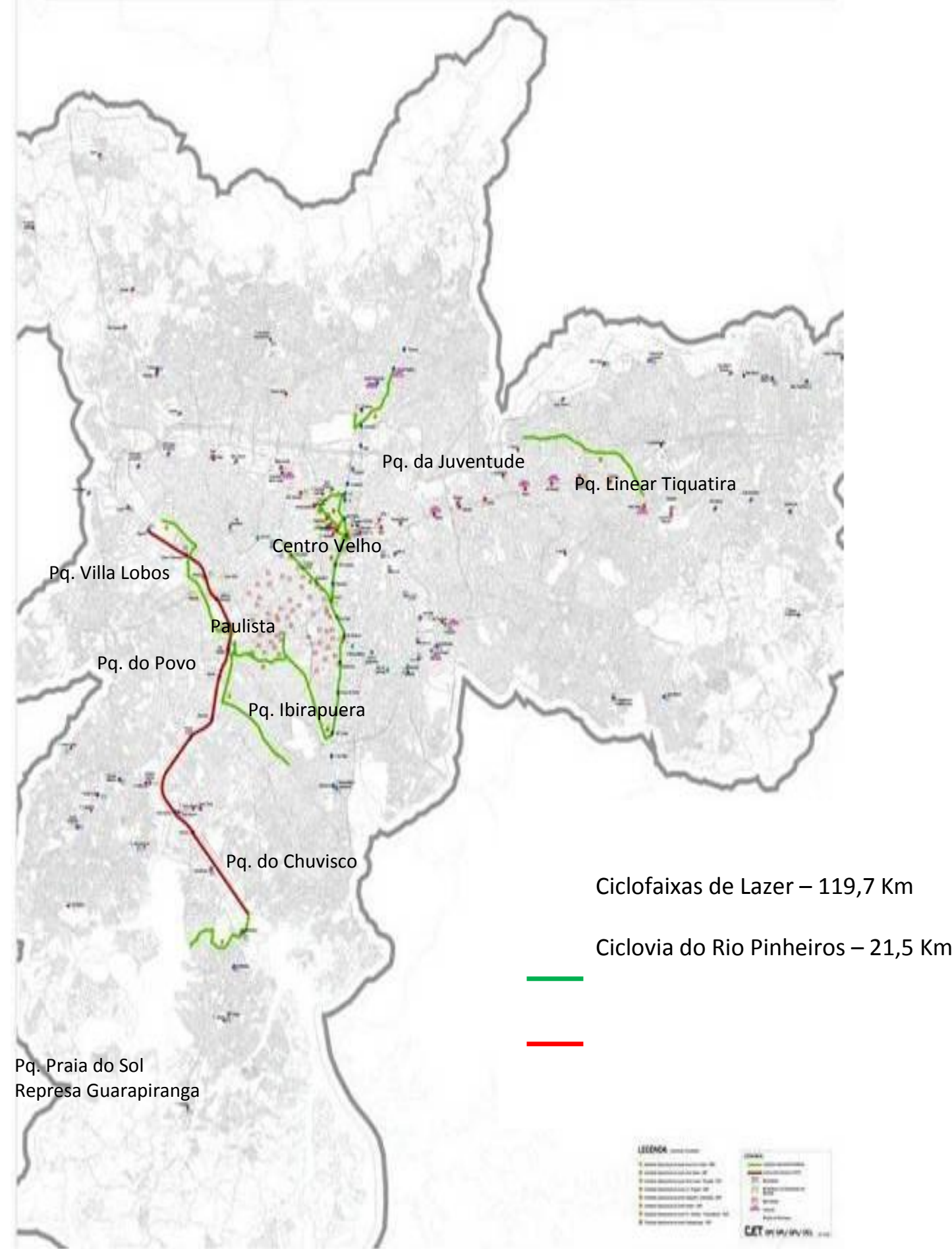

Mapa 14 - Ciclofaixas Operacionais de Lazer do Município de São Paulo: Domingos e Feriados das 07:00 às $16: 00$ hs

Fonte: CET / DCL - 2013 


\subsection{Programa de Proteção ao Ciclista}

Desde que a presença da bicicleta no trânsito paulistano começou a ficar mais intensa o número de conflitos no trânsito aumentou, apesar de não haver o aumento proporcional de acidentes fatais, como já foi exposto no item 3.4. deste trabalho, que aborda a vulnerabilidade do ciclista.

A intensificação da percepção das dificuldades enfrentadas cotidianamente pelos ciclistas decorre, a princípio, da fragilidade imposta ao condutor da bicicleta na disputa do espaço viário de circulação com o tráfego motorizado que foi acostumado a ter prioridade sobre a via.

Esta disputa complica-se ainda mais pelo desconhecimento do ciclista em relação aos seus direitos e deveres no trânsito já que não é obrigado a habilitarse e o que é pior, o atual processo de habilitação do motorista ignora sua preparação para conviver com o tráfego ciclístico, mesmo estando regulamentado pela lei (ver item 4.1.1 e Anexo I).

Este cenário acabou por apontar a necessidade de serem realizadas amplas campanhas educativas para todos os usuários da via quanto ao que é determinado pela lei em relação à circulação ciclística, pois muito motorista crê que o lugar da bicicleta é na calçada ou no interior dos parques.

A pressão política das ONGs de cicloativismo sobre o poder público no enfoque da vulnerabilidade do ciclista acabou resultando na criação, em 2012, de um programa específico do órgão de trânsito paulistano, o Programa de Proteção ao Ciclista. Ele consiste na intensificação da fiscalização de trânsito para motoristas que manifestam postura agressiva ou displicente em relação ao tráfego ciclístico. O programa iniciado em abril de 2012 consistiu em multar motoristas que desrespeitaram alguns artigos do CTB que levavam a insegurança ao tráfego ciclístico. Eles são os seguintes ${ }^{72}$ :

Artigo 169 - "Dirigir sem atenção ou sem os cuidados indispensáveis à segurança" ou seja, se aproximar demais do ciclista, forçá-lo a alterar seu percurso ou frear muito próximo à bicicleta. Infração leve

\footnotetext{
72 Folha de SP “Desrespeito ao ultrapassar ciclista rende só 19 multas" - 04/05/2013
} 
Art. 197 - Fica sujeito à punição quem fizer conversão à direita sem esperar o ciclista que vai seguir em frente. Infração média.

Art. 220 - Motorista que deixa de reduzir a velocidade ao ultrapassar o ciclista colocando sua segurança em risco. Infração grave.

Até março de 2013, onze meses após o início do programa, foram aplicadas mais de 8.825 multas relativas aos dois primeiros artigos que não são exclusivos para ciclistas, mas somente 19 multas relativas ao Art. 220, o que é muito pouco.

Entretanto ainda há um tipo de infração que os ciclistas cobram da CET a fiscalização dos motoristas, relativo ao Art. 201 do CTB: "Deixar de guardar a distância lateral de um metro e cinqüenta centímetros ao passar ou ultrapassar bicicleta"73. Este artigo é polêmico por ser de difícil autuação, de acordo com o órgão de trânsito, e o motivo alegado é a dificuldade de avaliação da exata medida da distância especificada na lei pelo fato de ambos, motorista e ciclista estarem em movimento. Entretanto seu cumprimento seria de extrema importância para a segurança do ciclista.

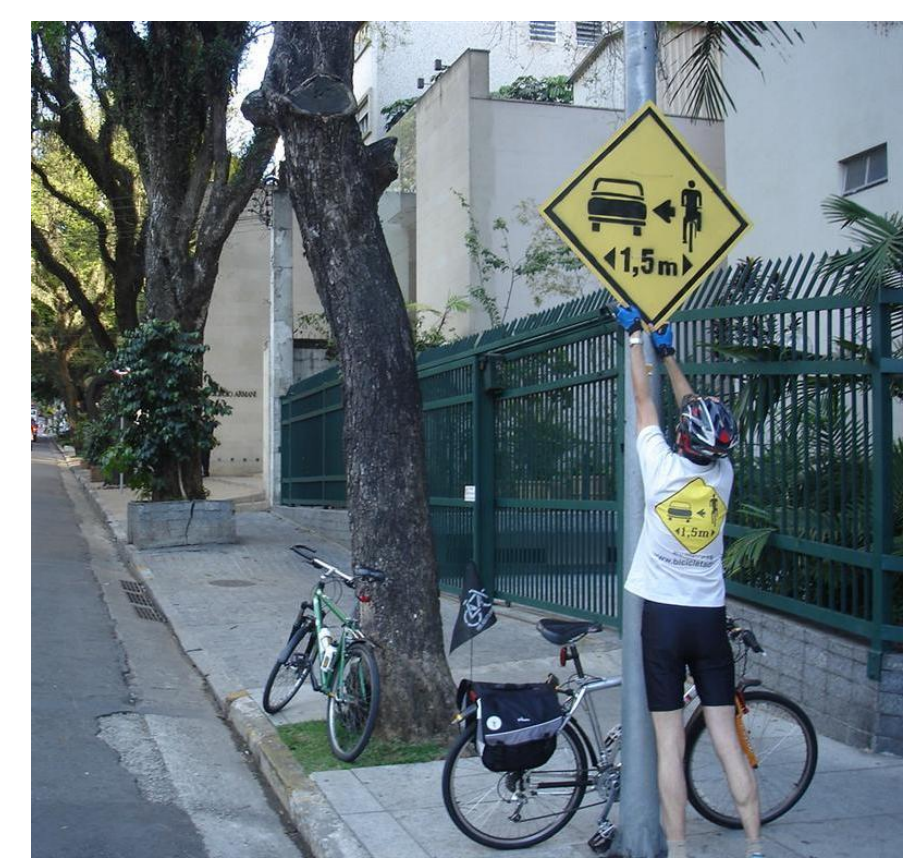

Foto 53 - Cicloativista instalando sinalização irregular sobre o Art. 201 Foto: Daniel Ingo Haase

$\overline{73}$ Art. 201 do Código de Trânsito Brasileiro - Lei Federal n 9.503, de 23 de setembro de 1997 


\section{A INFRAESTRUTURA CICLOVIÁRIA PREVISTA PARA O MUNICÍPIO DE SÃO PAULO}

A partir dos planos previstos pela prefeitura de São Paulo tomando como base o ano de 2013, observa-se o direcionamento das políticas cicloviárias no atendimento às demandas e necessidades que já haviam sido constatadas por estudos anteriores, tendo como uma de suas metas a execução dos $60 \mathrm{Km}$ de infraestrutura cicloviária prevista para as regiões de maior uso demanda e que já tem projeto executivo concluído. Estas regiões já haviam sido apontadas pela Pesquisa de Origem e Destino do Metrô de 2007 e basearam o Plano Cicloviário da Prefeitura de São Paulo.

De acordo com informações obtidas no portal da Prefeitura de São Paulo, estão em licitação $26,5 \mathrm{Km}$ de infraestrutura cicloviária na região do Jardim Helena:" A Prefeitura de São Paulo lançou licitação para a construção de $26,5 \mathrm{~km}$ de ciclovias, que ligarão as estações da CPTM de São Miguel Paulista, Jardim Helena, Itaim Paulista e a Estação Corinthians-Itaquera do Metrô, na Zona Leste. Chamado de Trecho 01 do Plano de Calçadas e Cicloviários no eixo Jardim Helena, Itaquera e Guaianases, o circuito passará pelas avenidas Doutor José Artur da Nova e Marechal Tito, além de a estrada Dom João Néri e o Mercado Municipal de Guaianazes"74.

Da mesma forma o programa de expansão dos corredores de ônibus, que foi um dos motes principais de campanha da gestão municipal iniciada em 2013, incorporou ações para sua compatibilização à rede de infraestrutura cicloviária já planejada assim como previu sua expansão para totalizar $340 \mathrm{Km}$ de ciclovias: "A cidade de São Paulo vai ganhar $340 \mathrm{~km}$ de vias cicláveis no ano que vem ciclovias, ciclofaixas e ciclorrotas... a gestão havia prometido fazer $400 \mathrm{~km}$ desse dispositivo ao longo do mandato inteiro de Haddad, dos quais $340 \mathrm{~km}$ devem sair no ano que vem.. ${ }^{, 75}$.

\footnotetext{
${ }^{74}$ Portal da Prefeitura do Município de São Paulo - “Prefeitura lança licitação para construção de 26,5 Km de ciclovias na Zona Leste" - 11/12/2013

75 O Estado de São Paulo - "Haddad promete transporte 24 horas e 340 Km de vias para bikes em 2014" $18 / 07 / 2013$
} 
É necessário e esperado também a consolidação dos programas educacionais para formação de condutores ciclistas no trânsito urbano assim como a continuidade das campanhas educativas para motoristas. 


\subsection{A infraestrutura de circulação cicloviária proposta}

Desde a definição da bicicleta como um dos ítens das políticas de mobilidade prioritárias do município de São Paulo a partir de 2005, finalmente se gerou um ambiente político favorável para colocar em prática recursos e incentivos já existentes para a sua implementação, representados por leis e decretos (detalhados no item 4.1.3).

Com coordenação ambientalista em 2005 situada inicialmente Secretaria Municipal do Verde e Meio Ambiente, o programa cicloviário do município de São Paulo passa em seguida para a esfera da política do transporte, com a transferência da coordenação para Secretaria Municipal de Transportes em 2009.

No âmbito metropolitano, apesar da ausência de legislação específica, essa condução fica sob a responsabilidade da Secretaria dos Transportes Metropolitanos e tem o acompanhamento da Secretaria Estadual do Meio Ambiente.

Nos dois níveis, entretanto, a condução da política ganhou corpo estimulada pela visibilidade que o tema adquiriu a partir da intensidade e do sucesso das experiências internacionais, amplamente divulgadas pela mídia, provocando reações altamente positivas na opinião pública geral e até na oferta de recursos oriundos da iniciativa privada que gerou a realização de parcerias públicoprivadas e financiamentos.

Muitas das subprefeituras prontamente reagiram através de iniciativas relativas ao desenvolvimento de suas próprias redes cicloviárias, começando a estruturálas com base nas indicações constantes nos Planos Regionais Estratégicos que passaram a contar, a partir de 2002, com o registro e indicação de vias com potencial para o tráfego ciclístico. Somadas a estas iniciativas e deflagrados por novos mecanismos legais representados pelas diretrizes impostas nas novas legislações que passaram a exigir o fornecimento de licenciamentos ambientais, além das exigências previstas pela Lei Municipal dos Sistemas Cicloviários (Lei $n^{\circ} 14.266 / 2007$ ), outras propostas de redes começaram a ser desenhadas e articuladas entre si. 


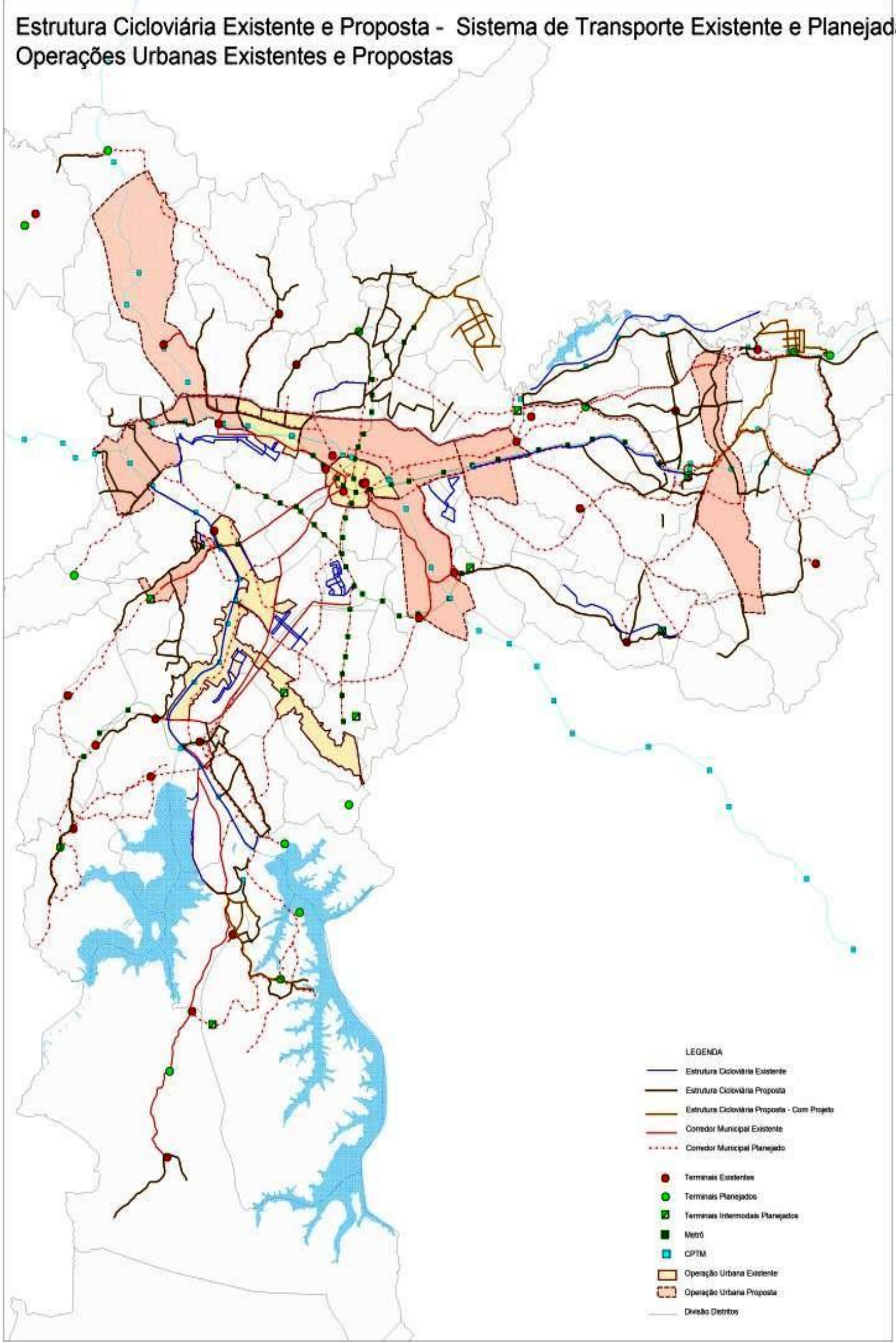

Mapa 15 - Infraestrutura cicloviária proposta constituída pelas propostas de redes cicloviárias de subprefeituras, operações urbanas, corredores de transporte 
e expansão metroferroviária.

Fonte: CET / Departamento de Planejamento Cicloviário - Março 2013

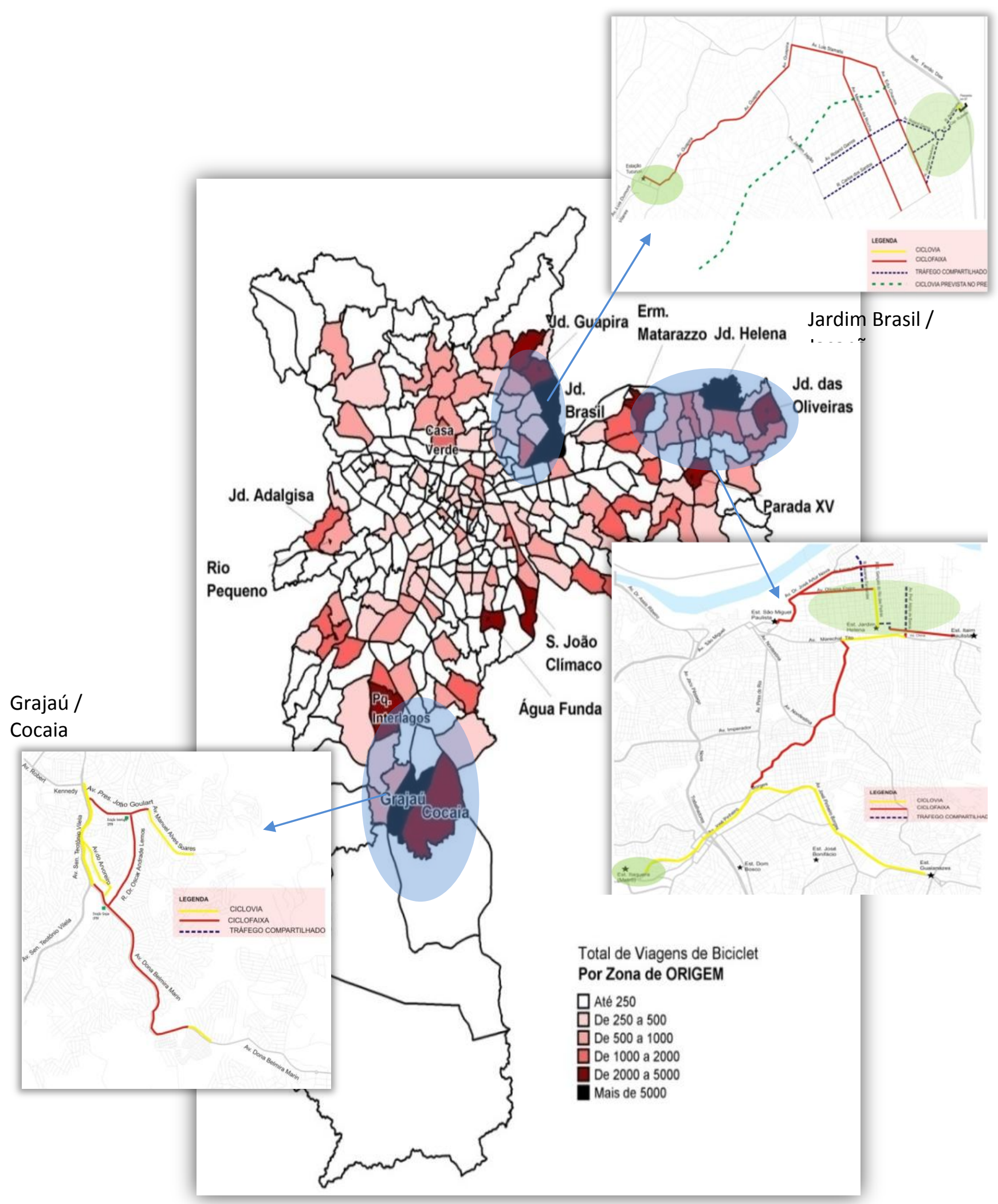

Figura 4 - Propostas de $55 \mathrm{Km}$ de infraestrutura cicloviária nas regiões do município com o maior número de viagens de bicicleta: Jardim Helena / Guaianases, Jardim Brasil / Jaçanã e Grajaú / Cocaia. 
Fonte: CET - Departamento de Planejamento Cicloviário - 2010

Mais recentemente, com as demandas trazidas pelo programa de ampliação dos corredores de ônibus, as propostas anteriormente elaboradas se expandem e acabam por desenhar a estrutura de uma rede cicloviária com potencial para atingir mais de mil quilômetros de extensão, abrangendo praticamente todas as regiões do município, como pode ser constatado no Mapa 14.

Compondo parte desta rede está o Plano de Ciclovias da Secretaria Municipal de Transportes elaborado pela CET em 2010. Este plano foi desenvolvido para atender a uma das metas principais de então, o planejamento e a implantação de pelo menos $100 \mathrm{Km}$ de infraestrutura cicloviária de circulação, iniciando com $55 \mathrm{Km}$ (Figura 4).

Este plano foi desenvolvido para regiões da cidade onde se constatou o maior número de viagens de bicicleta motivo trabalho pela última Pesquisa OD (2007) ${ }^{76}$ - ver Mapa 3. Posteriormente a este plano foi acrescido mais 5 (cinco) quilômetros de infraestrutura cicloviária situada nas principais avenidas do conjunto habitacional José Bonifácio situado na Zona Leste.

Apesar de detalhado até o nível de projeto executivo, as obras relativas às intervenções cicloviárias previstas pelo plano não foram implantadas até o momento pois além da dificuldade de priorização de recursos na própria prefeitura, existe um entrave técnico representado pela dificuldade de autonomia do órgão municipal que o desenvolveu, uma vez que a implantação das intervenções previstas pelo plano envolvem uma série de obras físicas que a CET, uma empresa que administra o trânsito da cidade, não tem aporte administrativo e financeiro para contratar. Ações deste teor são de competência de outras secretarias como Secretaria da Infraestrutura Urbana e Secretaria Municipal de Subprefeituras.

Atualmente a prefeitura abriu licitação para a implantação dos primeiros 26,5 $\mathrm{Km}$ situados na região do Jardim Helena (Subprefeitura de Itaim Paulista) conforme noticiado no Portal da Prefeitura de São Paulo ${ }^{77}: "$ Licitação abre concorrência para a execução do Trecho 01 do Plano de Calçadas e Cicloviários, no eixo Jardim Helena, Itaquera e Guaianases, com obras de readequação e

\footnotetext{
${ }^{76}$ Pesquisa de Origem e Destino do Metrô / 2007

${ }^{77}$ Notícia divulgada pelo Portal da Prefeitura de São Paulo em 11/12/2013: "Prefeitura lança licitação para construção de 26,5 Km de ciclovias na Zona Leste"
} 
revitalização do sistema viário entre a estação Corinthians-Itaquera e o Mercado Municipal de Guaianases.

A Prefeitura de São Paulo lançou licitação para a construção de $26,5 \mathrm{~km}$ de ciclovias, que ligarão as estações da CPTM de São Miguel Paulista, Jardim Helena, Itaim Paulista e a Estação Corinthians-Itaquera do Metrô, na Zona Leste. Chamado de Trecho 01 do Plano de Calçadas e Cicloviários no eixo Jardim Helena, Itaquera e Guaianases, o circuito passará pelas avenidas Doutor José Artur da Nova e Marechal Tito, além de a estrada Dom João Néri e o Mercado Municipal de Guaianases.

A previsão é de que as obras, que tem investimentos de $R \$ 20,7$ milhões, sendo $R \$ 17,1$ milhões liberados em setembro pelo Fundo de Desenvolvimento Urbano (FUNDURB) sejam iniciadas a partir de fevereiro de 2014. Outros dois trechos das obras, 02 e 03, que incluem serviços de melhoria da malha viária e complementares nos distritos de São Miguel Paulista e Jardim Helena, já estão contratados e as obras deverão ser iniciadas ainda neste mês. A previsão de entrega dos dois trechos é para janeiro."

Viabilizando a integração modal com os corredores de ônibus a SPTrans prevê a construção de bicicletários nos onze novos terminais de ônibus, cada um com dez vagas, sem cobrança de tarifas, conforme noticiado pela mídia" ${ }^{78}$ " Os onze novos terminais de ônibus municipais que a SPTrans promete entregar até 2016 contarão com bicicletários para os ciclistas guardarem suas bikes gratuitamente. Segundo a empresa que administra o transporte público da capital, a instalação dos espaços é um dos requisitos para quem disputar a concorrência para as obras.

Cada terminal terá no mínimo 10 vagas. Para utilizar o bicicletários os ciclistas precisam apenas fazer um cadastro com o documento de identidade. Eles também terão que levar corrente para prender a bike."

${ }^{78}$ Jornal Metro - “Novos terminais terão bicicletários" - 09/04/2013 


\subsection{Programa municipal de bicicletas públicas integradas à rede de corredores de ônibus}

A gestão municipal iniciada em 2013 teve como principal meta de transporte implantar treze novos corredores de ônibus na cidade e também planejar e instalar um serviço de empréstimo de bicicletas utilizando o atual sistema de cobrança de tarifa Bilhete Único, conforme consta em reportagem da Folha de São Paulo ${ }^{79}$ :

"A prefeitura planeja licitar um novo sistema de empréstimo de bicicletas na capital. A idéia é ter estações espalhadas por todas as regiões, com $50 \mathrm{mil}$ bicicletas.

O sistema deverá ser integrado aos ônibus e poderá ser usado com o cartão do Bilhete Único, mas o modelo ainda está em análise. O secretário municipal Jilmar Tatto não dá prazo para a licitação, mas diz que o projeto já foi apresentado ao prefeito Fernando Haddad (PT). Ele também não divulgou os custos envolvidos."

Para viabilizar este programa a prefeitura deveria definir o modelo econômico que viabilizasse a integração ao sistema de transporte proposto. Entretanto, ao contrário de muitas cidades que buscam recursos para seu custeio através de verbas oriundas da exploração comercial no mobiliário urbano como é o caso das cidades européias, em São Paulo a legislação municipal inviabilizou este mecanismo (Lei Cidade Limpa - lei municipal 14.223 / 2006 - ANEXO I).

Assim a prefeitura optou por ampliar o programa de bicicletas já existente, o Bikesampa e já está operando em caráter experimental, desde abril de 2013, três estações nas quais é possível utilizar a bicicleta através do Bilhete Único: ${ }^{80}$ "A Prefeitura de São Paulo inicia, nesta segunda-feira (6), o projeto piloto de integração do Bilhete Único com o projeto Bike Sampa. Com a novidade, exclusivamente os cadastrados no serviço poderão utilizar o cartão do transporte público para o empréstimo das bicicletas.

\footnotetext{
${ }^{79}$ Folha de SP "SP vai derrubar imóveis para fazer corredor de ônibus - Secretaria pode usar Bilhete Único para emprestar bike" - 10/04/2013

${ }^{80}$ Portal UOL - "Trânsito: Bilhete Único será integrado com o projeto Bikesampa a partir de hoje" $06 / 05 / 2013$
} 
O projeto inaugural contempla a implantação de leitores dos cartões de transporte da SPTrans em três estações estratégicas: Parque Trianon, Shopping Eldorado e Shopping Santa Cruz. Assim, o projeto de compartilhamento de bicicletas a integra definitivamente como um meio de transporte na capital paulista. A estação Parque Trianon interliga a bicicleta com corredor de ônibus e metrô; a estação Shopping Eldorado conecta a bicicleta com o trem e ônibus; e a estação Shopping Santa Cruz vincula a bicicleta com o metrô e ônibus.

\section{Cadastrar para usar:}

Para a primeira etapa da integração, 100 usuários, identificados a partir de levantamento de utilização no banco de dados do Bike Sampa, poderão liberar as magrelas através do Bilhete Único. No entanto, a utilização não ficará restrita. Quem quiser emprestar uma bicicleta deve atualizar seu cadastro junto ao projeto, incluindo o número do bilhete."
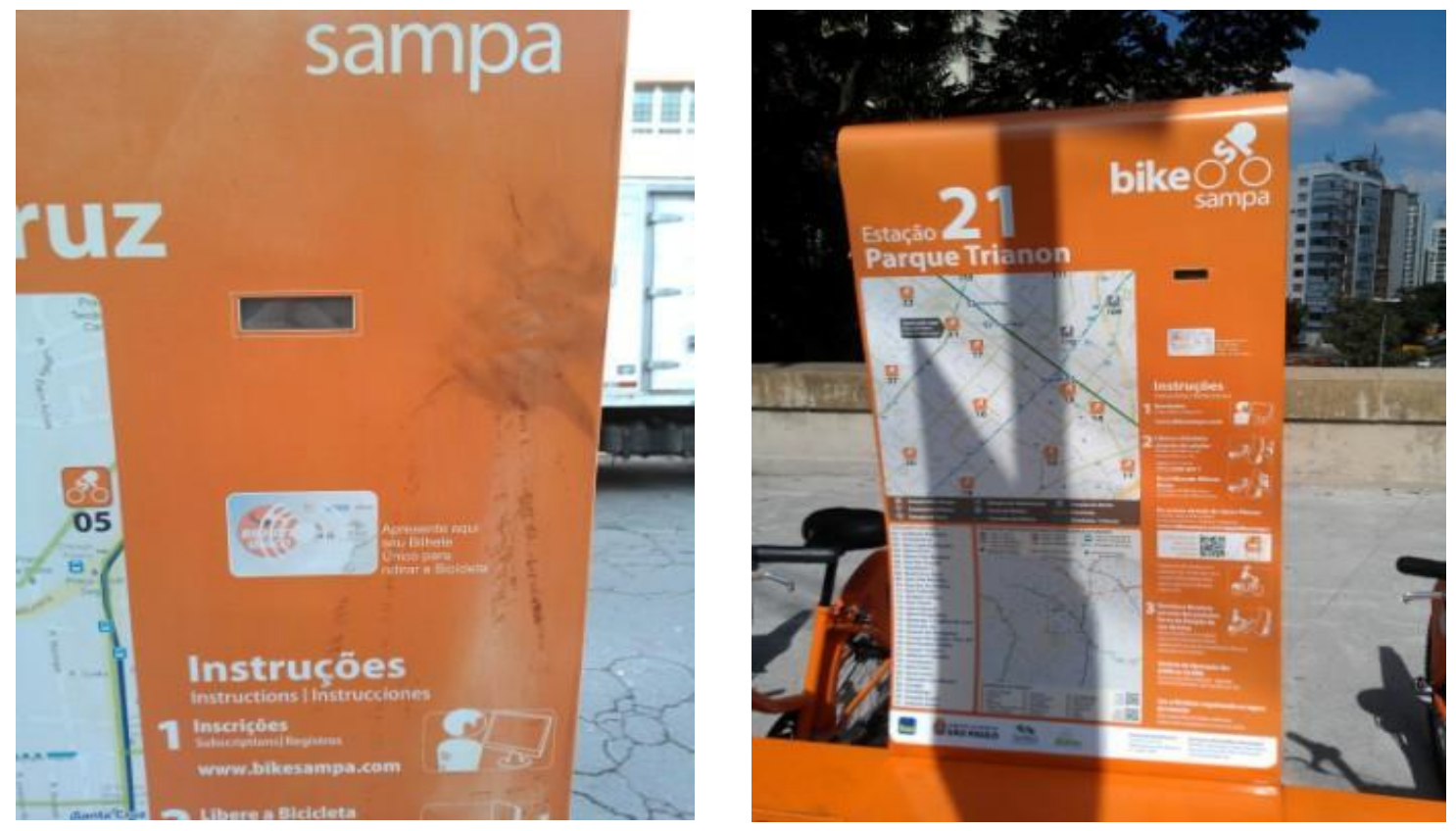

Foto 54 e Foto 55 - As primeiras estações do Sistema Bikesampa onde a tarifa de uso da bicicleta pode ser paga com o Bilhete Único - em operação desde 27/05/13 Foto: Arquivo DCL / CET - 2013

Atualmente no sistema Bikesampa há mais 1.000 bikes disponíveis para empréstimo. Elas podem ser utilizadas por 30 minutos e devolvidas em qualquer uma das várias estações do projeto - a maioria situada na zona sul.

A partir de novembro de 2013 a Prefeitura e os parceiros privados que patrocinam o projeto iniciaram a instalação de mais estações - todas com leitor 
de bilhete único e em bairros da região central. A expansão colocará mais mil bikes à disposição em 2014 na Zona Leste.

Para estar apto a utilizar este sistema o usuário deverá ter seu Bilhete Único cadastrado ${ }^{81}$ : "Neste primeiro momento, o serviço estará disponível apenas para 100 pessoas já cadastradas a partir de um levantamento no banco de dados do Bike Sampa. Posteriormente, porém, o serviço será estendido. Os interessados devem atualizar seu cadastro no projeto, incluindo o número do bilhete.As regras para quem emprestar as bicicletas com o Bilhete Único serão as que já valem no Bike Sampa. O veículo pode ser usado por 30 minutos e poderá ser devolvido em qualquer estação do projeto, ainda que esta não possua um validador do cartão."

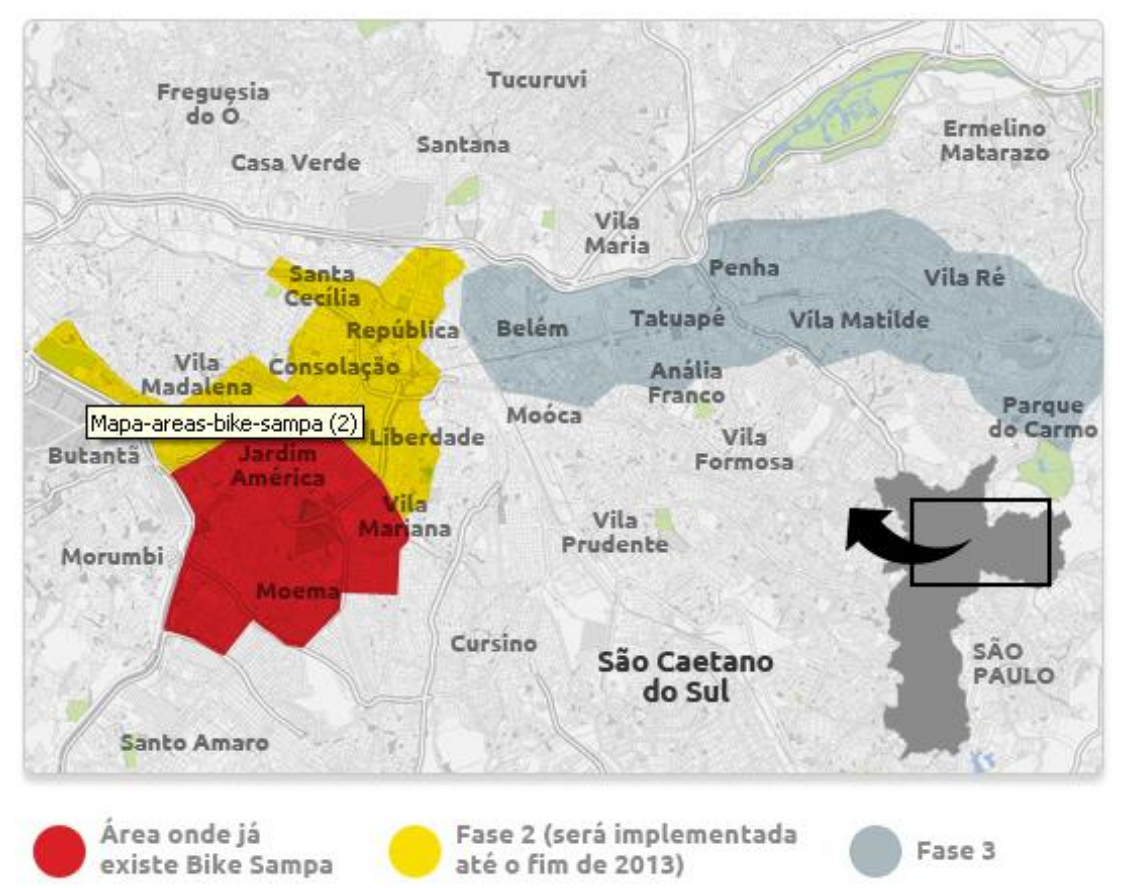

Figura 5 - Áreas de localização do Sistema Bikesampa atuais e futuras Fonte: Revista Veja SP - edição de 24/05/2013

No segundo semestre de 2013 o programa Bikesampa expandiu mais 100 estações para o Centro e Zona Oeste e em 2014 deverá ir para a Zona Leste do município com mais 100 módulos previstas até o final de 2014"2: "Até o fim de 2013, duas mil bikes já deverão circular pela cidade. Neste ano, 100 novas estações serão instaladas, na Zona Oeste e na região central. 0 próximo passo será, portanto, a expansão para a Zona Leste." (ver Figura 4).

\footnotetext{
${ }^{81}$ Folha de SP "SP testa uso do Bilhete Único no empréstimo de bicicletas" - 02/05/2013

${ }^{82}$ - Revista Veja SP - Bikesampa vai se expandir para a Zona Leste - 24/05/2013
} 


\subsection{Curso da Prefeitura de SP "Pedalar com Segurança”}

O condutor da bicicleta, ao contrário do condutor dos modos de transporte motorizados, não precisa passar por um processo de habilitação que the permita conhecer a legislação e a sinalização de trânsito, preparando-o assim para circular no sistema viário com eficiência e segurança.

Por este motivo muitos dos usuários cotidianos de bicicleta não tem consciência de que são definidos como condutores de veículos pela legislação, tem que atender às regras dispostas por esta legislação e também gozam de direitos e prerrogativas.

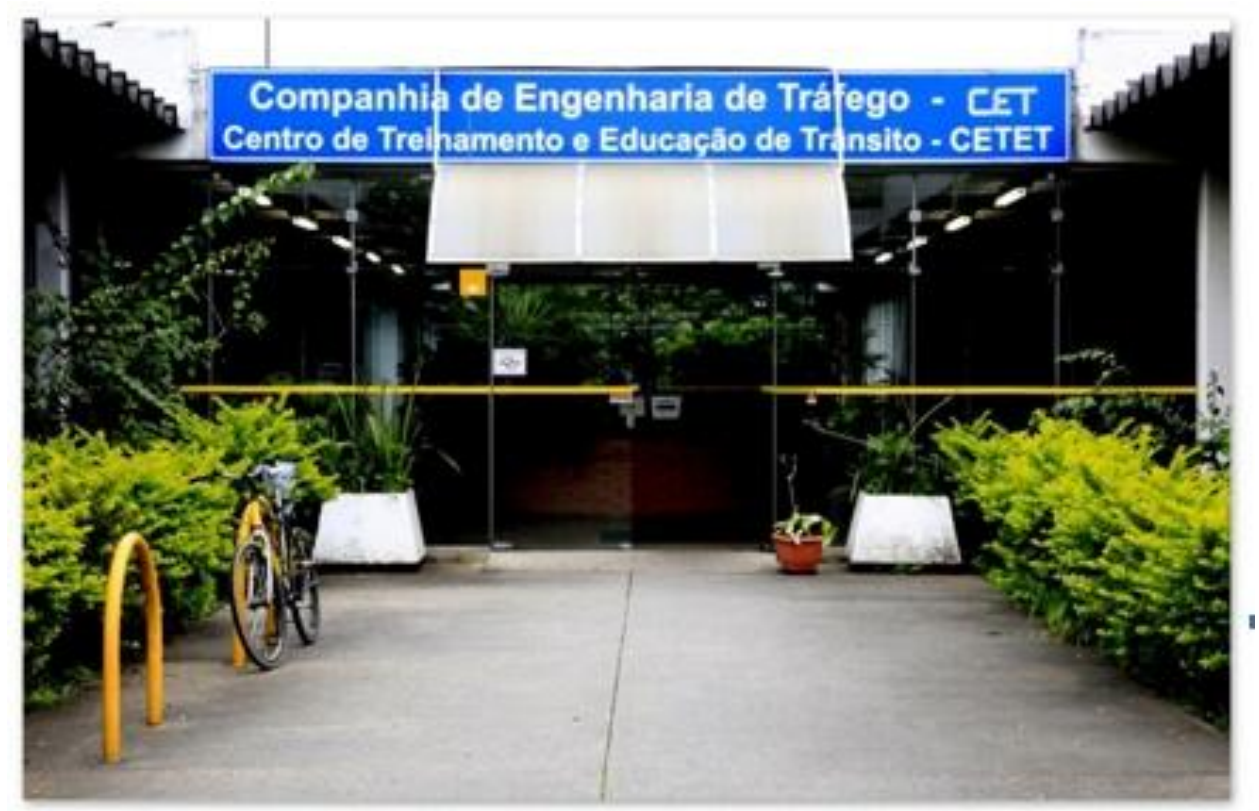

Foto 45 - Centro de Educação de Trânsito da CET SP onde será ministrado o Curso para ciclistas Pedalar com Segurança Foto: Arquivo do DCL

Da mesma forma estes usuários se aventuram em utilizar bicicleta no sistema viário paulistano sem o preparo e conhecimento técnico e prático desejáveis, principalmente em relação à legislação e às posturas defensivas de direção. Muitos também não tem noções de regulagem e manutenção de seu veículo, o que é fundamental para a sua segurança e integridade.

Para atender a estas demandas a prefeitura, através da CET, passa a ministrar para a população um curso específico para preparar ciclistas para utilizar de 
forma segura e responsável seus veículos no sistema viário da cidade, além de fornecer noções de direção defensiva e manutenção básica da bicicleta.

Para tanto foi projetado e construído um espaço específico onde se encontram reproduzidas todas as alternativas de infraestrutura cicloviária de circulação que o condutor da bicicleta encontrará na cidade, para que ele possa reconhecê-las e saber como circular com segurança em todas elas (Fotos 45,46 e 47).

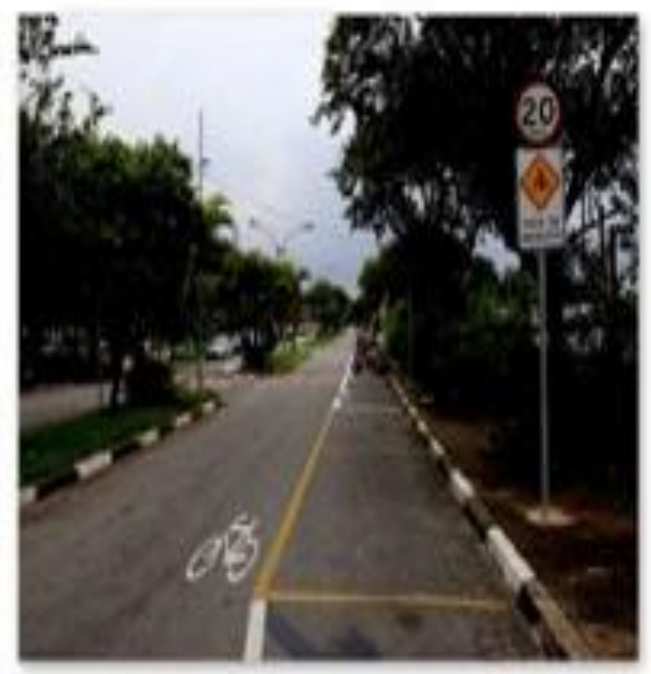
Fotos 46 e 47 -espaço especialmente projetado para o curso “Pedalar com Segurança” Foto: Arquivo do DCL

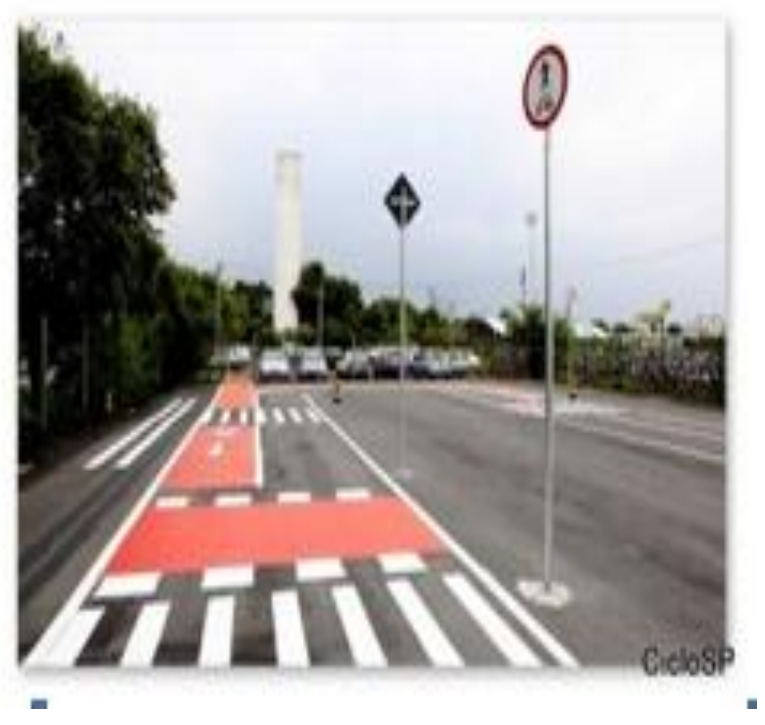




\subsection{Campanha educativa de trânsito sobre bicicleta}

Esteve em divulgação pela prefeitura de São Paulo campanha educativa de trânsito chamando a atenção do público para a presença da bicicleta nas ruas da cidade e expondo os direitos e deveres de todos em relação à circulação ciclística. Esta campanha foi um compromisso da prefeitura com os cicloativistas após a ocorrência de um acidente de trânsito com um ciclista: ${ }^{83}$ “Após se reunir com cicloativistas na manhã de ontem, o prefeito Fernando Haddad (PT) anunciou que vai criar uma campanha educativa na mídia para ajudar motoristas e ciclistas a conviverem nas ruas da cidade. A ideia é que o material seja veiculado em meios como televisão e rádio, em uma tentativa de diminuir os índices de acidentes e mortes de usuários de bicicleta na capital.

"Nós temos que garantir um plano de comunicação para que as pessoas se informem e entendam melhor este movimento, para dar mais segurança aos ciclistas", afirmou o prefeito.

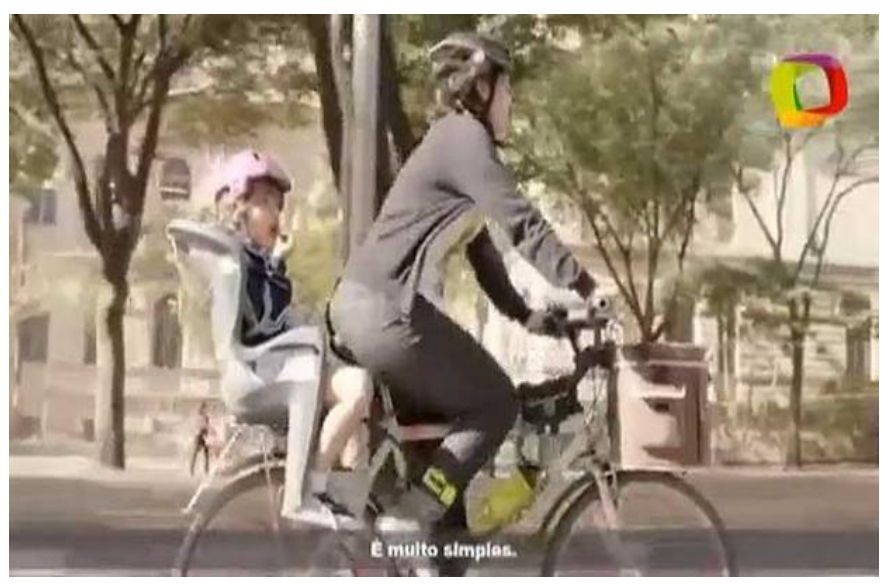

Foto 56 - Imagem de um dos filmes da campanha educativa da PMSP que foi ao ar em agosto de 2013

Fonte: Site Terra

Para o cicloativista Willian Cruz, autor do blog Vá de Bike, a campanha deverá ser positiva. "Um dos maiores problemas que temos hoje é o motorista que acha que a bicicleta não deve estar na rua, e a campanha servirá justamente para diminuir isso", afirmou."

\footnotetext{
83 O Estado de São Paulo - "Bicicleta terá campanha de trânsito em SP" - Caderno Cidade 23/03/2013
} 


\section{CONCLUSÕES}




\section{Conclusões}

Este trabalho pode mostrar que mesmo não sendo uma cidade que ofereça de imediato um ambiente favorável ao tráfego ciclístico é cada vez mais intenso nos últimos anos o uso da bicicleta como modo de transporte cotidiano em todo o município de São Paulo.

Muito embora a utilização da bicicleta no dia a dia tenha sido tema de estudos pelos órgãos de transporte e trânsito desde a crise do petróleo dos anos oitenta, as ações resultantes destes estudos nunca saíram do papel. O principal motivo foi a prioridade das políticas de mobilidade da época, totalmente direcionadas para o transporte motorizado individual, mesmo com o comprometimento da estruturação de um sistema de transporte compatível ao tamanho da metrópole paulistana. Outro motivo era a forte associação da bicicleta como instrumento de lazer e esporte, não havendo na ocasião ações políticas e leis que a caracterizassem como veículo .

Trinta anos depois, a partir do primeiro decênio dos anos dois mil, passa a ser constatada uma intensificação espontânea da presença da bicicleta como mais um elemento componente do deslocamento diário do paulistano. Demandada por vários fatores, teve certamente como o principal, a já mencionada situação de falência do transporte público. A esta constatação, não por acaso, acumulamse dois outros fatos: um deles constituído pelo aumento do número de viagens diárias em função do aquecimento da economia, e o outro a consequente busca de alternativas de mobilidade para evitar, ou ao menos minimizar, a queda de qualidade de vida provocada pelo aumento do tempo perdido nos deslocamentos diários.

Na década entre 1997 e 2007, a Pesquisa de Origem e Destino do Metrô de 2007 registra um expressivo aumento ( quase $200 \%$ ) de viagens diárias por bicicleta na Região Metropolitana de São Paulo. Mesmo não pontuando um dígito na matriz modal metropolitana e municipal ( $0,8 \%$ do total de viagens na Grande São Paulo e $0,6 \%$ no município), este crescimento revelou que uma parte da população 
passou a recorrer ao uso cotidiano da bicicleta, certamente como alternativa de contorno aos problemas enfrentados em seus deslocamentos diários.

Enquanto se aguarda pela próxima Pesquisa de Origem e Destino do Metrô, basta olhar para as vias paulistanas e notar a presença cada vez maior de bicicletas transitando em diferentes regiões da cidade, utilizada por estratos distintos de população para funções diversificadas, até como veículo de carga, em substituição aos pequenos furgões e motos.

Neste mesmo período entra em curso no pensamento da autoridade pública e da sociedade a preocupação com as condições de preservação do meio ambiente e dos recursos naturais, fazendo desejáveis e estimulados usos e hábitos simples e autônomos, que impliquem na utilização de fontes de energia renováveis.

Boas experiências de muitas cidades ao redor do mundo que investiram intensamente no uso da bicicleta para o deslocamento cotidiano passam a servir de referência para programas de governo e reivindicações de vários setores organizados da sociedade paulistana. Assim começam a surgir propostas para investimentos em políticas cicloviárias como solução para o atual impasse da mobilidade, muitas das quais desconsiderando o importante fato de que as características da viagem ciclística dificilmente pode situá-la como alternativa única para suprir as tarefas cumpridas pelos serviços de transportes públicos coletivos, principalmente numa metrópole com a dimensão de São Paulo. Portanto, considerando as características do veículo bicicleta, fazem-se necessários para viabilizar sua utilização cotidiana, além do investimento em infraestruturas físicas, a consolidação de políticas sociais e institucionais que deem o necessário suporte a ela e ao seu condutor.

Neste sentido, a atual legislação cicloviária, nas esferas federal, estadual e municipal, procurou consolidar de forma clara e acertada a função e a importância da bicicleta enquanto elemento componente da mobilidade urbana. Ampliou sua utilização para além das limitadas fronteiras de instrumento para a prática de esporte e lazer. Entretanto esta situação apresenta ainda alguns aspectos que exigem apuro para viabilizar as emergentes políticas públicas de utilização cotidiana da bicicleta nas cidades, em especial as de grande porte como São Paulo. 
A começar pelo Código de Trânsito Brasileiro que em 1997 passa a definir a bicicleta como veículo não motorizado e dá ao seu condutor o direito de circular na via junto ao tráfego geral independentemente da idade. Ao mesmo tempo em que determina, acertadamente, as prioridades requeridas pela situação de vulnerabilidade em relação ao tráfego motorizado, não objetiva a preparação do ciclista para ser um condutor e nem estabelece algum tipo de controle sobre seu comportamento, em relação a ele mesmo e em relação aos demais usuários da via, o que o coloca muitas vezes de vítima do tráfego motorizado à algoz do agente mais vulnerável do sistema da mobilidade urbana, o pedestre.

Em relação aos motoristas a situação é igualmente crítica porque mesmo sendo uma categoria onde a habilitação para a direção é obrigatória, o processo de preparação do condutor do veículo motorizado ignora, até o momento, a presença do veículo bicicleta na via. Assim este condutor não é orientado como proceder, de acordo com a lei, quando convive com o veículo bicicleta e não aprende a respeitá-la como componente do trânsito urbano, valendo para ele a lei do mais forte e do maior.

As leis estaduais paulistas com relação à bicicleta também deixam a desejar porque são restritas, genéricas e até 0 momento não exploraram adequadamente mecanismos para viabilizar a criação de políticas para a estruturação e consolidação de rede cicloviária metropolitana. Isto ocorre apesar da presença e a constante ampliação de infraestrutura de integração modal (bicicletários, paraciclos e bicicletas públicas) nas estações dos sistemas de transporte metropolitanos sobre trilhos da CPTM - Companhia Paulista de Trens Metropolitanos e do Metrô de São Paulo.

Em relação à legislação municipal paulistana, ao antigo conjunto de leis municipais voltadas, em sua maioria, ao uso da bicicleta como lazer, foram acrescentadas recentemente novas leis, decretos e portarias. Eles objetivam a criação de um ambiente político propício a estruturação de uma rede cicloviária que estimule o uso cotidiano da bicicleta como modo de transporte único ou integrado aos sistemas existentes, assim como estabelecem mecanismos que tornam obrigatória a implantação de infraestrutura cicloviária de circulação e apoio (bicicletários, bicicletas públicas) no município. Entretanto, mesmo com estes mecanismos, a situação de desestruturação dos sistemas de transporte, a 
priorização dada ao automóvel e o gigantismo da cidade com seus mais de dezessete mil quilômetros de rede viária ${ }^{84}$ tem levado à implantação de redes cicloviárias tímidas, isoladas e desarticuladas entre si. Esta situação poderá modificar-se futuramente se houver continuidade dos programas municipais que priorizem a bicicleta como transporte voltando-se primeiramente para a população que mais a utiliza não só para transporte próprio como também para o transporte de mercadorias através do estímulo ao bicifrete.

Em confronto à constatação desta necessidade, esta tese também deixa registrada a influência da participação de setores organizados da sociedade no processo de estruturação do transporte cicloviário no município. Ela ocorre através de reivindicações destes setores, sempre articulados à mídia e ao poder público, e quase nunca representativos dos majoritários segmentos sociais usuários da bicicleta, conforme demonstrado pelo perfil do usuário de bicicleta paulistano e as áreas onde está localizada a demanda, de acordo com a Pesquisa OD do Metrô. Isto provoca distorções na hora de aplicar os parcos recursos públicos das políticas cicloviárias, direcionando-os à implantação de infraestrutura em regiões onde não se dá o maior registro de viagens ciclísticas ou não aproveitando adequadamente as poucas infraestruturas implantadas e que poderiam atender a estas populações, como é o exemplo do Parque Zilda Arns.

Para evitar este tipo de distorção se faz necessária a abertura de canais de diálogo entre o poder público e os seguimentos da sociedade atualmente marginalizados do processo, de forma a garantir acesso às demandas e anseios da população majoritariamente usuária da bicicleta, que normalmente não conta de meios para se articular em associações e organizações não governamentais. Também seriam muito necessárias e bem-vindas outras formas de identificação da demanda ciclística na cidade através da realização de pesquisas a elas específicas, pois atualmente esta demanda é aferida somente através Pesquisa de Origem e Destino do Metrô, cujo objetivo principal certamente não é o registro da mobilidade ciclística.

Outro item abordado neste trabalho foi referente ao tratamento do transporte cicloviário pelas estratégias de marketing através de parcerias público-privadas.

\footnotetext{
${ }^{84}$ Portal da Prefeitura do Município de São Paulo - "São Paulo em Movimento" - Extensão do viário: 17.289 $\mathrm{Km}$
} 
Atualmente as empresas envolvidas nestas parcerias estão mais preocupadas em investir nas regiões da cidade onde podem obter maiores vantagens quanto à visibilidade e retorno comercial. Neste sentido faz-se imprescindível a presença de mecanismos legais de controle pelo poder público, de forma a garantir que a captação de recursos para a estruturação e otimização do transporte cicloviário seja direcionada para os locais onde haja demanda, independentemente de haver ou não retorno financeiro. Só assim pode ser garantido apoio não só à criação de infraestruturas cicloviárias como também aos projetos educacionais e campanhas educativas voltadas à inserção da bicicleta na mobilidade cotidiana da cidade.

Apesar do município de São Paulo apresentar todas as dificuldades características das metrópoles de viário densamente ocupado pelo tráfego motorizado, o redirecionamento e ocupação de parte viário para o tráfego ciclístico sofre ainda grande resistência por vários motivos expostos ao longo deste documento. Por este motivo o cenário que paulatinamente vai se estruturando é formado por uma tímida rede cicloviária que até o momento da conclusão deste trabalho conta com $125 \mathrm{Km}$ de ciclovias, ciclofaixas e ciclorrotas $^{85}$ definitivas, ainda descontínuas e desarticuladas. Como já afirmado anteriormente, grande parte desta infraestrutura de circulação foi implantada sem ser precedida por estudos e planejamento, necessários a garantir um bom retorno de utilização e assim compensar investimento público realizado e respaldar a opção política pelo uso cotidiano da bicicleta.

Somadas aos $125 \mathrm{Km}$ de rede cicloviária definitiva, $120 \mathrm{Km}$ de ciclofaixas operacionais de lazer operam aos domingos e feriados. Apesar de não se destinarem a princípio a uma função utilitária, apresentam intensa aceitação e utilização pela população numa cidade carente de parques e áreas de lazer como é São Paulo. Além do lazer, estas ciclofaixas tem um papel importantíssimo na divulgação do conceito de uso da bicicleta como forma de mobilidade cotidiana não só para seus usuários como também para demais, motoristas e pedestres, educando-os e preparando-os para uma convivência harmoniosa e pacífica .

${ }^{85}$ Dados da CET / GPL / DCL 2013 
Mesmo contando com esta acanhada rede de circulação definitiva e operacional, o uso da bicicleta no deslocamento diário paulistano está crescendo em parte estimulado e justificado pela oferta de quase cinco mil vagas de bicicletários, majoritariamente situadas nas estações do Metrô da $\mathrm{CPTM}^{86}$,e em menor número nos terminais da SPTrans, com previsão de novos bicicletários nos terminais dos futuros corredores de ônibus. Motivam também a perspectiva de aumento das viagens ciclísticas em integrações modais, os serviços de bicicletas compartilhadas com algumas estações já integradas ao transporte público pelo Bilhete Único. Contam atualmente com mais de mil bicicletas ${ }^{87}$ e tem previsão de chegar a três mil até o final de 2014.

Os planos futuros da prefeitura do município de São Paulo visam, a princípio, atender às regiões do município com demanda ciclística constatada assim como intensificar e consolidar a integração da bicicleta ao transporte coletivo pela implantação de mais $300 \mathrm{~km}$ de infraestrutura cicloviária de circulação. Esta meta poderá até ser superada se saírem do papel outros estudos e projetos cicloviários que se encontram em andamento na prefeitura, acompanhados pela área responsável da $\mathrm{CET}^{88}$. São constituídos pelas intervenções cicloviárias dos Planos Regionais de algumas subprefeituras, além de ciclovias previstas pelos licenciamentos ambientais e operações urbanas.

Ações complementares importantes como a construção do espaço e do curso de treinamento para ciclistas adultos e jovens, acompanhada por campanhas educativas além de reforço na fiscalização dos motoristas, já foram testadas e iniciadas e poderão se tornar ações sistemáticas das políticas cicloviárias da prefeitura de São Paulo.

Ainda fazem falta medidas complementares constituídas pela expansão dos programas de redução de velocidade veicular restritos às vias arteriais e coletoras através da criação de "Zonas 30"89 , medida esta fundamental para possibilitar a circulação segura da bicicleta, e a definição de mecanismos para efetivar algum tipo de controle sobre o comportamento do ciclista enquanto

\footnotetext{
${ }^{86}$ Dados Metrô e CPTM 2013

${ }^{87}$ Dados obtidos junto à CET / GPL / DCL em agosto de 2013

88 Dados obtidos junto à CET / GPL / DCL em agosto de 2013

${ }^{89}$ Delimitação de área onde a velocidade máxima permitida é $30 \mathrm{Km} / \mathrm{h}$ como medida de acalmamento de tráfego. Viabiliza a circulação ciclística sem a implantação de infraestrutura exclusiva. (Nota da autora)
} 
condutor no trânsito urbano, importante sobretudo nas situações de proximidade de convivência com a Mobilidade a Pé.

Portanto, os fatos expostos nesta tese, permitiram refletir sobre o verdadeiro papel da bicicleta na matriz modal do deslocamento cotidiano do município de São Paulo assim como apontaram a importância do veículo bicicleta na mobilidade paulistana. Destacando alguns resultados positivos e outros nem tanto, pretendeu-se demonstrar as formas como as políticas públicas e a sociedade tem tratado a bicicleta como meio de transporte e como poderão consolidá-la enquanto elemento componente da mobilidade paulistana em sua escala municipal e metropolitana e, partir desse enfoque, verificar como ocorre sua inserção na atual rede de mobilidade cotidiana, cujos deslocamentos concentram-se majoritariamente no Transporte a Pé e no Transporte Coletivo.

Desta forma políticas públicas e ações sociais que visem incluir definitivamente o uso diário da bicicleta no ambiente da mobilidade paulistana, devem antes de tudo entender, respeitar e explorar suas características e potencialidades e assim compor, juntamente com as demais intervenções urbanas e institucionais, um cenário propício a promover um salto de qualidade na vida de nossa cidade. 
8. POSFACIO 


\section{Posfacio}

Durante a realização da apresentação desta tese de doutorado, ocorrida no dia 26 de março de 2014, a banca julgadora presidida pela Prof $^{a}$ Dr $^{a}$ Klara Anna Maria Kaiser Mori, com a participação dos professores doutores Csaba Deák e Andreina Nigriello da FAU-USP, Silvana Maria Zioni da UFABC e Eduardo Alcantara de Vasconcelos da ANTP, algumas observações feitas levaram à necessidade da elaboração deste posfacio contendo registros complementares.

Primeiramente cabe ressaltar que o trabalho assinala a existência de dois públicos distintos quanto aos motivos de procura da bicicleta, embora ambos ligados à tentativa de melhoria da qualidade de vida através da redução do tempo despendido em seus deslocamentos diários.

Um deles, majoritário, é constituído pela população de baixa renda, moradora de bairros situados nas franjas da cidade e mal servida pelos atuais sistemas de transporte coletivo. Este segmento social encontra no deslocamento por bicicleta a oportunidade de melhorar sua situação econômica ao poupar o preço de tarifa quando não há integração modal, e otimizar o tempo de validade do bilhete dos sistemas de tarifa unificada, quando a viagem de bicicleta é integrada aos sistemas de transporte. Em ambos os casos, constata-se a fuga à situação de extremo desconforto dos sistemas de transporte saturados e a busca por uma melhor qualidade de vida pela redução do tempo gasto nas demoradas viagens além da já mencionada economia representada pelo alto custo da tarifa. Já o público usuário da bicicleta pertencente à classe média moradora dos bairros situados no Centro Expandido encontra na utilização diária da bicicleta uma forma de reduzir o tempo gasto nos deslocamentos ao se livrar dos congestionamentos que certamente enfrentaria se estivesse no interior de seus automóveis.

Esta atitude das classes econômicas mais favorecidas encontra respaldo na atual postura de consciência ambientalista que estimula modos de vida saudáveis individual e coletivamente. Elegem a bicicleta como a forma de transporte ideal por garantir a mesma autonomia do automóvel para a grande maioria dos deslocamentos individuais, não poluir, não consumir espaços urbanos e 
principalmente por esse veículo não exigir comprometimento com posturas e obrigações legais e institucionais: a bicicleta é livre de leis e impostos.

Ao mesmo tempo os dados apresentados na tese possibilitam refletir sobre o que a mobilidade cicloviária representa na estruturação da matriz modal cotidiana de viagens, tanto no município de São Paulo como sua região metropolitana em relação à realidade das cidades brasileiras. Enquanto a representatividade das viagens ciclísticas no município de São Paulo não passa de $0,6 \%$ do total de viagens, significando quase metade do padrão de $1 \%$ verificado nas cidades brasileiras de grande porte (população > 1 milhão de habitantes), de acordo com a ANTP - Associação Nacional dos Transportes Públicos, o da região metropolitana fica mais próximo a este padrão ( $0,8 \%)$, mas também não chega a atingir $1 \%$.

Se compararmos estes padrões de viagens ciclísticas aos praticados em cidades como Amsterdã (quase 40\%) ou mesmo Bogotá (3\%) onde a mobilidade cicloviária se encontra no estágio de política pública definitivamente assumida como modo de transporte efetivo, conclui-se serem necessários investimentos mais pesados em infraestrutura de circulação cicloviária segregada (ciclovias e ciclofaixas) como forma de encorajar a população a utilizar a bicicleta como modo de transporte . Enquanto Berlim conta com $750 \mathrm{Km}$, Amsterdã com $400 \mathrm{Km}$ e Bogotá com $359 \mathrm{Km}^{90}$ de ciclovias e ciclofaixas, a somatória destas tipologias cicloviárias na capital paulistana chegam aos $63 \mathrm{Km}$ no momento da conclusão deste trabalho.

Entretanto ciclovias e ciclofaixas, apesar de serem economicamente mais vantajosas em relação às demais infraestruturas viárias, têm um custo significativo com as necessárias obras, sinalização e urbanização. Também implicam no comprometimento de espaços viários atualmente destinados aos automóveis circularem e estacionarem. Assim sacrificar estes espaços para cedê-los à circulação ciclística é atualmente complicado e impopular, uma vez ainda há forte resistência ao abandono do uso do automóvel, tido ainda por muitos, como a melhor forma de se transportar na cidade. Por este motivo a prefeitura teme restringir ainda mais a circulação dos modos de transporte motorizados individuais já que parte do espaço viário está sendo priorizado ao

90 Estruturas cicloviárias em cidades do mundo - www.mobilize.org.br 
transporte coletivo, através do programa de implantação dos corredores e faixas exclusivas de ônibus, principal diretriz da política de transporte da atual administração municipal.

A alternativa pelas econômicas ciclorrotas, modalidade de infraestrutura cicloviária em que a bicicleta circula juntamente com o fluxo veicular motorizado, é caracterizada apenas por sinalização viária sem haver necessidade de obras. Entretanto esta modalidade não é a mais adequada para quem for inexperiente em pedalar por não oferecer a mesma segurança das ciclovias e ciclofaixas . Para ser totalmente segura seria necessário um tratamento de desenho viário e de regulamentação de velocidade que garantissem a redução dos atuais níveis de velocidade veicular para $30 \mathrm{Km} / \mathrm{h}$ no máximo. Entretanto os valores de velocidade regulamentados para a malha viária paulistana e inseridos nos hábitos e comportamento dos motoristas, somados à dificuldade em se efetivar os necessários mecanismos de controle e fiscalização, inviabilizam a adoção e a aplicação destes padrões, desencorajando muitos potenciais ciclistas.

Já as ciclofaixas operacionais de lazer não contam como infraestrutura cicloviária de apoio ao transporte cotidiano, mas sua presença é importante como ferramenta para consolidar na população a ideia do uso da bicicleta no deslocamento diário. Ao mesmo tempo em que propicia um laboratório para teste de futuras intervenções cicloviárias proporciona um ambiente de treinamento a todos os usuários da via em relação à convivência com o tráfego ciclístico.

Outro aspecto motivo de reflexão nesta tese abordou sobre a viabilidade de uma rede de transporte cicloviário substituir uma rede transporte público coletivo, seja ela sobre trilhos ou pneus no caso de uma metrópole com a dimensão e as características de São Paulo. Concluiu-se pela inviabilidade por vários motivos, dentre os quais a não correspondência entre a caracterização das viagens cotidianas por transporte coletivo e os padrões usuais das viagens por bicicleta, conforme apontado pela última Pesquisa de Origem e Destino do Metrô, realizada em 2007. Portanto a vocação da viagem cotidiana da bicicleta deve sim explorar seu potencial como modo de transporte integrado aos atuais sistemas e atender aos deslocamentos complementares. Para tanto devem ser 
garantidos em terminais e estações a existência de bicicletários ou serviços de bicicletas compartilhadas ou bicicletas públicas, complementados por infraestruturas de acesso e circulação ciclística seguras: ciclovias, ciclofaixas ou ciclorrotas em vias acalmadas, considerando sempre as características dos locais e do veículo bicicleta.

Junto com a consolidação de uma rede física de infraestrutura cicloviária este trabalho registrou também a urgente necessidade de serem providenciadas ações políticas de curto e médio prazos quanto às leis de trânsito e programas de educação de trânsito e cidadania, como forma de prepararo do usuário da via para inserção segura e responsável da bicicleta no trânsito. Mais especificamente são elas relacionadas à urgente revisão do Código de Trânsito Brasileiro quanto aos direitos e deveres dos ciclistas, adaptações no processo de habilitação do motorista, cursos de capacitação e direção defensiva para ciclistas, campanhas educativas e ações de planejamento e fiscalização.

A partir das considerações que compõem este posfacio, pode-se concluir que os aspectos registrados ao longo da tese em questão apontam a efetiva adoção da bicicleta como modo de transporte cotidiano no município de São Paulo. Eles caracterizam um processo em crescimento irreversível já captado e absorvido pelo poder público e sociedade. Esta sensibilização manifestada por ações e políticas voltadas à consolidação de uma rede de transporte ciclístico, acaba por gerar uma malha cicloviária ainda tímida e desarticulada, produzida sem planejamento e em resposta à pressão exercida por setores organizados da sociedade, nem sempre representativos da maioria do público usuário. Mesmo assim as ações políticas resultantes deste processo tem como mérito uma mudança de paradigma ao afirmarem o uso utilitário da bicicleta como componente da mobilidade paulistana, descolando-a definitivamente das funções de lazer e esporte que exclusivamente moldaram as políticas anteriores. São fruto de decisões tomadas pelo poder público, algumas delas envolvendo a sociedade, mas sempre com vistas tornar São Paulo uma cidade melhor para se viver. 
ANEXO I

LEGISLAÇÃO CICLOVIÁRIA 


\section{Explicações para consulta do Anexo I}

O Anexo I contém os textos totais ou parciais das leis analisadas e mencionadas nesta tese, no que se refere à Mobilidade Cicloviária. Encontra-se dividido pelas legislações federal, estadual e municipal e seu objetivo é fornecer informações preliminares para facilitar uma consulta mais detalhada.

Encontra-se dividido da seguinte forma:

1. Legislação Federal:

1.1. Código de Trânsito Brasileiro - Lei Federal $n^{\circ} 9.503$, de 23 de setembro de 1997;

1.2. Lei Federal da Mobilidade Urbana $n^{\circ} 12.587$, de 3 de janeiro de 2012.

2. Legislação Estadual:

2.1. Lei $\mathrm{N}^{\circ} 10.095$, de 26 de novembro de 1998 , dispõe sobre o Plano Cicloviário do Estado de São Paulo e dá outras providências;

2.2. Lei $n^{\circ} 12.286$, de 22 de fevereiro de 2006, institui a política de incentivo ao uso da bicicleta no Estado de São Paulo;

3. Legislação Municipal:

3.1. Lei 10.907 de 18 de dezembro de 1990, ou Lei das Ciclovias em Novas Avenidas: dispõe sobre a destinação de espaços para ciclovias no Município de São Paulo, e dá outras providências;

3.2. Lei 11.005 de 18 de junho de 1991 - Bicicletários nos Parques Municipais: dispõe sobre local para guarda de bicicletas e triciclos nos parques municipais;

3.3. Decreto $\mathrm{n}^{\circ} \mathbf{3 4 . 8 5 4}$ de 03/02/1995 - Ciclofaixas em praças e parques públicos: Regulamenta a lei $n^{\circ} 10.908$, de 18 de dezembro de 1990, e dá outras providências; 
3.4. Lei N. 11.784, de 26 de maio de 1995 - Ciclofaixas nos finais de semana e feriados nas vias que dão acesso aos parques e áreas de lazer: Altera a redação do artigo $2^{\circ}$ da Lei n. 10.907, de 18 de dezembro de 1990, e dá outras providências

3.5. Decreto 35.860 de 6 de fevereiro de 1996 - Estacionamento para bicicletas em parques municipais: regulamenta a Lei 11.005 de 18 de junho de 1991 e dá outras providências;

3.6. Lei $\mathrm{n}^{\circ}$ 12.044, de 17 de abril de 1996 - Criação da Semana da Bicicleta: institui em âmbito do Município de São Paulo a criação da Semana da Bicicleta e dá outras providências;

3.7. Decreto $\mathrm{n}^{\circ} \mathbf{3 7 . 6 5 1}$, de 25 de setembro de 1998 - Regulamenta a Lei $\mathrm{n}^{\circ}$ 12.044, de 17 de abril de 1996, que institui a "Semana da Bicicleta", e dá outras providências;

3.8. Lei Municipal 13.430 / 02 -Lei que instituo o Plano Diretor : Artigos relativos à ciclovias;

3.9. Lei $N^{\circ} 13.995$, de 10 de junho de 2005 - Obrigatoriedade da criação de bicicletários em local de grande afluxo de público

3.10. Portaria 1918/06 - PREF - Criação do Grupo Pro Ciclista;

3.11. Lei $\mathrm{n}^{\circ}$ 14.223, de 26 de setembro de 2006 -Lei Cidade Limpa Dispõe sobre a ordenação dos elementos que compõem a paisagem urbana do Município de São Paulo - artigos relativos à infraestrutura cicloviária;

3.12. Lei $n^{\circ}$ 14.266, de 6 de fevereiro de 2007 - Criação do Sistema Cicloviário - SICLO - Dispõe sobre a criação do Sistema Cicloviário no Município de São Paulo e dá outras providências;

3.13. Decreto $n^{\circ} \mathbf{5 0 . 7 0 8}$, de 2 de julho de 2009 - Mudança da coordenação do Grupo Pró Ciclista: da SVMA - Secretaria Municipal do Verde e Meio Ambiente para a SMT - Secretaria Municipal de Transportes;

3.14. Decreto $n^{\circ}$ 51.622, de 12 de julho de 2010 - Cria a Rota Turística Márcia Prado;

3.15. Decreto $\mathrm{N}^{\circ} \mathbf{5 1 . 6 6 5}$, de 26 de julho de 2010 - Obrigatoriedade de seguro contra roubo de moto e bicicleta em estacionamentos; 
3.16. Lei $\mathrm{n}^{0} 15.649$, de 5 de dezembro de 2012 - Obrigatoriedade de previsão de vagas para estacionamento de bicicletas em edificações sob a legislação de Polos Geradores;

3.17. Decreto $n^{\circ} 53.942$, de 28 de maio de 2013 - Decreto que regulamenta a Lei $n^{\circ} 15.649 / 12$ - estacionamento para bicicletas em polos geradores;

3.18. Outras leis e decretos municipais instituídos entre 1994 e 1999 referentes à indicações de ciclovias em bairros e parques municipais.

\section{LEGISLAÇÃO FEDERAL}

1.1. Código de Trânsito Brasileiro Lei Federal $n^{\circ} 9.503$, de 23 de setembro de 1997

\section{CAPÍTULO I \\ DISPOSIÇÕES PRELIMINARES}

Art. $1^{\circ} 0$ trânsito de qualquer natureza nas vias terrestres do território nacional, abertas à circulação, rege-se por este Código.

$\S 1^{\circ}$ Considera-se trânsito a utilização das vias por pessoas, veículos e animais, isolados ou em grupos, conduzidos ou não, para fins de circulação, parada, estacionamento e operação de carga ou descarga.

$\S 2^{\circ} \mathrm{O}$ trânsito, em condições seguras, é um direito de todos e dever dos órgãos e entidades componentes do Sistema Nacional de Trânsito, a estes cabendo, no âmbito das respectivas competências, adotar as medidas destinadas a assegurar esse direito.

$\S 3^{\circ}$ Os órgãos e entidades componentes do Sistema Nacional de Trânsito respondem, no âmbito das respectivas competências, objetivamente, por danos causados aos cidadãos em virtude de ação, omissão ou erro na execução e manutenção de programas, projetos e serviços que garantam o exercício do direito do trânsito seguro.

$\S 4^{\circ}$ (VETADO)

$\S 5^{\circ}$ Os órgãos e entidades de trânsito pertencentes ao Sistema Nacional de Trânsito darão prioridade em suas ações à defesa da vida, nela incluída a preservação da saúde e do meio-ambiente.

Art. $3^{\circ}$ As disposições deste Código são aplicáveis a qualquer veículo, bem como aos proprietários, condutores dos veículos nacionais ou estrangeiros e às pessoas nele expressamente mencionadas.

\section{CAPÍTULO II \\ DO SISTEMA NACIONAL DE TRÂNSITO}

Seção I

Disposições Gerais 
Art. $5^{\circ}$ O Sistema Nacional de Trânsito é o conjunto de órgãos e entidades da União, dos Estados, do Distrito Federal e dos Municípios que tem por finalidade o exercício das atividades de planejamento, administração, normatização, pesquisa, registro e licenciamento de veículos, formação, habilitação e reciclagem de condutores, educação, engenharia, operação do sistema viário, policiamento, fiscalização, julgamento de infrações e de recursos e aplicação de penalidades.

Art. 24. Compete aos órgãos e entidades executivos de trânsito dos Municípios, no âmbito de sua circunscrição:

I - cumprir e fazer cumprir a legislação e as normas de trânsito, no âmbito de suas atribuições;

II - planejar, projetar, regulamentar e operar o trânsito de veículos, de pedestres e de animais, e promover o desenvolvimento da circulação e da segurança de ciclistas;

XVII - registrar e licenciar, na forma da legislação, ciclomotores, veículos de tração e propulsão humana e de tração animal, fiscalizando, autuando, aplicando penalidades e arrecadando multas decorrentes de infrações;

XVIII - conceder autorização para conduzir veículos de propulsão humana e de tração animal;

\section{CAPÍTULO III \\ DAS NORMAS GERAIS DE CIRCULAÇÃO E CONDUTA}

Art. 27. Antes de colocar o veículo em circulação nas vias públicas, o condutor deverá verificar a existência e as boas condições de funcionamento dos equipamentos de uso obrigatório, bem como assegurar-se da existência de combustível suficiente para chegar ao local de destino.

Art. 28. O condutor deverá, a todo momento, ter domínio de seu veículo, dirigindo-o com atenção e cuidados indispensáveis à segurança do trânsito.

Art. 29. O trânsito de veículos nas vias terrestres abertas à circulação obedecerá às seguintes normas:

IV - quando uma pista de rolamento comportar várias faixas de circulação no mesmo sentido, são as da direita destinadas ao deslocamento dos veículos mais lentos e de maior porte, quando não houver faixa especial a eles destinada, e as da esquerda, destinadas à ultrapassagem e ao deslocamento dos veículos de maior velocidade;

$\S 2^{\circ}$ Respeitadas as normas de circulação e conduta estabelecidas neste artigo, em ordem decrescente, os veículos de maior porte serão sempre responsáveis pela segurança dos menores, os motorizados pelos não motorizados e, juntos, pela incolumidade dos pedestres.

Art. 38. Antes de entrar à direita ou à esquerda, em outra via ou em lotes lindeiros, o condutor deverá:

I - ao sair da via pelo lado direito, aproximar-se o máximo possível do bordo direito da pista e executar sua manobra no menor espaço possível;

II - ao sair da via pelo lado esquerdo, aproximar-se o máximo possível de seu eixo ou da linha divisória da pista, quando houver, caso se trate de uma pista com circulação nos dois sentidos, ou do bordo esquerdo, tratando-se de uma pista de um só sentido.

Parágrafo único. Durante a manobra de mudança de direção, o condutor deverá ceder passagem aos pedestres e ciclistas, aos veículos que transitem em sentido contrário pela pista da via da qual vai sair, respeitadas as normas de preferência de passagem. 
Art. 39. Nas vias urbanas, a operação de retorno deverá ser feita nos locais para isto determinados, quer por meio de sinalização, quer pela existência de locais apropriados, ou, ainda, em outros locais que ofereçam condições de segurança e fluidez, observadas as características da via, do veículo, das condições meteorológicas e da movimentação de pedestres e ciclistas.

Art. 58. Nas vias urbanas e nas rurais de pista dupla, a circulação de bicicletas deverá ocorrer, quando não houver ciclovia, ciclofaixa, ou acostamento, ou quando não for possível a utilização destes, nos bordos da pista de rolamento, no mesmo sentido de circulação regulamentado para a via, com preferência sobre os veículos automotores.

Parágrafo único. A autoridade de trânsito com circunscrição sobre a via poderá autorizar a circulação de bicicletas no sentido contrário ao fluxo dos veículos automotores, desde que dotado o trecho com ciclofaixa.

Art. 59. Desde que autorizado e devidamente sinalizado pelo órgão ou entidade com circunscrição sobre a via, será permitida a circulação de bicicletas nos passeios.

\section{CAPÍTULO IV \\ DOS PEDESTRES E CONDUTORES DE VEÍCULOS NÃO MOTORIZADOS}

Art. 68. É assegurada ao pedestre a utilização dos passeios ou passagens apropriadas das vias urbanas e dos acostamentos das vias rurais para circulação, podendo a autoridade competente permitir a utilização de parte da calçada para outros fins, desde que não seja prejudicial ao fluxo de pedestres.

$\S 1^{\circ} \mathrm{O}$ ciclista desmontado empurrando a bicicleta equipara-se ao pedestre em direitos e deveres.

\section{CAPÍTULO IX \\ DOS VEÍCULOS}

\section{Seção I}

Disposições Gerais

Art. 96. Os veículos classificam-se em:

I - quanto à tração:

a) automotor;

b) elétrico;

c) de propulsão humana;

d) de tração animal;

e) reboque ou semi-reboque;

II - quanto à espécie:

a) de passageiros:

1 - bicicleta;

2 - ciclomotor;

3 - motoneta;

4 - motocicleta;

5 - triciclo;

6 - quadriciclo;

7 - automóvel;

8 - microônibus;

9 - ônibus;

10 - bonde;

11 - reboque ou semi-reboque;

12 - charrete; 
Art. 105. São equipamentos obrigatórios dos veículos, entre outros a serem estabelecidos pelo CONTRAN

VI - para as bicicletas, a campainha, sinalização noturna dianteira, traseira, lateral e nos pedais, e espelho retrovisor do lado esquerdo.

$\S 1^{\circ}$ O CONTRAN disciplinará o uso dos equipamentos obrigatórios dos veículos e determinará suas especificações técnicas.

$\S 2^{\circ}$ Nenhum veículo poderá transitar com equipamento ou acessório proibido, sendo o infrator sujeito às penalidades e medidas administrativas previstas neste Código.

$\S 3^{\circ}$ Os fabricantes, os importadores, os montadores, os encarroçadores de veículos e os revendedores devem comercializar os seus veículos com os equipamentos obrigatórios definidos neste artigo, e com os demais estabelecidos pelo CONTRAN.

\section{Seção III}

\section{Da Identificação do Veículo}

Art. 115. O veículo será identificado externamente por meio de placas dianteira e traseira, sendo esta lacrada em sua estrutura, obedecidas as especificações e modelos estabelecidos pelo CONTRAN.

$\S 6^{\circ}$ Os veículos de duas ou três rodas são dispensados da placa dianteira.

\section{CAPÍTULO XIV \\ DA HABILITAÇÃO}

Art. 141. O processo de habilitação, as normas relativas à aprendizagem para conduzir veículos automotores e elétricos e à autorização para conduzir ciclomotores serão regulamentados pelo CONTRAN.

$\S 1^{\circ} \mathrm{A}$ autorização para conduzir veículos de propulsão humana e de tração animal ficará a cargo dos Municípios.

\section{CAPÍTULO XV \\ DAS INFRAÇÕES}

Art. 165. Dirigir sob a influência de álcool, em nível superior a seis decigramas por litro de sangue, ou de qualquer substância entorpecente ou que determine dependência física ou psíquica.

Infração - gravíssima;

Penalidade - multa (cinco vezes) e suspensão do direito de dirigir;

Medida administrativa - retenção do veículo até a apresentação de condutor habilitado e recolhimento do documento de habilitação.

Art. 170. Dirigir ameaçando os pedestres que estejam atravessando a via pública, ou os demais veículos:

Infração - gravíssima;

Penalidade - multa e suspensão do direito de dirigir;

Medida administrativa - retenção do veículo e recolhimento do documento de habilitação.

Art. 181. Estacionar o veículo:

VIII - no passeio ou sobre faixa destinada a pedestre, sobre ciclovia ou ciclofaixa, bem como nas ilhas, refúgios, ao lado ou sobre canteiros centrais, divisores de pista de rolamento, marcas de canalização, gramados ou jardim público:

Infração - grave;

Penalidade - multa; 
Art. 184. Transitar com o veículo:

I - na faixa ou pista da direita, regulamentada como de circulação exclusiva para determinado tipo de veículo, exceto para acesso a imóveis lindeiros ou conversões à direita:

Infração - leve;

Penalidade - multa;

Art. 193. Transitar com o veículo em calçadas, passeios, passarelas, ciclovias, ciclofaixas, ilhas, refúgios, ajardinamentos, canteiros centrais e divisores de pista de rolamento, acostamentos, marcas de canalização, gramados e jardins públicos:

Infração - gravíssima;

Penalidade - multa (três vezes).

Art. 196. Deixar de indicar com antecedência, mediante gesto regulamentar de braço ou luz indicadora de direção do veículo, o início da marcha, a realização da manobra de parar o veículo, a mudança de direção ou de faixa de circulação:

Infração - grave;

Penalidade - multa.

Art. 201. Deixar de guardar a distância lateral de um metro e cinqüenta centímetros ao passar ou ultrapassar bicicleta:

Infração - média;

Penalidade - multa.

Art. 204. Deixar de parar o veículo no acostamento à direita, para aguardar a oportunidade de cruzar a pista ou entrar à esquerda, onde não houver local apropriado para operação de retorno:

Infração - grave;

Penalidade - multa.

Art. 206. Executar operação de retorno:

I - em locais proibidos pela sinalização;

II - nas curvas, aclives, declives, pontes, viadutos e túneis;

III - passando por cima de calçada, passeio, ilhas, ajardinamento ou canteiros de divisões de pista de rolamento, refúgios e faixas de pedestres e nas de veículos não motorizados;

IV - nas interseções, entrando na contramão de direção da via transversal;

V - com prejuízo da livre circulação ou da segurança, ainda que em locais permitidos:

Infração - gravíssima;

Penalidade - multa.

Art. 214. Deixar de dar preferência de passagem a pedestre e a veículo não motorizado:

I - que se encontre na faixa a ele destinada; veículo;

II - que não haja concluído a travessia mesmo que ocorra sinal verde para o

III - portadores de deficiência física, crianças, idosos e gestantes:

Infração - gravíssima;

Penalidade - multa. destinada;

IV - quando houver iniciado a travessia mesmo que não haja sinalização a ele

V - que esteja atravessando a via transversal para onde se dirige o veículo: 
Infração - grave;

Penalidade - multa.

Art. 244. Conduzir motocicleta, motoneta e ciclomotor:

I - sem usar capacete de segurança com viseira ou óculos de proteção e vestuário de acordo com as normas e especificações aprovadas pelo CONTRAN;

II - transportando passageiro sem o capacete de segurança, na forma estabelecida no inciso anterior, ou fora do assento suplementar colocado atrás do condutor ou em carro lateral;

III - fazendo malabarismo ou equilibrando-se apenas em uma roda;

IV - com os faróis apagados;

V - transportando criança menor de sete anos ou que não tenha, nas circunstâncias, condições de cuidar de sua própria segurança:

Infração - gravíssima;

Penalidade - multa e suspensão do direito de dirigir;

Medida administrativa - Recolhimento do documento de habilitação;

$\mathrm{VI}$ - rebocando outro veículo;

VII - sem segurar o guidom com ambas as mãos, salvo eventualmente para indicação de manobras;

VIII - transportando carga incompatível com suas especificações:

Infração - média;

Penalidade - multa.

$\S 1^{\circ}$ Para ciclos aplica-se o disposto nos incisos III, VII e VIII, além de:

a) conduzir passageiro fora da garupa ou do assento especial a ele destinado;

b) transitar em vias de trânsito rápido ou rodovias, salvo onde houver acostamento ou faixas de rolamento próprias;

c) transportar crianças que não tenham, nas circunstâncias, condições de cuidar de sua própria segurança.

$\S 2^{\circ}$ Aplica-se aos ciclomotores o disposto na alínea $b$ do parágrafo anterior:

Infração - média;

Penalidade - multa.

Art. 246. Deixar de sinalizar qualquer obstáculo à livre circulação, à segurança de veículo e pedestres, tanto no leito da via terrestre como na calçada, ou obstaculizar a via indevidamente:

Infração - gravíssima;

Penalidade - multa, agravada em até cinco vezes, a critério da autoridade de trânsito, conforme o risco à segurança.

Parágrafo único. A penalidade será aplicada à pessoa física ou jurídica responsável pela obstrução, devendo a autoridade com circunscrição sobre a via providenciar a sinalização de emergência, às expensas do responsável, ou, se possível, promover a desobstrução.

Art. 247. Deixar de conduzir pelo bordo da pista de rolamento, em fila única, os veículos de tração ou propulsão humana e os de tração animal, sempre que não houver acostamento ou faixa a eles destinados:

Infração - média;

Penalidade - multa.

Art. 252. Dirigir o veículo:

I - com o braço do lado de fora;

II - transportando pessoas, animais ou volume à sua esquerda ou entre os braços e pernas; 
do trânsito;

III - com incapacidade física ou mental temporária que comprometa a segurança pedais;

IV - usando calçado que não se firme nos pés ou que comprometa a utilização dos

$\mathrm{V}$ - com apenas uma das mãos, exceto quando deva fazer sinais regulamentares de braço, mudar a marcha do veículo, ou acionar equipamentos e acessórios do veículo;

$\mathrm{VI}$ - utilizando-se de fones nos ouvidos conectados a aparelhagem sonora ou de telefone celular;

Infração - média;

Penalidade - multa.

Art. 255. Conduzir bicicleta em passeios onde não seja permitida a circulação desta, ou de forma agressiva, em desacordo com o disposto no parágrafo único do art. 59:

Infração - média;

Penalidade - multa;

Medida administrativa - remoção da bicicleta, mediante recibo para o pagamento da multa.

\section{ANEXO I \\ DOS CONCEITOS E DEFINIÇÕES}

Para efeito deste Código adotam-se as seguintes definições:

ACOSTAMENTO - parte da via diferenciada da pista de rolamento destinada à parada ou estacionamento de veículos, em caso de emergência, e à circulação de pedestres e bicicletas, quando não houver local apropriado para esse fim.

BICICLETA - veículo de propulsão humana, dotado de duas rodas, não sendo, para efeito deste Código, similar à motocicleta, motoneta e ciclomotor.

BICICLETÁRIO - local, na via ou fora dela, destinado ao estacionamento de bicicletas.

CALÇADA - parte da via, normalmente segregada e em nível diferente, não destinada à circulação de veículos, reservada ao trânsito de pedestres e, quando possível, à implantação de mobiliário urbano, sinalização, vegetação e outros fins.

CICLO - veículo de pelo menos duas rodas a propulsão humana.

CICLOFAIXA - parte da pista de rolamento destinada à circulação exclusiva de ciclos, delimitada por sinalização específica.

CICLOVIA - pista própria destinada à circulação de ciclos, separada fisicamente do tráfego comum.

PASSEIO - parte da calçada ou da pista de rolamento, neste último caso, separada por pintura ou elemento físico separador, livre de interferências, destinada à circulação exclusiva de pedestres e, excepcionalmente, de ciclistas.

\subsection{Lei Federal da Mobilidade Urbana $N^{\circ} 12.587$, DE 3 DE JANEIRO DE 2012.}

\section{Artigos relacionados ao Transporte Não Motorizado}

Institui as diretrizes da Política Nacional de Mobilidade Urbana; revoga dispositivos dos Decretos-Leis nos 3.326, de 3 de junho de 1941, e 5.405, de 13 de abril de 1943, da Consolidação das Leis do Trabalho (CLT), aprovada pelo Decreto-Lei no 5.452 , de 
$1^{\circ}$ de maio de 1943, e das Leis $\mathrm{n}^{\text {os }} 5.917$, de 10 de setembro de 1973, e 6.261 , de 14 de novembro de 1975; e dá outras providências.

A PRESIDENTA DA REPÚBLICA Faço saber que o Congresso Nacional decreta e eu sanciono a seguinte Lei:

\section{CAPÍTULO I}

\section{DISPOSIÇÕES GERAIS}

Art. $1^{\circ}$ A Política Nacional de Mobilidade Urbana é instrumento da política de desenvolvimento urbano de que tratam o inciso XX do art. 21 e o art. $182 \mathrm{da}$ Constituição Federal, objetivando a integração entre os diferentes modos de transporte e a melhoria da acessibilidade e mobilidade das pessoas e cargas no território do Município.

Parágrafo único. A Política Nacional a que se refere o caput deve atender ao

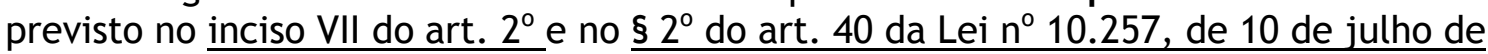
2001 (Estatuto da Cidade).

Art. $2^{\circ}$ A Política Nacional de Mobilidade Urbana tem por objetivo contribuir para o acesso universal à cidade, o fomento e a concretização das condições que contribuam para a efetivação dos princípios, objetivos e diretrizes da política de desenvolvimento urbano, por meio do planejamento e da gestão democrática do Sistema Nacional de Mobilidade Urbana.

Art. $3^{\circ}$ O Sistema Nacional de Mobilidade Urbana é o conjunto organizado e coordenado dos modos de transporte, de serviços e de infraestruturas que garante os deslocamentos de pessoas e cargas no território do Município.

$\S 1^{0}$ São modos de transporte urbano:

I - motorizados; e

II - não motorizados.

§ $2^{\circ}$ Os serviços de transporte urbano são classificados:

I - quanto ao objeto:

a) de passageiros;

b) de cargas;

II - quanto à característica do serviço:

a) coletivo;

b) individual;

III - quanto à natureza do serviço:

a) público;

b) privado.

$\S 3^{\circ}$ São infraestruturas de mobilidade urbana:

I - vias e demais logradouros públicos, inclusive metroferrovias, hidrovias e ciclovias;

II - estacionamentos;

III - terminais, estações e demais conexões;

IV - pontos para embarque e desembarque de passageiros e cargas;

V - sinalização viária e de trânsito;

VI - equipamentos e instalações; e

VII - instrumentos de controle, fiscalização, arrecadação de taxas e tarifas e difusão de informações. 


\section{Seção I}

Das Definições

Art. 4- Para os fins desta Lei, considera-se:

I - transporte urbano: conjunto dos modos e serviços de transporte público e privado utilizados para o deslocamento de pessoas e cargas nas cidades integrantes da Política Nacional de Mobilidade Urbana;

II - mobilidade urbana: condição em que se realizam os deslocamentos de pessoas e cargas no espaço urbano;

III - acessibilidade: facilidade disponibilizada às pessoas que possibilite a todos autonomia nos deslocamentos desejados, respeitando-se a legislação em vigor;

IV - modos de transporte motorizado: modalidades que se utilizam de veículos automotores;

V - modos de transporte não motorizado: modalidades que se utilizam do esforço humano ou tração animal;

VI - transporte público coletivo: serviço público de transporte de passageiros acessível a toda a população mediante pagamento individualizado, com itinerários e preços fixados pelo poder público;

VII - transporte privado coletivo: serviço de transporte de passageiros não aberto ao público para a realização de viagens com características operacionais exclusivas para cada linha e demanda;

VIII - transporte público individual: serviço remunerado de transporte de passageiros aberto ao público, por intermédio de veículos de aluguel, para a realização de viagens individualizadas;

IX - transporte urbano de cargas: serviço de transporte de bens, animais ou mercadorias;

$X$ - transporte motorizado privado: meio motorizado de transporte de passageiros utilizado para a realização de viagens individualizadas por intermédio de veículos particulares;

XI - transporte público coletivo intermunicipal de caráter urbano: serviço de transporte público coletivo entre Municípios que tenham contiguidade nos seus perímetros urbanos;

XII - transporte público coletivo interestadual de caráter urbano: serviço de transporte público coletivo entre Municípios de diferentes Estados que mantenham contiguidade nos seus perímetros urbanos; e

XIII - transporte público coletivo internacional de caráter urbano: serviço de transporte coletivo entre Municípios localizados em regiões de fronteira cujas cidades são definidas como cidades gêmeas. 
Dos Princípios, Diretrizes e Objetivos da Política Nacional de Mobilidade Urbana

Art. 5 A Política Nacional de Mobilidade Urbana está fundamentada nos seguintes princípios:

I - acessibilidade universal;

II - desenvolvimento sustentável das cidades, nas dimensões socioeconômicas e ambientais;

III - equidade no acesso dos cidadãos ao transporte público coletivo; urbano;

IV - eficiência, eficácia e efetividade na prestação dos serviços de transporte

V - gestão democrática e controle social do planejamento e avaliação da Política Nacional de Mobilidade Urbana;

$\mathrm{VI}$ - segurança nos deslocamentos das pessoas;

VII - justa distribuição dos benefícios e ônus decorrentes do uso dos diferentes modos e serviços;

VIII - equidade no uso do espaço público de circulação, vias e logradouros; e

IX - eficiência, eficácia e efetividade na circulação urbana.

Art. 6ำ A Política Nacional de Mobilidade Urbana é orientada pelas seguintes diretrizes:

I - integração com a política de desenvolvimento urbano e respectivas políticas setoriais de habitação, saneamento básico, planejamento e gestão do uso do solo no âmbito dos entes federativos;

II - prioridade dos modos de transportes não motorizados sobre os motorizados e dos serviços de transporte público coletivo sobre o transporte individual motorizado;

III - integração entre os modos e serviços de transporte urbano;

IV - mitigação dos custos ambientais, sociais e econômicos dos deslocamentos de pessoas e cargas na cidade;

$\mathrm{V}$ - incentivo ao desenvolvimento científico-tecnológico e ao uso de energias renováveis e menos poluentes;

VI - priorização de projetos de transporte público coletivo estruturadores do território e indutores do desenvolvimento urbano integrado; e

VII - integração entre as cidades gêmeas localizadas na faixa de fronteira com outros países sobre a linha divisória internacional.

Art. $7^{\circ}$ A Política Nacional de Mobilidade Urbana possui os seguintes objetivos: 
I - reduzir as desigualdades e promover a inclusão social;

II - promover o acesso aos serviços básicos e equipamentos sociais;

III - proporcionar melhoria nas condições urbanas da população no que se refere à acessibilidade e à mobilidade;

IV - promover o desenvolvimento sustentável com a mitigação dos custos ambientais e socioeconômicos dos deslocamentos de pessoas e cargas nas cidades; e

V - consolidar a gestão democrática como instrumento e garantia da construção contínua do aprimoramento da mobilidade urbana.

\section{CAPÍTULO II}

\section{DAS DIRETRIZES PARA A REGULAÇÃO DOS SERVIÇOS DE TRANSPORTE PÚBLICO COLETIVO}

Art. $8^{\circ}$ A política tarifária do serviço de transporte público coletivo é orientada pelas seguintes diretrizes:

I - promoção da equidade no acesso aos serviços;

II - melhoria da eficiência e da eficácia na prestação dos serviços;

III - ser instrumento da política de ocupação equilibrada da cidade de acordo com o plano diretor municipal, regional e metropolitano; serviços;

IV - contribuição dos beneficiários diretos e indiretos para custeio da operação dos

V - simplicidade na compreensão, transparência da estrutura tarifária para o usuário e publicidade do processo de revisão;

VI - modicidade da tarifa para o usuário;

VII - integração física, tarifária e operacional dos diferentes modos e das redes de transporte público e privado nas cidades;

VIII - articulação interinstitucional dos órgãos gestores dos entes federativos por meio de consórcios públicos; e

IX - estabelecimento e publicidade de parâmetros de qualidade e quantidade na prestação dos serviços de transporte público coletivo.

Art. 18. São atribuições dos Municípios:

I - planejar, executar e avaliar a política de mobilidade urbana, bem como promover a regulamentação dos serviços de transporte urbano;

II - prestar, direta, indiretamente ou por gestão associada, os serviços de transporte público coletivo urbano, que têm caráter essencial; 
III - capacitar pessoas e desenvolver as instituições vinculadas à política de mobilidade urbana do Município; e

IV - (VETADO).

Art. 19. Aplicam-se ao Distrito Federal, no que couber, as atribuições previstas para os Estados e os Municípios, nos termos dos arts. 17 e 18.

Art. 20. O exercício das atribuições previstas neste Capítulo subordinar-se-á, em cada ente federativo, às normas fixadas pelas respectivas leis de diretrizes orçamentárias, às efetivas disponibilidades asseguradas pelas suas leis orçamentárias anuais e aos imperativos da Lei Complementar $\mathrm{n}^{\circ} 101$, de 4 de maio de 2000.

\section{CAPÍTULO V}

\section{DAS DIRETRIZES PARA O PLANEJAMENTO E GESTÃO DOS SISTEMAS DE MOBILIDADE URBANA}

Art. 21. O planejamento, a gestão e a avaliação dos sistemas de mobilidade deverão contemplar:

I - a identificação clara e transparente dos objetivos de curto, médio e longo prazo;

II - a identificação dos meios financeiros e institucionais que assegurem sua implantação e execução;

III - a formulação e implantação dos mecanismos de monitoramento e avaliação sistemáticos e permanentes dos objetivos estabelecidos; e

IV - a definição das metas de atendimento e universalização da oferta de transporte público coletivo, monitorados por indicadores preestabelecidos.

Art. 22. Consideram-se atribuições mínimas dos órgãos gestores dos entes federativos incumbidos respectivamente do planejamento e gestão do sistema de mobilidade urbana:

I - planejar e coordenar os diferentes modos e serviços, observados os princípios e diretrizes desta Lei;

II - avaliar e fiscalizar os serviços e monitorar desempenhos, garantindo a consecução das metas de universalização e de qualidade;

III - implantar a política tarifária;

IV - dispor sobre itinerários, frequências e padrão de qualidade dos serviços;

V - estimular a eficácia e a eficiência dos serviços de transporte público coletivo;

VI - garantir os direitos e observar as responsabilidades dos usuários; e 
VII - combater o transporte ilegal de passageiros.

Art. 23. Os entes federativos poderão utilizar, dentre outros instrumentos de gestão do sistema de transporte e da mobilidade urbana, os seguintes:

I - restrição e controle de acesso e circulação, permanente ou temporário, de veículos motorizados em locais e horários predeterminados;

II - estipulação de padrões de emissão de poluentes para locais e horários determinados, podendo condicionar o acesso e a circulação aos espaços urbanos sob controle;

III - aplicação de tributos sobre modos e serviços de transporte urbano pela utilização da infraestrutura urbana, visando a desestimular o uso de determinados modos e serviços de mobilidade, vinculando-se a receita à aplicação exclusiva em infraestrutura urbana destinada ao transporte público coletivo e ao transporte não motorizado e no financiamento do subsídio público da tarifa de transporte público, na forma da lei;

IV - dedicação de espaço exclusivo nas vias públicas para os serviços de transporte público coletivo e modos de transporte não motorizados;

V - estabelecimento da política de estacionamentos de uso público e privado, com e sem pagamento pela sua utilização, como parte integrante da Política Nacional de Mobilidade Urbana;

$\mathrm{VI}$ - controle do uso e operação da infraestrutura viária destinada à circulação e operação do transporte de carga, concedendo prioridades ou restrições;

VII - monitoramento e controle das emissões dos gases de efeito local e de efeito estufa dos modos de transporte motorizado, facultando a restrição de acesso a determinadas vias em razão da criticidade dos índices de emissões de poluição;

VIII - convênios para o combate ao transporte ilegal de passageiros; e

IX - convênio para o transporte coletivo urbano internacional nas cidades definidas como cidades gêmeas nas regiões de fronteira do Brasil com outros países, observado 0 art. 178 da Constituição Federal.

Art. 24. O Plano de Mobilidade Urbana é o instrumento de efetivação da Política Nacional de Mobilidade Urbana e deverá contemplar os princípios, os objetivos e as diretrizes desta Lei, bem como:

I - os serviços de transporte público coletivo;

II - a circulação viária;

III - as infraestruturas do sistema de mobilidade urbana;

IV - a acessibilidade para pessoas com deficiência e restrição de mobilidade;

V - a integração dos modos de transporte público e destes com os privados e os não motorizados; 

viária;

VI - a operação e o disciplinamento do transporte de carga na infraestrutura

VII - os polos geradores de viagens;

VIII - as áreas de estacionamentos públicos e privados, gratuitos ou onerosos;

IX - as áreas e horários de acesso e circulação restrita ou controlada;

$\mathrm{X}$ - os mecanismos e instrumentos de financiamento do transporte público coletivo e da infraestrutura de mobilidade urbana; e

XI - a sistemática de avaliação, revisão e atualização periódica do Plano de Mobilidade Urbana em prazo não superior a 10 (dez) anos.

§ 1ํㅡㄹ Municípios acima de 20.000 (vinte mil) habitantes e em todos os demais obrigados, na forma da lei, à elaboração do plano diretor, deverá ser elaborado o Plano de Mobilidade Urbana, integrado e compatível com os respectivos planos diretores ou neles inserido.

§ $2^{\circ}$ Nos Municípios sem sistema de transporte público coletivo ou individual, o Plano de Mobilidade Urbana deverá ter o foco no transporte não motorizado e no planejamento da infraestrutura urbana destinada aos deslocamentos a pé e por bicicleta, de acordo com a legislação vigente.

§ 3ํ O Plano de Mobilidade Urbana deverá ser integrado ao plano diretor municipal, existente ou em elaboração, no prazo máximo de 3 (três) anos da vigência desta Lei.

$\S 4^{\circ}$ Os Municípios que não tenham elaborado o Plano de Mobilidade Urbana na data de promulgação desta Lei terão o prazo máximo de 3 (três) anos de sua vigência para elaborá-lo. Findo o prazo, ficam impedidos de receber recursos orçamentários federais destinados à mobilidade urbana até que atendam à exigência desta Lei.

\section{CAPÍTULO VI}

\section{DOS INSTRUMENTOS DE APOIO À MOBILIDADE URBANA}

Art. 25. O Poder Executivo da União, o dos Estados, o do Distrito Federal e o dos Municípios, segundo suas possibilidades orçamentárias e financeiras e observados os princípios e diretrizes desta Lei, farão constar dos respectivos projetos de planos plurianuais e de leis de diretrizes orçamentárias as ações programáticas e instrumentos de apoio que serão utilizados, em cada período, para o aprimoramento dos sistemas de mobilidade urbana e melhoria da qualidade dos serviços.

Parágrafo único. A indicação das ações e dos instrumentos de apoio a que se refere o caput será acompanhada, sempre que possível, da fixação de critérios e condições para o acesso aos recursos financeiros e às outras formas de benefícios que sejam estabelecidos. 
CAPÍTULO VII

\section{DISPOSIÇÕES FINAIS}

Art. 26. Esta Lei se aplica, no que couber, ao planejamento, controle, fiscalização e operação dos serviços de transporte público coletivo intermunicipal, interestadual e internacional de caráter urbano.

Art. 27. (VETADO).

Art. 28. Esta Lei entra em vigor 100 (cem) dias após a data de sua publicação.

Brasília, 3 de janeiro de 2012; 191ํ da Independência e 124ํ da República.

\section{LEGISLAÇÃO ESTADUAL SOBRE BICICLETA}

\subsection{Lei $N^{\circ} 10.095$, de 26 de novembro de 1998}

Site da Assembléia Legislativa de SP www.al.sp.gov.br/repositorio/legislacao/lei/.../lei-10095-26.11.1998.html (Projeto de Lei $n^{\circ}$ 918, de 1995, do Deputado Walter Feldman - PSDB)

Publicação: Diário Oficial v.108, n.225, 27/11/98

Gestão: Mário Covas

Revogações:

Alteraçõ̃es:

Órgão:

Categoria: Transportes

Termos Descritores:

INFRAESTRUTURA DE TRANSPORTE; CICLOVIAS;

\section{Transportes}

Dispõe sobre o Plano Cicloviário do Estado de São Paulo e dá outras providências.

O PRESIDENTE DA ASSEMBLÉIA LEGISLATIVA:

Faço saber que a Assembléia Legislativa decreta e eu promulgo, nos termos do artigo 28, § $8^{\circ}$, da Constituição do Estado, a seguinte lei:

Artigo $1 .^{\circ}$ - A presente lei disciplina a implementação de infra-estrutura para o trânsito de veículos de propulsão humana nas estradas estaduais e nos terrenos marginais às linhas férreas.

Artigo $2 .^{\circ}$ - Constituem objetivos do Plano Cicloviário do Estado de São Paulo:

I - introduzir critérios de planejamento para implantação de ciclovias ou ciclo-faixas em rodovias e nos terrenos marginais às linhas férreas;

II - compatibilizar e promover a circulação intermunicipal;

III - facilitar a circulação nos espaços habitáveis e áreas adjacentes ou circundantes;

IV - conscientizar a população sobre o uso conjunto e a circulação por trechos de estradas de tráfego compartilhado;

$\mathrm{V}$ - promover a integração dos transportes terrestres; 
VI - introduzir medidas de segurança de circulação;

VII - reduzir a poluição ambiental e minimizar seus efeitos negativos.

Artigo $3 .^{\circ}$ - Considera-se ciclo-faixa, para os efeitos desta lei "a faixa especial de trânsito, destinada à circulação de bicicletas, pintada ou demarcada na pista de rolamento ou no acostamento das estradas".

Artigo $4 .^{\circ}$ - Considera-se ciclovia, para os efeitos desta lei "a pista de rolamento destinada ao uso de bicicletas, paralela ao leito carroçável das estradas e dele separada por obstrução física".

$\S 1^{\circ}$ - A separação deverá ser total.

$\S 2^{\circ}$ - A separação, sempre que possível, deverá ser executada considerando como alinhamento o sistema de drenagem.

$\S 3^{\circ}$ - Ocorrendo impossibilidade técnica de aplicação do disposto no parágrafo anterior, deverão ser instalados obstáculos, tais como gradis (defensas) ou cercas vivas.

Artigo $5 .^{\circ}$ - Todos os projetos de construção de estradas estaduais deverão incluir a criação de ciclovias:

I - em trechos urbanos ou conturbados;

II - em trechos rurais, para servir de acesso a instalações industriais, comerciais ou institucionais.

Artigo $6 .^{\circ}$ - Todos os projetos de construção de estradas, em fase de implantação, deverão ser revistos e adaptados aos termos desta lei.

Artigo 7. - 0 Poder Executivo regulamentará e coordenará um programa especial de implantação de ciclovias ou ciclo-faixas nas estradas atualmente existentes.

Parágrafo único - 0 programa especial a que se refere este artigo será regulamentado por decreto, no prazo de 180 (cento e oitenta) dias, contados da data de publicação da presente lei.

Artigo $8 .^{\circ}$ - Deverão ser implantadas ciclovias ou ciclo-faixas nos terrenos marginais às linhas férreas:

I - em trechos urbanos;

II - em trechos de interesse turístico;

III - em trechos de acesso a instalações industriais, comerciais e institucionais.

Artigo 9. - Todos os projetos de obras públicas de transposição de obstáculos, naturais ou artificiais, deverão incluir ciclovia ou ciclo-faixa.

Parágrafo único - Constituem obstáculos, dentre outros, rios, lagos, ferrovias e acessos a estradas secundárias ou vicinais.

Artigo 10 - 0 disposto no artigo anterior deverá ser implantado nas obras já concluídas, respeitadas as normas técnicas aplicáveis e a disponibilidade de recursos.

Parágrafo único - O Executivo regulamentará por decreto o disposto neste artigo.

Artigo 11 - Será colocada sinalização específica ao longo das ciclovias e ciclo-faixas.

Parágrafo único - O Poder Executivo poderá proibir a circulação de veículos de propulsão humana em locais considerados perigosos por não se adequarem às normas técnicas de segurança.

Artigo 12 - O Departamento Estadual de Trânsito apresentará, anualmente, relatório de estatística de acidentes pessoais, com morte ou lesões corporais, bem como dos danos patrimoniais.

Parágrafo único - O relatório de estatística deverá ser publicado no Diário Oficial do Estado.

Artigo 13 - O Conselho Estadual de Trânsito e o Departamento Estadual de Trânsito deverão promover campanhas educativas, tendo por público alvo pedestres $\mathrm{e}$ condutores de veículos, motorizados ou não, visando divulgar o uso adequado de espaços físicos compartilhados.

Artigo 14 - A passagem de ciclistas e pedestres pelos postos de pedágio deverá ter área própria e de circulação segura.

Artigo 15 - Fica expressamente vedada a cobrança de taxa de pedágio aos ciclistas.

Artigo 16 - Aplica-se, no que couber, o disposto na legislação federal vigente. 
Artigo 17 - As despesas decorrentes da aplicação da presente lei correrão à conta das dotações orçamentárias próprias, suplementadas se necessário.

Artigo 18 - O Poder Executivo expedirá decreto regulamentador no prazo de 180 (cento e oitenta) dias, contados da data da publicação desta lei.

Artigo 19 - Esta lei entrará em vigor na data de sua publicação, revogadas as disposições em contrário, em especial o artigo 10 da Lei $n^{\circ} 784$, de 30 de agosto de 1950 e a Lei ${ }^{\circ}$ 1.208 , de 15 de dezembro de 1976.

Assembléia Legislativa do Estado de São Paulo, aos 26 de novembro de 1998.

a) PAULO KOBAYASHI - Presidente

Publicada na Secretaria da Assembléia Legislativa do Estado de São Paulo, aos 26 de novembro de 1998.

\subsection{Lei $\mathrm{n}^{\circ} 12.286$, de 22 de fevereiro de 2006}

Site: http://www.4shared.com/office/z00k_u9p/sp-estadual_lei_12286-06__cri.html

(Projeto de lei n²20/2005, do Deputado Afonso Lobato - PV)

Institui a politica de incentivo ao uso da bicicleta no Estado de São Paulo.

\section{O GOVERNADOR DO ESTADO DE SÃO PAULO:}

Faço saber que a Assembléia Legislativa decreta e eu promulgo a seguinte lei:

Artigo $1^{\circ}$ - Fica instituída a Política de Incentivo ao Uso da Bicicleta no âmbito do Estado de São Paulo.

Parágrafo único - O incentivo ao uso da bicicleta como forma de mobilidade urbana tem por objetivo proporcionar o acesso amplo e democrático ao espaço urbano, por meio da priorização dos modos de transporte:

1 - coletivo;

2 - não-motorizado.

Artigo $2^{\circ}$ - A implementação da política de que trata esta lei garantir:

I - o desenvolvimento de atividades relacionadas com o sistema de mobilidade cicloviária e de pedestres;

II - a promoção de ações e projetos em favor de ciclistas, pedestres e usuários de cadeiras de rodas, a fim de melhorar as condições para o deslocamento;

III - a melhoria da qualidade de vida nas cidades do Estado, por intermédio de ações que favoreçam o caminhar e o pedalar;

IV - a eliminação de barreiras urbanísticas aos ciclistas e usuários de cadeiras de rodas;

V - a implementação de infra-estrutura cicloviária urbana, como ciclovias, ciclofaixas, faixas compartilhadas, bicicletários e sinalização específica;

VI - a integração da bicicleta ao sistema de transporte público existente;

VII - a promoção de campanhas educativas voltadas para o uso da bicicleta.

Artigo $3^{\circ}$ - São objetivos desta lei, entre outros: 
I - possibilitar o aumento da consciência dos efeitos indesejáveis da utilização do automóvel nas locomoções urbanas;

II - possibilitar a redução do uso do automóvel nas viagens de curtas distâncias e o aumento de sua ocupação;

III - estimular o uso da bicicleta como meio de transporte alternativo;

IV - criar atitude favorável aos deslocamentos cicloviários;

$\mathrm{V}$ - promover a bicicleta como modalidade de deslocamento urbano eficiente e saudável;

$\mathrm{VI}$ - estimular o planejamento espacial e territorial com base nos deslocamentos cicloviários e de usuários de cadeiras de rodas;

VII - estimular o desenvolvimento de projetos e obras de infra-estrutura cicloviária;

VIII - implementar melhorias de infra-estrutura que favoreçam os deslocamentos cicloviários;

IX - incentivar o associativismo entre os ciclistas e usuários dessa modalidade de transporte;

$\mathrm{X}$ - estimular a conexão entre cidades, por meio de rotas seguras para o deslocamento cicloviário, voltadas para o turismo e o lazer.

Artigo $4^{0}$ - As ações de implementação da política cicloviária e do uso da bicicleta serão coordenadas pelo Poder Executivo, garantida a participação de usuários, representantes da sociedade civil organizada e profissionais com atuação nessa área.

Artigo $5^{\circ}$ - 0 Poder Executivo instituirá campanha publicitária de educação para implementação da política cicloviária, especialmente no que concerne à aplicação de normas de uso da bicicleta.

Artigo $6^{\circ}$ - As despesas decorrentes da execução desta lei correrão à conta de dotações orçamentárias próprias, suplementadas se necessário.

Artigo $7^{\circ}$ - Esta lei entra em vigor na data de sua publicação.

Palácio dos Bandeirantes, aos 22 de fevereiro de 2006.

Geraldo Alckmin

Dario Rais Lopes

Secretário dos Transportes

José Goldemberg

Secretário do Meio Ambiente

Jurandir Fernando Ribeiro Fernandes

Secretário dos Transportes Metropolitanos

Arnaldo Madeira

Secretário-Chefe da Casa Civil 
Publicada na Assessoria Técnico-Legislativa, aos 22 de fevereiro de 2006.

Publicado em : D.O.E em 23/02/2006, Secção I - pág. 01

Atualizado em: 24/02/2006 10:57

Lei $\mathrm{n}^{\circ} 12.286$, de 22 de fevereiro de 2006

\section{LEGISLAÇÃO MUNICIPAL SOBRE BICICLETA}

Obs: As leis municipais foram obtidas através do Portal da Prefeitura de São Paulowww.prefeitura.sp.gov.br com detalhamento somente da legislação de interesse para este trabalho.

Em decorrência do extenso material relativo à legislação municipal foram expostas de forma detalhadas as leis e decretos mais importantes para o histórico e a definição das políticas cicloviárias municipais, ficando os demais apenas mencionados.

\subsection{Lei 10.907 de 18 de dezembro de 1990 - Ciclovias nas Novas Avenidas}

Projeto de Lei $n^{\circ}$ 382/89 - Vereador Walter Feldman

Dispõe sobre a destinação de espaços para ciclovias no

Município de São Paulo, e dá outras providências

Eduardo Matarazzo Suplicy, Presidente da Câmara Municipal de São Paulo.

faz saber que a Câmara Municipal de São Paulo, nos termos do $\xi 7^{\circ}$ do artigo $42 \mathrm{da}$ Lei Orgânica do Município de São Paulo promulga a seguinte Lei :

Art. 10 - Fica estabelecido para as construgões de avenidas, no Município de São Paulo, a partir da publicação desta Lei, da obrigatoriedade de demarcação de espagos para diclovias.

Parágrafo único. Entende-se por ciclovias, espagos demarcados no leito carroçável de avenidas, exclusivas para veículos que não contenham tração motora.

Art. $2^{\mathbf{0}}$ - Fica estabelecido nas atuais avenidas, de acesso aos parques públicos do muniápio, demarcação de cido-faixas, destinadas aos usuários nos sábados e domingos. 
Art. $3^{0}$ - As despesas decorrentes desta Lei, correrão por conta de dotações orçamentárias próprias, suplementadas se necessário.

Art. $4^{\circ}$ - Esta Lei entrará em vigor na data de sua publicação, revogadas as disposições em contrário.

\title{
3.2.Lei 11.005 - de 18 de junho de 1991 - Bicicletários nos Parques Municipais (Projeto de Lei 316/89 do Vereador Marcos Mendonça)
}

\author{
Dispõe sobre local para guarda de bicicletas e \\ triciclos nos parques municipais
}

Luiza Erundina de Sousa, Prefeita do Município de São Paulo, usando das atribuições que lhe são conferidas por lei.

Faz saber que a Câmara Municipal, em sessão de 29 de maio de 1991, decretou e eu promulgo a seguinte Lei:

Art. $1^{0}$ Nos parques públicos municipais onde haja grande freqüência de cidistas, havendo área disponivel e mediante prévio estudo, ficam criados locais para guarda de bicidetas e triciclos de seus usuários.

Art. $2^{\mathbf{0}}$ Para o cumprimento do disposto no artigo anterior, poderá a iniciativa privada, mediante contrato com a Prefeitura, executar e explorar $\propto$ referido estacionamentos, desde que não haja ônus financeiro para a Municipalidade, em troca da concessão de espaço para exploração de publicidade.

Art. $3^{0}$ Para a guarda das bicicletas e tricidos nos locais referidos no artigo $1^{\circ}$, poderá ser cobrada estadia de seus usuários.

Art. $4^{\circ}$ Caberá ao Executivo a regulamentação da presente Lei, dentro de 40 (quarenta) dias a contar de sua publicação.

Art. $5^{\circ}$ Esta Lei entrará em vigor na data de sua publicação, revogadas as disposições em contrário. 


\subsection{Decreto $n^{\circ} 34.854$ de 03/02/1995 - Ciclofaixas em praças e parques públicos}

Regulamenta a lei $n^{\circ} 10.908$, de 18 de dezembro de 1990, e dá outras providências

PAULO MALUF, Prefeito do Município de São Paulo, usando das atribuiç̧̃̃es que 1 he são conferidas por $1 \mathrm{ei}$,

DECRETA:

Art. $1^{\circ}$-As praças e os parques públicos Municipais, que comportem a circulação de bicicletas, serão dotados de ciclo-faixas, voltadas para o uso exclusivo de veículos que não possuam tração motora.

Parágrafo único -A demarcação, no leito carroçável, de ciclo-faixa., deverá atender as normas do Código Nacional de Transito - CNT, podendo variar suas dimensões em função dos obstáculos naturais existentes no terreno.

Art. $2^{\circ}$ - disposições deste decreto estendem-se aos jardins do sistema viário, nos canteiros centrais de avenidas existentes, desde que apresentem largura igual ou superior a 3 (três) vezes à destinada à ciclo-faixa.

Art. $3^{\circ}$ - As ciclo-faixas poderão ser demarcadas nos passeios, desde que tecnicamente demonstrada a viabilidade de uso compartilhado no mesmo espaço por pedestres e ciclista. .

Art. $4^{\circ}$ - As ciclo-faixas serão dotadas de sinalização, vertical, horizontal e semafórica, nos termos da normatização técnica em vigor .

Art $.5^{\circ}$ - A responsabilidade pela manutenção e sinalização de ciclofaixas nos arques públicos Municipais será da Secretaria Municipal do Verde e do Meio Ambiente -SVMA, e, em praças e jardins do sistema viário, será da Secretaria das Administrações Regionais - SAR.

Art . $6^{\circ}$ - Serão destinados espaços para estacionamento de bicicletas, preferentemente em locais sombreados, por ocasião da implantação de ciclo-faixas.

Art. $7^{\circ}$-A Secretaria Municipal do Verde do Meio Ambiente. -SVMA desenvolverá programas educativos, direcionados a orientação e conscientização dos usuários das praças e parques públicos quanto às vantagens de uso compartilhado de espaços entre pedestres e ciclistas.

Art. $8^{\circ}$ - Este decreto entrará em vigor na da data de sua publicação, revogadas as disposições em contrário. 
3.4. LEI N. 11.784, DE 26 DE MAIO DE 1995 - Ciclofaixas nos finais de semana e feriados nas vias que dão acesso aos parques e áreas de lazer

(Projeto de Lei n. 662/93 da Vereadora Ana Martins)

Altera a redação do artigo $2^{\circ}$ da Lei n. 10.907, de 18 de dezembro de 1990, e dá outras providências

Miguel Colasuonno, Presidente da Câmara Municipal de São Paulo, faz saber que a Câmara Municipal de São Paulo, de acordo com o $\$ 7^{\circ}$ do artigo 42 da Lei Orgânica do Município de São Paulo, promulga a seguinte Lei:

Art. $1^{\circ} \mathrm{O}$ artigo $2^{\circ}$ da Lei $\mathrm{n}^{\circ} 10.907$, de 18 de dezembro de 1990, passa a vigorar com a seguinte redação:

“Art. $2^{\circ}$ Fica estabelecida nas atuais avenidas de acesso aos parques e grandes áreas de lazer do Município de São Paulo a demarcação de ciclofaixas destinadas aos usuários nos sábados, domingos e feriados.

Parágrafo único - O Executivo fará ampla campanha de divulgação pelos meios de comunicação para estimular o uso das bicicletas nas avenidas demarcadas."

Art. $2^{\circ} 0$ Executivo Municipal realizará estudos técnicos para a implementação gradativa, em todos os dias e horários, de faixas especiais, em avenidas cujo tráfego não ofereça riscos.

Art. $3^{\circ}$ As despesas com a execução desta Lei correrão por conta das dotações orçamentárias próprias, suplementadas se necessário.

Art. $4^{\circ}$ Esta Lei entrará em vigor na data da publicação, revogadas as disposições em contrário. 


\subsection{Decreto 35.860 de 6 de ferereiro de 1996 - Estacionamento para bicicletas em parques municipais}

Regulamenta a Lei 11.005 de 18 de junho de 1991 e dá outras providências.

PAULO MALUF, Prefeito do Município de São Paulo, usando das atribuições que the são conferi das por lei,

\section{DECRETA:}

Art. $1^{\circ}$ - Os parques públicos municipais com grande freqüência de ciclistas, que tenham área disponível e mediante prévio estudo. serão dotados de estacionamento para bicicletas e triciclos, obedecidas as disposiçôes deste decreto.

Parágrafo único - Nos parques tombados, protegidos por legislação municipal de preservação, ou enquadrados como Zona de Uso Z8-200, a instalação dos equipamentos de que trata o "caput" deste artigo deverá ser submetida à prévia aprovação do Conselho Municipal de Preservação do Patrimônio Histórico, Cultural e Ambiental da Cidade de São Paulo - CONPRESP ou da Secretaria Municipal do Planejamento - SEMPLA.

Art. $2^{\circ}$-Nos parques onde se admita a circulação de bicicletas e triciclos. os estacionamentos serão implantados em locais de fácil visão, nas imediações de equipamentos e serviços, tais como:

I-Sanitários;

II-Restaurantes;

III -Lanchonetes;

IV -Sorveterias;

$\mathrm{V}$-Portôes de acesso;

VI -Prédio da administração do parque :

VII -Quadra de jogos:

VIII -Play-grounds ou áreas infantis.

Art. $3^{\circ}$ - Nos parques onde não e admita a circulação de bicicletas e triciclos, os estacionamentos serão intemos. devendo sua localização ser fixada pelo Departamento de Parques e Areas Verdes-DEPAVE, obedecidas as diretrizes gerais fixadas pela Secretaria Municipal do Verde e do Meio Ambiente - SVMA. 


\subsection{Lei $n^{\circ} 12.044$, de 17 de abril de 1996 - Criação da Semana da Bicicleta}

(Projeto de Lei $\mathrm{n}^{\circ} 1356 / 95$ do Vereador Aurélio Nomura)

Institui, no âmbito do Município de São Paulo, a Semana da Bicicleta, e da outras providências.

PAULO MALUF, Prefeito do Muniápio de São Paulo, usando das atribuições que the são conferidas por lei.

Faz saber que, nos termos do disposto no inciso I do artigo $84 \mathrm{da}$ Resdução $n^{0}$ 02/91, a Câmara Municipal de São Paulo, decretou e promulgo a seguinte lei:

ART, $1^{0}$ - Fica instituida, no âmbito do Município de São Paulo, a Semana da Bicicleta, a ser comemorada, anualmente, na segunda semana de julho.

Art. $2^{\mathbf{0}}$ - $O$ evento ora instituido passa a integrar $o$ calendáric Oficial da Cidade de São Paulo.

Art. $3^{0}$ - O Poder Executivo regulamentará esta lei no prazo de 60 (sessenta) dias, a contar da data de sua publicação.

Art. $4^{0}$ - As despesas, decorrentes da execução da presente lei correrão por conta das dotạóes orçamentário próprias, suplementadas se necessário.

Art. $5^{0}$ - Esta lei entrará em vigor na data de sua publicação, revogadas as disposições em contrário.

\subsection{DECRETO $\mathrm{N}^{\circ}$ 37.651, DE 25 DE SETEMBRO DE 1998}

Regulamenta a Lei $\mathrm{n}^{\circ} 12.044$, de 17 de abril de 1996, que institui a "Semana da Bicicleta", e dá outras providências.

CELSO PITTA, Prefeito do Município de São Paulo, usando das atribuições que the são conferidas por lei, DECRETA: 
Art. $1^{\circ}$ - A "Semana da Bicicleta", instituída pela Lei $\mathrm{n}^{\circ} 12.044$, de 17 de abril de 1996, será comemorada anualmente a partir do primeiro domingo, a contar do dia 2 de julho, até o domingo subseqüente

Art. $2^{\circ}$ - Durante a comemoração de que trata o artigo anterior serão realizados eventos ciclísticos, com duração mínima de 5 horas, nas áreas das Administrações Regionais.

§ $1^{\circ}$ - A coordenação dos eventos de que trata o "caput" deste artigo caberá à Secretaria Municipal de Esportes, Lazer e Recreação - SEME, que poderá, para tanto, constituir Equipe Intersecretarial.

§ $2^{\circ}$ - A Secretaria das Administrações Regionais - SAR poderá planejar mais de um evento em Bairros e em Conjuntos Habitacionais, levando em conta as condições viárias e submetendo as propostas à equipe de que trata o parágrafo anterior.

Art $3^{\circ}$ - A Secretaria das Administrações Regionais - SAR, em consonância com a Secretaria Municipal de Transportes - SMT, caberá determinar as ruas a serem interditadas, parcial ou integralmente, para a realização dos eventos ciclísticos.

Art $4^{\circ}$ - A Secretaria Municipal de Transportes - SMT, pelo Departamento de Transportes Públicos - DTP e pelo Departamento do Sistema Viário - DSV caberá:

I -Estabelecer, juntamente com a Companhia de Engenharia de Tráfego - CET e com o Comando de Policiamento de Trânsito - CPTran, a sinalização e o policiamento relacionado à realização dos eventos, visando à interdição, aos desvios, à segurança e à orientação de tráfego no sistema viário local e regional afetado;

II -Veicular, nos órgãos de imprensa; em colaboração com o Comando de Policiamento de Trânsito - CPTran e as respectivas Assessorias de Comunicação, durante a "Semana da Bicicleta", noticias diárias relacionadas com a segurança, direitos e deveres dos ciclistas na circulação urbana.

Art. $5^{\circ}$ - A Secretaria Municipal do Verde e do Meio Ambiente - SVMA caberá:

I - Pelo Departamento de Planejamento e Educação Ambiental - DEAPLA: orientar os órgãos municipais referidos nos artigos anteriores sobre as normas complementares e específicas pertinentes à política de combate da poluição automotiva, por meio da promoção do uso da bicicleta no transporte urbano.

II- Pelo Departamento de Parques e Áreas Verdes - DEPAVE: expedir normas às Administrações dos Parques Municipais, incumbindo-as de organizar em cada unidade e em conjunto com Associações de Usuários, quando houver, eventos ciclísticos nos domingos que abrem e fecham a "Semana da Bicicleta". 
Art $6^{\circ}$ - A Secretaria Municipal da Saúde - SMS caberá divulgar os benefícios e os cuidados necessários ao uso da bicicleta

Art. $7^{\circ}$ - As despesas decorrentes deste decreto correrão por conta das dotações orçamentário próprias, suplementadas se necessário.

\subsection{Lei Municipal 13.430 / 02 - Plano Diretor (Artigo relativos à ciclovias)}

$\S 2^{\circ}$ - Rotas de ciclismo somente poderão se utilizar das vias da Rede Viária Estrutural quando estas forem de nível 2 e 3, em dias, trechos e horários a serem determinados em função da menor demanda de tráfego.

Art. 110 - As vias da Rede Viária Estrutural constituem o suporte da Rede Estrutural de Transportes prevista no $\S 1^{\circ}$ do artigo 174 da Lei Orgânica do Município.

$\S 1^{\circ}$ - As vias estruturais, independentemente de suas características físicas, estão classificadas em três níveis:

I - $1^{\circ}$ Nível - aquelas utilizadas como ligação da Capital com os demais municípios do Estado de São Paulo e com os demais estados da Federação;

II - $2^{\circ}$ Nível - aquelas, não incluídas no nível anterior, utilizadas como ligação com os municípios da Região Metropolitana e com as vias do $1^{\circ}$ nível;

III - $3^{\circ}$ Nível - aquelas, não incluídas nos níveis anteriores, utilizadas como ligações internas no Município.

$\S 2^{\circ}$ - As demais vias do Município, não estruturais, são as que coletam e distribuem o tráfego internamente aos bairros e ficam classificadas em quatro tipos:

1 - coletoras;

2 - vias locais;

3 - ciclovias;

4 - vias de pedestres.

PUBLICADO DOC 06/12/2012, p. 1 c. 1 


\subsection{LEI N 13.995, DE 10 DE JUNHO DE 2005 - Obrigatoriedade da criação de bicicletários em local de grande afluxo de público}

(Projeto de Lei $\mathrm{n}^{\circ}$ 161/05, do Vereador Adolfo Quintas - PSDB)

Dispõe sobre a criação de estacionamento de bicicletas em locais abertos à freqüência de público e dá outras providências.

JOSÉ SERRA, Prefeito do Município de São Paulo, no uso das atribuições que the são conferidas por lei, faz saber que a Câmara Municipal, em sessão de 11 de maio de 2005, decretou e eu promulgo a seguinte lei:

Art. $1^{\circ}$ Fica estabelecida a obrigatoriedade de criação de estacionamentos para bicicletas em locais de grande afluxo de público, em todo Município de São Paulo.

Art. $2^{\circ}$ Para fins desta lei entende-se como locais públicos de grande afluxo os seguinte estabelecimentos:

a) órgãos públicos municipais;

b) parques;

c) shopping centers;

d) supermercados;

e) instituições de ensinos públicos e privados;

f) agências bancárias;

g) igrejas e locais de cultos religiosos;

h) hospitais;

i) instalações desportivas;

j) museus e outros equipamentos de natureza culturais (teatro, cinemas, casas de cultura, etc.); e

k) indústrias.

Art. $3^{\circ} \mathrm{A}$ segurança dos ciclistas e dos pedestres deverá ser determinante para a definição do local na implantação do estacionamento de bicicletas.

Art. $4^{\circ}$ Os estacionamentos de bicicletas poderão ser de dois tipos, a saber:

I - bicicletários - local destinado ao estacionamento de bicicletas, por período de longa duração, podendo ser público ou privado;

II - paraciclo - local em via pública, destinado ao estacionamento de bicicletas, por período de curta e média duração. 
Art. $5^{\circ} 0$ Executivo regulamentará esta lei no prazo de 60 (sessenta) dias.

Art. $6^{\circ}$ As despesas decorrentes da execução desta lei correrão por conta de dotações orçamentárias próprias, suplementadas se necessário.

Art. $7^{\circ}$ Esta lei entrará em vigor na data de sua publicação, revogadas as disposições em contrário.

PREFEITURA DO MUNICÍPIO DE SÃO PAULO, aos 10 de junho de $2005,452^{\circ}$ da fundação de São Paulo.

JOSÉ SERRA, PREFEITO

FREDERICO VICTOR MOREIRA BUSSINGER, Secretário Municipal de Transportes

WALTER MEYER FELDMAN, Secretário Municipal de Coordenação das Subprefeituras

FRANCISCO VIDAL LUNA, Secretário Municipal de Planejamento

Publicada na Secretaria do Governo Municipal, em 10 de junho de 2005.

\subsection{PORTARIA 1918/06 - PREF - Criação do Grupo Pro Ciclista DE 18 DE MAIO DE 2006}

GILBERTO KASSAB, Prefeito do Município de São Paulo, usando das atribuições que the são conferidas por lei, e,

CONSIDERANDO a necessidade de fomentar o uso da bicicleta como meio de transporte não poluente, de baixo custo, e como alternativa para o incremento da acessibilidade e da mobilidade da população, e

CONSIDERANDO as conclusões alcançadas no Relatório de Grupo de Trabalho Interinstitucional para Estudar o Fomento do Uso da Bicicleta como Meio de Transporte Não Motorizado e Instrumento de Melhoria Ambiental, com Indicação de Áreas para Intervenção Piloto, o Relatório do GT-Bicicleta,

RESOLVE:

I - Fica criado o Grupo Executivo da Prefeitura do Município de São Paulo para Melhoramentos Cicloviários - Pró-Ciclista, composto por:

a) Secretaria Municipal do Verde e do Meio Ambiente - SVMA, a quem compete a articulação geral das instituições envolvidas;

b) Secretaria Municipal de Transportes - SMT, a quem compete propor a diretriz técnica geral;

c) Companhia de Engenharia de Tráfego - CET, a quem compete prestar a assessoria técnica sobre gerenciamento de tráfego;

d) São Paulo Transporte S/A - SPTrans, a quem compete prestar a assessoria técnica para a conexão intermodal, bem como para a implantação de infraestrutura cicloviária associada aos corredores de ônibus; 
e) Secretaria de Infra-Estrutura Urbana e Obras - SIURB, a quem compete a contratação de projetos e obras de implantação de infraestrutura cicloviária;

f) Secretaria Municipal de Coordenação das Subprefeituras - SMSP, a quem compete a manutenção da infraestrutura cicloviária, bem como colaborar para sua implantação;

g) Secretaria Municipal de Esportes, Lazer e Recreação - SEME, a quem compete colaborar para a difusão da prática do uso seguro da bicicleta, bem como os modos de adequada condução desse veículo.

I.1. - O Pró-Ciclista será composto pelos seguintes membros:

Secretaria Municipal do Verde e do Meio Ambiente

ANA MARIA HOFFMANN / LAURA LUCIA VIEIRA CENEVIVA

Secretaria Municipal de Transportes

AYRTON CAMARGO E SILVA

Secretaria de Infra-estrutura Urbana e Obras

ALESSANDRO AUGUSTO DARDIN

Secretaria Municipal de Coordenação das Subprefeituras

FABIO TAKADA

Secretaria Municipal de Esportes, Lazer e Recreação

CARLOS PAULINO JUNIOR

Companhia de Engenharia de Tráfego

DAPHNE SAVOY / MARIA ERMELINA MALATESTA

São Paulo Transporte S/A

SUZANA LEITE NOGUEIRA / PEDRO DI MASE

I.2. - O Pró-Ciclista será coordenado pela funcionária LAURA LUCIA VIEIRA CENEVIVA, de SVMA.

I.3. - O Pró-Ciclista chamará, para cada intervenção a ser estudada, um representante da Subprefeitura atingida, que, para o seu território, terá atribuições similares às de SMSP.

I.4. - Se necessário para a consecução de suas atribuições, o Pró-Ciclista poderá solicitar a colaboração de qualquer outra instituição.

II - O Pró-Ciclista terá as seguintes atribuições:

a) identificar oportunidades para o fomento ao uso da bicicleta no Município de São Paulo, observadas as normas de trânsito vigentes;

b) articular os diversos órgãos públicos da administração direta e indireta da Prefeitura do Município de São Paulo, entre si ou com outras instituições, para estudar e implantar melhoramentos cicloviários e para fomentar o uso da bicicleta;

c) manifestar-se sobre questões que envolvam a implantação de melhoramentos cicloviários no Município de São Paulo;

d) colaborar para a construção do conhecimento relativo ao uso da bicicleta em meio urbano, de modo a poder treinar e capacitar a administração pública para este modo de transporte, bem como colaborar para a promoção da educação para a convivência entre os modos.

III - O Pró-Ciclista pautará seus estudos e ações pelas seguintes diretrizes: 
a) segurança;

b) coerência de percursos;

c) conexão intermodal;

d) atratividade para os ciclistas;

e) competitividade perante outros modos;

f) conforto;

g) melhoria ambiental.

IV - As despesas decorrentes desta Portaria correrão por conta das dotações orçamentárias próprias, suplementadas se necessário.

V - Esta Portaria entrará em vigor na data de sua publicação, revogadas as disposições em contrário.

PREFEITURA DO MUNICÍPIO DE SÃO PAULO, aos 18 de maio de 2006, 453 da fundação de São Paulo.

GILBERTO KASSAB, Prefeito

\subsection{LEI N 14.223, DE 26 DE SETEMBRO DE 2006 -Lei Cidade Limpa) -} Artigos relativos à infraestrutura cicloviária

(Projeto de Lei $n^{\circ} 379 / 06$, do Executivo, aprovado na forma de Substitutivo do Legislativo)

Dispõe sobre a ordenação dos elementos que compõem a paisagem urbana do Município de São Paulo.

GILBERTO KASSAB, Prefeito do Município de São Paulo, no uso das atribuições que the são conferidas por lei, faz saber que a Câmara Municipal, em sessão de 26 de setembro de 2006, decretou e eu promulgo a seguinte lei:

\section{CAPÍTULO I}

DOS OBJETIVOS, DIRETRIZES, ESTRATÉGIAS E DEFINIÇÕES

Art. $1^{\circ}$. Esta lei dispõe sobre a ordenação dos elementos que compõem a paisagem urbana, visíveis a partir de logradouro público no território do Município de São Paulo.

Art. $2^{\circ}$. Para fins de aplicação desta lei, considera-se paisagem urbana o espaço aéreo e a superfície externa de qualquer elemento natural ou construído, tais como água, fauna, flora, construções, edifícios, anteparos, superfícies aparentes de equipamentos de infra-estrutura, de segurança e de veículos automotores, anúncios de qualquer natureza, elementos de sinalização urbana, equipamentos de informação e comodidade pública e logradouros públicos, visíveis por qualquer observador situado em áreas de uso comum do povo. 
Art. $3^{\circ}$. Constituem objetivos da ordenação da paisagem do Município de São Paulo o atendimento ao interesse público em consonância com os direitos fundamentais da pessoa humana e as necessidades de conforto ambiental, com a melhoria da qualidade de vida urbana, assegurando, dentre outros, os seguintes:

I - o bem-estar estético, cultural e ambiental da população;

II - a segurança das edificações e da população;

III - a valorização do ambiente natural e construído;

IV - a segurança, a fluidez e o conforto nos deslocamentos de veículos e pedestres;

V - a percepção e a compreensão dos elementos referenciais da paisagem;

VI - a preservação da memória cultural;

VII - a preservação e a visualização das características peculiares dos logradouros e das fachadas;

VIII - a preservação e a visualização dos elementos naturais tomados em seu conjunto e em suas peculiaridades ambientais nativas;

IX - o fácil acesso e utilização das funções e serviços de interesse coletivo nas vias e logradouros;

X - o fácil e rápido acesso aos serviços de emergência, tais como bombeiros, ambulâncias e polícia;

$X I$ - o equilíbrio de interesses dos diversos agentes atuantes na cidade para a promoção da melhoria da paisagem do Município.

Art. $4^{\circ}$. Constituem diretrizes a serem observadas na colocação dos elementos que compõem a paisagem urbana:

I - o livre acesso de pessoas e bens à infra-estrutura urbana;

II - a priorização da sinalização de interesse público com vistas a não confundir motoristas na condução de veículos e garantir a livre e segura locomoção de pedestres;

III - o combate à poluição visual, bem como à degradação ambiental;

IV - a proteção, preservação e recuperação do patrimônio cultural, histórico, artístico, paisagístico, de consagração popular, bem como do meio ambiente natural ou construído da cidade;

V - a compatibilização das modalidades de anúncios com os locais onde possam ser veiculados, nos termos desta lei;

VI - a implantação de sistema de fiscalização efetivo, ágil, moderno, planejado e permanente.

Art. $5^{\circ}$. As estratégias para a implantação da política da paisagem urbana são as 
seguintes:

I - a elaboração de normas e programas específicos para os distintos setores da Cidade, considerando a diversidade da paisagem nas várias regiões que a compõem;

II - o disciplinamento dos elementos presentes nas áreas públicas, considerando as normas de ocupação das áreas privadas e a volumetria das edificações que, no conjunto, são formadoras da paisagem urbana;

III - a criação de novos padrões, mais restritivos, de comunicação institucional, informativa ou indicativa;

IV - a adoção de parâmetros de dimensões, posicionamento, quantidade e interferência mais adequados à sinalização de trânsito, aos elementos construídos e à vegetação, considerando a capacidade de suporte da região;

V - o estabelecimento de normas e diretrizes para a implantação dos elementos componentes da paisagem urbana e a correspondente veiculação de publicidade;

VI - a criação de mecanismos eficazes de fiscalização sobre as diversas intervenções na paisagem urbana.

Art. $6^{\circ}$. Para os efeitos de aplicação desta lei, ficam estabelecidas as seguintes definições:

I - anúncio: qualquer veículo de comunicação visual presente na paisagem visível do logradouro público, composto de área de exposição e estrutura, podendo ser:

a) anúncio indicativo: aquele que visa apenas identificar, no próprio local da atividade, os estabelecimentos e/ou profissionais que dele fazem uso;

b) anúncio publicitário: aquele destinado à veiculação de publicidade, instalado fora do local onde se exerce a atividade;

c) anúncio especial: aquele que possui características específicas, com finalidade cultural, eleitoral, educativa ou imobiliária, nos termos do disposto no art. 19 desta lei;

II - área de exposição do anúncio: a área que compõe cada face da mensagem do anúncio, devendo, caso haja dificuldade de determinação da superfície de exposição, ser considerada a área do menor quadrilátero regular que contenha o anúncio;

III - área livre de imóvel edificado: a área descoberta existente entre a edificação e qualquer divisa do imóvel que a contém;

IV - área total do anúncio: a soma das áreas de todas as superfícies de exposição do anúncio, expressa em metros quadrados;

V - bem de uso comum: aquele destinado à utilização do povo, tais como as áreas verdes e institucionais, as vias e logradouros públicos, e outros;

$\mathrm{VI}$ - bem de valor cultural: aquele de interesse paisagístico, cultural, turístico, arquitetônico, ambiental ou de consagração popular, público ou privado, composto pelas áreas, edificações, monumentos, parques e bens tombados pela União, Estado e Município, e suas áreas envoltórias; 
VII - espaço de utilização pública: a parcela do espaço urbano passível de uso e fruição pela população;

VIII - mobiliário urbano é o conjunto de elementos que podem ocupar o espaço público, implantados, direta ou indiretamente, pela Administração Municipal, com as seguintes funções urbanísticas:

a) circulação e transportes;

c) ornamentação da paisagem e ambientação urbana;

c) descanso e lazer;

d) serviços de utilidade pública;

e) comunicação e publicidade;

f) atividade comercial;

g) acessórios à infra-estrutura;

IX - fachada: qualquer das faces externas de uma edificação principal ou complementar, tais como torres, caixas d'água, chaminés ou similares;

X - imóvel: o lote, público ou privado, edificado ou não, assim definido:

a) imóvel edificado: aquele ocupado total ou parcialmente com edificação permanente;

b) imóvel não-edificado: aquele não ocupado ou ocupado com edificação transitória, em que não se exerçam atividades nos termos da legislação de uso e ocupação do solo;

XI - lote: a parcela de terreno resultante de loteamento, desmembramento ou desdobro, contida em uma quadra com, pelo menos, uma divisa lindeira a via de circulação oficial;

XII - testada ou alinhamento: a linha divisória entre o imóvel de propriedade particular ou pública e o logradouro ou via pública.

Art. $7^{\circ}$. Para os fins desta lei, não são considerados anúncios:

I - os nomes, símbolos, entalhes, relevos ou logotipos, incorporados à fachada por meio de aberturas ou gravados nas paredes, sem aplicação ou afixação, integrantes de projeto aprovado das edificações;

II - os logotipos ou logomarcas de postos de abastecimento e serviços, quando veiculados nos equipamentos próprios do mobiliário obrigatório, como bombas, densímetros e similares;

III - as denominações de prédios e condomínios;

IV - os que contenham referências que indiquem lotação, capacidade e os que recomendem cautela ou indiquem perigo, desde que sem qualquer legenda, dístico ou desenho de valor publicitário;

V - os que contenham mensagens obrigatórias por legislação federal, estadual ou 
municipal;

$\mathrm{VI}$ - os que contenham mensagens indicativas de cooperação com o Poder Público Municipal, Estadual ou Federal;

VII - os que contenham mensagens indicativas de órgãos da Administração Direta;

VIII - os que contenham indicação de monitoramento de empresas de segurança com área máxima de $0,04 \mathrm{~m}^{2}$ (quatro decímetros quadrados);

IX - aqueles instalados em áreas de proteção ambiental que contenham mensagens institucionais com patrocínio;

$\mathrm{X}$ - os que contenham as bandeiras dos cartões de crédito aceitos nos estabelecimentos comerciais, desde que não ultrapassem a área total de $0,09 \mathrm{~m}^{2}$ (nove decímetros quadrados);

XI - os "banners" ou pôsteres indicativos dos eventos culturais que serão exibidos na própria edificação, para museu ou teatro, desde que não ultrapassem $10 \%$ (dez por cento) da área total de todas as fachadas;

XII - a denominação de hotéis ou a sua logomarca, quando inseridas ao longo da fachada das edificações onde é exercida a atividade, devendo o projeto ser aprovado pela Comissão de Proteção à Paisagem Urbana - CPPU;

XIII - a identificação das empresas nos veículos automotores utilizados para a realização de seus serviços.

\subsection{LEI N 14.266, DE 6 DE FEVEREIRO DE 2007 - Criação do Sistema Cicloviário - SICLO}

(Projeto de Lei $\mathrm{n}^{\circ}$ 599/05, do Vereador Chico Macena - PT)

Dispõe sobre a criação do Sistema Cicloviário no Município de São Paulo e dá outras providências.

GILBERTO KASSAB, Prefeito do Município de São Paulo, no uso das atribuições que the são conferidas por lei, faz saber que a Câmara Municipal, em sessão de 26 de dezembro de 2006, decretou e eu promulgo a seguinte lei:

Art. $1^{\circ}$ Fica criado o Sistema Cicloviário do Município de São Paulo, como incentivo ao uso de bicicletas para o transporte na cidade de São Paulo, contribuindo para o desenvolvimento da mobilidade sustentável.

Parágrafo único. 0 transporte por bicicletas deve ser incentivado em áreas apropriadas e abordado como modo de transporte para as atividades do cotidiano, devendo ser considerado modal efetivo na mobilidade da população.

Art. $2^{\circ}$ O Sistema Cicloviário do Município de São Paulo será formado por: 
I - rede viária para o transporte por bicicletas, formada por ciclovias, ciclofaixas, faixas compartilhadas e rotas operacionais de ciclismo;

II - locais específicos para estacionamento: bicicletários e paraciclos.

Art. $3^{\circ}$ O Sistema Cicloviário do Município de São Paulo deverá:

I - articular o transporte por bicicleta com o Sistema Integrado de Transporte de Passageiros - SITP, viabilizando os deslocamentos com segurança, eficiência e conforto para o ciclista;

II - implementar infra-estrutura para o trânsito de bicicletas e introduzir critérios de planejamento para implantação de ciclovias ou ciclofaixas nos trechos de rodovias em zonas urbanizadas, nas vias públicas, nos terrenos marginais às linhas férreas, nas margens de cursos d'água, nos parques e em outros espaços naturais;

III - implantar trajetos cicloviários onde os desejos de viagem sejam expressivos para a demanda que se pretende atender;

IV - agregar aos terminais de transporte coletivo urbano infra-estrutura apropriada para a guarda de bicicletas;

V - estabelecer negociações com o Estado de São Paulo com o objetivo de permitir o acesso e transporte, em vagão especial no metrô e em trens metropolitanos, de ciclistas com suas bicicletas;

VI - promover atividades educativas visando à formação de comportamento seguro e responsável no uso da bicicleta e sobretudo no uso do espaço compartilhado;

VII - promover o lazer ciclístico e a conscientização ecológica.

Art. $4^{\circ}$ Caberá ao Executivo, por meio dos órgãos competentes, consolidar o programa de implantação do Sistema Cicloviário do Município de São Paulo, considerando as propostas contidas nos Planos Regionais Estratégicos.

Art. $5^{\circ} \mathrm{A}$ ciclovia será constituída de pista própria para a circulação de bicicletas, separada fisicamente do tráfego geral e atendendo o seguinte:

I - ser totalmente segregada da pista de rolamento do tráfego geral, calçada, acostamento, ilha ou canteiro central;

II - poderão ser implantadas na lateral da faixa de domínio das vias públicas, no canteiro central, em terrenos marginais às linhas férreas, nas margens de cursos d'água, nos parques e em outros locais de interesse;

III - ter traçado e dimensões adequados para segurança do tráfego de bicicletas e possuindo sinalização de trânsito específica.

Art. $6^{\circ} \mathrm{A}$ ciclofaixa consistirá numa faixa exclusiva destinada à circulação de bicicletas, delimitada por sinalização específica, utilizando parte da pista ou da calçada.

Parágrafo único. A ciclofaixa poderá ser adotada quando não houver disponibilidade de espaço físico ou de recursos financeiros para a construção de uma ciclovia, desde que as 
condições físico-operacionais do tráfego motorizado sejam compatíveis com a circulação de bicicletas.

Art. $7^{\circ} \mathrm{A}$ faixa compartilhada poderá utilizar parte da via pública, desde que devidamente sinalizada, permitindo a circulação compartilhada de bicicletas com o trânsito de veículos motorizados ou pedestres, conforme previsto no Código de Trânsito Brasileiro.

$\S 1^{\circ} \mathrm{A}$ faixa compartilhada deve ser utilizada somente em casos especiais para dar continuidade ao sistema cicloviário ou em parques, quando não for possível a construção de ciclovia ou ciclofaixa.

$\S 2^{\circ}$ A faixa compartilhada poderá ser instalada na calçada, desde que autorizado e devidamente sinalizado pelo Órgão Executivo Municipal de Trânsito nos casos em que não comprometer a mobilidade segura e confortável do pedestre.

Art. $8^{\circ}$ Os terminais e estações de transferência do SITP, os edifícios públicos, as indústrias, escolas, centros de compras, condomínios, parques e outros locais de grande afluxo de pessoas deverão possuir locais para estacionamento de bicicletas, bicicletários e paraciclos como parte da infra-estrutura de apoio a esse modal de transporte.

$\S 1^{\circ} \mathrm{O}$ bicicletário é o local destinado para estacionamento de longa duração de bicicletas e poderá ser público ou privado.

$\S 2^{\circ} \mathrm{O}$ paraciclo é o local destinado ao estacionamento de bicicletas de curta e média duração em espaço público, equipado com dispositivos para acomodá-las.

Art. $9^{\circ} \mathrm{A}$ elaboração de projetos e construção de praças e parques, incluindo os parques lineares, com área superior a $4.000 \mathrm{~m}^{2}$ (quatro mil metros quadrados), deve contemplar o tratamento cicloviário nos acessos e no entorno próximo, assim como paraciclos no seu interior.

Art. 10. O Executivo deverá estimular a implantação de locais reservados para bicicletários, em um raio de 100 (cem) metros dos terminais e estações de metrô, trens metropolitanos e corredores de ônibus metropolitanos, dando prioridade às estações localizadas nos cruzamentos com vias estruturais.

Parágrafo único. A segurança do ciclista e do pedestre é condicionante na escolha do local e mesmo para a implantação de bicicletários.

Art. 11. As novas vias públicas, incluindo pontes, viadutos e túneis, devem prever espaços destinados ao acesso e circulação de bicicletas, em conformidade com os estudos de viabilidade.

Art. 12. O Executivo poderá implantar ou incentivar a implantação de ciclovias ou ciclofaixas nos terrenos marginais às linhas férreas em trechos urbanos, de interesse turístico, nos acessos às zonas industriais, comerciais e institucionais, quando houver demanda existente e viabilidade técnica.

Parágrafo único. Os projetos dos parques lineares previstos no Plano Diretor Estratégico e nos Planos Regionais Estratégicos deverão contemplar ciclovias internas e, quando possível, de acesso aos parques, em conformidade com estudos de viabilidade aprovados. 
Art. 13. A implantação e operação dos bicicletários, em imóveis públicos ou privados, deverá ter controle de acesso, a ser aprovado pelo Órgão Executivo Municipal de Trânsito.

Art. 14. Nas ciclovias, ciclofaixas e locais de trânsito compartilhado poderá ser permitido, de acordo com regulamentação pelo Órgão Executivo Municipal de Trânsito, além da circulação de bicicletas:

I - circular com veículos em atendimento a situações de emergência, conforme previsto no Código de Trânsito Brasileiro e respeitando-se a segurança dos usuários do sistema cicloviário;

II - utilizar patins, patinetes e skates, nas pistas onde sua presença não seja expressamente proibida;

III - circular com o uso de bicicletas, patinetes ou similares elétricos, desde que desempenhem velocidades compatíveis com a segurança do ciclista ou do pedestre onde exista trânsito partilhado.

Art. 15. O Executivo deve manter ações educativas permanentes com o objetivo de promover padrões de comportamento seguros e responsáveis dos ciclistas, assim como deverá promover campanhas educativas, tendo como público-alvo os pedestres e os condutores de veículos, motorizados ou não, visando divulgar o uso adequado de espaços compartilhados.

Art. 16. Os eventos ciclísticos, utilizando via pública, somente podem ser realizados em rotas, dias e horários autorizados pelo Órgão Executivo Municipal de Trânsito, a partir de solicitação expressa formulada pelos organizadores do evento.

Art. 17. As despesas decorrentes da execução desta lei correrão por conta de dotações orçamentárias próprias, suplementadas se necessário.

Art. 18. Esta lei entrará em vigor na data de sua publicação, revogadas as disposições em contrário.

PREFEITURA DO MUNICÍPIO DE SÃO PAULO, aos 6 de fevereiro de 2007, 454 da fundação de São Paulo.

GILBERTO KASSAB, PREFEITO

Publicada na Secretaria do Governo Municipal, em 6 de fevereiro de 2007.

CLOVIS DE BARROS CARVALHO, Secretário do Governo Municipal 


\subsection{DECRETO № 50.708, DE 2 DE JULHO DE 2009 - Passa a coordenação do Grupo Pró Ciclista para a SMT}

Atribui à Secretaria Municipal de Transportes a gestão e a coordenação do Grupo Executivo da Prefeitura do Município de São Paulo para Melhoramentos Cicloviários - Pró-Ciclista.

GILBERTO KASSAB, Prefeito do Município de São Paulo, no uso das atribuições que the são conferidas por lei,

CONSIDERANDO que, nos termos da Lei $\mathrm{n}^{\circ} 14.266$, de 6 de fevereiro de 2007, o transporte por bicicletas deve ser abordado como meio de transporte para as atividades do cotidiano e, nesse sentido, considerado modal efetivo na mobilidade da população,

DE CRETA:

Art. $1^{\circ}$. Fica atribuída à Secretaria Municipal de Transportes a gestão e a coordenação do Grupo Executivo da Prefeitura do Município de São Paulo para Melhoramentos Cicloviários - Pró-Ciclista, criado pela Portaria n 1.918 - PREF, de 18 de maio de 2006.

Parágrafo único. O Secretário Municipal de Transportes será o coordenador do PróCiclista, a quem incumbirá adotar medidas destinadas ao pleno funcionamento do colegiado.

Art. $2^{\circ}$. Este decreto entrará em vigor da data de sua publicação.

PREFEITURA DO MUNICÍPIO DE SÃO PAULO, aos 2 de julho de $2009,456^{\circ}$ da fundação de São Paulo.

GILBERTO KASSAB, PREFEITO

MÁGINO ALVES BARBOSA FILHO, Secretário Municipal de Transportes - Substituto

Publicado na Secretaria do Governo Municipal, em 2 de julho de 2009.

CLOVIS DE BARROS CARVALHO, Secretário do Governo Municipal

\subsection{DECRETO N 51.622, DE 12 DE JULHO DE 2010 - Cria a Rota Turística Márcia Prado ${ }^{91}$}

Regulamenta a Lei $n^{\circ}$ 15.094, de 4 de janeiro de 2010, que institui a Rota de CicloTurismo Márcia Prado, na região entre o Grajaú e a Ilha do Bororé, passando pela Área de Proteção Ambiental Municipal - APA Bororé-Colônia, no Município de São Paulo.

ALDA MARCO ANTONIO, Vice-Prefeita, em exercício no cargo de Prefeito do Município de São Paulo, no uso das atribuições que lhe são conferidas por lei,

D E C R E T A:

Art. $1^{\circ}$. A Rota de Ciclo-Turismo Márcia Prado, instituída pela Lei $\mathrm{n}^{\circ} 15.094$, de 4 de janeiro de 2010, consistente em roteiro turístico cicloviário entre o Bairro do Grajaú e a Ilha do Bororé, passando pela região da Área de Proteção Ambiental Municipal - APA Bororé-Colônia, estender-se-á por toda a Avenida Dona Belmira Marin, desde a Avenida Tancredo Neves até a Balsa do Bororé.

Art. $2^{\circ}$. A Rota de Ciclo-Turismo Márcia Prado está vinculada ao Plano de Ciclovias da Secretaria Municipal de Transportes e sua implantação obedecerá ao cronograma e aos recursos nele previstos.

\footnotetext{
${ }^{91}$ Rota situada ao longo da Av. Belmira Marin, iniciando na Estação/Terminal Grajaú até a Balsa do Bororé onde se prolonga por área externa ao município de SP. O nome Márcia Prado é em homenagem a cicloativista morta na Av. Paulista - primeira Ghost Bike implantada na cidade.
} 
Art. $3^{\circ}$. O trajeto será dotado de infraestrutura cicloviária protegida e segregada em relação ao tráfego motorizado, no sentido de ser garantida total segurança e conforto aos seus usuários.

Art. $4^{\circ}$. Este decreto entrará em vigor na data de sua publicação.

PREFEITURA DO MUNICÍPIO DE SÃO PAULO, aos 12 de julho de $2010,457^{\circ}$ da fundação de São Paulo.

ALDA MARCO ANTONIO, Prefeita em Exercício

MARCELO CARDINALE BRANCO, Secretário Municipal de Transportes

EDUARDO JORGE MARTINS ALVES SOBRINHO, Secretário Municipal do Verde e do Meio

Ambiente Publicado na Secretaria do Governo Municipal, em 12 de julho de 2010.

CLOVIS DE BARROS CARVALHO, Secretário do Governo Municipal

\subsection{DECRETO № 51.665, DE 26 DE JULHO DE 2010 - Obrigatoriedade de seguro contra roubo de moto e bicicleta em estacionamentos.}

Regulamenta a Lei $n^{\circ} 15.200$, de 18 de junho de 2010, que altera as disposições sobre a obrigatoriedade de cobertura de seguro contra furto ou roubo nos estabelecimentos de uso nR2 e nR3 que possuam estacionamento com número de vagas superiora 50 (cinquenta).

GILBERTO KASSAB, Prefeito do Município de São Paulo, no usodas atribuições que the são conferidas por lei, DECRETA:

Art. $1^{\circ}$. Os estabelecimentos enquadrados nos usos não residenciais2 e 3 (nR2 e nR3), conforme previsto na Lei $\mathrm{n}^{\circ} 13.885$, de 25 de agosto de 2004 , que possuam estacionamento comcapacidade superior a 50 (cinquenta) vagas, ficam obrigados a efetuar cobertura de seguro contra furto e roubo dos veículosautomotores, inclusive motocicletas, e das bicicletas nelesestacionados, de acordo com as disposições constantes da Lein ${ }^{\circ} 15.200$, de 18 de junho de 2010 , ora regulamentada por este decreto.

Parágrafo único. Cuidando-se de estacionamento terceirizado ou sob concessão, será responsável pelo cumprimento da obrigação prevista no "caput" o terceiro ou o concessionário.

Art. $2^{\circ}$. Os proprietários dos veículos automotores, inclusivemotocicletas, ou bicicletas que tenham sido comprovadamente sinistrados nos estacionamentos referidos no artigo $1^{\circ}$ deste decreto deverão ser indenizados, obrigatoriamente, pelo valorde mercado do bem na data do pagamento.

Art. $3^{\circ}$. Os estabelecimentos aos quais se refere este decreto deverão se equipar, para salvaguarda de direitos e ressarcimento de eventuais sinistros, de instrumentos e procedimentos de controle que forneçam aos condutores comprovação do estacionamento do veículo, inclusive motocicleta, ou bicicleta.

Parágrafo único. O comprovante de estacionamento deverá estar de acordo com as normas da empresa seguradora, tornando- se prova hábil em juízo.

Art. $4^{\circ}$. Caso seja necessária a implantação de equipamentos e sistemas de controle para atendimento das disposições da Lei $n^{\circ} 15.200$, de 18 de junho de 2010, bem como deste decreto, o seu funcionamento não poderá prejudicar o trânsito na via pública.

Parágrafo único. Nos estacionamentos de estabelecimentos enquadrados no Decreto $\mathrm{n}^{\circ}$ 32.329 , de 23 de setembro de 1992, e na Lei $n^{\circ} 15.150$, de 6 de maio de 2010, a implantação referida neste artigo deverá ser previamente submetida à aprovação da Secretaria Municipal de Transportes. 
Art. $5^{\circ}$. Para efeito de fiscalização, os responsáveis pelos estacionamentos deverão manter em seu poder documento que comprove a cobertura do seguro de que trata a Lei $\mathrm{n}^{\circ} 15.200$, de 2010 , com prazo de validade em vigor.

Art. $6^{\circ}$. O descumprimento de quaisquer das disposições previstas na Lei $n^{\circ} 15.200$, de 2010 , e neste decreto, sujeitará o infrator ao pagamento de multa diária no valor de $\mathrm{R} \$$ $1.000,00$ (mil reais), até a sua regularização.

$\S 1^{\circ}$. Sem prejuízo da imposição da multa, o infrator será intimado a sanar as irregularidades e a comunicar, obrigatória e imediatamente, à Subprefeitura competente a regularização procedida.

$\S 2^{\circ}$. O valor da multa será corrigido anualmente pelo Índice de Preços ao Consumidor, da Fundação Instituto de Pesquisas Econômicas - FIPE, ou, na hipótese de sua extinção, por outro que reflita a inflação do período.

Art. $7^{\circ}$. Compete às Subprefeituras fiscalizar o cumprimento dasdisposiçõos previstas na Lei $n^{\circ} 15.200$, de 2010 , e neste decreto,bem como aplicar as penalidades administrativas pertinentes.

Art. $8^{\circ}$. Os estabelecimentos terão o prazo de 30 (trinta) dias, contados da data de publicação deste decreto, para se adaptaremàs normas constantes do presente regulamento.

Parágrafo único. O prazo estabelecido no "caput" deste artigo poderá ser prorrogado por, no máximo, 30 (trinta) dias, a critério do responsável pela Coordenadoria de Planejamento e Desenvolvimento Urbano - CPDU, mediante pedido justificado do interessado, protocolado na Subprefeitura em cujo território se situa o estabelecimento.

Art. $9^{\circ}$. Este decreto entrará em vigor na data de sua publicação. PREFEITURA DO MUNICÍPIO DE SÃO PAULO, aos 26 de julho de 2010, $457^{\circ}$ da fundação de São Paulo.

GILBERTO KASSAB, PREFEITO

RONALDO SOUZA CAMARGO, Secretário Municipal de Coordenação das Subprefeituras

Publicado na Secretaria do Governo Municipal, em 26 de julho de 2010.

CLOVIS DE BARROS CARVALHO, Secretário do Governo Municipal

\subsection{LEI No 15.649, DE 5 DE DEZEMBRO DE 2012 - Obrigatoriedade de previsão de vagas para estacionamento de bicicletas em edificações sob a legislação de Polos Geradores}

(Projeto de Lei $n^{\circ} 527 / 09$, do Vereador Marco Aurélio Cunha - PSD)

Altera o item 13.3.4 do Anexo I da Lei $n^{\circ} 11.228$, de 25 de julho de 1992, o conceito e os parâmetros de Jirau constantes na Seção 1.1 e na Tabela 10.11, ambos da Lei $n^{\circ} 11.228$, de 25 de julho de 1992, e dá outras providências.

GILBERTO KASSAB, Prefeito do Município de São Paulo, no uso das atribuições que the são conferidas por lei, faz saber que a Câmara Municipal, em sessão de 31 de outubro de 2012, decretou e eu promulgo a seguinte lei:

Art. $1^{\circ} \mathrm{O}$ item 13.3.4 do Anexo I da Lei $\mathrm{n}^{\circ} 11.228$, de 25 de junho de 1992, passa a exibir a seguinte redação:

“13.3.4 Deverão ser previstas vagas para veículos de pessoas com deficiência e/ou mobilidade reduzida, motocicletas e bicicletas, calculadas sobre o mínimo de vagas exigido pela LPUOS, observando a proporcionalidade fixada na tabela 13.3.4. 
Tabela 13.3.4 - Porcentagem de vagas destinadas a pessoas com deficiência e/ou mobilidade reduzida, motocicletas e bicicletas

Estacionamento Deficiente Motocicleta Bicicleta

Privativo até 100 vagas - $10 \% 5 \%$

Privativo mais de 100 vagas $1 \% 10 \% 5 \%$

Coletivo até 10 vagas - 20\% 10\%

Coletivo mais de 10 vagas $3 \% 20 \% 10 \%$

(NR)"

Art. $2^{\circ} \mathrm{O}$ conceito de Jirau constante da Seção 1.1 - Conceitos da Lei $n^{\circ} 11.228$, de 1992, passa a vigorar com a seguinte redação:

“....

Jirau: mobiliário constituído por estrado ou passadiço instalado a meia altura em compartimento, sem permanência humana prolongada.

Art. $3^{\circ}$ Os parâmetros estabelecidos para o Jirau na Tabela 10.11 - Mobiliário, da Seção 10.11 da Lei $n^{\circ} 11.228$, de 1992, passam a ser os seguintes:

Tabela 10.11 - Mobiliário

Mobiliário Dimensões máximas

Jirau Área: $250,00 \mathrm{~m}^{2}$

Ocupação: $30 \%$ da área do compartimento, incluindo a circulação vertical de acesso

Pé direito: $2,30 \mathrm{~m}$

Art. $4^{\circ}$ As despesas decorrentes da execução desta lei correrão por conta das dotações orçamentárias próprias, suplementadas se necessário.

Art. $5^{\circ} 0$ Executivo regulamentará esta lei no prazo de 60 (sessenta) dias, contados da data de sua publicação.

Art. $6^{\circ}$ Esta lei entrará em vigor na data de sua publicação.

PREFEITURA DO MUNICÍPIO DE SÃO PAULO, aos 5 de dezembro de $2012,459^{\circ}$ da

fundação de São Paulo.

GILBERTO KASSAB, PREFEITO

NELSON HERVEY COSTA, Secretário do Governo Municipal

Publicada na Secretaria do Governo Municipal, em 5 de dezembro de 2012.

\subsection{DECRETO No 53.942, DE 28 DE MAIO DE 2013 - Decreto que regulamenta a lei anterior}

Regulamenta a Lei $n^{\circ} 15.649$, de 5 de dezembro de 2012, que introduz alterações

na Lei $\mathrm{n}^{\circ} 11.228$, de 25 de julho de 1992 , no que tange à previsão de vagas destinadas a bicicletas em estacionamentos, bem como no conceito e parâmetros de

"Jirau".

FERNANDO HADDAD, Prefeito do Município de São Paulo,

no uso das atribuições que the são conferidas por lei,

D E C R E T A:

Art. $1^{\circ}$ Nos espaços de estacionamento, as vagas destinadas a bicicletas, calculadas de acordo com o item 13.3.4 do Capítulo 13 do Anexo I da Lei 11.228, de 25 de julho de 1992, com as alterações introduzidas pela Lei $n^{\circ}$ 15.649, de 5 de dezembro de 2012, deverão atender às seguintes condições:

I - localização em bolsões isolados das vagas de veículos automotores, como automóveis e motocicletas;

II - facilidade de acesso, com localização no piso mais próximo do logradouro público e acesso garantido aos usuários do estacionamento;

III - instalação de suportes para prender as bicicletas, com distância mínima de $0,75 \mathrm{~m}$ (setenta e cinco centímetros) entre eles; 
IV - comprimento mínimo de $1,80 \mathrm{~m}$ (um metro e oitenta centímetros), em espaço com pé direito mínimo de $2,00 \mathrm{~m}$ (dois metros).

Parágrafo único. Poderão ser aceitas configurações e dimensões diversas das estabelecidas no "caput" deste artigo de acordo com a solução adotada no projeto.

Art. $2^{\circ} \mathrm{O}$ disposto no artigo $1^{\circ}$ deste decreto aplica-se aos pedidos de Alvará de Aprovação e Execução de edificação nova, de reforma ou de aprovação de projeto modificativo protocolados a partir da publicação deste decreto.

Parágrafo único. Nos pedidos de reforma e de projeto modificativo o número de vagas destinadas a bicicletas será calculado em relação ao acréscimo de área computável solicitado.

Art. $3^{\circ}$ Ficam isentas do atendimento das disposições deste decreto as edificações:

I - localizadas no alinhamento de vias públicas e que não possuam área com acesso para estacionamento;

II - localizadas em vias nas quais o tráfego de bicicletas é proibido pelo órgão municipal de trânsito;

III - que não possuam área de estacionamento.

Art. $4^{\circ} \mathrm{O}$ conceito de Jirau constante do inciso VIII do

Anexo 1 e o item 13.C.2 da Seção 13.C do Anexo 13, ambos do Decreto $n^{\circ} 32.329$, de 23 de setembro de 1992, passam a vigorar com a seguinte redação:

"Anexo 1

Conceitos

VIII - Jirau: é o mobiliário constituído por estrado ou passadiço instalado a meia altura em compartimento, sem permanência humana prolongada, observados os

parâmetros estabelecidos na Tabela 10.11 - Mobiliário, da Seção 10.11 do COE, com as alterações promovidas pelo artigo $3^{\circ}$ da Lei $n^{\circ} 15.649$, de 5 de dezembro de

2012. " (NR)

“Anexo 13

Estacionamento

SEÇÃO 13.C - Espaços para Manobra e Estacionamento

13.C.2 - A porcentagem de vagas destinadas a pessoas com deficiência e/ou mobilidade reduzida, motocicletas e bicicletas, conforme Tabela 13.3.4 do COE, com as alterações promovidas pelo artigo $1^{\circ}$ da Lei $n^{\circ} 15.649$, de 5 de dezembro de 2012, será acrescida, em número de vagas, ao mínimo exigido pela LPUOS, devendo ser demarcadas.

Art. $5^{\circ}$ Este decreto entrará em vigor na data de sua publicação, revogada a nota (1) do Desenho 1.II - Conceitos do Anexo 18 do Decreto $n^{\circ} 32.329$, de 1992.

PREFEITURA DO MUNICÍPIO DE SÃO PAULO, aos $28 \mathrm{de}$ maio de $2013,460^{\circ}$ da fundação de São Paulo.

FERNANDO HADDAD, PREFEITO

PAULA MARIA MOTTA LARA, Secretária Especial de Licenciamentos

ANTONIO DONATO MADORMO, Secretário do Governo

Municipal

Publicado na Secretaria do Governo Municipal, em 28 de

maio de 2013. 
3.18. Outras leis e decretos municipais:

LEI N : 11537

Assinatura

23/05/94

24/05/94 Publicação

Retificação

02/06/94, Folha 1

Ementa:

INSTITUI A CICLOVIA DO TATUAPE, E DA OUTRAS PROVIDENCIAS.(PL 747/93)

DESPACHO N: 90309 Ano: 1994 Secretaria: SVMA

Publicação

03/09/94, Folha 2

Retificação

06/09/94, Folha 1

Ementa:

DETERMINA PARALISACAO DAS OBRAS DE CICLOVIA NO PARQUE IBIRAPUERA; RETOMADA SO APOS APROVACAO DO PROJETO PELO CONDEPHAAT;PROIBICAO NAO AFETA MANUTENCAOSEGURANCA PISTA DE COOPER.

LEI N $N^{\circ}: 11730$

$$
\begin{array}{cr}
\text { Assinatura } & \begin{array}{c}
\text { Publicação } \\
\text { 09/03/95 }
\end{array} \\
10 / 03 / 95, \text { Folha } 1
\end{array}
$$

Ementa:

INSTITUI A CICLOVIA DO BELENZINHO, E DA OUTRAS PROVIDENCIAS.

LEI $N^{\circ}: 12400$

$$
\begin{array}{cc}
\text { Assinatura } & \text { Publicação } \\
\text { 03/07/97 } & \text { 04/07/97, Folha } 1
\end{array}
$$

Ementa:

INSTITUI A CICLOVIA DA MOOCA, E DA OUTRAS PROVIDENCIAS. (PL 299/94)

PORTARIA No: 70 Ano: 1997 Secretaria: SVMA

Publicação

18/10/97, Folha 18

Ementa:

CONSTITUI GT P/ PESQUISA E AVALIACAO DOS ACIDENTES NAS CICLOVIAS DOS PARQUES MUNICIPAIS.

PORTARIA N: 81 Ano: 1997 Secretaria: SVMA

Publicação

24/12/97, Folha 18

Ementa:

CONSTITUI COMISSAO PARA PROCEDEREM A ANALISE E APROVACAO DOS RELATORIOS MENSAIS DE MEDICAO DOS SERVICOS EXECUTADOS, DA SINALIZACAO RELATIVO A CICLOVIANO PARQUE DO CARMO. 
LEI $\mathrm{N}^{\circ}: 12814$

Assinatura

31/03/99
Publicação

01/04/99, Folha 1

Ementa:

INSTITUI A CICLOVIA DO IPIRANGA, E DA OUTRAS PROVIDENCIAS. (PL 774/98) 


\section{ANEXO II - CICLOATIVISMO}


Explicações para a consulta do Anexo II - Cicloativismo

Este anexo contém material divulgado pela internet por ONGs e Blogs de cicloativismo.Seu intuito é documentar o pensamento e atitude dos vários órgãos que representam o movimento cicloativista do município de São Paulo.

A escolha dos mesmos não foi submetida a qualquer critério pré-estabelecido, trata-se de exemplos que fundamentam o que foi exposto e comentado na presente tese. Foram extraídos de consultas aos sites foram realizadas via internet em 13/12/2013 no período da tarde.

A seguir são listados as ONGs e blogs de cicloativismo com explicação sucinta da linha de trabalho e interesses com texto retirados de suas próprias páginas:

\section{Site Vádebike - Willian Cruz:}

“O Vá de Bike foi criado com o objetivo principal de ajudar quem está começando a usar a bicicleta como meio de transporte e a incentivar quem tem essa vontade, mas ainda não conseguiu colocá-la em prática. Suas Dicas para o Ciclista Urbano tornaram-se referência em recomendações para iniciantes e serviram de inspiração para muitos outros sites, manuais e matérias na imprensa.

O projeto já tem uma década de história no apoio ao ciclista urbano, através de conteúdo no site, palestras, cursos, passeios e atividades, visando principalmente o apoio a quem usa a bicicleta nas cidades e a segurança do ciclista nas ruas.

Nesse tempo, foram publicadas no site mais de mil páginas de conteúdo relevante para quem usa a bicicleta nas grandes cidades, com predominância de conteúdo próprio e de opinião." 


\section{Blog Bicicreteiro - André Pasqualini}

"Bicicreteiro pode ser várias pessoas. Algumas pessoas costumam chamar alguém de bicicreteiro, de forma pejorativa, se referindo a um ciclista que pedala de forma inconseqüente, colocando em risco os pedestres e sua vida. Há também aqueles que se referem aos ciclistas mais humildes como bicicreteiro, como forma de diminuí-lo, criando a categoria "Ciclista" (entidade superior) e o "Bicicreteiro" como "o mais baixo na escala social do ciclismo" (inspirado pelo ilustre Casoy).

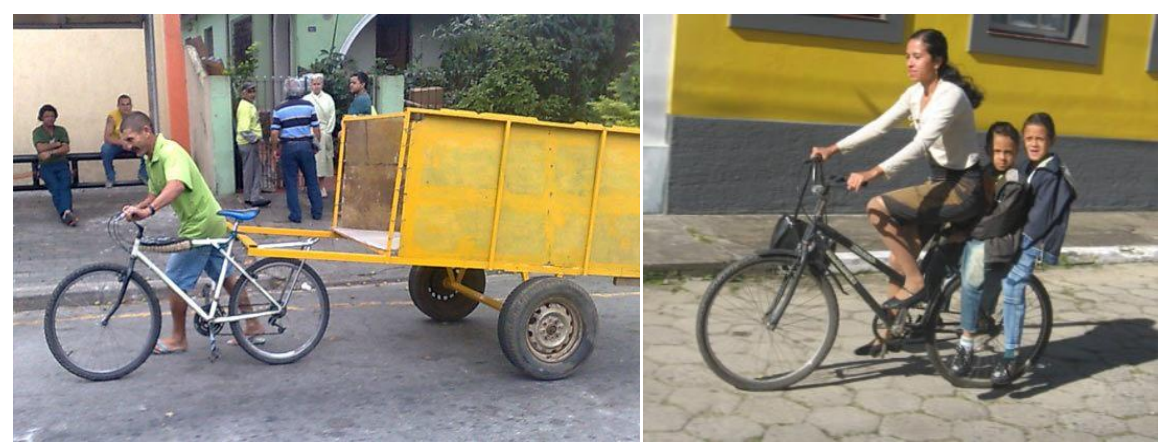

Mas há outras pessoas que se referem a um Bicicreteiro, como um ciclista acima da média, alguém especialista no assunto, que pedala muito, praticamente um atleta. Ser chamado de Bicicreteiro por essas pessoas, vem a ser o máximo de elogio que um ciclista pode receber

O objetivo desse blog é representar todos Bicicreteiros citados acima. Esse cara pode tanto pedalar de barra forte, com chapéu de palha e chinelo, como andar com uma estradeira de 5 mil reais, levando um pelotão no peito.

Quero com o blog mostrar a infinidade de variações que temos no mundo do ciclismo, além de quebrar alguns mitos que impedem que tenhamos um número maior de pessoas pedalando. Quero mostrar que ninguém é melhor ou pior, que seja lá como a pessoa pedale, todos são ciclistas e qualquer pessoa pode ser ciclista. Que pedalar pode ser muito mais simples e prazeroso do que parece, que o mundo da bicicleta é maravilhoso, intenso e vibrante. Não importa as diferenças, no fundo todos querem ver mais ciclistas nas ruas, o mundo da bicicleta só parece complicado, mas ele é acessível e qualquer um pode participar." 


\section{Blog Bikeanjo}

"Bike Anjos são ciclistas experientes e apaixonados pelo seu meio de
transporte que ajudam pessoas que querem aprender a andar de bicicleta
na cidade com mais segurança.
Podemos dar assistência em melhores trajetos para se fazer, acompanhar
o ciclista iniciante em suas primeiras pedaladas, e ensinar manutenção
básica e medidas de segurança no trânsito.
E o melhor: o "serviço" é oferecido gratuitamente. Isso mesmo, de graça!
Mas por que? Porque acreditamos em uma cidade melhor, com um trânsito
mais seguro para as pessoas, por meio da educação e orientação, e mais
do que isso, porque nós também já fomos iniciantes e sabemos como é
começar a pedalar na cidade."

\section{ONG Ciclocidade - Associação dos Ciclistas Urbanos de São Paulo - Thiago Benícchio}

"A Ciclocidade é uma associação sem fins lucrativos, que tem como missão contribuir para a construção de uma cidade mais sustentável, baseada na igualdade de acesso a direitos, promovendo a mobilidade e o uso da bicicleta como instrumento de transformação.

No formato de uma Associação dos Ciclistas Urbanos de São Paulo, a Ciclocidade foi fundada em novembro de 2009, a partir da reunião de dezenas de cidadãos atuantes na defesa da mobilidade por bicicletas, que perceberam a necessidade de uma entidade representativa para ampliar o alcance de suas ações individuais.

Trabalhamos pela construção de políticas públicas e iniciativas que atendam a mobilidade por bicicletas. Realizamos atividades e projetos que buscam fortalecer e propagar a cultura da bicicleta em todas as esferas da sociedade. 
Queremos que todos que circulam nas ruas tenham o direito à vida, segurança e conforto em seus deslocamentos. Defendemos atenção e benefícios crescentes para os ciclistas e para todos os cidadãos que utilizam alternativas inteligentes de locomoção.

A bicicleta pode ser uma alternativa de locomoção para muitas pessoas ou para muitas situações do cotidiano, amplificando as possibilidades de mobilidade urbana e melhorando a qualidade de vida dos cidadãos."

\section{Blog Escola de Bicicleta - Arthuro Alcorta}

"Este é um site institucional, dirigido a todos os interessados pela bicicleta e seu universo, independentemente da razão ou do uso a que ela se destina.

Disponibilizamos informações básicas para melhorar o uso da bicicleta procurando dar uma formação que leve o leitor à responsabilidade pessoal e social. Os textos foram escritos com base em décadas de pesquisa e experiência, acumuladas no dia a dia, por nossa equipe.

Não nos responsabilizamos por possíveis erros de compreensão dos textos apresentados. Estamos disponíveis para esclarecer dúvidas.

Para solicitar informações sobre o conteúdo disponibilizado neste website, por favor, entre em contato conosco através do nosso formulário contato."

\section{Redes Sociais}

Finalizamos a descrição do pensamento cicloativista com a reprodução de um diálogo retirado de uma das páginas de redes sociais mais utilizadas atualmente, o Facebook.

No diálogo fica exposta a opinião de cicloativistas sobre o atendimento às regras de trânsito para utilização do sistema viário pelo condutor da bicicleta.

O nome dos cicloativistas foram omitidos porque o mais importante é o registro de suas opiniões. 


\section{SITE VADEBIKE:}

\section{Patrocínio Banco Itaú \\ Itaú}

O que o Código de Trânsito diz sobre bicicletas e ciclistas B WILLIAN CRUZ

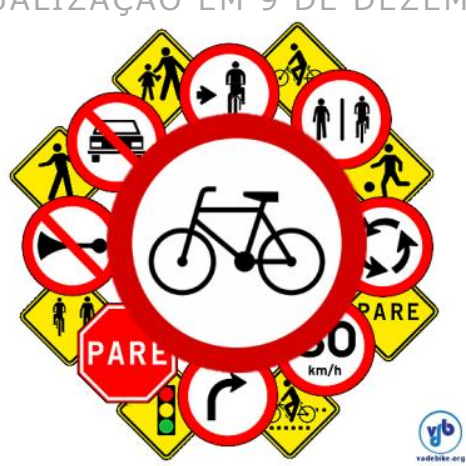

Ao contrário do que muita gente acredita, o texto do Código Brasileiro de Trânsito valoriza essencialmente a vida, não o fluxo de veículos. Na redação de seus artigos, percebe-se uma preocupação acima de tudo com a integridade física dos diversos atores do tráfego, sejam eles motoristas, motociclistas, ciclistas ou pedestres.

Bicicletas, triciclos, handbikes e outras variações são todos considerados veículos, com direito de circulação pelas ruas e prioridade sobre os automotores. Portanto, quando falarmos embicicletas neste artigo, considere que podem também ser "ciclos" de outra natureza.

Veja abaixo todos os artigos que se referem a esses meios de transporte:

Bicicletas, triciclos, handbikes e outros também são veículos:

BICICLETA - veículo de propulsão humana, dotado de duas rodas, não sendo, para efeito deste Código, similar à motocicleta, motoneta e ciclomotor.

CICLO - veículo de pelo menos duas rodas a propulsão humana.

Órgãos de trânsito têm obrigação de garantir a Saiba mais

Handbike, uma bicicleta inclusiva

Uma boa solução para regulamentar as bicicletas elétricas segurança de ciclistas:

Art. 21. Compete aos órgãos e entidades executivosrodoviários da União, dos Estados, do Distrito Federal e dos Municípios, no âmbito de sua circunscrição:

(...) 
II - planejar, projetar, regulamentar e operar o trânsito de veículos de pedestres e de animais, epromover o desenvolvimento da circulação e segurança de ciclistas.

(o Art. 24 dispõe o mesmo sobre os órgãos e entidades executivos de trânsito dos Municípios)

Pedestres têm prioridade sobre ciclistas; ciclistas têm prioridade sobre outros veículos:

Art. 29. O trânsito de veículos nas vias terrestres abertas à circulação obedecerá às seguintes normas:

(...)

$\S 2^{\circ}$ Respeitadas as normas de circulação e conduta estabelecidas neste artigo, em ordem decrescente, os veículos de maior porte serão sempre responsáveis pela segurança dos menores, os motorizados pelos não motorizados e, juntos, pela incolumidade dos pedestres.

Motoristas não devem "fechar" bicicletas:

\section{Saiba mais}

Fiscalização e multas a

motoristas - mas e os ciclistas?

Art. 38. Antes de entrar à direita ou à esquerda, em outra via ou em lotes lindeiros, o condutor deverá:

(...)

Parágrafo único. Durante a manobra de mudança de direção, o condutor deverá ceder passagem aos pedestres e ciclistas, aos veículos que transitem em sentido contrário pela pista da via da qual vai sair, respeitadas as normas de preferência de passagem.

Ameaçar o ciclista com o carro é infração gravíssima, passível de

\section{Saiba mais}

É justa a multa a motoristas que passam perto de ciclistas? suspensão do direito de dirigir e apreensão do veículo e da habilitação:

Art. 170. Dirigir ameaçando os pedestres que estejam atravessando a via pública, ou os demais veículos:

Infração - gravíssima;

Penalidade - multa e suspensão do direito de dirigir;

Medida administrativa - retenção do veículo e recolhimento do documento de habilitação.

Colar na traseira do ciclista ou apertá-lo contra a calçada é infração grave:

\section{Preconceito contra ciclistas}

B WILLIAN CRUZ | ÚLTIMA ATUALIZAÇÃO EM 17 DE OUTUBRO DE 2012 


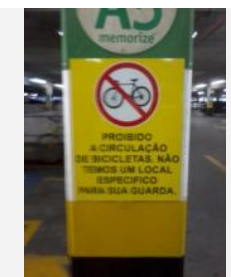

O unidade Jaguaré do Extra, em São Paulo, não queria atender essa gente que anda de bicicleta. Segundo o leitor Adriano, a situação foi resolvida após troca da empresa que administrava o estacionamento. Foto: Fabio Fau

Pouco se fala no assunto, mas pessoas em bicicletas sofrem um forte preconceito no Brasil, sobretudo nas grandes cidades do país.

Para dar um primeiro exemplo, algum tempo atrás o Vá de Bike denunciou a maneira como eram recebidos os ciclistasem um shopping center de São Paulo, dando oportunidade para a empresa se defender e mudar seu atendimento. Um mês depois, a Aline Cavalcante voltou ao local para averiguar, mas a situação não havia melhorado muito.

Para ser justo, estive lá seis meses depois da publicação do primeiro texto, sem que houvesse nenhum problema e nem mesmo cara feia dos seguranças. Talvez a recepção neutra tenha sido porque entrei pedalando bem vestido e com roupas formais (camisa e calça social), mas espero sinceramente que "preconceito às avessas" não seja o motivo para me receberem em bicicleta do mesmo modo que recebem os demais clientes em carros - e isso é tudo que pedimos.

\section{$\gg$ No Conjunto Nacional (Av.Paulista), ciclista é chamado de "palhaço" $<<$}

\section{Apartheid veicular}

Não à toa, quando escrevi sobre o shopping estabeleci uma comparação indireta com a segregação racial que ocorria algumas décadas atrás, nos Estados Unidos e em outros países, através de uma das imagens que ilustrava o texto (a placa "whites only beyond this point", presente também nesta página).

Como cidadãos de segunda classe, ciclistas são impedidos de adentrar garagens de estabelecimentos, de trafegar em rodovias e pontes, de utilizar drive thrus de lanchonetes, de guardar a bicicleta em estacionamentos e, indiretamente, até de entrar em estabelecimentos comerciais (ao serem impedidos, intencionalmente ou não, de estacionar onde automóveis são permitidos).

Há um ótimo artigo no site Bike Is Beautiful, do porto-alegrense Enrico Canali, que me fez refletir sobre outro ponto desse preconceito: com grande frequência, ciclistas são obrigados aceder seu lugar de direito na via para que os automóveis passem. Enrico estabelece um paralelo entre a história de Rosa Parks (veja abaixo) e a perseguição institucional ao movimento Massa Crítica. Mas o preconceito vai muito além.

Muitos motoristas nos obrigam, com o tamanho e a periculosidade de seus carros e som insistente de suas buzinas, a literalmente sair da rua para que eles passem. Quantas vezes motoristas raivosos já não quiseram que eu evaporasse da faixa da direita da avenida, imediatamente, para que eles pudessem passar exatamente ali, mesmo quando podiam mudar de faixa para ultrapassar em segurança e sem stress? 
É uma situação que tem mais semelhanças com o que ocorreu com Rosa do que pode parecer. Acompanhe a seguir.

\section{A obrigação de ceder lugar aos brancos...}

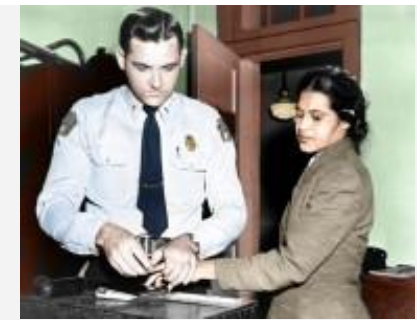

Rosa Parks sendo presa por não ceder seu lugar a um branco. Imagem: RosaParksFacts.com

Rosa Parks, uma costureira negra de 42 anos, andava de ônibus na cidade de Montgomery, no Alabama. O ano era 1955, época em que o preconceito era vergonhosamente aberto e institucionalizado naquela região dos Estados Unidos. Havia locais que negros não podiam frequentar, banheiros que não podiam usar, serviços que eram prestados exclusivamente a brancos, locais com espaço demarcado para negros. E ambientes onde a preferência era sempre dos brancos presentes, como por exemplo o interior dos ônibus.

Negros deveriam entrar pela porta de trás e sentar-se no fundo. Se todos os assentos do ônibus ficassem ocupados, os negros deveriam se levantar para dar lugar aos brancos que embarcavam pela porta da frente.

Os negros eram obrigados a abrir mão de seus direitos em favorecimento dos brancos.

Com os assentos todos ocupados e alguns brancos já em pé, o motorista levantou-se para fazer com que os negros cedessem lugar. Rosa Parks era uma das pessoas sentadas. Um rapaz ao seu lado se levantou, mas tudo que ela fez foi passar para o assento junto à janela. O motorista ameaçou chamar a polícia, mas Rosa continuou irredutível, dizendo que não sentia que devesse fazer aquilo. "Eu sabia que alguém tinha que dar o primeiro passo e eu estava determinada a não sair dali. A maneira como éramos tratados não era certa e eu estava cansada disso", contou Rosa mais tarde, em sua autobiografia.

Apesar da lei vigente dizer que o condutor do veículo poderia estipular assentos de acordo com as características étnicas, ela não obrigava negros a cederem lugar aos brancos. Ainda assim, Rosa Parks foi presa.

\section{... e a obrigação de ceder lugar aos carros}

\section{Código de Trânsito Brasileiro}

Art. 29, § 20: Respeitadas as normas de circulação e conduta estabelecidas neste artigo, em ordem decrescente, os veículos de maior porte serão sempre responsáveis pela segurança dos menores, os motorizados pelos não motorizados e, juntos, pela incolumidade dos pedestres.

Art. 58: Nas vias urbanas e nas rurais de pista dupla, a circulação de bicicletas deverá ocorrer, quando não houver ciclovia, ciclofaixa, ou acostamento, ou quando não for possível a utilização destes, nos bordos da pista de rolamento, no mesmo sentido de circulação regulamentado para a via, com preferência sobre os 
Embora o Código Brasileiro de Trânsito garanta o direito de circulação das bicicletas nas ruas e estradas e a prioridade das bicicletas em relação aos automóveis, muitos motoristas ainda acreditam que a bicicleta deve sempre ceder passagem ao automóvel. Deve sair de sua frente, desaparecer, evaporar dali instantaneamente, liberando o espaço que lhe é de direito para o carro passar. Como o negro que deveria se levantar para que o branco se sentasse.

O resultado disso são as chamadas "finas educativas", quando motoristas passam propositalmente perto de ciclistas que não cedem seu lugar na via, colocando em risco sua vida a fim de ensiná-los a se comportar direito perto de um carro. Finas educativas foram responsáveis pelas mortes de Márcia Prado, Antônio Bertolucci e muitos outros anônimos.

Há também aqueles que buzinam insistentemente atrás do ciclista, ameaçando passar com o carro em cima caso você não abdique do seu direito de circulação e de sua prioridade no uso da via para alguém que, muitas vezes, nem com pressa está. Saia da frente, um motorista quer passar.

E há, lamentavelmente, aqueles que abrem caminho à força, como o atropelador de ciclistas Ricardo Neis, que não se conformou quando percebeu que a multidão de ciclistas à sua frente não cederia seu lugar de direito para que ele passasse com seu carro. Neis abriu caminho à força em meio a centenas de pessoas, atirando gente para todos os lados e ferindo 17 dos malditos ciclistas que se recusaram a ceder seu lugar.

Os ciclistas são obrigados, em muitas situações, a abrir mão de seus direitos em favorecimento de quem está em um carro.

A lei garante não só o direito dos ciclistas como também punições para motoristas que colocarem ciclistas em risco. Em São Paulo, motoristas passaram a ser multados por desrespeito ao ciclista em 2012, mas a fiscalização ainda é sutil e, em outras cidades, raramente acontece. E essa sensação de impunidade contribui para que as ameaças à vida continuem.

\section{Ciclistas sinalizam pontes com placas de compartilhamento em São Paulo}

B RACHEL SCHEIN | ÚLTIMA ATUALIZACCÃO EM 3 DE DEZEMBRO DE 2013

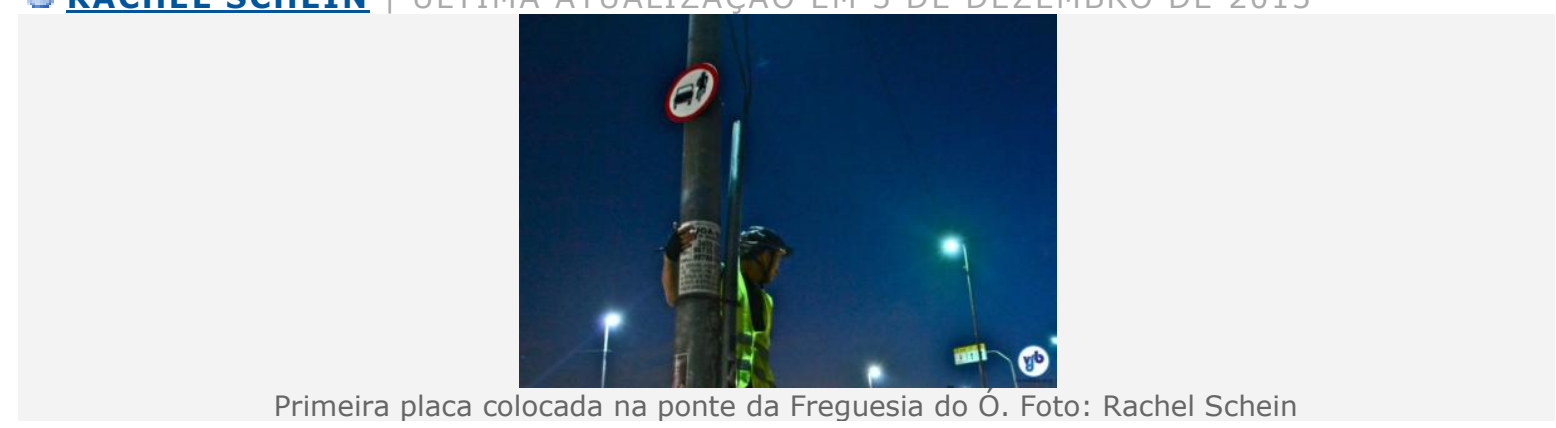

A Ciclo ZN , organização criada pelos ciclistas da Zona Norte, vem fazendo uma série de ações para chamar a atenção do poder público para a segurança dos ciclistas nas 
pontes. Depois da Bicicletada das Pontes em setembro, que resultou na pintura de faixas e bicicletinhas na ponte das Bandeiras, e de sinalizar da mesma forma a ponte do Pacaembu na semana seguinte, o grupo instalou placas de compartilhamento na Freguesia do Ó, Piqueri, Limão e Casa Verde.

Segundo Roberson Miguel, a intenção era fazer a sinalização em todas as pontes da Zona Norte, mas como a placa ficou um pouco menor do que se esperava, preferiu-se colocar mais placas em menos pontes. A solução encontrada pelos ciclistas foi simples e barata: discos de vinil foram usados para a confecção das placas, pintados com tinta spray.

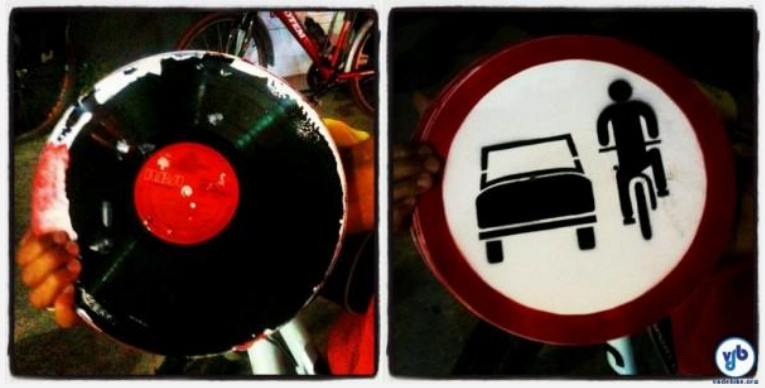

Discos de vinil foram utilizados na confecção das placas. Foto: Rachel Schein

Assista ao vídeo da ação:

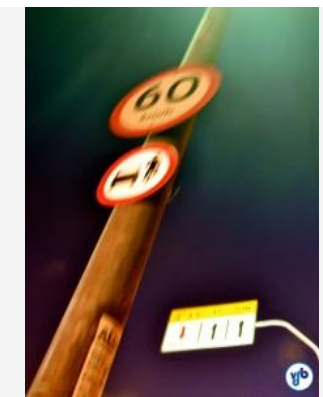

A velocidade de $60 \mathrm{~km} / \mathrm{h}$ nas pontes (por sinal, muito alta) é frequentemente desrespeitada. Foto: Rachel Schein 


\section{BICICRETEIRO -}

\section{Fazendo uma limonada - Monotrilho e a Ciclovia da Marginal Pinheiros} por André Pasqualini

30 de outubro de 2013

Vou tentar escrever um post mais técnico explicando o porque graças a obra do Monotrilho da linha Ouro do Metrô é que iremos ganhar uma Ciclovia de 8 quilômetros e mais dois acessos a Ciclovia da Marginal Pinheiros. No final do texto farei uma coletânea de posts interessantes sobre o mesmo assunto.

\section{Obras do Monotrilho e impactos no funcionamento da Ciclovia}

No final de setembro de 2013 surgiu a notícia que, devido ao avanço das obras do Monotrilho que chegaram a Marginal Pinheiros, como o trajeto do mesmo passaria por sobre a Ciclovia, desde a Ponte Estaiada, até a Estação Granja Julieta, por questões de segurança o acesso a Ciclovia, nesse trecho, seria interrompido por dois anos.

Essa decisão causou um rebuliço enorme entre os ciclistas que rapidamente organizaram uma manifestação de protesto. Ao saber disso a Secretaria de Transportes Metropolitanos suspendeu a interdição e imediatamente convocou diversos ciclistas e entidades para discutirem alternativas a interdição total da ciclovia mesmo durante a obra. Eu fui um dos convidados para essas reuniões.

A primeira reunião aconteceu no dia 03 de outubro de 2013, nela técnicos do Metro e do consórcio responsável pela obra simplesmente não sabiam o que fazer para resolver a questão, mas que estavam abertos a soluções. Nesse momento percebi a oportunidade de fazer uma limonada com esse limão azedo. Mostrei a todos presentes um post publicado em meu blog em Fevereiro de 2012 onde cito várias sugestões para melhorarmos a Ciclovia e a partir de então surgiram as sugestões que resumo logo abaixo:

\section{Sugestões apresentadas para não interromper o tráfego de ciclistas na Ciclovia}

O complexo viário da João Dias tem 3 pontes, dei a sugestão deles usarem a ponte antiga, hoje usada como uma via de acesso (exclusiva para os carros) a pista expressa da Marginal Pinheiros (sentido Castelo), construindo uma rampa ou uma escada para o ciclista chegar até a ponte. A partir dali ele poderia atravessar o rio e acessar a margem oeste, onde seria construída uma nova Ciclovia nessa margem, sobre uma pista de terra já consolidada, sem a necessidade de fazer grandes obras. 


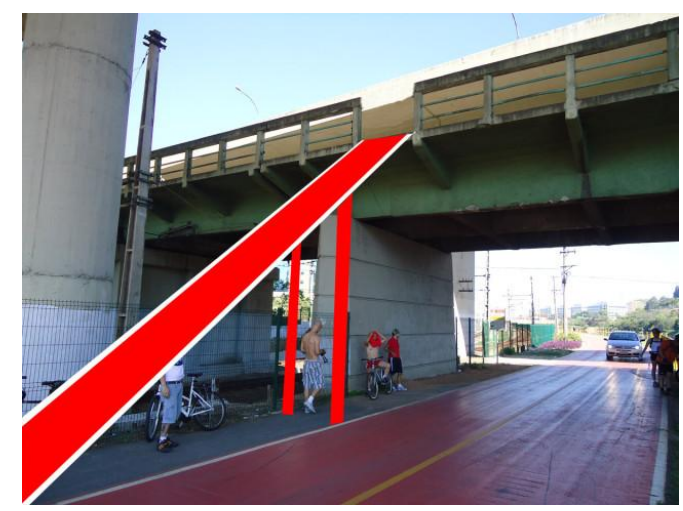

Já na margem oeste, o ciclista seguiria até a Usina da Traição, como a passagem do ciclista pelo meio da usina seria algo complexo, dei a sugestão da construção de uma travessia sobre o Rio Pinheiros de madeira assim o ciclista poderia voltar a margem leste do Rio Pinheiros e sair da ciclovia pelo acesso da Vila Olímpia. Como eles teriam que criar uma solução imediata teria que ser em curtíssimo prazo, sugeri que eles construíssem uma ponte flutuante sobre o Rio Pinheiros, pelo menos até concluírem uma obra mais complexa de travessia sobre o Rio.

Caso eles aceitassem nossas sugestões, além de ganharmos uma nova Ciclovia de 6 quilômetros na outra margem do Rio Pinheiros, poderíamos usar a Ponte João Dias como mais um acesso a Ciclovia, pois hoje há uma forma tosca, mas segura, do ciclista acessar aquele pontilhão da foto acima. Em breve publicarei um novo post falando sobre a Ciclovia da Carlos Caldeira Filho onde detalharei melhor a questão desse acesso.

\section{A proposta final do Metro para resolver o conflito dos ciclistas com a obra do Monotrilho}

Depois dessa primeira reunião realizamos diversos contatos com a equipe do Metro onde discutimos várias possibilidades, até que no dia 30 de outubro de 2013 fomos convocados para a apresentação da solução final que o Metro irá adotar, abaixo segue o detalhamento.

\section{Uso da Ponte João Dias para o ciclista transpor o Rio Pinheiros}

O Metro considerou essa minha sugestão de usar a Ponte João Dias, junto a margem leste (onde está a atual Ciclovia), construirão uma escada de ferro com canaletas para que o ciclista consiga subir até a ponte. Prometeram também nos consultar antes de começarem a projetar essa escada, assim poderemos indicar a melhor forma de fazê-la, de modo que facilite o acesso do ciclista sem maiores riscos para o mesmo. 


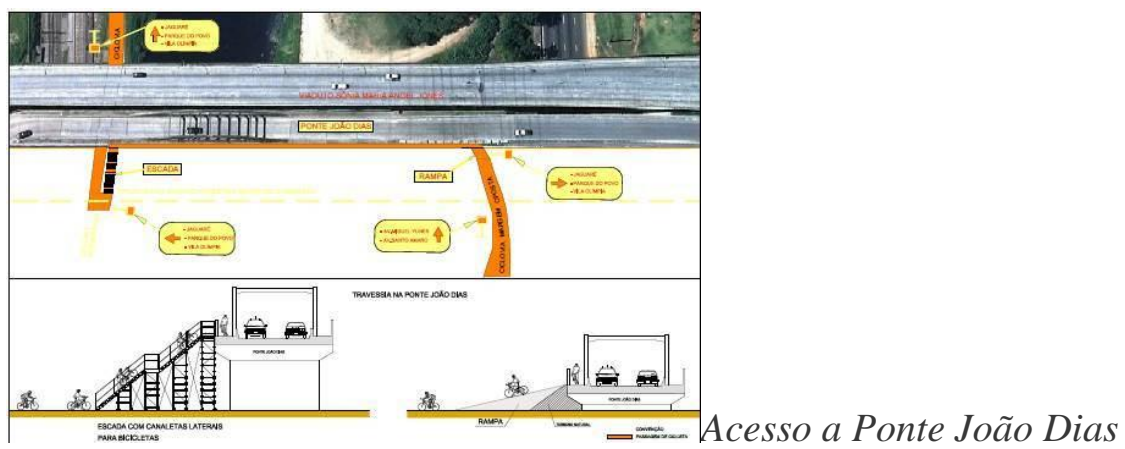

Já na margem oeste não será necessário fazer uma escada, lá há espaço suficiente para fazer um acesso em rampa.

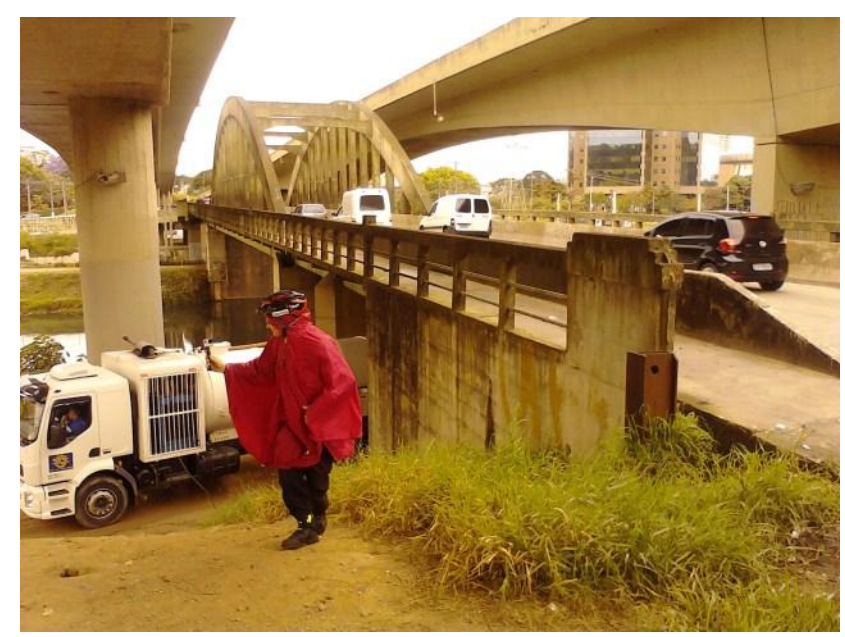

Pontos negativos: Não é apenas negativo mas principalmente bizarro, segundo o consórcio, a CET-SP condicionou a aprovação do uso da ponte João Dias a construção de um muro que impeça o ciclista de acessarem a Ciclovia. Ou seja, ao invés da Prefeitura aproveitar a situação e consolidar um novo acesso ela criou mais dificuldades aos ciclistas. Como o assunto é mais complexo, devo marcar uma conversa com a Prefeitura o quanto antes para escrever um post sobre o assunto e detalhar melhor essa questão.

Pontos positivos: Essa solução mostrará que há viabilidade na construção de acessos a ciclovia utilizando as atuais pontes, algo que sempre foi rejeitado pela CET-SP. Vamos ver se até a conclusão da obra a gente faça com que não seja construído esse muro para que a gente possa dizer que o outro ponto positivo é justamente o novo acesso a Ciclovia junto a ponte João Dias. 


\section{BIKEANJO}

Quero ser um Bike Anjo!

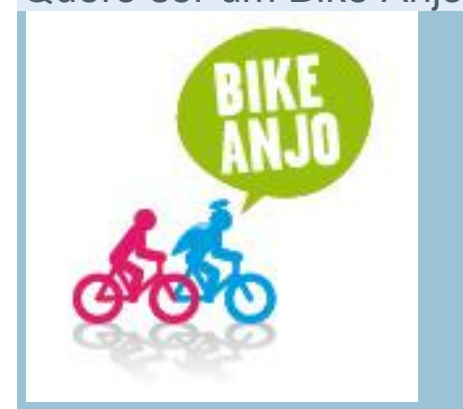

Junte-se a nós e faça parte dessa rede incrível de voluntários por todo o Brasil que querem buscar uma cidade melhor.

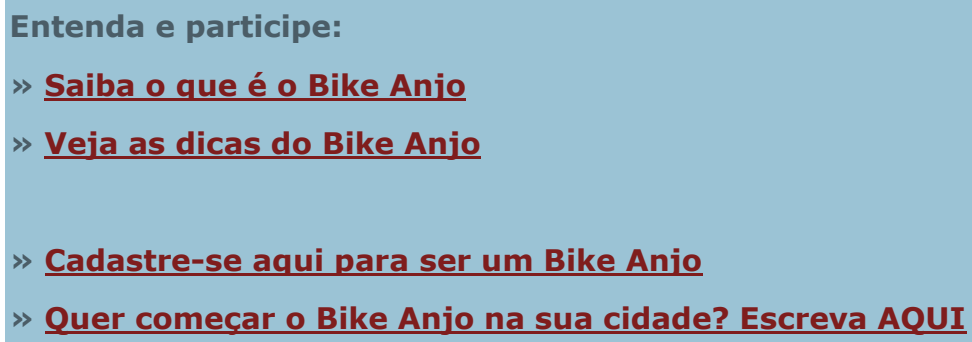

Mas se você ainda está em dúvida de como é ser um Bike Anjo, aqui vai uma curta historinha que pode te ajudar:

Agora, é sempre bom reforçar também o que NÃO se deve fazer como Bike Anjo:

1. Ser agressivo no trânsito (dê o exemplo para o ciclista iniciante. Seja um agente de mudança!)

2. Colocar o ciclista iniciante em risco ou forçá-lo a qualquer situação que não deseje

3. Colocar um pedestre em risco de qualquer forma

$\mathrm{O}=\mathrm{D}$

Compartilhe:

- $\quad$ Facebook219

- $\quad$ Twitter7

- Email 


\section{ONG Ciclocidade -}

\section{Apoio Institucional}

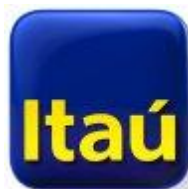

\section{RSS Ciclocidade}

\section{Plano Diretor - etapa final no Legislativo e manifesto pelo Direito à Cidade}

\section{Escrito por Thiago}

\section{Sex, 20 de Dezembro de 2013 10:50}

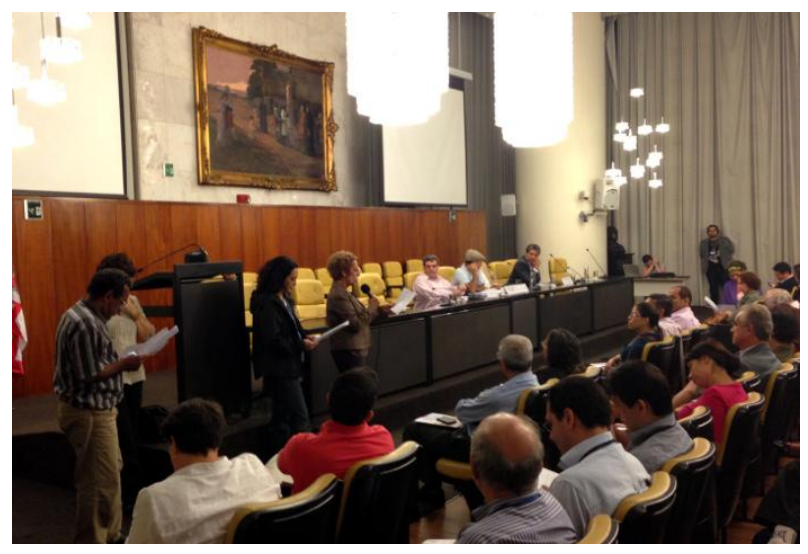

Aconteceu ontem (19/12) na Câmara dos Vereadores a última audiência do processo de debates sobre o Plano DiretorEstratégico de São Paulo. A Ciclocidade protocolou mais algumas contribuições para o PL 688/2013 (leia ao final da notícia) e participou da entrega de um documento sobre o Direito à Cidade, assinado por 47 organizações.

Com esta audiência, o processo de debates no Legislativo foi encerrado, mas o prazo para as contribuições dos cidadãos pela internet foi adiado até o próximo dia 12 de janeiro. As sugestões de alterações no texto podem ser feitas pelo sitehttp://planodiretor.camara.sp.gov.br

A proposta de Plano Diretor foi discutida inicialmente pelo Executivo municipal, que promoveu audiências públicas e aceitou contribuições da sociedade durante o primeiro semestre de 2013. Em agosto a proposta foi enviada à Câmara, que promoveu mais uma rodada de debates.

A Ciclocidade participou deste processo, enviando contribuições, estimulando a participação, produzindo informações e marcando presença nas audiências. Na reta final, também participamos de debates com organizações que atuam em outras áreas e 
este esforço resultou no Manifesto Pelo Direito à Cidade no Plano Diretor. O documento está aberto para assinaturas de entidades e cidadãos.

O Plano Diretor ainda não é ideal no tratamento da questão cicloviária, mas alguns avanços foram conquistados. Seguimos trabalhando para tornar mais curto o longo caminho de inclusão definitiva da mobilidade inteligente nas políticas públicas de São Paulo.

+ Conheça e assine o manifesto Pelo Direito à Cidade no Plano Diretor

+ Notícia no site da Câmara sobre a última audiência pública

$+\underline{\text { Site para contribuições virtuais dos cidadãos }}$

Documento com contribuições para a mobilidade humana protocolado pela Ciclocidade em 19/12:

São Paulo, 19 de dezembro de 2013

À Comissão de Política Urbana, Metropolitana e Meio Ambiente,

\section{Contribuições ao PL 688/2013 - Plano Diretor Estratégico - Mobilidade Humana}

Com o intenção de contribuir com o debate sobre o planejamento urbano de São Paulo e garantir a melhoria das condições de mobilidade na cidade, apresentamos nossas considerações sobre o PL 688/2013 e propostas de alteração, supressão ou inclusão de artigos que tratam da mobilidade urbana, em especial os artigos que tratam de pedestres e ciclistas.

\section{Art 70}

- parágrafo único, inciso I e II - Não considera estacionamentos de veículos ou postos de abastecimento como solo subutilizado, tornando possível que tais estabelecimentos utilizem terrenos centrais substituindo outros que possam cumprir mais plenamente a função social;

- Proposta: considerar estacionamentos de veículos e postos de abastecimento como solo subutilizado

\section{Art 176}

- Sistema de Circulação de Pedestres consta do PDE como componente do Sistema de Mobilidade (art. 176), mas não há nenhuma seção que descreva sua estruturação ou as ações prioritárias para esse sistema;

- Proposta: estruturar compenentes e ações prioritárias para o Sistema de Circulação de Pedestres

\section{Artigo 178 e 179}

- o 178 classifica os tipos de via (estruturais, em três tipos, e não-estruturais), abrindo brecha pra uma restrição às bicicletas em avenidas estipulada no artigo 179

- $\quad$ no 178 classifica-se "ciclovia" como "via não estrutural".

- ciclovia não é estrutural nem não estrutural, é parte da via (seja ela estrutural ou não)

- O artigo 179 (§ 2) diz "ciclovias, ciclofaixas, ciclorrotas e bicicletários somente poderão se utilizar das vias estruturais quando consideradas as condições de segurança necessárias em função da velocidade e volume de tráfego de cada via".Não são as ciclovias que se utilizam das vias estruturais, são as bicicletas. 
- Com isso, o artigo 179 condiciona o uso de vias estruturais por bicicletas às condições dos motorizados (fluxo e velocidade). O correto seria o contrário: adaptar as condições dos motorizados ao fluxo humano, especialmente nas vias estruturais N3 (de "ligação entre distritos, bairros e centralidades" - ou seja, todas as avenidas de SP)

- Propostas:

- remover o item III do parágrafo 20 no artigo 178

- alterar a redação do 179 para "As vias estruturais RECEBERÃO ADAPTAÇÕES necessárias para atender a circulação de ciclistas através da implantação de infraestrutura cicloviária adequada"

- remover o IV, (vias) "de circulação de pedestres".

\section{Art 194}

- Não especifica quais são as formas de integração entre o transporte coletivo e os nãomotorizados.

- Fala apenas de adaptações para intermodalidade em novos corredores e terminais. Deveria propor também nos existentes (especialmente terminais)

- No $\S 1^{\circ}$, determina que a construção de estacionamentos públicos seja realizada PREFERENCIALMENTE próximo à transporte coletivo público, deixando brechas para outros investimentos que utilizam recursos públicos para estímulo ao transporte motorizado (mais vagas $=$ mais carros $)$

\section{- Propostas:}

- no § 3, inciso III - "integração com outros modos de transporte, em especial os nãomotorizados", adicionar "através de implementação de bicicletários, priorização de travessias de pedestre, permissão de embarque de bicicletas em veículos do sistema e outras"

- Adicionar algum artigo ou inciso que fale sobre a adaptação dos atuais terminais e bicicletários também, e não apenas os novos.

- No $\S 1^{\circ}$, determinar que a cosntrução de estacionamentos públicos seja feita EXCLUSIVAMENTE próximo à transporte coletivo, com previsão de exceções taxativas (ex.: hospitais);

\section{Artigos 114 a 118}

- Para os Planos Regionais das Subprefeituras (art. 114 a 117) há pouco detalhamento do conteúdo mínimo a ser desenvolvido e não há indicação de planejamento de Sistema de Mobilidade como conteúdo mínimo, sendo mais crítica a ausência de planejamento para não motorizados;

- $\mathrm{O}$ art. 116 indica que os Planos Regionais das Subprefeituras deverão articular-se com os Planos de Desenvolvimento dos Bairros. É importante que os planos estejam articulados entre si, mas o Plano de Bairro deveria ser um detalhamento do Plano Regional, pois caso contrário, os Planos Regionais podem se tornar "colchas de retalho" do planejamento local;

- Para os Planos de Desenvolvimento de Bairro (art. 118) apesar de apresentar bastante detalhamento sobre seu conteúdo mínimo, apresenta algumas falhas: (1) não há indicação de órgão responsável pela sua elaboração, deixando esse plano demasiadamente solto do contexto institucional de planejamento; (2) apresenta conteúdo altamente técnico, reforçando a necessidade de apoio técnico para sua elaboração; (3) há indicação da necessidade de planejar um Sistema Cicloviário que, sem o planejamento no nível regional, perde o caráter sistêmico de conexão com o restante da cidade, podendo ficar resumido à 
acessibilidade local; (4) não prevê a elaboração de um planejamento do Sistema de Circulação de Pedestres;

\section{Art 240}

- Não há previsão de destinação de recursos do FUNDURB para a implantação de infraestrutura cicloviária, gestão ou manutenção do sistema cicloviário.

- Proposta: inserir entre os destinatários de recursos do FUNDURB a implantação de infraestrutura cicloviária, gestão ou manutenção do sistema cicloviário.

\section{Ausência de indicativo para rede cicloviária estrutural (vários artigos)}

- O projeto contempla apenas ações estratégicas de sistema cicloviário integrada ao sistema de transporte coletivo, postergando para o Plano de Mobilidade e para os Planos Regionais e de bairro (ver acima artigos 114 a 118) todas as demais definições.

- Proposta: contemplar, ao menos como princípio, a criação de uma rede cicloviária estrutural na cidade e/ou tratar de questões estruturantes para pedestres e ciclistas como a travessia das pontes dos rios Pinheiros e Tietê ou a redução das velocidades máximas em ruas e avenidas através da adequação da infraestrutura viária.

\section{Políticas de estacionamento de veículos motorizados (vários artigos)}

- Falta ação específica ou diretriz para a gestão da política de estacionamentos na cidade. É mencionada apenas a gestão do estacionamento na região central.

- Proposta: considerar diretriz de restrição de estacionamento em via pública como política de desestímulo ao uso do automóvel ;

- O PDE deveria extinguir o conceito de mínimo obrigatório de vagas ou área de estacionamento privado em empreendimentos/estabelecimentos;

- Idealmente definir ou indicar que deve ser definido máximo de oferta de estaciona- mento privado em empreendimentos/estabelecimentos;

- Não há previsão de limitação de oferta de vagas de estacionamento, somente a partir da segunda vaga são incluidas na área computável e somente nos eixos (art. 31 - deixa para ser definido pelo zoneamento). É necessário que seja excluído a exigência de mínimo de vagas de estacionamento, que seja proposto máximo de vagas independentemente do local da cidade e que a oferta de vagas ou área de estacionamento ao longo dos Eixos de Transformação Urbana seja severamente restrita ou, idealmente, proibida;

\section{Gestão e Financiamento}

\section{ESCOLA DE BICICLETA}




\section{capítulo 4. pedalar no trânsito}

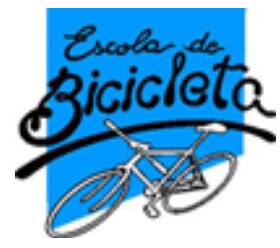

Trânsito: carros e mais carros, ônibus, motociclistas apressados, pedestres. E nós, ciclistas. Como é que a gente faz?

Pedalar no trânsito parece impossível para muitos, principalmente para quem mora em cidade grande. Será mesmo? Se isto é verdade, por que tem aumentado o número de ciclistas nas ruas?

O que é verdade ou imaginação sobre segurança no trânsito? Segurança no trânsito é estabelecida a partir de números, estatísticas, encontrados através de pesquisas realizadas com base científica, que dizem de fato o que é seguro, perigoso ou inseguro para o condutor de um veículo, pedestre ou qualquer outro que esteja participando do trânsito. O resto é imaginação (ou ficção) popular, e esta sim, costuma ser perigosa.

Normalmente, quando acontece um acidente a história corre de boca em boca, e em pouco tempo parecerá que houve um acidente em cada esquina e a cada minuto. Há um certo prazer em contar e ouvir histórias deste tipo. Mesmo depois de muito tempo, um acidente sempre é uma conversa interessante. O que foi um tombo causado por um susto acaba se transformando num coitado sob as rodas de um ônibus. É como no caso dos aviões: há em média 2 (sim, dois!) acidentes para cada milhão de decolagens, o que transforma o avião no meio de transporte mais seguro existente. Mesmo assim só se fala nos que se esborracharam. Detalhe: nestes dois raríssimos acidentes não necessariamente houve morte, nem um arranhão sequer (o avião apenas pousou de barriga).

A imensa maioria dos ciclistas pedala sem sofrer acidentes de trânsito! Mas, bom mesmo é quando há sangue na conversa. O fato é que as pessoas se apegam a certas verdades muito mais para evitar a possibilidade de mudanças em suas vidas do que para qualquer outra coisa. "Vai que pedalar é muito mais seguro que imagino, eu vou ter que assumir que estava errado todo este tempo".

O que é novo é estranho e traz receios. Para quem pedala pela primeira vez no trânsito a situação pode parecer assustadora. Só nos conscientizamos que a maioria dos perigos são imaginários com a convivência, a prática.

Trânsito é previsível, tem lógica, responde à física. Há uma parte psicológica? Sim, mas esta também é previsível. Todo acidente é causado por um erro, uma falha. Se não houver erro ou falhas, não haverá acidente. É óbvio, parece uma afirmação besta, idiota, mas não é, muito pelo contrário. Quem compreende esta verdade, entende o que é segurança no trânsito e praticamente zera a possibilidade de um acidente.

Antes de culpar o outro, descubra qual é seu erro e você descobrirá a 


\section{solução para o conflito.}

\section{Para o ciclista em qualquer lugar:}

1. seja educado

2. obedeça as leis de trânsito

3. sempre sinalize suas intenções

4. use roupas claras ou chamativas

5. mantenha os refletores limpos

6. evite ruas e avenidas movimentadas

7. mantenha-se à direita e na mão de direção

8. não faça zig-zag: procure pedalar mantendo uma linha reta

9. aprenda a ouvir o trânsito

\section{pedalar com segurança}

Se o ciclista seguir umas poucas regras básicas o risco de acidente cai praticamente a zero. Sempre haverá possibilidade de alguma tensão ou conflito, mas será bem mais difícil a ocorrência de um acidente.

O importante é você entender que, enquanto pedala e conduz a bicicleta, você é um ciclista, e não um motorista ou motociclista. Bicicleta acelera, mantém a velocidade e desacelera de uma maneira completamente diferente de qualquer veículo motorizado. Por causa disto a relação do ciclista com o trânsito tem suas particularidades que tem ser respeitadas.

Mais da metade dos acidentes de trânsito envolvendo ciclistas são responsabilidade do próprio ciclista. 


\section{Redes Sociais - Facebook}

Essa coisa de mão de direção foi inventada por quem criou os carros

há 13 horas · Curtir · 2

Um dia ainda compreenderemos a possibilidade do contrafluxo para bicicletas. E o sinal vermelho, "desrespeitado" por ciclistas do MUNDO todo, pode ser solucionado com infraestrutura q garanta cruzamentos sem conflito. Talvez devêssemos centrar nossos esforços em exigir tais soluções, em detrimento de apontar o dedo para nossos amigos q estão aí pedalando.

há 13 horas · Curtir · 3

Sou $100 \%$ a favor dos bicicleteiros...Mas, quando estou guiando,fico super nervosa quando vejo um à minha frente, de medo de machucá-lo.As vezes,dou um tempo,e espero que ele vá embora. 
ANEXO III DETALHES DA INFRAESTRUTURA CICLOVIÁRIA EXISTENTE 


\section{PARQUE ZILDA ARNS - INFRAESTRUTURA E EQUIPAMENTOS IMPLANTADOS}

- Infraestrutura de Segurança: 1 Batalhão da Policia Militar;

1 Companhia da Policia Militar;

3 Bases Comunitárias;

3 Unidades de Vigilância;

1 Central de Segurança.

- Infraestrutura de Apoio: 19 Praças de Travessia;

9 Praças Internas;

7 Sanitários Públicos;

7 Bicicletários;

23 Bebedouros;

72 Defensas Fixas;

13 Defensas Móveis.

- Equipamentos: 6 Quadras Poliesportivas;

3 Quadras Poliesportivas Cobertas;

6 Quadras de Volei;

4 Quadras de Futvolei;

2 Quadras de Futebol Mirim;

2 Campos de Futebol Meio-oficial;

2 Quadras Tabela 21;

6 Campos de Taco;

7 Campos de Bocha;

6 Campos de Malha;

8 Praças de Ginástica;

2 Arquibancadas;

1 Pista de Skate/Cross;

2 Pistas de Skate (Percurso);

2 Pistas de Skate Mirim;

2 Pistas de Cross;

3 Escaladas Horizontais;

4 Anfiteatros; 


\section{Praças de Atividade; \\ 4 Áreas de Estar - Bancos; \\ 17 Áreas de Mesas de Jogos; \\ 180 Mesas;}

15 Parquinhos Infantis;

10 Pérgulas;

10 Redários.

- Paisagismo: 3.363 Árvores;

812 Palmeiras;

$24.852 \mathrm{~m}^{2}$ forração;

$59.880 \mathrm{~m}^{2}$ Gramado;

$10.000 \mathrm{~m}^{2}$ Pedrisco área;

$200 \mathrm{~m}^{3}$ Pedrisco volume;

4 Áreas de Viveiros;

1 Área de Horta Comunitária;

1 Lago. 
2. Tabela com bicicletários existentes no Município de São Paulo e o respectivo número de vagas de acordo com informações obtidas junto ao Metrô, CPTM e SPTrans

\begin{tabular}{|c|c|c|c|c|}
\hline Estação/Terminal & Respons. & Linha & Empréstimo no bicicletas & № vagas \\
\hline Santana & \multirow[t]{19}{*}{ Metrô } & \multirow[t]{5}{*}{ Azul } & $10 *$ & $10^{*}$ \\
\hline Armênia & & & $10 *$ & $10 *$ \\
\hline Liberdade & & & $10 *$ & $10 *$ \\
\hline Paraíso & & & $10^{*}$ & $20 *$ \\
\hline V. Mariana & & & $10^{*}$ & $10^{*}$ \\
\hline V. Madalena & & \multirow[t]{3}{*}{ Verde } & $10^{*}$ & $05 *$ \\
\hline Tamanduateí & & & \multirow[t]{2}{*}{ Não } & \\
\hline V. Prudente & & & & \\
\hline Corínth.-Itaquera & & \multirow[t]{9}{*}{ Vermelha } & $15 *$ & $132 *$ \\
\hline Guilh. Esperança & & & $20 *$ & 116 \\
\hline Carrão & & & $10^{*}$ & $137^{*}$ \\
\hline Brás & & & $11^{*}$ & $10^{*}$ \\
\hline Sé & & & $10^{*}$ & $10^{*}$ \\
\hline Anhangabaú & & & $10 *$ & 10 \\
\hline Santa Cecília & & & $10^{*}$ & $10^{*}$ \\
\hline Marechal Deodoro & & & $10^{*}$ & $10^{*}$ \\
\hline Palm.-Barra Funda & & & $8 *$ & 10 \\
\hline Butantã & & Amarela & 10 & 86 \\
\hline Pinheiros & & & \multirow{32}{*}{ Não } & 126 \\
\hline Ceasa & \multirow{15}{*}{ CPTM } & \multirow[t]{8}{*}{ Esmeralda } & & 144 \\
\hline VillaLobos-Jaguaré & & & & 233 \\
\hline Cidade Universitária & & & & 60 \\
\hline Vila Olímpia & & & & 94 \\
\hline Autódromo & & & & 261 \\
\hline Jurubatuba & & & & 262 \\
\hline Primavera-Interlagos & & & & 226 \\
\hline Grajaú & & & & 178 \\
\hline Tamanduateí & & Turquesa & & 164 \\
\hline Comend. Ermelino & & \multirow[t]{6}{*}{ Safira } & & 196 \\
\hline Itaim Paulista & & & & 256 \\
\hline Jd.Helena-V. Mara & & & & 256 \\
\hline S. Miguel & & & & 33 (paraciclo) \\
\hline Jd. Romano & & & & 240 \\
\hline USP Leste & & & & 270 \\
\hline Jabaquara & \multirow{2}{*}{\multicolumn{2}{|c|}{ EMTU }} & & 225 \\
\hline S. Mateus & & & & 110 \\
\hline Guarapiranga & \multirow{14}{*}{\multicolumn{2}{|c|}{ SPTrans }} & & 7 \\
\hline V. N. Cachoeirinha & & & & 25 \\
\hline Pirituba & & & & 21 \\
\hline Campo Limpo & & & & 50 \\
\hline Varginha & & & & 14 \\
\hline Mercado & & & & 72 \\
\hline Sacomã & & & & 146 \\
\hline Sapopemba-Teot. & & & & 42 \\
\hline Pedro II & & & & 94 \\
\hline Ana Nery & & & & 90 \\
\hline Alberto Lion & & & & 28 \\
\hline C. A. Ipiranga & & & & 66 \\
\hline N.Sra.Aparecida & & & & 46 \\
\hline R. do Grito & & & & 86 \\
\hline Total & & & 174 & 4.930 \\
\hline
\end{tabular}

Tabela 12 - Relação de bicicletários e bicicletas de aluguel nas estações e terminais de transporte do Município de S. Paulo (*) serviço temporariamente indisponível

Fonte: Sites do Metrô, CPTM, EMTU e SPTrans 


\section{Programas de integração modal com a rede metroferroviária}

\section{Programa Ciclista Cidadão da CPTM}

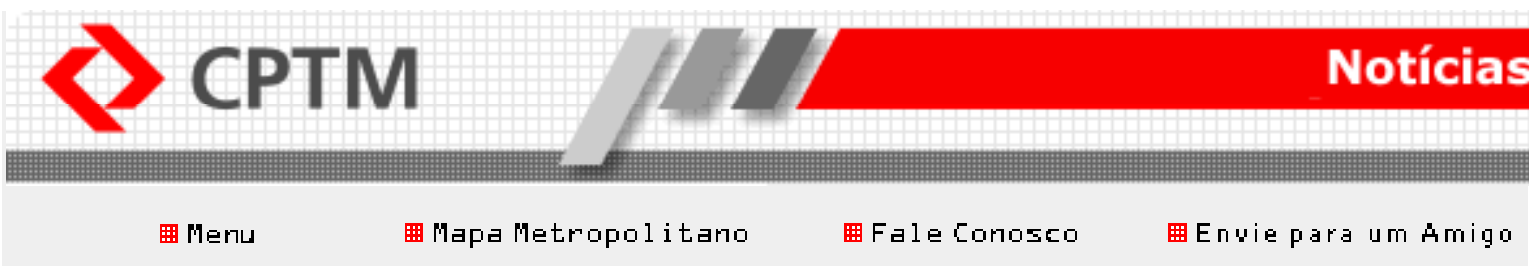

\section{Ciclista Cidadão}

Veja também
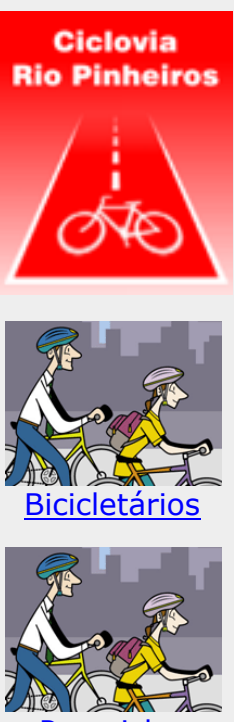

Paraciclos

\section{Siga o Regulamento:}

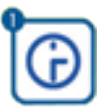

Sábados a partir das 14h. Domingos e feriados o dia inteiro.

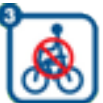

É proibido andar de bicicleta nos acessos e áreas internas das estações. Empurre a bicicleta, matendo-a sempre ao seu lado.

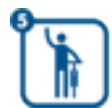

Informe a um funcionário que você está portando a bicicleta antes de validar seu bilhete, para ter sua passagem autorizada através da cancela/portão.

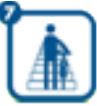

Nas escadas fixas, as bicicletas devem ser carregadas. Aguarde a liberação da escada pelos demais usuários, como medida de segurança.

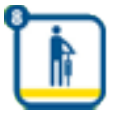

Mantenha sua bicicleta antes da faixa amarela.

Caso não consiga embarcar, aguarde o próximo trem.

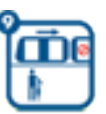

Embarque somente no último carro, sempre dando prioridade aos demais usuários.

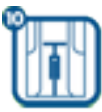

Cuide para sua bicicleta não impedir o fechamento das portas e não obstruir a entrada e saída dos usuários.

Fique distante das portas.

A bicicleta não poderá ser largada no chão, encostada na parede nem colocada sobre os bancos.

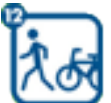

Em caso de emergência, incidente com paralização do sistema e evacuação, deixe sua bicicleta no trem.

A CPTM não se responsabiliza por sua bicicleta.

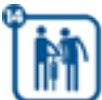

Danos causados aos demais usuários, a si próprio ou ao patrimônio dos carros e estações são de responsabilidade do ciclista.

Os funcionários poderão impedir o acesso de ciclista em casos de anormalidade no sistema ou situações de grande fluxo nas estações e trens.
São permitidas até 4 bicicletas por viagem. Caso não consiga embacar, aguarde o próximo trem.

Ligue gratuitamente para 0800055 0121, ou clique aqui para entrar em contato, e receba informações sobre os serviços da CPTM. 


\section{BICICLETA NO METRÔ}

\section{NO METRÔ SUA BICICLETA É BEM-VINDA}

Ainda nẫo é possivel usar o Metrô de bicicleta em qualquer horário, a seguir veja quando sua bicicleta é bem-vinda.

\begin{tabular}{|c|c|c|c|}
\hline \multicolumn{4}{|c|}{ HORÁRIOS } \\
\hline SEG. A SEX. & SÁbAdos & DOMINGos & FERIADos \\
\hline A partir das 20h30 & A partir das 14h00 & Durante todo 0 & Durante todo 0 \\
\hline até o último trem & até o último trem & funcionamento do & funcionamento do \\
\hline (meia noite) & $(01 \mathrm{ho0})$. & Metrô, das 04h40 à & Metrô, das 04h40 à \\
& & meia-noite. & meia-noite. \\
\hline
\end{tabular}

Obs. No máximo 04 bicicletas por trem, sempre no último vagẫo.

A bicicleta dobrável é permitida nos trens em qualquer horário, desde que esteja embalada em capaibolsa protetora e seu volume nẫo ultrapasse a medida de $150 \times 60 \times 30 \mathrm{~cm}$.

Clique aqui para ver o regulamento completo

Obs da autora: Regulamento idêntico ao da CPTM 
REFERÊNCIAS

BIBLIOGRÁFICAS 


\section{Observação importante}

A contemporaneidade do tema deste trabalho justifica a pouca disponibilidade de bibliografia a respeito por se tratar de um processo ainda em curso.

Portanto muito do que foi incluído fez parte de material de trabalho acumulado ao longo de um trajeto profissional de mais de 30 anos, dos quais quase 5 na coordenação do Departamento de Planejamento Cicloviário da Companhia de Engenharia de Tráfego de São Paulo.

Também foi utilizado como material registros divulgados pela mídia escrita, falada e eletrônica, blogs e ONGs, conversas, entrevistas informais, pesquisas de transporte, relatórios técnicos, enfim material que se coleta quando há interesse num determinado assunto.

\section{Referências Bibliográficas}

Livros, relatórios e documentos técnicos:

1. Alcântara, Adilson; Hagen, Jonas e outros "Manual de bicicletários modelo ASCOBIKE" - 2009;

2. ANTP; Associação Nacional dos Transportes Públicos : "Sistema de Informações da Mobilidade Urbana de 2007" - site da ANTP 2013

3. ANTP; Associação Nacional dos Transportes Públicos : "Sistema de Informações da Mobilidade Urbana de 2011" - site da ANTP 2013

4. Benícchio, Thiago - artigo publicado no livro "Shift Happens! Critical Mass at 20 ": “ Critical Mass is Dead. Long Live Critical Mass!” - Full Enjoyment Books, San Francisco, USA, 2012;

5. Briese, Volker - tradução: Miranda, Denir Mendes : "História das Ciclovias" - Site Transporte Ativo -- 2005

6. Companhia de Engenharia de Tráfego de SP / GST: “Fatos e Estatísticas de Trânsito em São Paulo - 2011”- São Paulo / 2012 
7. Companhia do Metropolitano de SP - Metrô : "O Uso de Bicicletas na Região Metropolitana de São Paulo" - site do Metrô / 2009;

8. Companhia do Metropolitano de SP - Metrô: "Pesquisa de Origem e Destino 2007" - site Metrô / 2007

9. Deák, Csaba; Schiffer, Suely; “A Metrópole de uma sociedade de elite” tradução Nuno Fonseca / 2007 ;

10. Deák, Csaba: “Elementos de Uma Política de Transportes para São Paulo" - Espaço e Debates / 2002;

11. Gancia, Bárbara: “A burca do talibiker” - Crônica - Revista da Folha de São Paulo - São Paulo / 2010

12. GEIPOT - Grupo Executivo de Integração da Política de Transportes "Manual de Planejamento Cicloviário" - Brasília / 2001

13. IBOPE Inteligência e Rede Nossa São Paulo: “ Tempo médio gasto no trânsito para realizar todos os deslocamentos diários/2011" São Paulo/ 2012;

14. Malatesta, Maria Ermelina Brosch, Boletim Técnico n 50: “História dos Estudos de Bicicleta em São Paulo" - Companhia de Engenharia de Tráfego, - São Paulo / 2012

15. Martins, Marco Antônio Campos, "Impasse - Brasil na Crise do Petróleo" Site IPEA-IPLAN - Brasília, agosto de 1980

16. Ministério das Cidades, Secretaria da Mobilidade Urbana - SEMOB : "Código de Trânsito Brasileiro - Lei Federal 9.503" / 1997

17. Ministério das Cidades, Secretaria da Mobilidade Urbana - SEMOB: “Lei da Mobilidade Urbana - Lei Federal 12.587 / 2012.

18. Ministério das Cidades, Secretaria da Mobilidade Urbana - SEMOB: "Caderno Bicicleta Brasil" - Brasília / 2004

19. Paiva, Carlos Eduardo; Carneiro, Edlene : “Viagens de Bicicleta no Município de São Paulo - Dados obtidos na pesquisa de origem e destino do Metrô 2007" Companhia de Engenharia de Tráfego de São Paulo / GPL / DPJ- São Paulo - 2009;

20. Pereira, Rafael Henrique Moraes; Shwanen, Tim - "Tempo de deslocamento casa-trabalho no Brasil (1992-2009): diferenças entre Regiões Metropolitanas, Níveis de Renda e Sexo" - IPEA / 2013;

21. Presada, Bill: "Cicloativismo: a expansão da bicicleta” - ANTP Associação Nacional de Transporte Público - "Caderno Técnico sobre Transporte Cicloviário" - 2007; 
22. Rolnik, Raquel; Klintowitz, Danielle: “Mobilidade na Cidade de São Paulo" Dossiê São Paulo Hoje - Estudos Avançados- São Paulo / 2011;

23. SMDU - Secretaria Municipal do Desenvolvimento Urbano: "SP 2040: a cidade que queremos" - São Paulo / 2012

24. Vasconcellos, Eduardo Alcântara: "Transporte urbano nos países em desenvolvimento: reflexões e propostas” - Annablume - São Paulo /2000;

25. Vasconcellos, Eduardo Alcântara: “ Dados de Observatorio Urbano de Movilidad Urbana” CAF / Banco de Desarollo de América Latina/2010

26. Xavier, Giselle Noceti Amon - "O Cicloativismo no Brasil e a produção da lei da Política Nacional de Mobilidade Urbana: estratégias, instituições e padrões de relação entre atores" - Universidade Federal de Sta. Catarina - Centro de Filosofia, Letras e Ciências Humanas -2007;

\section{Mídia impressa e eletrônica}

1. O Estado de São Paulo, "CPTM amplia bicicletários em estações de trem de SP” - São Paulo - edição de 26/07/2008;

2. O Estado de São Paulo -Prefeitura desativa ciclovia em Parelheiros29/03/2011;

3. Site Cidadão SP - "Usuários dos bicicletários da CPTM aprovam o serviço" 05/07/2012

4. Revista Carta Capital - SãoPaulo: “A bicicleta como meio de transporte é possível?" / 2011;

5. Revista Bicicleta "Ciclovias de São Paulo: Parque da Integração Zilda Arns, uma montanha russa de problemas" - janeiro 2013;

6. Folha de SP - "Só 4 de 17 bicicletários ainda funcionam nas estações de metrô" - 15/01/2013;

7. O Estado de São Paulo - "Bicicleta terá campanha de trânsito em SP" Caderno Cidade 23/03/2013;

8. Jornal Metro: “ Novos terminais terão bicicletários “ - 09/04/2013;

9. Folha de SP: "SP vai derrubar imóveis para fazer corredor de ônibus Secretaria pode usar Bilhete Único para emprestar bike" - 10/04/2013;

10. Folha de SP “SP testa uso do Bilhete Único no empréstimo de bicicletas" 02/05/2013; 
11. 0 Estado de SP "Cidade precisa de mais 50 mil bicicletas, diz secretário" - 03/05/13;

12. Folha de SP “Desrespeito ao ultrapassar ciclista rende só 19 multas" 04/05/2013;

13. Portal UOL - “Trânsito: Bilhete Único será integrado com o projeto Bikesampa a partir de hoje” - 06/05/2013;

14. Revista Veja SP - Bikesampa vai se expandir para a Zona Leste 24/05/2013;

15. O Estado de São Paulo - “Haddad promete transporte 24 horas e $340 \mathrm{Km}$ de vias para bikes em 2014" - 18/07/2013;

16. Folha de São Paulo: "São Paulo tem o maior trânsito da história" Caderno Cotidiano - 27/07/13;

17. Folha de São Paulo - "Ciclovias com falhas se espalham pelo país" $14 / 12 / 20013$

18. Folha de São Paulo “Isenção fiscal em dez anos equivale a $150 \mathrm{~km}$ de metrô" - 07/09/2013

19. Portal da Prefeitura do Município de São Paulo - "Prefeitura lança licitação para construção de $26,5 \mathrm{Km}$ de ciclovias na Zona Leste” $11 / 12 / 2013$

20. Portal IG Economia - "Bradesco copia Itau e lança aluguel de bicicletas em SP" - 15/12/2013

\section{Internet: Sites, Blogs e Redes Sociais}

1. Site Bikesampa - www.bikesampa.com.br

2. Site Ciclofaixa de Lazer - www.ciclofaixa.com.br

3. Site TC Urbes - www.tcurbes.com.br

4. Site CEBRAP - www.cebrap.org.br

5. Site da SPTrans - www.sptrans.com.br

6. Site Vadebike - www.vadebike.org.br

7. Site Transporte Ativo - www.ta.org.br 
8. Site PMSP - www.prefeitura.sp.gov.br

9. Site da CET - www.cetsp.com.br

10. Site Escola de Bicicleta - www.escoladebicicleta.com.br

11. Site da assembléia legislativa de SP - www.al.sp.gov.br

12. Site Bikeanjo - www.bikeanjo.com.br

13. Site Ciclocidade - www.ciclocidade.org.br

14. Facebook - www.facebook.com

15. Site Ministério das cidades - www.cidades.gov.br 
A BICICLETA NAS VIAGENS COTIDIANAS DO MUNICÍPIO DE SÃO PAULO 